В.Л. Медведев, М.Ю. Ледванов, А.Н. Курзанов, И.М. Быков

РОЛЬ ПАРАТГОРМОН-РОДСТВЕННОГО ПРОТЕИНА В РАЗВИТИИ, ФУНКЦИОНИРОВАНИИ И ПАТОЛОГИИ МОЧЕВЫДЕЛИТЕЛЬНОЙ И РЕПРОДУКТИВНОЙ СИСТЕМ

Монография 
УДК 612.018:577.112:[616.6+616 - 056.52]

ББК 28.072

P68

Aвторы:
Медведев В.Л., Ледванов М.Ю., Курзанов А.Н., Быков И.М.
Рецензенты:

Шерстнев Владимир Вячеславович - доктор медицинских наук, професcop, руководитель отдела системной нейробиологии и функциональной нейрохимии, руководитель лаборатории, заслуженный деятель науки и техники РФ, Федеральное государственное бюджетное научное учреждение «Научноисследовательский институт нормальной физиологии имени П.К. Анохина».

Ситдыкова Марина Эдуардовна - доктор медицинских наук, профессор, заведующая кафедрой урологии ФГБОУ ВО «Казанский государственный медицинский университет» МЗ РФ, заслуженный врач Республики Татарстан, заслуженный врач. РФ, член Президиума Российского общества урологов, эксперт Росздравнадзора.

Роль паратгормон-родственного протеина в развитии, функP68 ционировании и патологии мочевыделительной и репродуктивной систем: монография / В.Л. Медведев, М.Ю. Ледванов, А.Н. Курзанов, И.М. Быков. - М.: Издательский дом Академии Естествознания, 2019. - $192 \mathrm{c}$.

\section{ISBN 978-5-91327-596-7 \\ DOI 10.17513/np.376}

В монографии представлены существующие в мировой литературе современные представления о мультипотентной роли паратгормон-родственного белка (ПТГрП) в мочевыделительной и репродуктивной системах организма человека и ряда других биологических видов. Этот белок оказывает многоплановое влияние на многие физиологические и патологические процессы и, во многом, определяет сложную систему их взаимодействия. В течение трех последних десятилетий этот протеин стал предметом интенсивных исследований результаты которых составили огромный пул интереснейших фактов и чрезвычайно важных для современной биологии и медицины представлений. В монографии проанализированы современные данные об экспрессии ПТГрП и его рецептора в тканях ряда органов репродуктивной и мочевыделительной систеем. В первой главе монографии представлены результаты основных исследований практически за весь период изучения нефротропных эффектов ПТГрП в качестве фактора регулирующего развитие и функционирование почек, а также его роли в патофизиологических механизмах и патобиохимических изменениях имеющих место при экспериментальных и клинических нефропатиях, приведены существующие в литературе сведения о роли ПТГрП в формировании, функционировании и развитии патологических состояний мочевого пузыря. Во второй и третьей главах представлена информация об участии ПТГрП в физиологических реакциях и патологической трансформациии яичников, матки, предстательной железы и ряда других органов репродуктивной системы. Анализ большого массива научной литературы позволил констатировать, что в настоящее время ПТГрП рассматривается как один из ключевых регуляторов морфофункциональных, биохимических и патофизиологических процессов, связанных с различными заболеваниями мочевыделительной и репродуктивной систем организма. Практически все изложенные в монографии сведения о ПТГрП опубликованы в зарубежных изданиях. В отечественной литературе информация, посвященная этому уникальному протеину представлена единичными публикациями.

Монография предназначена для широкого круга исследователей в различных областях урологии, нефрологии, андрологии, биохимии, патофизиологии, онкологии, а также врачам-клиницистам ряда специальностей.

\section{ISBN 978-5-91327-596-7}

(C) Медведев В.Л., Ледванов М.Ю., Курзанов А.Н., Быков И.М., 2019 (C) ИД «Академия Естествознания» (c) АНО «Академия Естествознания» 


\section{ОГЛАВЛЕНИЕ}

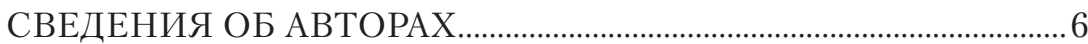

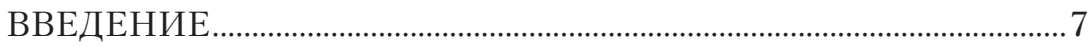

Глава 1. ПАРАТГОРМОН-РОДСТВЕННЫЙ ПРОТЕИН И ОРГАНЫ МОЧЕВЫДЕЛИТЕЛЬНОЙ СИСТЕМЫ ........9

1.1. Роль паратгормон-родственного протеина в развитии и функционировании почек, а также в патофизиологических механизмах и патобиохимических изменениях при экспериментальных и клинических нефропатиях

1.1.1. Паратгормон-родственный протеин и его рецептор в ткани почек

1.1.2. Роль паратгормон-родственного протеина

в развитии и фукционировании почек

1.1.2.1. Эффекты паратгормон-родственного протеина на рост и пролиферацию почечных структур...... 13

1.1.2.2. Влияние паратгормон-родственного протеина на экскрецию кальция и фосфора ............................. 14

1.1.2.3. Влияние паратгормон-родственного протеина на гемодинамику почек …………………………………. 16

1.1.3. Паратгормон-родственный протеин и патология почек

1.1.3.1. Паратгормон-родственный протеин при врожденных аномалиях почек и мочевыводящих путей (CAKUT)

1.1.3.2. Взаимодействие между паратгормон-родственным протеином и ангиотензином II в поврежденной почке..................................................... 28

1.1.3.3. Паратгормон-родственный протеин и тубулоинтерстициальная нефропатия ................ 29

1.1.3.4. Паратгормон-родственный протеин при токсическом поражении почек.

1.1.3.5. Ишемическое поражение почек и паратгормон-родственный белок

1.1.3.6. Паратгормон-родственный протеин при воспалении и фиброзе почек. 38

1.1.3.7. Влияние паратгормон-родственного белка на почечно-клеточный апоптоз и регенерацию почек. 46 
1.1.3.8. Паратгормон-родственный белок при хронической диабетической нефропатии..... 50

1.1.3.8.1. Паратгормон-родственный протеин при экспериментальной диабетической нефропатии ............................. 52

1.1.3.8.2. Паратгормон-родственный протеин при диабетической нефропатии человека

1.1.3.9. Рак почек и паратгормон-родственный протеин .....

1.1.4. Заключительные замечания о нефротропных эффектах паратгормон-родственного протеина

1.2. Мочеточники и паратгормон-родственный протеин ............62

1.3. Мочевой пузырь и паратгормон-родственный протеин.....63

1.3.1. Влияние паратгормон родственного протеина на гладкомышечные структуры мочевого пузыря ..............63

1.3.2. Паратгормон-родственный протеин и рак мочевого пузыря

Литература к главе 1 .74

Глава 2. ПАРАТГОРМОН-РОДСТВЕННЫЙ ПРОТЕИН И ОРГАНЫ ЖЕНСКОЙ РЕПРОДУКТИВНОЙ СИСТЕМЫ 104

2.1. Паратгормон-родственный белок в тканях матки и плаценты

2.2. Роль паратгормон-родственного белка

в модуляции локального кровотока матки

2.3. Влияние паратгормон родственного белка на функциональное состояние матки

2.3.1. Паратгормон-родственный протеин и беременность

2.4. Неоплазии матки ассоциированные с паратгормон родственным белком.

2.5. Яичники и паратгормон родственный белок 124

2.5.1. Экспрессия и физиологические эффекты паратгормон родственного белка в яичниках

2.5.2. Паратгормон родственный белок при раке яичников.

2.6. Рак вульвы ассоциированный с паратгормон родственным протеином 
Глава 3. ПАРАТГОРМОН РОДСТВЕННЫЙ БЕЛОК И ОРГАНЫ МУЖСКОЙ РЕПРОДУКТИВНОЙ СИСТЕМЫ 144

3.1. Предстательная железа и паратгормон родственный белок

3.1.1. Паратгормон родственный белок

в нормальной ткани простаты

3.1.2. Существующие факты и представления

о взаимосвязи паратгормон-родственного

протеина и рака предстательной железы

3.1.2.1. Антиапоптозный эффект

паратгормон-родственного белка при раке

предстательной железы

3.1.2.2 Роль паратгормон-родственного белка

в метастазировании рака предстательной железы.

3.1.2.3. Паратгормон-родственный белок и развитие андрогенрезистентности рака предстательной железы.

3.2. Участие паратгормон-родственного протеина

в фукционировании и онкотрансформации яичек

(семенников)

3.2.1. Физиологические эффекты

паратгормон-родственного протеина в семенниках ...... 166

3.2.2. Паратгормон-родственный

протеин-ассоциированные новообразования

в семенниках 168

3.3. Участие паратгормон-родственного протеина

в фукционировании и неопластических поражениях полового члена

3.3.1. Физиологические эффекты

паратгормон-родственного белка в пенисе 168

3.2.2. Паратгормон-родственный белок и рак полового члена 170

Литература к главе 3 172

ЗАКЛЮЧЕНИЕ 187

СОКРАЩЕНИЯ И УСЛОВНЫЕ ОБОЗНАЧЕНИЯ 188 


\section{СВЕДЕНИЯ ОБ АВТОРАХ}

Медведев Владимир Леонидович - доктор медицинских наук, профессор, заведующий кафедрой урологии ФГБОУ ВО «Кубанский государственный медицинский университет» Министерства здравоохранения Российской Федерации.

Ледванов Михаил Юрьевич - доктор медицинских наук, профессор, Президент Международной ассоциации ученых, преподавателей и специалистов.

Курзанов Анатолий Николаевич - доктор медицинских наук, профессор, профессор кафедры клинической фармакологии и функциональной диагностики и кафедры фундаментальной и клинической биохимии ФГБОУ ВО «Кубанский государственный медицинский университет» Министерства здравоохранения Российской Федерации.

Быков Илья Михайлович - доктор медицинских наук, професcop, заведующий кафедрой фундаментальной и клинической биохимии ФГБОУ ВО «Кубанский государственный медицинский университет» Министерства здравоохранения Российской Федерации, Заслуженный деятель науки России.

Авторы монографии выражают искреннюю признательность специалисту организационно-издательского отдела Кубанского государственного медицинского университета Волошину Виталию Витальевичу за помощь и содействие в подготовке и компьютерном оформлении иллюстративного материала данной книги. 


\section{ВВЕДЕНИЕ}

Предлагаемая вниманию читателей монография состоит из трех глав. Первая глава содержит анализ литературы, отражающей преимущественно систематизированные данные о роли паратгормонродственного протеина в развитии, функционировании и патологической трансформации органов мочевыделительной системы. Во второй и третьей главах представлены существующие сведения о взаимосвязи паратгормон-родственного протеина и органов женской и мужской половой системы, приведена информация об участии паратгормонродственного белка в патофизиологических и патобиохимических процессах, связанных с различными заболеваниями репродуктивной системы. Значительное место в этих главах отведено результатам экспериментальных и клинических исследований, а также описанию опубликованных в мировой литературе отдельных наблюдений, которые в основном обозначены, как «случай из медицинской практики». Целесообразность анализа сообщений о случаях редких заболеваний и в том числе новообразований, ассоциированных с гиперпродукцией паратгоромон-родственного протеина, важны для поиска ответов на многие все еще открытые вопросы клинической медицины.

Изучение белка, похожего на паратиреоидный гормон, началось в 1987 году, как кульминация 40-летнего поиска гуморального фактора, ответственного за наиболее распространенный паранеопластический синдром - гуморальную гиперкальциемию злокачественности. Почти одновременно тремя независимыми группами ученых были опубликованы результаты многолетних исследований, в которых был обнаружен, выделен и очищен до очевидной гомогенности паратгормон-подобный белок. Первое сообщение об открытии нового протеина ассоциированного с гиперкальциемией при раке молочной железы было представлено в мае 1987 года группой авторов (Burtis W.J., et al., 1987) из Йельского университета и Медицинского центра администрации ветеранов Уэст-Хейвена (Кеннектикут). В июле того же года в журнале Национальной Академии Наук США 
Moseley J.M. et al. (1987) из медицинского факультета университета Мельбурна (Австралия), опубликовали данные о выделении паратгормон-родственного белка из клеточной культуры рака легкого, а в декабре были опубликована статья (Strewler G.J. et al., 1987), представленная Медицинским центром Калифорнийского университета, департаментом фармакологии Медицинского факультета Северо-Западного университета (Чикаго, Иллинойс) и исследовательской лабораторией корпорации Мерк Шарп и Доум (Merck Sharp \& Dohme) (Вест-Пойнт, Пенсильвания) о белке обнаруженном и очищенном из клеток почечной карциномы человека, который обладал высокой $\mathrm{N}$-концевой гомологией с паратиреоидным гормоном и сходной с ним биологической активностью. Сходство этого белка по биологической активности и структуре с паратиреоидным гормоном определило его ныне существующее название - паратиреоидный гормон-родственный белок (Parathyroid hormone-related protein).

Восемь из первых 13 аминокислотных остатков паратгормон-родственного белка идентичны таковым в паратиреоидном гормоне. Биохимическое сходство подчеркивает их эволюционную взаимосвязь, вероятнее всего, обусловленную общим предком и является результатом двух раундов полного дублирования целого генома (Cardoso J.C. et al., 2014; Hwang J.I. et al., 2013). Эволюционное родство позволяет паратиреоидному гормону (ПТГ) и паратгормон-родственному белку (ПТГрП) связываться с одним общим рецептором ПТГ первого типа (PTH1R), активация которого в костной ткани индуцирует ее резорбцию с высвобождением кальция. Существенная гомология последовательности в первых 13 аминокислотных остатках ПТГ и ПТГрП отражает функциональную значимость $\mathrm{N}$-концевого домена в механизмах взаимодействия этих молекул с их общим рецептором. РTH1R высоко экспрессируется также в почках и рассматривается как основной рецептор для функций ПТГ и ПТГрП. Впоследствии было установлено, что ПТГрП продуцируется опухолевыми клетками многочисленных видов рака. Избыточная продукция опухолью и высвобождение в циркулирующую кровь ПТГрП стимулирует резорбцию кости и реабсорбцию почечного кальция и таким образом роль этого протеина в развитии злокачественной гиперкальциемии была выяснена. 


\section{Г Аава 1. ПАРАТГОРМОН-РОДСТВЕННЫЙ ПРОТЕИН И ОРГАНЫ МОЧЕВЫДЕЛИТЕЛЬНОЙ СИСТЕМЫ}

Паратиреоидный гормон-родственный белок является мультипотентной молекулой, из которой в результате протеолитического процессинга образуются более мелкие биологически активные пептиды, участвующие в регуляции выживания, пролиферации и дифференциации клеток, в различных нормальных и патологически измененных тканях. Исследованиями, проведенными за последние 30 лет учеными многих научных центров и лабораторий ведущих университетов мира, показано, что ген ПТГрП широко экспрессируется в нормальных и патологически трансформированных тканях органов мочеполовой системы, таких как матка (миометрий и эндометрий) (Ferguson J.E. et al., 1992; Williams E.D. et al., 1994; Tucci J., Beck F., 1998), почки (Strewler G.J. et al., 1987; Lee K. et al., 1996; Amizuka N. et al., 1997; Yang T. et al., 1997), плацента (Bowden S.J. et al., 1994; Emly J.F. et al., 1994), яичники (Clemens et al., 2001), мочевой пузырь (Yamamoto M. et al., 1992), половой член (Lang H. et al., 1999), яички (Czykier E., Zabel M., SurdykZasada J., 2001) и предстательная железа (Iwamura M. et al., 1994b; Cramer S. et al., 1996). Транскрипты рецептора PTH1R высоко экспрессируются в почках (Yang T. et al., 1997; Lee K. et al., 1996; Largo R. et al., 1999), мочевом пузыре (Yamamoto M. et al., 1992; Turner P.R. et al., 1998), яичнике (Watson P.H. et al., 2001), плаценте (Karperien M. et al., 1994; Curtis N.E. et al., 1998b), матке и яичках (Urena P. et al., 1993).

\section{1. Родь паратгормон-родственного протеина в развитии и функционировании почек, а также в патофизиологических механизмах и патобиохимических изменениях при экспериментадьных и кдинических нефропатиях}

\subsection{1. Паратгормон-родственный протеин и его рецептор в ткани почек}

Появление ПТГрП в ткани почек зафиксировано на ранних этапах эволюции позвоночных. Экспрессия ПТГрП впочке обнаружена у морского леща (Flanagan J.A. et al., 2000) и у пятнистой зеленой 
рыбы фугу (Canario A.V.M. et al., 2006). У личинок морского леща транскрипты ПТГрП обнаруживаются иммуногистохимически в почечных канальцах (Ingleton P.M., 2002). ПТГрП присутствует в нормальной плодной и взрослой почке млекопитающих, в которой он связывается с рецептором PTH1R (Philbrick W.M. et al., 1996; Soifer E.N. et al., 1993; Lee K. et al., 1996)

В почке экспрессия ПТГрП локализована в клубочках, проксимальных и дистальных извитых канальцах и собирающих протоках (Burton P.B.J. et al., 1992). В клетках проксимальных канальцев, клетках дистальных канальцев, собирающих эпителиальны клетках протоков и клубочковых эпителиальных клетках присутствие ПТГрП продемонстрировано иммуногистохимически в почках взрослых крыс (Soifer N.E., 1993) и в клетках того же типа в почках взрослого человека (Massfelder T. et al., 1996 b). Во взрослой почке, ПТГрП был также идентифицирован с помощью иммуногистохимии в подоцитах клубочков (Lee K. et al., 1996). Показано, что ПТГрП широко распространен во внутрипочечном артериальном русле, включая афферентные и эфферентные артериолы, плотном пятне (macula densa) и различных сегментах нефрона (Massfelder T. et al., 1996). Ранние исследования (Nickols et al., 1990) продемонстрировали наличие общих сайтов связывания для ПТГ (1-34) и ПТГрП (1-34) в почечных артериолах. ПТГрП и рецептор РТH1R экспрессируются в клетках гладких мышц сосудов, в которых ПТГрП проявляет вазорелаксантную активность (Vasavada R.C., García-Ocaña A., 1998). Культивируемые почечные гладкомышечные клетки, полученные из догломерулярных мелких артерий крыс, продолжали экспрессировать мРНК ПТГрП и белок в культуре (Endlich N. et al., 2001; Massfelder T. et al., 2001). Белок ПТГрП и мРНК также были обнаружены в коре почек (Largo R. et al., 1999), в клубочках (Yang T. et al., 1997), эндотелиальных клетках и в подоцитах, но не в гломерулярных эндотелиальных и мезангиальных клетках (Largo R. et al., 1999; Massfelder T. et al., 1996 b; Soifer E.N. et al., 1993).

Рецептор PTH1R как и ПТГрП в большом количестве присутствует в почечной паренхиме, включая внутрипочечную сосудистую сеть (Esbrit P. et al., 2001; Bosch R.J. et al., 1999). Экспрессия мРНК 
рецептора PTH1R была обнаружена в клубочках (Yang T. et al., 1997). PTH1R также экспрессируется в подоцитах и эндотелиальных клетках перитубулярных капилляров (Amizuka N. et al., 1997). С помощью микродиссекции сегментов нефрона с использованием полимеразной цепной реакции, рецептор РТН1R был обнаружен в извитых и прямых проксимальных канальцах, прямых восходящих отделах и в дистальных извитых канальцах у крысы и человека (Yang T. et al., 1997; Lee K. et al., 1996; Largo R. et al., 1999). Почечные гладкомышечные клетки и подоциты экспрессировали РТН1R в клеточной культуре (Endlich N. et al., 2001; Lee K. et al., 1996; Massfelder T. et al., 2001).

Однако in vivo экспрессия PTH1R не была обнаружена в культивируемых мезангиальных клетках (Bosch R.J. et al., 1999; Lee K. et al., 1996).

Экспрессия нескольких вариантов сплайсинга гена PTH1R во всей почке была продемонстрирована (Urena P. et al., 1993). Экспрессия peцептора PTH1R обусловлена двумя промоторами в мыши (P1 и P2) и тремя промоторами у людей (Р1-Р3), среди которых Р1 активен только в почках (Mc Cuaig K.A. et al., 1995). Кроме того, сплайсированные варианты PTH1R, лишенные сигнального пептида и первого экзона, были обнаружены в почках крыс и человека (Jobert A.S. et al., 1996; Joun H. et al., 1997). В мышечных клетках почечных сосудов и в подоцитах ген PTH1R транскрибируется исключительно с использованием почечного Р1-промотора (Amizuka N. et al., 1997; Lee et al., 1996). Таким образом, транскрипция гена PTH1R в гломеруло-сосудистой системе может регулироваться независимо от других органов.

В исследованиях Law F. et al. (1994) были изучены возможные механизмы, с помощью которых трансформирующий фактор роста-бета 1 (TGF-бета) может регулировать плотность рецепторов PTH1R в клетках почек опоссума. Уровень устойчивого состояния мРНК рецептора PTH1R при воздействии TGF-бета был зависимым от времени, при этом надир (приблизительно в 3 раза) уменьшался между 6-10 часами, что предшествовало максимальному ингибированию связывания рецептора PTH1R через 18 часов. Снижение связывания вследствие 18-часового воздействия TGF-бета было обратимым. ПТГрП-связывающая активность значительно возрастала через 
24 часа и почти полностью восстанавливалась через 48 часов. Добавление в клеточную среду монензина или циклогексимида в течение 24-часового периода предотвращало восстановление связывания ПТГрП. После удаления TGF-бета связывание рецептора PTH1R показало тенденцию к восстановлению в последующие 24 часа. Следовательно, TGF-бета представляет собой пример гетерологичной десенсибилизации рецептора PTH1R в эпителиальных клетках почек опоссума путем уменьшения экспрессии рецептора. Десенсибилизация была обратимой, и первая 24-часовая фаза восстановления зависела от синтеза и процессинга новых рецепторных белков.

При голодании увеличивалась экспрессия PTHR1 в почках (Kawane et al., 1997). Диета с высоким содержанием фосфата снижала экспрессию мРНК в почках PTHR1 (Katsumata et al., 2004). Экспрессия PTHR1 также может быть снижена при терминальной почечной недостаточности (Kuwahara et al., 2007; Urena et al., 1994). Braun K. et al. (2018) исследовали влияние физической нагрузки на почечную экспрессию ПТГрП и рецептора PTHR1 у спонтанно гипертензивных крыс. В почках гипертензивных крыс обнаружено возрастное увеличение экспрессии ПТГрП и PTHR1. Результаты этого исследования свидетельствуют о том, что физические упражнения оказывают благотворное влияние на почки гипертензивных крыс и ослабляют повышенную почечную экспрессию PTHR1 при старении. Представленные данные продемонстрировали, что усиленная физическая нагрузка связана с более низкой экспрессией PTHR1 при гипертонии и это может способствовать сохранению функции почек (Braun K. et al., 2018).

\subsection{2. Родь паратгормон-родственного протеина в развитии и фукционировании почек}

Современные знания о физиологической роли ПТГрП в почках весьма ограничены. Имеющиеся сведения демонстрируют роль этого белка в качестве фактора, регулирующего различные процессы, определяющие функционирование почек (Esbrit P. et al., 2001). В почках ПТГрП модулирует почечный кровоток и скорость клубочковой фильтрации и оказывает пролиферативное воздействие как 
на мезангиальные, так и на тубулоэпителиальные клетки клубочков (Massfelder T. et al., 1996a; Endlich N. et al., 2001; Garcia-Ocana A. et al., 1995), влияет на секрецию ренина (Saussine C. et al., 1993), экскрецию кальция и фосфора, включая дистальную канальцевую реабсорбцию кальция и фосфатный транспорт проксимальных канальцев (García-Ocaña A. et al., 1995; Esbrit P. et al., 2001; Esbrit P., Egido J., 2000; Muff R., Fischer J.A., 1992).

\subsubsection{1. Эффекты паратгормон-родственного протеина на рост и пролиферацию почечных структур}

Было показано, что ПТГрП оказывает регуляторное воздействие на рост различных типов почечных клеток. Аминоконцевые фрагменты ПТГрП in vitro являются митогенными для мезангиальных клеток крыс (Soifer N.E. et al., 1993), клеток дистальных канальцев почек собаки (de Miguel F. et al., 1991) клеток проксимальных канальцев кролика (García-Ocaña A. et al., 1995) и клеток почечной карциномы человека (Burton P.B.J. et al., 1990). В почках крысы ПТГрП, в основном обнаруживаемый в проксимальных и дистальных канальцах, стимулирует пролиферацию культивируемых мезангиальных клеток. ПТГрП увеличивает синтез ДНК в клетках проксимальных канальцев опосредованно через цАМФ и протеинкиназа С-зависимые механизмы (García-Ocaña A. et al., 1998). Хотя существующая информация свидетельствует, что ПТГрП является фактором роста первичных почечных клеток in vitro, роль системы ПТГрП в нефроногенезе in vivo во много остается недостаточно понятной. Было показано, что при развитии мезонефронов белок ПТГрП и мРНК экспрессируются в мезонефральном канале и в мезонефральных канальцах у человека (Burton P.B.J. et al., 1990; Moseley et al., 1991), а также у крысы (Campos et al., 1991). Обильная экспрессия белка ПТГрП или мРНК в системе собирательных протоков и в развивающихся канальцах доказана в развитии метанефроса. Сообщалось также о сильной экспрессии мРНК ПТГрП в развивающихся клубочках крыс. После рождения у крысы мРНК ПТГрП все еще экспрессируется в канальцах, но на гораздо более низких уровнях, в то время как это не обнаружено как в клубочках, так и в системе собирающих протоков. 
Экспрессия PTH1R также изучалась в крысиной развивающейся почке путем гибридизации in situ (Campos R.V. et al., 1991). Было показано, что при развитии мезонефронов PTH1R экспрессируется в нефрогенной бластеме, но не в вольфовом канале. Во время развития метанефроса в зрелых канальцах и клубочках зафиксирована высокая экспрессия PTH1R. С другой стороны, в нефрогенной области, а также в системе собирательных протоков, не было обнаружено никакого сигнала. Такая же картина экспрессии PTH1R сохранялась во взрослой почке, где мРНК РТН1R экспрессировалась как в трубчатых, так и в клубочковых структурах, особенно в плотном пятне, но не в системе собирающих протоков. В клубочках экспрессия рецептора выявлялась в области, соответствующей локализации подоцитов и париетальных эпителиальных клеток, но не в мезангиальные клетках. В исследовании Ауа K. et al. (1999) изучена локализация мРНК ПТГрП и РТН1R в развивающейся мышиной почке. Высокие уровни мРНК ПТГрП были найдены в собирательном канальце, уротелии и незрелых элементах клубочков. В противоположность этому, экспрессия мРНК рецептора РTH1R увеличивалась в связи с процессом созревания в развивающихся канальцах и клубочках. ПТГрП участвует в паракринной регуляции клеток проксимальных канальцев (García-Ocaña A. et al., 1995). Эти данные свидетельствуют о роли ПТГрП в развитии почек и демонстрируют, что экспрессия ПТГрП локализуется преимущественно в нефрогенной области при дифференцировке мезенхимы, тогда как РTH1R в основном локализуется в зрелых структурах, за исключением коллекторных протоков. В совокупности эти данные свидетельствуют о том, что при развитии почек ПТГрП может действовать через пути, которые возможно не включают PTH1R.

\subsubsection{2. Влияние паратгормон-родственного протеина на экскрецию кальция и фосфора}

Было показано, что ПТГрП, действуя через рецептор РTH1R, может имитировать действие ПТГ, в частности, стимулируя реабсорбцию кальция клетками почечных канальцев (Yates A.J.P. et al., 1988). Почечные эффекты ПТГрП во многом определяются стимуляцией аденилатциклазы в почечных клетках. Часть внутриклеточного цАМФ, 
поступает в просвет почечных канальцев и выделяется как нефрогенная часть мочевого цАМФ. Циклический АМФ, по-видимому, опосредуют многие из клеточных ответов на ПТГрП и в том числе фосфатурию. Этот ответ происходит с участием протеинкиназы-А, a также протеинкиназой-С опосредованной интернализацией (тип II) $\mathrm{Na}+/ \mathrm{PO}_{4}$ ко-транспортера, что приводит к снижению реабсорбции фосфата (Murer H. et al., 2003).

ПТГрП-индуцированная стимуляция реабсорбции кальция происходит преимущественно путем активного транспорта в трансцеллюлярной восходящей части петли Генле и в дистальных канальцах. Третий основной эффект ПТГрП в почках состоит в его влиянии на активность почечной 1-альфагидроксилазы. Внутривенное введение $\mathrm{N}$-концевого фрагмента ПТГрП как животным так и человеку приводит к повышению содержания в сыворотке 1,25 (OH)2D (Horiuchi N. et al., 1987). В экспериментах на хронически канюлированных зародышах овцы в течение последней пятой части беременности исследовали роль ПТГрП-(1-34) и ПТГрП-(1-141) на экскрецию с мочой кальция. Инфузия этих пептидов привела к значительному увеличению концентрации общего кальция в плазме плода, но не влияла на концентрацию в плазме или скорость экскреции фосфата с мочой. Инфузия ПТГрП-(1-34), либо ПТГрП-(1-141) также приводила к увеличению осмоляльности и рН мочи плода. Был сделан вывод о том, что ПТГрП может играть важную роль в регуляции функции почек плода (MacIsaac R.J. et al., 1993).

В экспериментах с использованием изолированной перфузированной почки крысы сравнили эффекты ПТГрП и ПТГ на почечный цАМФ и экскрецию электролита. Перфузия ПТГрП(1-34) увеличивала экскрецию цАМФ и уменьшала экскрецию кальция. Человеческий ПТГ(1-34) не вызывал значительных изменений в экскреции кальция, в то время как увеличение экскреции цАМФ было сходным с таковым при перфузии ПТГрП. При более высоких концентрациях ПТГ и ПТГрП экскреция кальция была еще более снижена в то время как экскреция фосфатов увеличилась. ПТГрП вызывал статистически значимое снижение рН мочи по сравнению с контролем. При низких и высоких концентрациях обоих гормонов рН в моче 
был ниже при перфузии ПТГрП по сравнению с ПТГ. Таким образом, ПТГрП, подобно ПТГ, действует на почки, увеличивая экскрецию цАМФ и фосфатов и снижая экскрецию кальция, но эффекты ПТГрП более выражены (Ebeling P.R. et al., 1989).

ПТГрП снижает реабсорбцию тубулярного фосфата благодаря его ПТГ-подобному ренотропному действию. Было показано, что трансформирующий фактор роста-бета (TGF-бета), значительно подавляет натрий-зависимую транспортную систему фосфата, присутствующую в апикальной мембране почечных эпителиальных клеток Взаимодействие между ПТГрП и TGF-бета и было исследовано с использованием клеточной культуры почек опоссума. Было показано, что TGF-бета ослабляет ингибирование транспорта фосфата, опосредованного ПТГрП. 18-часовая инкубация с TGF-бета привела к значительному снижению ответа цАМФ, вызванного ПТГрП. Количество сайтов связывания ПТГрП (1-34) в клетках, обработанных TGF-бета, снижалось при неизменном сродстве. Выработка цАМФ, стимулированная форсколином и простагландином E2, не был существенно изменена при воздействии TGF-бета. Следовательно, TGF-бета снижал транспорт фосфора в клетках почек опоссума, модулируя действие ПТГрП и уменьшая количество его рецепторов (Law F. et al., 1993).

Установлено, что почечная экспрессияПТГрП и экспрессия мРНК рецептора PTH1R не изменялись у крыс с овариэктомией. Однако на фоне заместительной терапии эстрогенами значительно увеличиласьэкспрессия почечной мРНК ПТГрП без очевидных изменений в экспрессии мРНК почечного рецептора РТH1R и активации аденилатциклазы. Эти данные свидетельствуют о вероятности локальной регуляция гена ПТГрП эстрогенами в почке. Полученные результаты также показали, что в почках фармакологическое действие эстрогенов может быть частично опосредовано ПТГрП (Cros M. et al., 1998)

\subsubsection{3. Влияние паратгормон-родственного протеина на гемодинамику почек}

Существующие данные подтверждают, что ПТГрП можно рассматривать как фактор регуляции морфофункционального статуса почки, который участвует в регуляции почечного кровотока и скорости 
клубочковой фильтрации, ограничивая биологическую активность сократительных стимулов в стенке артериальных сосудов почек. ПТГрП, относится к вазоактивным факторам, которые регулируют кровяное давление и почечную гемодинамикучерез изменения тонуса сосудов и секрецию ренина (Clemens T.L. et al., 2001), снижая тонус сосудов и повышая высвобождение ренина. ПТГрП экспрессируется в системной и почечной сосудистой сети. Почечная сосудистая сеть является важной мишенью для ПТГрП. То, что ПТГрП является сосудорасширяющим фактором, было впервые продемонстрировано в изолированной почечной артерии (Winquist R.J. et al., 1987) в изолированной перфузируемой почке (Musso M.J et al., 1989) и в изолированных почечных артериолах (Trizna W., Edwards R.M., 1991). C использованием модели расколотой гидронефротической почки у крыс, которая позволяет визуализировать внутрипочечные артерии in situ, было доказано, что ПТГрП (1-36) расширяет догломерулярные сосуды и увеличивает гломерулярный кровоток (Endlich K. et al., 1995). У нормальных анестезированных крыс интраренальная инфузия ПТГрП (1-36) увеличивала почечный кровоток, скорость клубочковой фильтрации и диурез. Введение ПТГрП вызывало вазодилатацию всех прегломерулярных сосудистых сегментов, в том числе афферентных артериол (Massfelder T. et al., 1996 a). Внутривенное введение ПТГрП здоровым людям в дозе, которая не влияет на системное кровяное давление и не вызывает гипотензивных эффектов, вызывало заметное (примерно на $40 \%$ ) увеличение почечного кровотока (Wolzt M. et al., 1997). Таким образом, ПТГрП (1-36) является одним из наиболее мощных почечных вазодилататоров у человека. Сообщалось, что ПТГрП (1-36) и ПТГ (1-34) индуцируют почечную вазодилатацию с аналогичной эффективностью (Endlich K. et al., 1995; Massfelder T. et al., 1996b; Musso M.J. et al., 1989; Winquist R.J. et al., 1987). Укороченные N-концевые фрагменты ПТГрП и ПТГ, являющиеся антагонистами их общего рецептора PTH1R, нивелируют реноваскулярные эффекты ПТГрП (1-36). Таким образом, ПТГрП (1-36) воздействует на почечную сосудистую сеть через PTH1R. Что касается сигнального пути PTH1R, было показано, что ПТГрП (1-36) стимулирует образование циклического АМФ в изолированных почечных микрососудах (Musso M.J. et al., 1989). 
Индуцированная ПТГрП вазодилатация почек была продемонстрирована в исследованиях на крысах и кроликах с использованием препаратов почек in vitro (Musso M.J. et al., $1989 \mathrm{a}, \mathrm{b}$ ). Было исследовано присутствие ПТГрП, в сосудистой сети почки человека и пути передачи сигнала, стимулированные во время ПТГрП-индуцированной вазодилатации почки кролика. В изолированной перфузированной почке кролика прямой ингибитор протеинкиназы ARp-cAMPS, вызывал сравнимое ингибирование ПТГрПиндуцированной вазорелаксации сосудов, предварительно суженных норадреналином. Почечная вазорелаксация и стимуляция аденилатциклазы в микрососудах почек подвергались сопоставимой десенсибилизации после воздействия ПТГрП. Ингибирование оксида азота (NO)-синтазы L-NAME, удаление NO имидазолиноксил-N-оксидом и ингибирование гуанилилциклазы метиленовым синим существенно снижало индуцируемую ПТГрП вазорелаксацию, отменяло вазорелаксацию, вызванную брадикинином, и не устраняло влияние на форсколин-индуцированную вазорелаксацию. Эффекты Rp-cAMPS и L-NAME не были аддитивными к индуцированной ПТГрП вазорелаксации. Повреждение эндотелия путем обработки почки антителом, связанным с фактором VIII, и комплементом, госсиполом или детергентом, не влияло на индуцированную ПТГрП или форсколином вазорелаксацию, но сильно уменьшало вызванную брадикинином вазорелаксацию. Напротив, повреждение эндотелия не изменяло ингибирующее действие L-NAME на вызванную ПТГрП вазорелаксацию. Исследования в изолированной перфузированной почке кролика продемонстрировали участие как циклического АМФ, так и оксида азота неэндотелиального происхождения в сосудорасширяющем действии ПТГрП (1-36) (Massfelder T. et al., 1996 b).

У нормотензивных крыс активация PTHR1 снижает реноваскулярное сопротивление. Однако у спонтанногипертензивных крыс стимуляция PTHR1 не оказывает подобного эффекта, но увеличивает пролиферацию клеток гладких мышц в этих сосудах (Massfelder et al., 2001, 2002).

Несмотря на сильные сосудорасширяющие свойства ПТГрП (1-36), его физиологическая функция в почечной сосудистой сети остается 
во многом неясной. Антагонисты PTH1R не влияли ни на исходный почечный кровоток у анестезированных крыс, ни на изолированную перфузируемую почку нормотензивных, а также гипертензивных крыс. Это указывает на то, что ПТГрП не влияет на тонус почечных сосудов в исходных условиях (Fiaschi-Taesch N.M. et al., 1998; Massfelder T. et al., 1996 a). Наблюдаемое снижение системного кровяного давления у трансгенных мышей, которые сверхэкспрессируют ПТГрП в гладких мышцах, указывает на то, что ПТГрП способен снижать сосудистое сопротивление (Maeda S. et al., 1999). Следовательно при определенных патофизиологических ситуациях внутрипочечная концентрация ПТГрП может быть достаточно высокой, чтобы вызвать почечную вазодилатацию. Известно, что несколько патофизиологических состояний сопровождаются повышенной экспрессией ПТГрП. Обнаружено, что почечная ишемия, воздействие циклоспорином и моделирование интерстициального повреждения увеличивают канальцевую продукцию ПТГрП (Garcia-Ocana A. et al., 1998; Largo R. et al., 1999; Soifer E.N. et al., 1993), который может воздействовать на соседние сосуды. Усиление экспрессии ПТГрП и длительная выживаемость после блокады ПТГрП были зарегистрированы при эндотоксическом шоке (Funk J.L. et al., 1996). Кроме того, ПТГрП может участвовать в гломерулярной гиперфильтрации при диабете и в компенсаторной гломерулярной гиперфильтрации из-за потери нефронов.

Показано, что ПТГрП (1-36) индуцирует секрецию ренина изолированной перфузируемой почкой крысы, непосредственно из юкстагломерулярных клеток (Saussine C. et al., 1993). В этих исследованиях ПТГ демонстрировал более низкую эффективность, чем ПТГрП, что ставит вопрос о том, вызывает ли ПТГрП высвобождение ренина посредством связывания сPTH1R. Сигнальный путь ПТГрП в юкстагломерулярных клетках изучен не полностью. Было доказано, что так называемый «парадокс кальция», свидетельствующий, что уменьшение, а не увеличение цитозольного кальция вызывает высвобождение ренина из юкстагломерулярных клеток, также подтвержден для процесса, индуцированного ПТГрП (Saussine C. et al., 1993). Поскольку юкстагломерулярные клетки являются миоэпителиальными клетками, допускается, что сигнальные пути ПТГрП сходны 
в юкстагломерулярных и сосудистых гладкомышечных клетках. Более того, повышенное производство циклического АМФ хорошо известно как общий внутриклеточный сигнал для секреции ренина в юкстагломерулярных клетках. Таким образом, ПТГрП может быть паракринным и/или аутокринным модулятором высвобождения ренина. Следует отметить, что клетки плотного пятна (macula densa), которые участвуют в контроле секреции ренина, как было показано, экспрессируют ПТГрП (Massfelder T. et al., 1996b; Yang T. et al., 1997). Поскольку сосудосуживающие средства и механическое напряжение активируют экспрессию ПТГрП (Hongo T. et al., 199; Noda M. et al., 1994; Pirola C.J. et al., 1993), ПТГрП может ограничивать супрессию ренина, опосредованную вазоконстрикторным и механическим воздействием. Существует гипотеза, что хронически повышенный ПТГрП косвенно увеличивает активность ренина плазмы через его анорексические эффекты, уменьшая потребление хлорида натрия (Atchison D.K. et al., 2012).

Как упоминалось выше, в физиологических условиях мезангиальные клетки не экспрессируют ни ПТГрП, ни PTH1R, a единственным источником ПТГрП в клубочках, по-видимому, являются подоциты. Однако сообщалось, что ПТГрП (1-34) оказывает расслабляющее действие на мезангиальные клетки в культуре, что, вероятно связано с цАМФ и G-белками, а также уменьшением фосфорилирования легкой цепи миозина (Bosch R.J. et al., 1999). Результаты этих исследований свидетельствуют о модулирующем влиянии ПТГрП на функцию клубочков путем противодействия эффектам вазоконстрикторных агентов на мезангиальные клетки. Более того, эти данные подтверждают мнение о том, что ПТГрП оказывает прямое релаксантное действие на мезангий, что может привести к увеличению как коэффициента клубочковой ультрафильтрации, так и скорости клубочковой фильтрации (Bosch R.J., 1999). Кроме того, мезангиальные клетки пролиферируют в ответ на ПТГрП (1-34) (Bosch R.J. et al., 1999; Soifer et al., 1993). Поскольку PTH1R не удалось обнаружить в мезангиальных клетках, было высказано предположение, что мезангиальные клетки обладают другим рецептором, взаимодействующим с ПТГрП (Bosch R.J. et al., 1999). Что касается роли ПТГрП 
в мезангиальных клетках, Largo R. et al. (1999) показали, что мезангий почек начинает экспрессировать ПТГрП на достаточно высоком уровне в экспериментальной модели тубулоинтерстициального повреждения. Таким образом ПТГрП может участвовать в мезангиальной пролиферации при гломерулосклерозе.

Подоциты экспрессируют как PTH1R, так и ПТГрП. Таким образом, ПТГрПдействует в подоцитах как аутокринный фактор. Более ранние исследования показали, что ПТГрП (1-34) стимулирует продукцию циклического АМФ в изолированных клубочках (Massfelder T. et al., 1993). Показано, что ПТГрП может активировать циклический путь AMP в подоцитахчерез PTH1R, но не увеличивает внутриклеточную концентрацию Ca2+ (Endlich N. et al., 2001). В то время как несколько условий, то есть ишемия, воздействие циклоспорином и тубуло-интерстициальные поражения почек, увеличивают экспрессию ПТГрП в канальцах, ничего не известно о стимулах, которые изменяют уровни ПТГрП в подоцитах. Исследование регионарной гемодинамики у крыс с использованием радиоактивных микросфер показало, что ПТГрП сохранял почечный кровоток, хотя артериальное давление снижалось (Roca-Cusachs A. et al., 1991). ПТГрП индуцировал вазодилатацию в изолированной перфузированной почке крысы цАМФ-зависимым путем, связанным с активацией PTH1R (Musso M.J. et al., 1989). Хотя релаксация была одинаковой in vitro на изолированных афферентных и эфферентных артериолах (Trizna W., Edwards R.M., 1991). ПТГрП увеличивал in vivo почечный кровоток и скорость клубочковой фильтрации, расширяя прегломерулярные сосуды, в то время как вазодилатация уменьшалась на эфферентной артериоле из-за сопутствующей ангиотензин II-индуцированной вазоконстрикции (Endlich K. et al., 1995; Massfelder T. et al., 1996). ПТГрП иРТН1R экспрессируются на всем протяжении внутрипочечного артериального русла. Введение экзогенного ПТГрП (1-36) увеличивает почечный кровоток и скорость клубочковой фильтрации у анестезированных крыс путем преимущественного расширения предгломерулярных сосудов (Endlich K. et al., 1995; Massfelder T. et al., 1996; Massfelder T. et al., 1996) (Massfelder T., Parekh N., 1996; Massfelder T., Stewart A.F., 1996). Кроме того, ПТГрП 
вызывает вазорелаксацию и высвобождение ренина в изолированной перфузированной почке (Musso M.J. et al., 1989; Saussine C. et al., 1993). ПТГрП стимулировал высвобождение ренина, воздействуя непосредственно на юкстагломерулярные клетки (Saussine C. et al., 1993). Культивируемые клетки гладких мышц артериальных сосудов экспрессируют как ПТГрП, так и PTH1R (Schordan E. et al., 2004). Сообщалось, что у мышей со сверхэкспрессией PTH1R имела место повышенная вазодилатация почек после увеличения объема и торможение вазоконстрикции в ответ на ангиотензин II (Noonan W.T. et al., 2003). Наконец, избыточная экспрессия PTH1R у нормотензивных и гипертензивных крыс индуцированная системной доставкой плазмиды кДНК РTH1R вызывала изменения артериального давления, тонуса почечных сосудов и активности ренина плазмы. (Fritsch S. et al., 2004; Massfelder T. et al., 2002).

Обнаружены тесные эндогенные взаимодействия, которые существуют между системой ПТГ/ПТГрП/РTH1R и ренин-ангиотензиновой системой. Установлено, что избыточная экспрессия PTH1R привела к снижению активности ренина плазмы крови. Это резко контрастирует с ранее описанным стимулирующим действием экзогенного ПТГ и ПТГрП на высвобождение ренина (Saussine C. et al., 1993). Гиперэкспрессия PTH1R у взрослых крыс глубоко изменяет реноваскулярную и ренин-ангиотензиновую системы. В целом, эти результаты подтверждают участие ПТГрП в регуляции почечной и системной гемодинамики. Действительно, различные вазоконстрикторы, включая ангиотензин II (AngII), эндотелин-1 (ET-1) и тромбин, индуцировали экспрессию гена ПТГрП в глакомышечных структурах сосудов крыс (Hongo T. et al., 1991; Pirola C.J. et al., 1993). Ранние исследования показали, что ПТГрП является регуляторным фактором тонуса почечных сосудов действующим через сложные механизмы (Massfelder T. et al., 1996; Vasavada R.C. et al., 1998; Saussine C. et al., 1993).

В исследовании с использованием премутантных мышей штамма ПТГрП (SM-/-), который обеспечивает контролируемый во времени нокдаун ПТГрП в гладких мышцах у взрослых мышей. Воздействие тамоксифеном индуцировало эффективную рекомбинацию 
флоксированных аллелей ПТГрП и уменьшало экспрессию ПТГрП в клетках гладких мышц сосудов у мышей ПТГрП (SM-/-) (Raison D. et al., 2013). Такой специфический нокдаун ПТГрП гладких мышц был использован для анализа вклада эндогенного ПТГрП врегуляцию сердечно-сосудистых и почечных функций у взрослых мышей с нормальной экспрессией РTH1R. Результаты исследования позволили авторам (Raison D. et al., 2013) констатировать, что условная инактивация ПТГрП в клетках гладких мышц сосудов вызывает почечные реакции, существенно отличающиеся от нефротропных эффектов, зафиксированных в работах, процитированных в начальной части данного раздела обзора. Нокдаун ПТГрП не изменял кровяное давление, но был связан с почечным фенотипом, характеризующимся сужением сосудов почек и уменьшением выделения ренина, что приводило к снижению скорости клубочковой фильтрации и фракции фильтрации. На самом деле концентрация ренина в плазме уменьшалась, а почечное сосудистое сопротивление увеличивалось. Снижение скорости фильтрации свидетельствует о том, что повышение прегломерулярного сосудистого тонуса было выше, чем у постгломерулярных артериол.

Исследование роли эндогенного сосудистого ПТГрП в почечной гемодинамической реакции, вызванной экспериментальной острой перегрузкой почек изотоническим раствором (SVE) показало, что у мышей с нокдауном ПТГрП в гладких мышцах SVE-индуцированная вазодилатация почек нарушается, а также уменьшается фракция фильтрации. У контрольных мышей объемная перегрузка вызвала увеличение почечного плазменного потока без изменения скорости клубочковой фильтрации предполагая, что вазодилатация произошла как на прегломерулярных, так и на постгломерулярных артериолах без изменения гидростатического давления в гломерулярных капиллярах. Этот ответ способствует восстановлению гомеостаза жидкости и натрия. Торможение этого ответа после условного нокдауна ПТГрП гладкой мускулатуры свидетельствует о том, что местно продуцируемый ПТГрП необходим для почечной гемодинамической реакции на объемную перегрузку. SVE может усиливать синтез ПТГрП в сосуде за счет повышения артериального давления, о чем ранее сообщалось 
в отношении почечных артериол гипертензивных крыс (Massfelder T. et al., 2002) или в результате stretch - стресса, обнаруженного в культуре гладкомышечных сосудистых клеток (Schordan E. et al., 2004). Интересно, что ПТГрП способен индуцировать вазодилатацию как на афферентных, так и на эфферентных артериолах после ингибирования системы ренин-ангиотензин (Endlich K. et al., 1995). Несколько механизмов ингибируют высвобождение ренина во времяо строй перегрузки почек изотоническим раствором (повышение артериального давления, перегрузка натрием, высвобождение натрийуретического пептида в предсердии) и противодействуют стимулирующему действию ПТГрП как такового. Вызванное SVE уменьшение фракции фильтрации является частью почечной реакции, которая способствует повышению экскреции натрия и воды. Представленные результаты демонстрируют, что сосудистый ПТГрП необходим для почечной гемодинамической реакции, чтобы управлять объемной перегрузкой и восстанавливать баланс жидкости и натрия. Вазодилатация почек, индуцированная эндогенным ПТГрП, необходима для этого гомеостатического ответа. В целом, представленные результаты свидетельствуют о том, что эндогенный сосудистый ПТГрП почек с нормальной экспрессией PTH1R способствует регуляции почечной гемодинамики. В этом отношении почечное сосудистое русло отличается от других сосудистых русел.

Показано, что сигнальные пути, включающие оксид азота, а также аденилатциклазу стимулируются во время вазодилатации, вызванной ПТГрП (1-34) в изолированной перфузируемой почке (Musso M.J. et al., 1989b; Simeoni U. et al., 1994). Эти данные являются прямым доказательством того, что экзогенный ПТГрП при отсутствии его системного эффекты, увеличивает почечный кровоток, скорость клубочковой фильтрации мочи в естественных условиях. ПТГрП и ПТГ были эквипотентными в увеличении почечного кровотока, и их реноваскулярные эффекты могли быть существенно ингибированы двумя различными структурными аналогами, что указывает на механизм опосредованный общим PTH1R рецептором (Massfelder T. et al., 1996). 
Парадоксальные эффекты ПТГрП наблюдались и в крысиных ГТС-клетках, культивируемых из интраренальных небольших артерий. ПТГрП ингибирует пролиферацию через PTH1R-зависимый механизм и стимулирует пролиферацию через интракринный путь, который, по-видимому, включает в себя ядрышковую транслокацию белка (Massfelder T. et al., 2001). Важно отметить, что в этих исследованиях парадоксальные эффекты ПТГрП на клеточную пролиферацию были выявлены в почечных ГТС клетках, культивируемых из изолированных внутрипочечных артерий спонтанно гипертензивных крыс с установленной гипертензией в условиях рецептор-опосредованной стимуляции интракринного ингибирования клеточной пролиферации. Предполагается, что изменение паракринного пролиферативного эффекта обусловлено преимущественным связыванием PTH1R-рецептора с регуляторным белком Gi в клетках ГТС спонтанно гипертензивных крыс. Механизм, посредством которого стимулирующий пролиферацию клеток ГТС эффект ПТГрП парадоксальным образом трансформируется в ингибирующее действие в клетках почечной ГТС спонтанно гипертензивных крыс остается неясным, но предположительно отражает различия в деформации трофических эффектов, индуцируемых транслокацией пептида в ядрышко. Предполагается, что ПТГрП может участвовать в некоторых из этих событий, влияющих на различные пути между нормотензивными и генетически гипертензивными крысами. В совокупности эти данные показывают, что ПТГрП может играть роль регулятора отрицательной обратной связи гиперплазии стенки сосудов почки, которая способствует прогрессированию гипертензивного состояния в модели спонтанно гипертензивных крыс (Massfelder T. et al., 2001). Из этих результатов вытекает новая концепция, согласно которой одна молекула может оказывать противоположное воздействие на пролиферацию ГТС в физиологических и патофизиологических условиях. Эта концепция объясняет возможную роль ПТГрП в регуляции ремоделирования сосудистой стенки, которая может быть связана с локализацией белка или его фрагмента в ядре клетки in vivo (Clemens T.L. et al., 2001). 


\subsection{3. Паратгормон-родственный протеин и патодогия почек}

Исследованиями последних трех десятилетий продемонстрирована роль ПТГрП при почечной недостаточности. Избыточная почечная экспрессия ПТГрП зафиксирована при несколько острых, а также хронических нефропатиях (Fiaschi-Taesch N.M. et al., 2004; Izquierdo A. et al., 2006; Largo R., et al., 1999; Lorenzo O. et al., 2002; Rámila D., et al., 2008; Santos S. et al., 2001). Гиперэкспрессия ПТГрП в почках при хроническомих повреждении может быть частью механизма обратной связи, нацеленного на противодействие эффектам других вазоактивных факторов, таких как ангиотензин II, принимая во внимание влияние ПТГрП на тонус сосудов и прямое расслабляющее действие ПТГрП на мезангиальные клетки (Bosch R.J. et al., 1999).Тем не менее, другие эффекты ПТГрП имеют противоположные последствия для клубочковой гемодинамики, такие как эффекты на продукцию ренина и пролиферацию мезангиальных клеток (Soifer E.N. et al., 1993; Saussine C. et al., 1993). Таким образом, ПТГрП, по-видимому, является фактором со сложной ролью в механизмах, связанных с прогрессированием заболеваний почек.

Констатируется, что ПТГрП активируется при различных экспериментальных нефропатиях (Esbrit P. et al., 2007). Разработка модели трансгенной мыши, характеризующейся сверхэкспрессией ПТГрП в почечных проксимальных канальцах, позволила исследовать функциональные последствия хронической избыточной экспрессии ПТГрП на экспериментальных моделях повреждения почек (Bosch R.J. et al., 2011). Этот новый подход предоставил ценные данные, которые помогли раскрыть истинную роль ПТГрП в поврежденной почке. Известно, что ПТГрП активируется при нескольких экспериментальных нефропатиях, таких как острая почечная недостаточность (ARF), обструктивная нефропатия (ON), а также диабетическая нефропатия (DN).Исследования по определению патофизиологической роли ПТГрП в почечном контексте были проведены с использованием экспериментальных моделей тубулоинтерстициального или гломерулярного повреждения. В этих исследованиях было продемонстрировано прямое влияние ПТГрП, показавшее важную роль этого белка в механизмах, которые регулируют клеточный 
цикл, воспаление и фиброз, что указывает на возможность поиска новых путей терапевтического вмешательства (Ortega et al., 2006; Rámila et al., 2008; Romero et al., 2010). Считается, что ПТГрП является нефротропным фактором, который может играть потенциальную терапевтическую роль в восстановлении почечной функции после поражения почек (Soifer E.N. et al., 1993; Garcia-Ocana A. et al., 1995; 1999; Santos S. et al., 2001; Largo R. et al., 1999; Esbrit P. et al., 2001).

\subsubsection{1. Паратгормон-родственный протеин при врожденных аномалиях почек и мочевыводящих путей (CAKUT)}

Известно, что повышенная продукция ПТГрП злокачественными новообразованиями почек может индуцировать развитие гиперкальциемии Очень редко гуморальная гиперкальциемия ассоциируется с доброкачественными состояниями. Grob F. et al. (2013) сообщили о случае ребенка с III стадией хронической почечной недостаточности, вторичной по отношению к мультипластической диспластической болезни почек, у которого в течение 3 месяцев жизни наблюдалась тяжелая гиперкальциемия при сниженной продукции паратгормона и повышенным сывороточным уровнем ПТГрП. Злокачественная опухоль была исключена. После лечения бисфосфонатами уровень кальция снизился и оставался в нормальных пределах в сыворотке крови в течение 1 года после выписки. Авторы пришли к выводу, что присутствие повышенного содержания ПТГрП, может играть роль в гиперкальциемии, связанной с мультипластической диспластической болезнью почек, возможно, из-за перепроизводства этого протеина в почке.

Идиопатическая гиперкальциемия у детей с дисплазией почек, не так уж редко встречается и была отмечена у 15 из 99 наблюдавшихся младенцев большинство из которых имели нормальные сывороточные уровни 25-гидроксивитамина $\mathrm{D}$, фосфата и паратгормона (Al Kalbani N. et al., 2011).

Kodous N. et al. (2015) описали наблюдение ребенка с врожденными аномалиями почек и мочевыводящих путей (CAKUT), хронической болезнью почек 2-й стадии (ХБП) и дисплазией почек с тяжелой гиперкальциемией у которого ПТГрП был повышен, 
и никаких признаков злокачественного новообразования обнаружено не было. У ребенка при обследовании были обнаружены двусторонняя почечная дупликация и двусторонние уретероцеле, соответствующие верхним частям с пузырно-мочеточниковым рефлюксом 5 степени в обеих нижних частях. Уретероцеле лечили с помощью двусторонних разрезов. Авторы пришли к выводу, что гиперкальциемия могла быть результатом перепроизводства ПТГрП у пациента c CAKUT на фоне подавленной секреции паратгормона. Внутривенная гидратация, фуросемид и кальцитонин облегчают быструю нормализацию сывороточного кальция, и нормокальциемия может поддерживаться с помощью CalciLo (детская смесь с низким содержанием кальция и витамина D, которая содержит 1/10 концентрации кальция в грудном молоке).

\subsubsection{2. Взаимодействие между паратгормон-родственным протеином и ангиотензином II в поврежденной почке}

Известно, что система ренин-ангиотензин играет важную роль в механизмах повреждения почек (Egido J., 1996; Harris, MartinezMaldonado, 1995). Основной агонист этой системы Ang II рассматривается, как фактор, который может способствовать прогрессированию повреждения почек (Mezzano S.A. et al., 2001; Ruiz-Ortega M., Egido J., 1997). Было показано, что активация компонентов системы ренин-ангиотензин, в том числе ангиотензина II, локально в почке, происходит рано на различных экспериментальных моделях острой почечной недостаточности, например, индуцированной фолиевой кислотой нефротоксичностью или ишемией/реперфузией (Allred A.J. et al., 2000; Kontogiannis J., Burns K.D., 1998; Ortega et al., 2005; Santos et al., 2001).

Существующие данные убедительно свидетельствуют о том, что ПТГрП может участвовать в механизмах, связанных с повреждением почек, вызванным ангиотензином II. Экзогенно вводимый Ang II через его рецептор 1-го типа увеличивал экспрессию ПТГрП в клубочковых и тубулярных клетках. Напротив, продукция мРНК PTH1R увеличивалась в мезангиальных клетках и подавлялась в тубулярных клетках, но уровни белка в нем не изменялись. После 
системной инфузии Ang II нормальным крысам иммуноокрашивание ПТГрП в основном выявлялось в почечных канальцах и появлялось в клубочках и почечных сосудах. Антагонист рецептора ангиотензина 1-го типа значительно уменьшал индуцированную Ang II сверхэкспрессиюПТГрП и PTHR1 в почечной ткани. Результаты показывают, что Ang II регулирует почечную систему ПТГрП/РТН1R через рецепторы ангиотензина 1-го типа.

Установлено, что активация ПТГрП происходит в связи с механизмами Ang II-индуцированного повреждения почек. Это даказано значительной корреляцией между избыточной экспрессией ПТГрП и повреждением канальцев и фиброзом в почках крыс после системной инфузии Ang II, которая индуцирует почечную систему ПТГрП/PTH1R (Lorenzo et al., 2002). Более того, антагонисты Ang II оказывают благоприятное влияние на функцию почек при различных экспериментальных моделях их повреждения (Abdulkader R.C. et al.; Long G.W. et al., 1993; Ortega A. et al.). Антагонисты рецептора ангиотензина II обеспечивают защиту почек, по-видимому, путем ингибирования NF-кB-зависимых провоспалительных путей (Lee F.T. et al., 2004; Suzuki Y. et al., 2003). При остром токсическом повреждении почек улучшение почечной функции антагонистами Ang II было связано с ингибированием гиперэкспрессии ПТГрП (Ortega A. et al., 2005). В совокупности агрегированные данные свидетельствуют, что Ang II является вероятным фактором, ответственным за гиперэкспрессию ПТГрП, а ПТГрП может способствовать вредному воздействию ангиотензина II в поврежденной почке. Эти результаты могут дать новое понимание хорошо известных защитных эффектов антагонистов Ang II при заболеваниях почек, возможно, проложив путь к новым терапевтическим подходам.

\subsubsection{3. Паратгормон-родственный протеин и тубулоинтерстициальная нефропатия}

Хроническое введение крысам циклоспорина, который вызывает интерстициальный фиброз и трубчатую атрофию активирует экспрессию в почках мРНК ПТГрП и приводит к резкому увеличению ПТГрПв почечной коре (García-Ocaña A. et al., 1998). Избыточная 
экспрессия ПТГрП в почечной коре при хроническом повреждени почек может быть частью механизма обратной связи, ограничивающего почечные эффекты ангиотензина II и, возможно, других вазоактивных факторов. Однако другие эффекты ПТГрП оказывают противоположное влияние на гломерулярную гемодинамику, на продукцию ренина и пролиферацию мезангиальных клеток (Soifer E.N. et al., 1993; Saussine C. et al., 1993). Таким образом, существующие данные указывают на ПТГрП, как фактор, участвующий в сложных механизмах, связанных с прогрессированием заболеваний почек.

В исследовании Largo R. et al., (1999) почечная экспрессия ПТГрП и РТH1R была оценена в экспериментах с моделированием y крыс интенсивной протеинурии и тубулоинтерстициальной нефропатии, вызванной перегрузкой белком, которая вызывалась ежедневными внутрибрюшинными инъекциями 1 г бычьего сывороточного альбумина (BSA) (Eddy A.A., 1989). Ранее сообщалось, что наличие протеинурии как при заболеваниях почек человека, так и при экспериментальных поражениях почек коррелирует со скоростью прогрессирования почечной недостаточности до терминальной стадии (Remuzzi G. et al., 1997). Кроме того, снижение скорости клубочковой фильтрации показывает более высокую корреляцию с тубулоинтерстициальными повреждениями, чем с гломерулярными повреждениями (Remuzzi G. et al., 1997). Было обнаружено, что мРНК ПТГрП резко увеличивается в почечной коре крыс с тубулоинтерстициальной нефропатией, вызванной перегрузкой BSA. Установлено, что мРНК ПТГрП последовательно возрастает в корковой зоне почек во время развития протеинурии. Напротив, мРНК PTH1R уменьшалась у этих животных, возможно, вследствие увеличения концентрации внутриклеточного кальция, наблюдаемого при хронической почечной недостаточности (Marcinkowski W. et al., 1997). ПТГрП-иммуноокрашивание у крыс получавших BSA увеличивалось как в проксимальных, так и в дистальных канальцах и в клубочках, где присутствие ПТГрП обнаружено в мезангиальных и эндотелиальных клетках. Значимость последнего факта неизвестна, но может быть связана с увеличенным мезангиальным ростом, наблюдаемым у таких животных (Largo R. et al., 1999). 
В ткани почек микроскопически выявлено поражение канальцев, инфильтрация мононуклеарных клеток. Экспрессия мРНК ПТГрП в почечной коре была значительно увеличена у животных, перегруженных BSA, по сравнению с контрольными крысами. Иммуногистохимический анализ с использованием двух различных антиПТГрП-антител показал резкое увеличение окрашивания ПТГрП в поврежденных проксимальных и дистальных канальцах у крыс с моделированием тубулоинтерстициального повреждения почек. У этих животных также наблюдалось интенсивное иммуноокрашивание ПТГрП в гломерулярных мезангиальных и эндотелиальных клетках. Обнаружено, что взаимное снижение мРНК PTH1R и иммуноокрашивание без существенных изменений в клеточной локализации рецепторов PTH1R происходит в почечной коре BSA- перегруженных крыс. Рецептор PTH1R был выявлен главным образом на просветных и базолатеральных мембранах канальцев и в гломерулярных эпителиальных и мезангиальных клетках у крыс, перегруженных BSA. Ранее было показано наличие рецепторов PTH1R в клубочках кролика, а мРНК РТН1Rбыла локализована в гломерулярных подоцитах путем гибридизации in situ (Lee K. et al., 1996; Massfelder T. et al., 1993). Следовательно, повышенная позитивность ПТГрП в клубочках крыс, перегруженных BSA, могла быть обусловлена увеличением связывания ПТГрП с его рецептором.

Одновременно с повышающей регуляцией ПТГрП, наблюдалось увеличение экспрессии ангиотензинпревращающего фермента и гена препроэндотелина-1 в почечной коре у животных с моделированием тубулоинтерстициального повреждения почек. Эти результаты показали, что ПТГрП может активироваться в клетках проксимальных канальцев в ответ на интенсивную протеинурию и позволили предположить, что вазоактивные гормоны ангиотензин II и эндотелин-1 могут участвовать в выработке ПТГрП в почечной коре крыс с перегрузкой BSA. Существующие данные свидетельствуют, что факторы, отличные от ПТГрП или Ang II, вероятно, индуцируют снижение уровня РТH1R, связанное с поражением почек (Fiaschi-Taesch N.M. et al., 2004.; Lorenzo O. et al., 2002). Тем не менее, снижение мРНК РТН1R, не было столь резким, как 
наблюдаемое повышение мРНК ПТГрП, которое может определяться относительным избытком рецептора PTH1R в почечной ткани (Lee K. et al., 1996). В этой связи другими исследованиями показано, что хроническая почечная недостаточность связана с повышением уровня цитозольного кальция, что, в свою очередь, вызывает подавление многих белков, в том числе рецептора PTH1R в почках (Ureña P. et al., 1994; Marcinkowski W. et al., 1997).

Факторы, ответственные за наблюдаемые изменения в ПТГрП и рецепторе $\mathrm{PTH} 1 \mathrm{R}$, связанном с повреждением почек после перегрузки BSA in vivo, неизвестны. Прохождение белка через базальную мембрану клубочков вызывает повышенную реабсорбцию белка культивируемыми проксимальными канальцевыми клетками (Benigni A. and Remuzzi G., 1996), индуцируя выработку воспалительных цитокинов, таких как трансформирующий фактор роста- $\beta$; (TGF- $\beta$;) и вазоактивных агентов, например, эндотелин-1 и Ang II (Eddy A.A. and Giachelli C.M., 1995; Zoja C. et al., 1995; Largo R. et al., 1997). In vivo TGF- $\beta$ коррелирует с интерстициальным фиброзом, наблюдаемым у животных с моделированием тубулоинтерстициального повреждения почек.

Предполагается, что некоторые из этих факторов могут быть вовлечены в изменения рецепторов РТH1R, наблюдаемые после перегрузки BSA. Механизмы, с помощью которых Ang II и эндотелин-1 могут регулировать экспрессию гена ПТГрП, неизвестны. Показано увеличении активности ядерного фактора кB (NF-кB) в почечной коре BSA-перегруженных крыс, в основном расположенных в проксимальных канальцах и интерстициальных мононуклеарных клетках. Кроме того, в культивируемых тубулоэпителиальных клетках индуцированная BSA активация NF-кB была вызвана, по крайней мере частично, Ang II и эндотелином-1 (Gómez-Garre D. et al., 1998). Также известно, что Ang II и эндотелин-1 являются мощными активаторами мобилизации [Ca2+] в различных почечных клетках, включая мезангиальные (Ichikawa I., Harris R.C., 1991; Simonson M.S., 1993), предполагая возможный механизм, с помощью которого может происходить подавление рецептора PTH1R у животных с моделированием тубулоинтерстициального повреждения почек. 
Патфизиологическая роль ПТГрП при поражении почек неясна. Поскольку культивируемые тубулярные и мезангиальные клетки пролиферируют после стимуляции либо ПТГрП, либо ПТГ (Soifer E.N. et al., 1993; García-Ocaña A. et al., 1995), предполагается, что BSA-индуцированная избыточная экспрессия ПТГрП в почках может увеличить рост этих клеток с помощью аутокринных или паракринных механизмов. В этом смысле у крыс с перегрузкой BSA отмечена определенная связь между экспрессией гена ПТГрП и поражениями почек. Таким образом, продемонстрировано, что в модели тубулоинтерстициального повреждения, вызванного перегрузкой BSA, ПТГрП последовательно повышался в почечной коре, главным образом в проксимальных и дистальных канальцах, и появлялся в гломерулярных мезангиальных и эндотелиальных клетках, тогда как почечная экспрессия его рецептора была подавлена. Полученные данные предполагают, что вазоактивные гормоны Ang II и эндотелин-1 могут участвовать в повышающей регуляции ПТГрП у животных с моделированием тубулоинтерстициального повреждения почек.

\subsubsection{4. Паратгормон-родственный протеин при токсическом поражении почек}

Существуют данные указывающие на участие ПТГрП в механизмах, связанныхс прогрессированием повреждения почек. Как дисфункция, так и потеря тубулярных эпителиальных клеток играют центральную роль в механизмах повреждения почек после токсического или ишемического воздействия (Lieberthal W., Levine J.L., 1996; Zuk A. et al., 1998). В тубулярном эпителии ПТГрП имеет митогенные особенности, и его избыточная экспрессия происходит быстро в экспериментальных моделях нескольких нефропатий (Esbrit P. et al., 2001; Garcia-Ocana A. et al., 1995; Garcia-Ocana A. et al., 1999). Однако избыточная экспрессия ПТГрП в проксимальных канальцах почек оказалась неэффективной для защиты от нефротоксического повреждения почек у мышей (Fiaschi-Taesch N.M. et al., 2004). Установлено, что ПТГрП может способствовать повреждению канальцев, ухудшению почечной функции и фиброзу после нефротоксического повреждения у грызунов. (Lorenzo O. et al., 2002; Ortega A. et al., 2005; 
Ortega A. et al., 2006). Показано, что хроническое введение циклоспорина крысам вызывает канальцевую атрофию и интерстициальный фиброз, что связано с повышенной экспрессией ПТГрП как на уровне мРНК, так и на уровне белка в коре почки (Garcia-Ocaña et al., 1998).

Ortega A., et al. (2006) исследовали роль ПТГрП в нефротоксичности фолиевой кислоты (ФК), при которой происходит острое повреждение почек, связанное с ранней активацией ПТГрП с последующей частичной регенерацией и пятнистым тубулоинтерстициальным фиброзом в течение нескольких недель (Santos S. et al., 2001; Ortega A. et al., 2005; Yuan H.T. et al., 2003). В этих экспериментах авторы использовали трансгенных мышей (ПТГрП-ТG мыши), сверхэкспрессирующих ПТГрП в почечных проксимальных канальцах, а также тубулоэпителиальную клеточную культуру NRK-52E крысы (ATCCCRL 1571) и культуру фибробластических почечных клеток NRK-49F.

Результаты исследований in vitro, показали, что ПТГрП (1-36) может индуцировать продукцию $\alpha$-SMA (alpha-smooth muscle actin), играющего важную роль в фиброгенезе, в почечной фибробластной клеточной линии и стимулировать экспрессию проколлагена и фибронектина 1-го типа в этой клеточной линии и в тубулоэпителиальных клетках. В совокупности эти результаты позволяют предположить, что ПТГрП, по-видимому, действует как фиброгенный медиатор при нефротоксичности ФК. Обнаружено, что избыточная экспрессия ПТГрП и фиброз были связаны с дисбалансом апоптоза и пролиферации клеток в пользу пролиферации, что привело к общему увеличению интерстициальных фибробластов в почке мыши после повреждения ФК. Результаты исследований позволили предположить, что в этой ситуации ПТГрП может стимулировать приток макрофагов, непосредственно увеличивая синтез моноцитарного хемотаксического протеина-1 в тубулоэпителиальных клетках. В совокупности эти результаты показывают, что избыточная экспрессия ПТГрП в проксимальных канальцах связана с воспалением и тубулоинтерстициальным фиброзом после нефротоксичности, вызванной ФК.

Эти результаты также демонстрируют, что ПТГрП может действовать непосредственно как фактор выживания для тубулоинтерстициальных клеток. Обнаружено, что конститутивная активация 
антиапоптотического белка Bcl-xL происходит в почках трансгенных мышей ПТГрП-ТG, сверхэкспрессирующих ПТГрП в почечных проксимальных канальцах, и эта активация, а также пролиферативный и антиапоптотический ответ почечных интерстициальных клеток на ФК были предотвращены индуцированной доксициклином реверсией избыточной экспрессии ПТГрП у этих мышей. Эти эффекты были отменены антагонистом PTH1R, предполагая, что они могут опосредоваться через этот рецептор в этих клетках. Кроме того, ингибитор панкаспазы значительно уменьшал вызванное ФК снижение выживаемости клеток в присутствии или в отсутствие ПТГрП (1-36) в клетках почек, что еще больше подтверждает антиапоптотический эффект этого пептида. В целом аналируемое исследование демонстрирует, что общие эффекты ПТГрП, по-видимому, являются провоспалительными и профиброгенными в почке, поврежденной ФК. Результаты подтверждают гипотезу о том, что ПТГрП может способствовать прогрессированию повреждения почек при нефротоксическом повреждении почек с помощью сложных механизмов: увеличения выживаемости тубулоинтерстициальных клеток и индукции инфильтрации макрофагов и активации фибробластов (Ortega A. et al., 2006).

\subsubsection{5. Ишемическое поражение почек и паратгормон-родственный белок}

ПТГрП увеличивается in vivo в ответ на либо ишемическое повреждение почек, либо на хроническую индуцированную циклоспорином нефротоксичность, а также на модели in vitro, которая имитирует ишемическое повреждение канальцев (Soifer E.N. et al., 1993; Galbraith S.C. et al., 1996; García-Ocaña A. et al., 1998). Повышение уровня ПТГрП после острой почечной ишемии было обнаружено в клубочках, но только в эпителиальных клетках. Наблюдаемое при этом увеличение мРНК ПТГрП сопровождалось снижением экспрессии мРНК рецептора PTH1R (Soifer E.N. et al., 1993).

Было показано, что экспрессия эндогенного ПТГрП в проксимальных канальцах крыс повышается после ишемического повреждения in vivo (Soifer N.E. et al., 1993), что позволило предположить, что ПТГрП может участвовать в регенерации канальцев во время 
восстановления после ишемии (Garcia-Ocana A. et al., 1999). Детальный анализ клеточного воздействия ишемии на проксимальные канальцы был выполнен с использованием модели истощения энергии in vitro в культивируемых клетках проксимальных канальцев (РТС) иммортализованной человеческой линии НK-2, которая сохраняет фенотипические и функциональные характеристики хорошо дифференцированной PTC (Ryan M.J. et al., 1994). Эти клетки экспрессируют рецепторы ПТГрП и рецепторы PTH1R и, таким образом, предоставляют хорошую модель для изучения влияния истощения энергии на экспрессию ПТГрП и роль ПТГрП после травмы. Использование обратимой модели истощения АТФ в клетках НК-2, позволило воспроизвести клеточные эффекты ишемического инсульта. Следствием такого повреждения является индукция ранней экспрессии генов ПТГрП и HSP-70 с временным паттерном, который имитирует то, что наблюдается после ишемического повреждения in vivo (Van Why S.K. et al., 1992).

Было показано, что ПТГрП действует как ген раннего ответа в некоторых тканях и типах клеток (Allinson E.T., Drucker D.J., 1992; Holt E.H. et al., 1994), и его ранняя экспрессия после ишемического повреждения и истощения АТФ позволяет предположить, что он может участвовать в регенеративном процессе. Хотя уровни большинства форм мРНК снижаются в почках крыс после ишемии, быстрое увеличение мРНК генов раннего ответа, таких как c-Fos, Egr-1 и ПТГрП, происходит после острого повреждения почек, что указывает на их роль в пролиферативном ответе почечных канальцев (Toback F.G., 1992; Safirstein R. et al., 1990).

Поскольку ПТГрП обладает митогенными свойствами в ряде различных типов почечных клеток (García-Ocaña A. et al., 1995; Burton P.B.J. et al., 1990) и поскольку экспрессия мРНК ПТГрП в РТС активируется рано после повреждения была исследована роль ПТГрП в пролиферативном ответе после истощения АТФ в клетках НК-2. С этой целью использовали антитела к аминоконцевой области ПТГрП, которая, как известно, стимулирует синтез ДНК через протеинкиназа-С-зависимый механизм (García-Ocaña A. et al., 1995). В присутствии анти-ПТГрП-нейтрализующих антител после 
истощения АТФ наблюдалось значительное связанное со временем и дозой снижение количества клеток и синтеза ДНК. Эффекты антител к ПТГрП на рост клеток, по-видимому, опосредованы специфическими действиями эндогенно продуцируемого ПТГрП. Эти данные согласуются с аутокринным эффектом эндогенно секретируемого ПТГрП на ростклеток НК-2 в течение периода восстановления после истощения АТФ и предполагают, что ПТГрП может играть роль в почечном регенеративном процессе после повреждения.

Однозначные и последовательные эффекты антител против ПТГрП на синтез ДНК и рост клеток после повреждения позволили авторам исследования предположить, что ПТГрП служит важным фактором роста, который наряду с другими цитокинами участвует в постинфарктном пролиферативном ответе (Garcia-Ocana A. et al., 1999). Следовательно, ПТГрП, продуцируемый в проксимальных канальцах, может участвовать вместе с установленными цитокинами и факторами роста, такими как эпидермальный фактор роста (Humes H.D. et al., 1989), IGF-1 (Miller S.B. et al., 1992) и фактор роста гепатоцитов (Miller S.B. et al., 1994), продуцируемых в соседних клеточных типах, в регуляции усиления пролиферативного ответа на ишемическое повреждение и ускорение восстановления нормальной функции почек.

Однако по данным Fiaschi-Taesch N.M. et al. (2004), полученным в экспериментах на трансгенных мышах с контролируемой гиперэкспрессией ПТГрП, избыточная продукция этого протеина в проксимальных канальцах оказалась неэффективной для защиты почек от ишемического повреждения. Несмотря на многообещающие наблюдения in vitro, сверхэкспрессия ПТГрП в проксимальных канальцах in vivo не приводила к какому-либо значительному функциональному или морфологическому улучшению в остро поврежденной почке и не предотвращала острого ухудшения почечной функции после ишемии/реперфузии. Для подтверждения очевидного отсутствия протективного эффекта сверхэкспрессии ПТГрП при остром ишемическом повреждении почек авторы проанализировали ответ мышей, сверхэкспрессирующих ПТГрП, в экспериментах с использованием другой модели повреждения почек путем внутрибрюшинного введения высокой дозы фолиевой кислоты. Отсутствие протективного 
эффекта ПТГрП у мышей после почечной ишемической травмы может быть теоретически связано с подавлением экспрессии ПТГрП или PTH1R в почке. Анализ экспрессии ПТГрП в экстрактах почек трансгенных мышей с гиперэкспрессией ПТГрП с помощью вестернблоттинга показал, что уровень ПТГрП через 24 или 48 ч после ишемии/реперфузии оставался повышенным по сравнению с уровнем у контрольных мышей в исходных условиях. Ранее сообщалось, что подавление рецептора PTH1R после острой почечной недостаточности (Santos S. et al., 2001; Soifer E.N. et al., 1993), может объяснять отсутствие эффекта сверхэкспрессированного ПТГрП на восстановление почек после их острого повреждения. Вестерн-блот-анализ экстрактов почек у мышей сверхэкспрессирующих ПТГрП в разное время после индукции острого повреждения почек в обеих экспериментальных моделях показал,что уровни белка PTH1R резко снижались в почках этих мышей через 48 часов после ишемии/реперфузии или 72 часа после инъекции фолиевой кислоты. В совокупности эти результаты указывают на то, что острое повреждение почек, но не конститутивная избыточная экспрессия ПТГрП в проксимальных канальцах, подавляет РTH1R в почке.

\subsubsection{6. Паратгормон-родственный протеин при воспалении и фиброзе почек}

Воспаление включает в себя сложные молекулярные и клеточные механизмы, которые активируются против повреждающих факторов и обычно служат положительной биологической цели, но оно может иметь пагубные последствия при хронических патологических состояниях, таких как прогрессирующие заболевания почек (Chevalier R.L., 2006; Rees A.J., 2006; Remuzzi G., Bertani T., 1998). Воспаление играет ключевую роль в прогрессирующем рубцевании и фиброгенезе при различных заболеваниях почек (Remuzzi G., Bertani T.N., 1998; Chevalier R.L., 2006; Rees A.J., 2006; Strutz F., Neilson E.G., 2003). Тубулоинтерстициальное воспаление является ключевым событием при различных нефропатиях. Известно, что тубулоинтерстициальное воспаление способствует интерстициальному фиброзу и прогрессированию повреждения почек 
(Strutz F., Neilson E.G., 1994; Strutz F., Neilson E.G., 2003). После повреждения почек тубулоэпителиальные клетки начинают сверхэкспрессировать провоспалительные цитокины и хемокины, которые способствуют миграции моноцитов/макрофагов и Т-лимфоцитов в почечный интерстиций (Muller G.A. et al., 1992; Rees A.J., 2006). Как инфильтрирующие лейкоциты, так и поврежденные тубулоэпителиальные клетки активируют и индуцируют пролиферацию резидентных фибробластов в тубулоинтерстициальном компартменте. Тяжелое и длительное повреждение определяет устойчивую активацию провоспалительных путей, связанных с избыточной экспрессией профиброгенных цитокинов тубулоинтерстициальными клетками, что приводит к фиброгенезу и потере почечной функции (Strutz F., Neilson E.G., 2003).

Установлено что ПТГрП может действовать как провоспалительный фактор при различных патофизиологических состояниях (Martin-Ventura J.L. et al., 2003). Показано, что ПТГрП может выступать в качестве важного индуктора провоспалительных цитокинов, а именно фактора некроза опухоли и интерлейкина-6, при полиорганном воспалении (Funk J.L., 2001). Продемонстрировано, что ПТГрП активирует ядерный фактор NF-kB и экспрессию NF-kB-зависимых цитокинов и хемокинов и в том числе IL-6 и хемоаттрактантного белка-1 моноцитов (MCP-1) в различных типах клеток (Guillén C. et al., 2002; Martín-Ventura J.L. et al., 2003). Показано, что NF-кB-связанные факторы, по-видимому, играют важную роль в воспалении, связанном с повреждением почек (Gómez-Garré D. et al., 2001; Lee F.T. et al., 2004; Guijarro C., Egido J., 2001; Morrissey J.J., Klahr S., 1997).

Повреждение мезангиальных клеток (MC) является характерной чертой гломерулонефрита. Активированные МС секретируют медиаторы воспаления, которые вызывают апоптоз клеток. ПТГрП является локально активным полигормоном, который повышает выживаемость клеток и активируется провоспалительными факторами во многих типах клеток. Резудьтаты исследования регуляции экспрессии ПТГрП провоспалительными цитокинами и оценка роли, самогоПТГрП в качестве провоспалительного фактора или фактора выживания мышиных мезангиальных клеток в культуре показали, 
что IL-1 $\beta$ и TNF- $\alpha$ быстро и временно повышали экспрессию ПТГрП в MC (Hochane M. et al., 2018). Эффекты IL-1ß были как транскрипционными, так и посттранскрипционными со стабилизацией мРНК ПТГрП человеческим антигеном R. Массивы профиля протеома показали, что сам ПТГрП усиливал цитокины в клеточных лизатах, главным образом, IL-17, IL-16, IL-1 $\alpha$ и IL-6. ПТГрП также стимулировал устойчивую экспрессию хемокинов, в основном регулируемых активацией экспрессируемых и секретируемых нормальных Т-клеток (RANTES)/CC-хемокина 5 (CCL5) и макрофагального воспалительного белка-2 (MIP-2)/СХС-мотива хемокинов 2 (CXCL2),/тимусом и активацией регулируемый хемокин (TARC-thymus and activation regulated chemokine)/CCL17, и индуцируемый интерфероном $\alpha$-хемоаттрактант Т-клеток (I-TAC)/CXCL11. Более того, ПТГрП заметно усиливал экспрессию циклооксигеназы-2 (ЦОГ-2) и вызывал его автоиндукцию посредством активации пути NF-кB. ПТГрП индуцировал выживание MC через продукты COX-2, а избыточная экспрессия ПТГрП в МС уменьшала апоптотические эффекты IL-1 $\beta$ и TNF- $\alpha$. В целом, эти результаты подтверждают, что ПТГрП действует как стимулятор воспалительных процессов в клубочках и может быть компонентом отрицательной обратной связи, сохраняющей выживаемость MC (Hochane M., 2018). Таким образом ПТГрП может способствовать воспалению, пролиферации и выживанию MC (Hochane M. et al., 2013).

В той же лаборатории исследовали экспрессию и роль ПТГрП в воспалении и заживлении клубочков в экспериментальной модели гломерулонефрита, вызванной внутривенной инъекцией мышам яда змеи Хабу (Нochane M. et al., 2018). Временной анализ показал выраженное повреждение почек в первые дни после введения яда и начало выздоровления в течение 7 дней. Гломерулярная экспрессия ПТГрП (транскрипта и белка) наблюдалась на ранней стадии после введения яда (с 1-го по 3-й день) наряду с воспалительной реакцией. Инактивация секретированного ПТГрП с помощью ПТГрП-нейтрализующего антитела снижала экспрессию маркеров локального воспаления (хемотаксического белка макрофага-1; циклооксигеназы 2; IL-6 и инфильтрации макрофагов) и отменила 
экспрессию самого ПТГрП. Кроме того, пролиферация клубочковых клеток была заторможена, как и процесс заживления. Эти результаты показали, что ПТГрП обладает антиномическим действием при гломерулонефрите, участвуя как в провоспалительных состояниях, так и в процессе заживления. Эти данные раскрывают существенную роль ПТГрП в раннем восстановлении клубочков в экспериментальной модели гломерулонефрита.

В экспериментах, проведенных (Rámila D. et al., 2008) исследовали функциональные последствия хронической активации ПТГрП в почках мыши после односторонней обструкции мочеточника, характеризующейся ранним воспалительным ответом почек (Chevalier R.L., 2006; Esteban V., Lorenzo O. et al., 2004). Результаты экспериментов с моделированием почечного воспаления на мышах с односторонней обструкцией мочеточника-показали критическую роль ПТГрП в этом состоянии (Rámila D. et al., 2008). Было обнаружено, что ПТГрП активируется даже у мышей с повышенной экспрессией ПТГрП. В отличие от предыдущих наблюдений при ишемическом или нефротоксическом повреждении почек (Rámila D. et al., 2008), PTH1R не подавлялся после обструкции мочеточника у мышей. Кроме того установлено, что после обструкции мочеточника РТНrР активирует некоторые провоспалительные факторы в тубулоэпителиальных клетках и способствует миграции моноцитов/ макрофагов. Увеличение нескольких провоспалительных факторов, а именно: белка-хемоаттрактанта моноцитов 1 (MCP-1), рецептора MCP-1 CCR2 (рецептор хемокинов (мотив C-C2), хемокина, выделяемого Т-клетками при активации хемоаттрактанта для моноцитов (RANTES), IL-6 и молекулы клеточной адгезии, присутствующей на мембранах лейкоцитов (ICAM-1) было более значительным, связанным с более выраженным повреждением канальцев, у мышей с повышенной экспрессией ПТГрП, чем у контрольных животных. Индукция экспрессии MCP-1, RANTES, IL-6 и CCR2 с помощью ПТГрП зависела, по-видимому, от активации как сигнального пути ERK (extracellular signal-regulated kinase), так и NF-кB в тубулоэпителиальных клетках. Это убедительно свидетельствует о том, что эти внутриклеточные пути участвуют в механизмах, посредством 
которых ПТГрП может способствовать воспалению почек. Более того, ERK-опосредованная активация NF-kB, по-видимому, является важным механизмом, посредством которого ПТГрП вызывает воспаление почек. Подавление эффектов повышенной продукции ПТГрП на активацию провоспалительных факторов с помощью антагониста ангиотензин 1 рецептора лозартана, который как ранее было показано, устраняет активацию ПТГрП, вызванную нефротоксическим острым повреждением почек у крыс (Ortega A. et al., 2005) было столь же эффективным, как и влияние ПТГрП (7-34), являющегося антагонистом PTH1R, в ингибировании воспаления в почке мышей с обструкцией мочеточника. Эти данные позволили авторам анализируемого исследования предположить, что ПТГрП может рассматриваться как новый маркер воспаления и потенциальная терапевтическая мишень в поврежденной почке (Rámila D. et al., 2008). Наконец, поскольку устойчивое почечное воспаление тесно связано с фиброгенезом, эти данные указывают на то, что ПТГрП является вероятным провоспалительным и профиброгенным фактором в поврежденной почке.

Прогрессирование хронического заболевания почек характеризуется непрерывным накоплением и отложением внеклеточного матрикса, что приводит к распространенному фиброзу тканей. Считается, что почечный интерстициальный фиброз является общей характеристикой хронических заболеваний почек, приводящих к терминальной стадии почечной недостаточности (Liu Y., 2004). Интерстициальные фибробласты являются основным типом клеток, ответственных за фиброгенез, процесс, в результате которого эти клетки пролиферируют и становятся активированными миофибробластами (Ardura J.A. et al., 2008). Известно, что фиброз почки индуцируется как тубулоэпителиальными, так и инфильтрирующими клетками, а также секрецией матриксных соединений, как активированными фибробластами, так и тубулярными клетками. Повышенный синтез и отложение матрикса, а также потеря целостности тубулярной структуры являются первостепенными событиями на более поздних стадиях фиброгенеза (Fan J.M. et al., 1999).

Тубулоинтерстициальный фиброз является первостепенным событием в прогрессировании хронической почечной патологии. 
Фиброгенный процесс характеризуется атрофией канальцев и накоплением белков внеклеточного матрикса, включая фибронектин, коллагены типов I, III, IV и V, а также ламинин (Chevalier R.L., 2006; Nangaku M., 2004). Экспериментальные данные свидетельствуют о том, что приток макрофагов в почечный интерстиций является ключевым шагом в развитии хронического воспаления и последующего интерстициального фиброза в поврежденной почке (Vielhauer V. et al., 2001). Фиброгенез также сопровождается увеличением пролиферации почечных интерстициальных клеток и их трансформацией в миофибробласты, основные эффекторные клетки в этой ситуации (Lewis M.P., Norman J.T., 1997; Sato M. et al., 2003). В поврежденной почке миофибробласты могут образовываться из резидентных фибробластов и из циркулирующих клеток, происходящих из костного мозга, а также посредством эпителиально-мезенхимального перехода (ЕМТ), процесса, в результате которого тубулоэпителиальные клетки становятся продуцирующими матрицу миофибробластами (Kalluri R., Neilson E.G., 2003; 27Liu Y., 2004).

Посредством трансдифференцировки $\alpha$-SMA-позитивных миофибробласто в эпителиальные клетки почечных канальцев продуцируют ряд воспалительных и фиброгенных цитокинов, таких как трансформирующий фактор роста бетта 1 (TGF- $\beta 1$ ) и фактор роста соединительной ткани, которые участвуют в дальнейшем развитии почечного интерстициального фиброза (Abbate M. et al., 2002). TGF- $\beta 1$ является профиброзным регулятором, который может стимулировать эпителиальные клетки канальцев к прохождению эпителиальной мезенхимальной трансдифференцировки, тогда как фактор роста соединительной ткани был признан одним из важных факторов, которые опосредуют фиброзную активность TGF- $\beta 1$ (Border W.A., Noble N.A., 1997) и как общий фактор, участвующий в развитии почечного интерстициального фиброза (Ito Y. et al., 1998). Исследования показали, что канальцевые эпителиальные клетки подвергаются критической трансформации по механизму эпителиально-мезенхимального перехода (Strutz F. et al., 1995). Показано, что фибробласты возникают в большом количестве локально посредством EMT (Iwano M. et al., 2002) и такие трансдифференцирующие 
эпителиальные клетки в почечных канальцах могут играть фундаментальную роль, приводя к возможному повреждению почек. Почечный интерстициальный фиброз и эпителиальная трансдифференцировка признаны в качестве ключевых этапов, приводящих к терминальной стадии почечной недостаточности.

ПТГрП проявляет рост-модулирующие и провоспалительные свойства в различных клеточных системах, включая тубулоэпителиальные клетки (Funk J.L., 2001; Ramila D. et al., 2008). ПТГрП сверхэкспрессируется при различных тубулоинтерстициальных нефропатиях, и его избыточная экспрессия коррелирует с развитием протеинурии как у мышей с диабетом, так и у крыс с тубулоинтерстициальным повреждением после перегрузки белком (Izquierdo A. et al., 2006; Largo R. et al., 1999). Исследование на мышах с нефротоксичностью, вызванной фолиевой кислотой, указывает на важную роль ПТГрП в развитии фиброгенеза почек (Ortega A. et al., 2006). Существуют данные указывающие на участие ПТГрП в механизмах, связанныхс прогрессированием повреждения почек. У крыс с хроническим интерстициальным фиброзом, индуцированным циклоспорином, выявлено повышение экспрессии мРНК ПТГрП почки и резкое увеличение иммуноокрашивания ПТГрП в почечной коре (García-Ocaña A. et al., 1998). Показано, что большее количество инфильтрирующих макрофагов было связано с повышенной пролиферацией фибробластов в интерстиции почек, поврежденных фолиевой кислотой, у мышей со сверхэкспрессией ПТГрП (Ortega A. et al., 2006). У этих мышей усиленное иммуноокрашивание на $\alpha$-SMA, маркер активированных фибробластов или миофибробластов (Strutz F. et al., 2002), также наблюдалось в почечном интерстиции после токсического поражения почек фолиевой кислотой. Эти данные, полученные в исследовании in vivo были дополнительно подтверждены результатами экспериментов in vitro, демонстрирующими, что ПТГрП (1-36) может индуцировать $\alpha-\mathrm{SMA}$ и стимулировать экспрессию проколлагена и фибронектина 1-го типа в почечной фибробластной клеточной линии и в тубулоэпителиальных клетках. В совокупности эти факты свидетельствуют, что ПТГрП, по-видимому, действует как фиброгенный медиатор при токсическом повреждении почек (Ortega A. et al., 2006). 
Кроме того, более интенсивное иммуноокрашивание коллагенов типов I и IV выявлено в почечном интерстиции почек у мышей с обструкцией мочеточника, сверхэкспрессирующих ПТГрП, чем у их нормальных однопометников (Ardura J.A. et al., 2008). Было обнаружено, что ПТГрП (1-36) стимулирует экспрессию обоих типов коллагенов, проколлагена 1-го типа и фибронектина в тубулоэпителиальных клетках и фибробластах почек in vitro. По крайней мере, часть этих эффектов была отменена антагонистом PTH1R (Ortega A. et al., 2006). Тубулоэпителиальные клетки также могут вносить вклад в развитие почечного фиброза путем непосредственной генерации миофибробластов посредством эпителиально-мезенхимального перехода (Ardura J.A. et al., 2008; Liu Y., 2004). Несколько исследований подтверждают важную роль различных профиброгенных факторов в процессе EMT в почках. TGF- $\beta$ является наиболее известным фактором, изученным в этом отношении, и, по-видимому, включает активацию MAPKs и белков Smad. Кроме того, активация тирозинкиназы рецептора эпителиального фактора роста (EGFR) может запускать EMT в почечных тубулоэпителиальных клетках (Gore-Hyer E. et al., 2002; Grände M. et al., 2002; Liu Y., 2004; Zhuang S. et al., 2004; Zhuang S. et al., 2005). Сообщалось, что ПТГрП стимулирует ЕМТ посредством взаимодействия с фактором роста эндотелия сосудов (VEGF) (Ardura J.A. et al., 2008). Предполагается, что TGF- $\beta$ может действовать как модулятор действия ПТГрП через PTH1R в почечных клетках. TGF- $\beta$ способен опосредовать ПТГрП-индуцированную гипертрофию в висцеральных эпителиальных клетках почечных клубочков - подоцитах, где ПТГрП может индуцировать активацию TGF- $\beta$ (Romero M. et al., 2010). Кроме того, стимуляция PTH1R может привести к трансактивации EGFR, что свидетельствует о важной роли ПТГрП в ЕМТ почек. Показано, что ПТГрП способен вызывать различные фенотипические изменения, связанные с ЕМТ в тубулоэпителиальных клетках (Ardura J.A. et al., 2010). Было обнаружено, что блокада TGF- $\beta$ уменьшает фиброз почек как на экспериментальных моделях повреждения почек, так и на культивируемых клетках почек. Это позволило предположить, что TGF- $\beta$ действует как нижестоящий медиатор ПТГрП. Такое же взаимодействие между этими 
двумя факторами наблюдалось при гипертрофии подоцитов, вызванной ПТГрП. Обнаружено, что два важных медиатора ЕMT, такие как белки TGF- $\beta$ и EGFR, были повышены у животных с моделированием воспаления почек путем создания обструкции мочеточника, что связано с направленной сверхэкспрессией ПТГрП в проксимальных канальцах почек. Существующие данные свидетельствуют о том, что ПTГрП, TGF- $\beta$, VEGF, а также активация рецептора эпидермального фактора роста могут действовать совместно посредством активации ERK, модулируя EMT в почечных тубулоэпителиальных клетках (Ardura J.A. et al., 2010). В совокупности эти данные демонстрируют важную роль ПТГрП в фиброгенезе почек благодаря способности этого протеина индуцировать экспрессию белков внеклеточного матрикса, а также путем модуляции ЕМТ в почечных тубулоэпителиальных клетках.

\subsubsection{7. Влияние паратгормон-родственного белка на почечно-клеточный апоптоз и регенерацию почек}

ПТГрП является локально активным фактором, который влияет на апоптоз и пролиферацию во многих типах клеток через паракринные или интракринные пути. Предыдущие исследования показали, что ПТГрП может ингибировать апоптоз в нескольких типах клеток (Cebrián A. et al., 2002; Henderson J. et al., 1995). Meзангиальные клетки (МС) играют ключевую роль как в физиологическом функционировании почечных клубочков, так и при патологических процессах в них. Гломерулонефрит характеризуется пролиферацией и апоптозом мезангиальных клеток. (Ott U.et al., 2007; Liu L. et al., 2012). При экспериментальном гломерулонефрите начальный мезангиолизис, связан с чрезмерным апоптозом МС (Bagchus W.M. et al., 1990). Позднее во время гломерулонефрита апоптоз МС имеет тенденцию уравновешивать избыточную пролиферацию МС. Это заканчивается либо гомеостатическим рубцеванием, либо прогрессированием гломерулосклероза и потерей функции почек (Baker A.J. et al., 1994; Kashihara N. et al., 1999).

Hochane M. et al. (2013) оценили влияние обоих путей влияния ПТГрП на пролиферацию и апоптоз МС. Результаты показали, что 
делеция ПТГрП в МС снижает их пролиферацию и увеличивает апоптоз. Активация PTH1R с помощью ПТГрП (1-36) или ПТГ (1-34) не влияла на пролиферацию, но увеличивалась выживаемость МС. Сверхэкспрессия ПТГрП, не содержащего его последовательности ядерной локализации, защищала клетки от апоптоза без изменения их пролиферации. Индуцированная ПТГрП пролиферация МС была связана с понижающей регуляцией ключевого компонента передачи ингибиторных сигналов, индуцируемых связыванием TGF-b co своими рецепторами, p27Kip1 и повышающей регуляцией транскрипционного фактора, играющего решающую роль в контроле клеточного цикла с-Myc/E2F1. Показано, что делеция ПТГрП повышает уровень белка р27Kip1, а избыточная экспрессия ПТГрП снижает его. p27Кір1 является хорошо известным ингибитором клеточного цикла. ПТГрП увеличивал выживание МС посредством активации путей цАМФ/протеинкиназы А и PI3-K/Akt-киназа. Передача сигналов PI3-K/Akt через внутриклеточный сигнальный путь, центральными компонентами которого являются ферменты фосфоинозитид-3киназа (PI3K) и АКТ-киназа является ключевым механизмом, вовлеченным в выживание клеток (Hanada M. et al., 2004; Manning B.D., Cantley L.C., 2007) способствующим пролиферации клеток посредством фосфорилирования ингибитора CDK p27 и выживанию клеток путем прямого ингибирования проапоптотических белков. Эти результаты показывают, что ПТГрП является полигормоном с множеством ролей в МС, действующим в качестве митогенного фактора через интракринный путь и снижающим апоптоз главным образом через паракринный путь.

Апоптоз считается важным компонентом острого ответа эпителия канальцев на повреждение (Basnakian A.G. et al., 2002; Kaushal G.P. et al., 2004). Предполагаемое ингибирующее действие ПТГрП на апоптоз почечных клеток может оказать существенное влияние на патогенез повреждения почек. Апоптоз участвует в первоначальной потере собственных почечных клеток после острого повреждения почек, но он также может обеспечить баланс инфильтрации мононуклеарными клетками и компенсаторной гиперплазии канальцев в этой ситуации (Lieberthal W., Levine J.L., 1996; Ortiz A. et al., 2001; 
Jones E.A. et al., 2000). Показано, что ПТГрП защищает фибробласты почек, тубулоэпителиальные клетки и клетки карциномы почек от апоптоза, главным образом, через аутокринно/паракринный путь (Ortega A. et al., 2006; Massfelder T. et al., 2004). Установлено, что ПТГрП, взаимодействуя с PTH1R, напрямую действует как фактор выживания почечных тубулоинтерстициальных клеток по двойному механизму, включающему активацию антиапоптотического белка $\mathrm{Bcl}-\mathrm{XL}$ и активацию пути фосфатидилинозитол-3-киназа/Akt/Bad (Ortega A. et al., 2006). Результаты экспериментов с моделированием острого токсического повреждения почек, вызванного фолиевой кислотой с использованием мышей сверхэкспрессирующих ПТГрП позволили предположить, что это действие ПТГрП может иметь пагубные последствия для поврежденной почки. Эти мыши продемонстрировали значительную задержку восстановления почечной функции и более высокие очаговые зоны тубулоинтерстициального фиброза, чем нормальные мыши, связанные с уменьшением апоптотических тубулоинтерстициальных клеток (Ortega A. et al., 2006). Обоснованием этой связи может служить тот факт, что апоптоз интерстициальных фибробластов, по-видимому, является механизмом предотвращения фиброгенеза (Lieberthal W., Levine J.S., 1996; Ortiz A. et al., 2000).

Ardura J.A. et al. (2013) впервые описали участие ПТГрП в регуляция выживаемости клеток в почках, связанную с активацией Runx2, принадлежащего к семейству транскрипционных факторов runt-домена. Продемонстрирована возможная связь между ПТГрП-индуцированной экспрессией Runx2, эффектом повышения выживаемости тубулоэпителиальных клеток почки и апоптозом в эпителиальных клетках почечных канальцев. Runx2 впервые идентифицирован как эффектор антиапоптотического эффекта, связанного с ПТГрП, в эпителиальных клетках канальцев. Экспрессия Runx2 была выявлена в эпителиальных клетках почечных канальцев мыши и человека in vitro (клеточные линии МСТ и НК2) и в почках мыши in vivo. ПТГрП увеличивал экспрессию Runx2 в обеих клеточных линиях в зависимости от дозы и защищал их от апоптоза, вызванного фолиевой кислотой. Ингибирование Runx2 малой интерферирующей 
РНК или доминантно-негативным Runx2 нарушало антиапоптотический эффект ПТГрП на индуцированный фолиевой кислотой апоптоз in vitro. Сверхэкспрессия ПТГрП или ишемически-реперфузионное повреждение приводили к увеличению экспрессии тубулоэпителиального Runx2 у мышей. B предыдущих исследованиях был установлен профибротический, провоспалительный эффект ПТГрП с повышенным интерстициальным фиброзом у мышей с избыточной экспрессией ПТГрП после повреждения почек фолиевой кислотой (Ortega A. et al., 2006). Представлены данные о фенотипическом превращении тубулоэпителиальных клеток в фибробластоподобные по механизму эпителиально-мезенхимальных перехода, индуцированного ПТГрП (Ardura J.A. et al., 2010). Остается неясным, как один и тот же белок, с одной стороны, оказывает антиапоптотический эффект на тубулоэпителиальные клетки, опосредуемый Runx2, a с другой стороны, вызывает переход тубулоэпителиальных клеток в стромальные клетки, способствуя фиброзу почек (Kramann R., Schneider R.K., 2013).

Ишемическое и токсическое повреждение эпителиальных клеток почечных канальцев может вызвать как острую, так и хроническую почечную недостаточность в зависимости от интенсивности и времени воздействия повреждающего фактора (Humes H.D. et al., 1995; Lieberthal W., Levine J.L., 1996). Важное значение имеет пролиферация поврежденных канальцевых клеток для структурного восстановления канальцев и последующего функционального восстановления поврежденной почки. Утверждается, что ПТГрП оказывает влияние на регенераторные процессы в клетках почечных структур. Показано, что мРНК ПТГрП увеличивается вместе со снижением экспрессиигена рецептора PTH1R в корковом веществе почки во время фазы восстановления после ишемического повреждения (Soifer E.N. et al., 1993). Эти данные рассматривались, как свидетельство того, что ПТГрП является аутокринным фактором, который может участвовать в процессах почечной регенерации (Santos S. et al., 1998).

Митогенные особенности ПТГрП и его ранняя сверхэкспрессия после повреждения почек в экспериментальных моделях острой почечной недостаточности, вызванной или ишемией или нефротоксинами, 
первоначально позволили предполагать, что ПТГрП может участвовать в регенеративном процессе после острого повреждения почки (Santos S. et al., 2001; Soifer E.N. et al., 1993), так как при этом было обнаружено быстрое уменьшение экспрессии гена PTH1R. Это резко отличается от эффектов других хорошо охарактеризованных почечных митогенов, таких как эпидермальный фактор роста (EGF) и фактор роста гепатоцитов (HGF), чьи рецепторы активируются после острого повреждения почки (Humes H.D. et al., 1995; Matsumoto K., Nakamura T., 2001). Современные данные свидетельствуют о том, что факторы, отличные от ПТГрП или Ang II, могут быть причиной подавление PTH1R, связанного с повреждением почек (FiaschiTaesch N.M. et al., 2004; Lorenzo O. et al., 2002).

Эффекты ПТГрП как митогена при остром повреждении почек были подвергнуты детальному анализу при рассмотрении целевой доставки ПТГрП в проксимальные канальцы у мышей, которая не обеспечивала защиту почек от повреждения ишемией или фолиевой кислотой (Fiaschi-Taesch N.M. et al., 2004). Кроме того, экспериментальные данные с использованием модели на крысах показала, что предварительная обработка блокаторами Ang II отменяет ПТГрП повышенние экспрессии ПТГрП регуляция, но не тубулярную гиперплазию (Ortega A. et al., 2005). Таким образом, доказана маловероятность того, что ПТГрП играет значительную роль в регенеративном процессе после острого повреждения почек

\subsubsection{8. Паратгормон-родственный белок при хронической диабетической нефропатии}

Конечная стадия почечной недостаточности из-за сахарного диабета, особенно диабета 2 типа, описана как медицинская катастрофа мирового масштаба (Ritz E. et al., 1999). Диабетическая нефропатия (ДН) характеризуется развитием протеинурии и последующего гломерулосклероза, состояниям, которым всегда предшествует развитие раннего гипертрофического процесса в клубочковом компартменте (Wolf G., Ziyadeh F.N., 1999). ДН характеризуется гипертрофией клубочковой и тубулярной структур почек, утолщением базальной мембраны, клубочковой гиперфильтрацией и накоплением 
компонентов внеклеточного матрикса в гломерулярном мезангии (гломерулоосклероз) и тубулярном интерстиции (тубулоинтерстициальный фиброз). Утолщение базальной мембраны, а также расширение мезангиальной матрицы связанны с ухудшением функции клубочков (протеинурия) (Osterby R. et al., 2001; White K.E., Bilous R.W., 2000).

Гипертрофия тубулоэпителиальных, а также клубочковых клеток, включая как висцеральные эпителиальные (подоциты), так и мезангиальные клетки, является ранним признаком поражения почек диабетом (Powers A.C., 2005; Wolf G., 2004). Известно, что при дабете происходит гипертрофия подоцитов, связанная с уменьшением их количества на клубочек (Kriz W. et al., 1998; Mifsud S.A. et al., 2001; Pagtalunan M.E. et al., 1997). Со временем гипертрофия подоцитов может стать неадаптивным ответом, ведущим к гломерулосклерозу. Механизмы, с помощью которых высокое содержание глюкозы (HG) приводит к гипертрофии почечных клеток, до сих пор полностью не изучены. Показано, что гипертрофия, вызванная HG, включает раннюю активацию ренин-ангиотензиновой системы с последующей индукцией TGF- $\beta 1$, что, в свою очередь, активирует регуляторный белок p27Kip1 (Pantsulaia T., 2006; Wolf G. et al., 1998; Xu Z.G. et al., 2005), вовлеченный в ингибирование клеточного цикла с последующим увеличением синтеза клеточного белка (Huang H.C., Preisig P.A., 2000). TGF- $\beta$ признан важным медиатором хронических заболеваний почек, которые характеризуются накоплением внеклеточногоматрикса (ECM) и развитием гломерулосклероза (Böttinger E.P., 2007; LópezHernández F.J., López-Novoa J.M., 2012; Sutariya B. et al., 2016). Гипертрофия мезангиальных клеток является одним из самых ранних морфологических изменений при ДН (Wolf G., Ziyadeh F.N., 1999). Гипертрофированные МС секретируют больше белка ЕСМ, что приводит к расширению мезангиального матрикса (Hu C. et al., 2015). TGF- $\beta$ играет ключевую роль в накоплении ECM (McKay N.G. et al., 1993; Poncelet A.C., Schnaper H.W., 1998; Kolm V. et al., 1996).

В экспериментальном исследовании (Wu S.Z. et al., 2017) было изучено взаимодействие между передачей сигналов ПТГрП и TGF- $\beta 1$ в MC крыс и роль ПТГрП в накоплении ЕСМ. Показано, что воздействие 
ПТГрП значительно увеличило экспрессию белка фибронектина (FN) через 24 часа, в отличие от раннего ингибирующего эффекта на TGF- $\beta 1$ или HG-индуцированную активацию FN. Этот дифференциальный эффект на экспрессию белка FN можно объяснить возвращением как PTH1R, так и рецептора TGF- $\beta$ II типа (T $\beta$ RII) в плазматическую мембрану в этот более поздний момент времени, что позволяет передавать сигналы через эти рецепторы. Установлено, что острое и хроническое системное введение ПТГрП оказывает различное влияние на диабетическую почку. Кратковременное введение ПТГрП может иметь ренопротективные эффекты из-за снижения активности передачи сигналов TGF- $\beta$ при ДН, тогда как хроническое введение ПТГрП способствует накоплению ЕСМ, опосредованному TGF- $\beta 1$. У диабетических крыс короткое воздействие ПТГрП индуцирует интернализацию комплекса PTH1R-T $\beta$ RI и предотвращает HG и TGF- $\beta$-опосредованную активацию $\operatorname{Smad} 2 / 3$ и активацию FN в MC крыс. Однако интернализованные рецепторы возвращаются на поверхность клетки после длительного воздействия ПТГрП и обеспечивают ПТГрП-индуцированную активацию FN. Эти данные продемонстрировали двойную роль ПТГрП в передаче сигналов TGF- $\beta$ и повышающей регуляции ЕСМ в МС. Информация о перекрестном взаимодействии между ПТГрП и TGF- $\beta 1$ в почках представлена данными свидетельствующими, что непрерывная экспрессия или инкубация с ПТГрП индуцирует активацию TGF- $\beta$ в МC и подоцитах (Ortega A. et al., 2012; Romero M. et al., 2010). Сообщалось, что длительное воздействие ПТГрП на культивируемые человеческие MC в отсутствие экзогенных факторов роста вызывает пролиферативный эффект (24 часа) с последующей гипертрофией в течение 72 часов (Ortega A. et al., 2012; Bosch R.J. et al., 1999; Hochane M. et al., 2013), который опосредуется TGF- $\beta 1$ (Ortega A. et al., 2012).

\subsubsection{1. Паратгормон-родственный протеин при экспериментальной диабетической нефропатии}

Используя экспериментальную модель диабетической нефропатии (ДН), индуцированной стрептозотоцином (STZ) Izquierdo A. et al. (2006) изучили возможные изменения в системе ПТГрП/РТН1R, 
связанные с этой патологией почек, для которой характерна начальная фаза почечной гипертрофии как на тубулярном, так и на гломерулярном уровнях, с последующим увеличением экскреции альбумина с мочой (протеинурия) (Gross M.L. et al., 2004). ДН индуцировали у мышей Swiss-CD1 (CD1), а также у мышей со сверхэкспрессией ПТГрП. У мышей с диабетом CD-1 наблюдалось значительное увеличение экспрессии как ПТГрП, так и PTH1R, как на клубочковом, так и на тубулярном уровнях, что связано с увеличением экскреции альбумина с мочой (Izquierdo A. et al., 2006). Умышей-диабетиков со сверхэкспрессией ПТГрП выявлены почечная гипертрофия, значительно более высокий уровень экскреции альбумина с мочой и более низкий уровень общего белка плазмы по сравнению с контрольными животными. Обнаружена значительная связь между почечной экспрессией ПТГрП, РТН1R и экскрецией альбумина с мочой у мышей с диабетом. Кроме того, согласно данным логистического регрессионного анализа, риск развития протеинурии у мышей с более высокими уровнями ПТГрП и PTH1R увеличился в 6 раз. Исследование роли ПТГрП в гипертрофии диабетической почки показали, что ПТГрП играет ключевую роль в механизмах HG-индуцированной гипертрофии подоцитов (Romero M. et al., 2010). Следует отметить, что подоциты считаются терминально дифференцированными клетками и, следовательно, не способны к регенерации in vivo. В этих исследованиях гипертрофия подоцитов, вызванная HG, ингибировалась присутствием специфического антитела, нейтрализующего ПТГрП.

Хотя ПТГрП, по-видимому, не влияет на апоптоз подоцитов, было установлено, что он способен модулировать экспрессию нескольких как позитивных, так и негативных регуляторных белков клеточного цикла. Было показано, что ПТГрП (1-36) стимулирует циклин D1, тем самым способствуя проникновению подоцитов в G1, он также подавляет циклин Е, следовательно, блокируя клеточный цикл позднее в G1. ПТГрП способен активировать регуляторный белок клеточного цикла p27Kip1, который играет ключевую роль в гипертрофии диабетических клеток, предотвращая активацию активности циклина Е и задерживая клеточный цикл в G1 (Huang H.C., Preisig P.A., 2000; Romero M. et al., 2010) обнаружили, что фармакологическая блокада 
PTH1R ингибирует активацию p27Kip1, индуцированную как HG, так и Ang II. Взятые вместе, эти данные предполагают, что ПТГрП может опосредовать гипертрофическую передачу сигналов, действующую аутокринным/интракринным способом через рецептор PTH1R.

Исследование механизма стимуляции p27kip1, индуцированной как ПТГрП, так и TGF- $\beta 1$, позволило Romero M. et al. (2010) установить, что во-первых использование миРНК ПТГрП ингибирует способность HG и Ang II стимулировать активацию p27Kip1, хотя и не может предотвратить активацию TGF- $\beta 1$ этого белка. Во-вторых, в подоцитах, трансфицированных миРНК TGF- $\beta 1$, ПТГрП (1-36) не вызывал избыточную экспрессию р27Kip1 и гипертрофию. Таким образом показано, что TGF- $\beta 1$ опосредует как активацию p27Kip1, так и реакцию гипертрофии, индуцированную ПТГрП в условиях НG. Romero M. et al. (2010) обнаружили, что экспрессия в клубочках как TGF- $\beta 1$, так и p27Kip1 постоянно повышена у мышей со сверхэкспрессией ПТГрП, хотя это не сопровождались почечной гипертрофией (Fiaschi-Taesch N.M. et al., 2004). Умышей со сверхэкспрессией ПТГрП выявили конститутивную активацию различных провоспалительных медиаторов (Rámila D. et al., 2008), включая фактор роста эндотелия сосудов-1 (Ardura J.A. et al., 2008) без доказательств повреждения почек. Эти данные свидетельствуют о том, что ПТГрП может участвовать в повышающей регуляции клубочковых TGF- $\beta 1$ и p27Kip1.

В совокупности эти результаты позволили констатировать, что почечная система ПТГрП/РТН1R активируется при стрептозотоцин-индуцированном диабете у мышей и, по-видимому, связана с почечной гипертрофией и отрицательно влияет на исход ДН (Izquierdo A. et al., 2006). Показано, что ПТГрП играет ключевую роль в механизмах HG-ндуцированной гипертрофии подоцитов (Romero M. et al., 2010), которая подавлялась присутствием специфических антител, нейтрализующих ПТГрП.

\subsubsection{2. Паратгормон-родственный протеин при диабетической нефропатии человека}

Роль ПТГрП при диабетической нефропатии (ДН) человека исследовали используя два экспериментальных подхода (Wolf G., Ziyadeh F.N., 1999). Сначала оценили, может ли ПТГрП повышаться 
в почках у пациентов с ДН. И, во-вторых, проанализировали потенциальную роль ПТГрП в механизмах гипертрофии, вызванной высоким содержанием глюкозы (HG) в культивируемой линии мезангиальных клеток человека. Гипертрофия мезангиальных клеток человека является одной из самых ранних характеристик у пациентов с ДН. Была изучена взаимосвязь сверхэкспрессии ПТГрП в ДН человека и предполагаемая роль этого белка в гипертрофии мезангиальных клеток человека с HG (Ortega A. et al., 2012). Используя иммуногистохимию в срезах почек от пациентов с клиническим и гистопатологическим диагнозом диабетической нефропатии Romero M., et al. (2013) продемонстрировали повышенное канальцевое и клубочковое иммуноокрашивание на ПТГрП и наблюдали интенсивную активацию ПТГрП как в гломерулярных, так и в тубулоэпителиальных клетках, включая ядерную иммунолокализацию в последних клетках. Отмечено, что почки этих пациентов демонстрировали сходную картину иммунолокализации ПТГрП с той, которая наблюдалась ранее на модели диабетических мышей (Romero M. et al., 2010). Этот факт вместе с данными, полученными in vitro в культуре мезангиальных клеток человека, убедительно свидетельствует о том, что ПТГрП может быть важным фактором в гипертрофии мезангиальных клеток у пациентов с диабетом.

Гипертрофия мезангиальных клеток человека в среде с высоким содержанием глюкозы увеличивала экспрессию белка ПТГрП, связанную с развитием гипертрофии. Этот эффект был также индуцирован N-концевым доменом ПТГрП (1-36). Гипертрофия, вызванная HG и ПТГрП (1-36), была связана с увеличением экспрессии белка суclin D1 и p27Kip1, снижением экспрессии сусlin E и предотвращением активации комплекса cyclin E/cdk2. Как нейтрализующая ПТГрП антисыворотка ( $\alpha$-ПТГрП), так и антагонист рецептора PTH1R (JB4250) были способны отменить индукцию гипертрофии HG, вышеупомянутые изменения белков клеточного цикла, а также повышающую регуляцию TGF- $\beta 1$. Более того, способность как HG, так и ПТГрП (1-36) индуцировать гипертрофию мезангиальных клеток человека была отменена $\alpha$-TGF $\beta 1$. Исследования in vitro показали, что длительное воздействие HG на человека 
в отсутствие экзогенных факторов роста вызывает гипертрофию после краткого самоограниченного митогенного эффекта (Sun J. et al., 2010). Установлено, что HG-индуцированная гипертрофия мезангиальных клеток человека была связана с прогрессирующим увеличением экспрессии белка ПТГрП. Кроме того, экзогенный ПТГрП (136) проявляет ранний пролиферативный эффект, за которым следует гипертрофический ответ. Таким образом, ПТГрП, по-видимому, повторяет пролиферативный, а также гипертрофический ответ, индуцированный HG на культивируемых мезангиальных клетках человека (Wolf G., Ziyadeh F.N., 1999).

Изучение механизма, посредством которого ПТГрП (1-36) переключает первоначальный митогенный стимул в гипертрофию, проведено путем оценки экспрессии нескольких регуляторных белков клеточного цикла, которые, как известно, модулируют этот клеточный эффект. Первоначально было показано, что как HG, так и ПТГрП (1-36) воздействуют в мезангиальных клетках человека на клеточный цикл, что связано с увеличением активности как циклинов D1, так и Е и cdk2. Позже только циклин D1 оставался увеличенным вместе с инактивацией циклина E/cdk2. Общепризнанно, что в то время как циклин D управляет физическим ростом клетки, циклин Е определяет, будет ли характер роста почечных клеток гиперплазией (активация циклина Е) или гипертрофией (подавление циклина E) (Wolf G., 2000). Известно также, что ингибитор cdk p27Kip1 играет ключевую роль в механизмах индуцированной HG гипертрофии мезангиальных клеток, регулируя (ингибируя) активность комплекса циклин E/cdk2 (Hengst L., Reed S.I., 1997; Wolf G. et al., 1997). Также показано, что ПТГрП (1-36) способен повышать уровень р27Кір1 таким же образом и по срокам, что и среда HG. Представленные данные убедительно свидетельствуют о том, что HG и ПТГрП (1-36) взаимодействуют с общим клеточным путем, приводящим к гипертрофии в мезангиальных клетках человека (Wolf G., Ziyadeh F.N., 1999).

Потенциальная роль ПТГрП в механизмах HG-индуцированной гипертрофии мезангиальных клеток человека была дополнительно оценена путем наблюдения того, что антагонизация системы ПТГрП 
устраняет связанные с гипертрофией изменений в клеточном цикле (Wolf G., Ziyadeh F.N., 1999). Обнаружено, что ПТГрП также способен стимулировать экспрессию белка TGF- $\beta 1$ и его рецептора типа II в гипертрофированных мезангиальных клетках человека, а нейтрализующее антитело TGF- $\beta 1$ устраняет гипертрофию мезангиальных клеток человека, индуцированную ПТГрП (1-36). Кроме того, блокада системы ПТГрП устраняет активацию TGF- $\beta 1$, но не блокирует его рецептор типа II с помощью HG в этих клетках. В связи с этим было показано, что активация последнего рецептора связана с повышенным TGF- $\beta$-опосредованным ингибированием роста (Nishikawa Y. et al., 1998), тогда как его пониженная экспрессия способствует потере чувствительности к TGF- $\beta$ и повышенной пролиферации некоторых раковыхк леток. (Kadin M.E. et al., 1994; Wang J. et al., 1996). Следовательно, вполне вероятно, что система TGF- $\beta$ также может быть активирована, способствуя гипертрофии мезангиальных клеток человека с помощью ПТГрП-независимого механизма. Эти данные указывают на то, что TGF- $\beta 1$ является нижестоящим медиатором ПТГрП (1-36), в индуцировании гипертрофии мезангиальных клеток человека. Установленные факты свидетельствуют, что ПТГрП активируется в почках пациентов с диабетической нефропатией, а также демонстрируют, что ПТГрП действует в качестве важного медиатора индуцированной HG гипертрофии мезангиальных клеток человека, модулируя регуляторные белки клеточного цикла и TGF- $\beta 1$ (Ortega A. et al., 2012). В совокупности исследования на животных и людях показали, что ПТГрП действует как важный медиатор диабетической почечной гипертрофии посредством механизма, который включает модуляцию регуляторных белков клеточного цикла и TGF- $\beta 1$. Кроме того, ангиотензин II, являющийся критическим фактором в прогрессировании повреждения почек, по-видимому, ответственен за активацию ПТГрП в этих условиях.

\subsubsection{9. Рак почек и паратгормон-родственный протеин}

Эффекты ПТГрП при онкопатологии почек лишь один из многочисленных аспектов этого протеина в биологии рака. Многими исследованиями показано, что ПТГрПпродуцируемый неопластическими тканями человека действует как сложный аутокринный или 
паракринный фактор инвазии, пролиферации и дифференцировки опухоли при злокачественных новообразованиях независимо от его гиперкальциемического эффекта (Höfle G. et al., 2001; Nagataki S. et al., 1995; Luparello C., 2011).

ПТГрП был обнаружен в $95 \%$ случаев карциномы почек, но частота гиперкальциемии при этом составляла всего 14\% (Kitazawa R. et al., 1994). Экспрессию ПТГрП в опухолевых клетках находят при иммуногистохимических исследованиях в 75-95\% случаев рака почки (Gotoh A. et al., 1993; Iwamura M. et al., 1999). Выявлена отрицательная корреляционная взаимосвязь между экспрессией ПТГрП и вероятностью развития метастазов рака почки (Iwamura M. et al., 1999). У больных с высокой интенсивностью гистохимического окрашивания опухолевых клеток продолжительность безрецидивного выживания была значительно меньше. Иммуногистохимическое исследование экспрессии паранеопластических факторов: ПТГрП, эритропоэтина и фактора роста эндотелия сосудов у больных с светлоклеточной карциномой почек позволило выявить их положительную корреляцию между собой и стадией развития опухоли. Продукция ПТГрП, эритропоэтина и фактора роста эндотелия сосудов связаны с прогрессированим карциномы почек. Экспрессия ПТГрП не была связана со степенью дифференцировки опухоли, но продукция эритропоэтина и фактора роста эндотелия сосудов существенно коррелировали со степенью дифференцировки опухоли. Все эти факторы были,более выражены у пациентов с гиперкальциемией (Feng C.C. et al., 2013). Результаты ряда исследований роли ПТГрП в онкогенезе почечноклеточной карциномы позволили обозначить потенциал стратегий таргетирования ПТГрП у человека в качестве терапевтической мишени (Sourbier C., Massfelder T., 2006).

Большинство исследований по стимулирующей пролиферацию и антиапоптотической роли ПТГрП в организме, было выполнено на клеточных модельных системах (Massfelder T. et al., 2004; Talon I. et al., 2006). Обнаружено, что ПТГрП действует как существенный фактор выживания и роста in vitro для линий светлоклеточной почечной карциномы, которые подвергались апоптозу в присутствии ПТГрПнейтрализующих антител и после ингибирования рецептора PTH1R. 
Установлено, что обработка антителами вызывала значительную регрессию опухоли у голых мышей. Показано, что нейтрализующие поликлональные антитела к ПТГрП ингибируют рост клеточных линий рака почки in vitro и in vivo (Talon I. et al., 2006). Кроме того, было обнаружено, что экспрессия и синтез белка ПТГрП подавляются с помощью белка-супрессора опухоли фон Хиппеля-Линдау, являющегося компонентом комплекса U3 убиквитинлигазы, который нацелен на $\alpha$-субъединицы факторов транскрипции HIF-1 и HIF-2 (факторов, индуцированных гипоксией) для разрушения в присутствии кислорода. Когда последний является функционально-инактивированным, как это происходит в 40-80\% случаев традиционного рака почечных клеток, HIF-регулируемые гены, которые кодируют несколько метаболических, ангиогенных и ростовых факторов, сверхэкспрессируются, тем самым влияя на ряд связанных с процессом онкогенеза биологических эффектов. Известно, что светло-клеточный рак почки не поддается лечению в настоящее время и, следовательно, в ракурсе необходимости поиска новых агентов для терапевтического вмешательства, система ПТГрП/рецептор РТH1R рассматривается как многообещающая мишень.

Danilin S. et al. (2009) зафиксировали участие мРНК-связывающего белка HuR в стабилизации мРНК и увеличенной экспрессии ПТГрП в светлоклеточной почечной карциноме. Результаты исследований Agouni A. et al. (2007) показали, что ПТГрП имеет решающее значение для роста почечноклеточного рака человека, ингибируя апоптоз опухолевых клеток. Передача сигналов фосфоинозитид-3киназы (PI3K)-Akt-киназы является ключевым путем для ПТГрПиндуцированного антиапоптотического эффекта, в котором интегрин-связанная киназа (ILK) ответственна за выживание клеток почечноклеточного рака человека. ПТГрП активирует ILK, которая затем действует в качестве фосфоинозитидзависимой киназы 2 или белка-посредника для фосфорилирования Akt-киназы. Это, в свою очередь, активирует транскрипционный ядерный фактор каппа B (NF-кB), как нижестоящую мишень Akt-киназы, регулируемую ПТГрП. Следовательно, ПТГрП является одним из основных факторов, участвующих в конститутивной активации этого пути 
в почечно-клеточном раке человека, независимо от экспрессии генасупрессора фон Гиппеля-Линдау. Таким образом, при почечно-клеточном раке ось PI3K/ILK/Akt/NF-кB является многообещающей мишенью для терапевтического вмешательства.

Повышенный уровень ПТГрП в сыворотке был обнаружен у многих, если не у всех пациентов с почечноклеточными карциномами (RCC) с гиперкальциемией. Gotoh et al. (1993) используя антитела против аминотерминальной (1-34) области, иммуногистохимически показали, что $95 \%$ образцов тканей почечноклеточной карциномы экспрессируют ПТГрП. Burton P.B. et al. (1990) показали, что поликлональное антитело к домену ПТГрП (1-34), ингибирует рост клеточной линии почечноклеточной карциномы человека (клетки SKRC-1), что указывает на то, что ПТГрП является аутокринным ростовым фактором в ткани этой опухоли. Продемонстрировано, что карбокситерминальная область (109-141) ПТГрП экспрессируется в 95\% образцов ткани RCC. Высказано предположение, что в отличие от ПТГрП (1-34), ПТГрП (109-141) может участвовать в торможении роста и таким образом влиять на дифференцировку RCC. Выявлено, что экспрессия ПТГрП (109-141) обратно коррелирует с показателями развития рецидивов RCC (Iwamura M., 1999). Peзультаты этого исследования показали, что ПТГрП (109-141) может быть возможным маркером клеточной дифференцировки и может быть полезным для прогнозирования рецидивов у больных с почечноклеточным раком после радикальной нефрэктомии.

Функциональная инактивация гена-супрессора опухоли фон Гиппеля-Линдау (VHL) встречается в 40-80\% обычных почечноклеточных карцином (RCCs) человека. Недавно показали, что RCC c дефицитом VHL экспрессируют большое количество ПТГрП, который действуя через рецептор PTH1R, играет существенную роль в росте опухоли. Показано также, что экспрессия ПТГрП негативно регулируется продуктами гена VHL (pVHL). ПТГрП рассматривается как фактор выживаемости опухолевых клеток рака почки, его экспрессия негативно регулируется геном фон Хиппель-Линдау (Danilin S. et al., 2009). Talon I. et al. (2006) изучили возможную терапевтическую роль блокирования системы ПТГрП/РТН1R 
при RCC, независимо от статуса VHL и уровней экспрессии ПТГрП. Противоопухолевую активность нейтрализующего ПТГрП антитела и антагониста PTH1R оценивали in vitro и in vivo на панели линий RCC человека, экспрессирующих или не экспрессирующих pVHL. Рост опухолевых клеток и их жизнеспособность in vitro были снижены антителом во всех клеточных линиях на $80 \%$. Эти эффекты были результатом апоптоза. Экзогенно добавленный ПТГрП не оказывал влияния на рост и жизнеспособность клеток, но нивелировал ингибирующее действие антитела. Ингибирование роста было воспроизведено также специфическим антагонистом PTH1R во всех клеточных линиях. In vivo обработка голых мышей, несущих опухоль RKCaki-1, антителом к ПТГрП ингибировала рост опухоли на $80 \%$, вызывая апоптоз. Исследование экспрессии ПТГрП и его рецептоpa PTH1R при раке почки и изучение их ассоциации с появлением костных метастазов у больных показало, что в опухолевых клетках рака почки чаще экспрессируется РТH1R (обнаружен в $43 \%$ наблюдений), чем ПТГрП (выявлен в 21,6\% случаев). Экспрессия PTH1R была благоприятным фактором, предсказывающим увеличение безрецидивной выживаемости больных. Экспрессия ПТГрП у больных раком почки сочеталась как со значительным уменьшением времени до развития метастазов, так и со значительным увеличением частоты развития метастазов в кости. При оценке клинического значения экспрессии рецепторов PTH1R у больных раком почки не было найдено никакой взаимосвязи с прогнозом костного метастазирования (Семенов Н.Н. и соавт., 2011; 2012).

\subsection{4. Закдючитедьные замечания о нефротропных эффектах паратгормон-родственного протеина}

В совокупности представленные результаты показывают, что почечная система ПТГрП/РТН1R активируется при экспериментальном, а также человеческом диабете и связана с почечной гипертрофией и отрицательно влияет на исход диабетической нефропатии. ПТГрП также участвует в гипертрофической передаче сигналов на клубочковых клетках, запускаемой высоким содержанием глюкозы. В этом состоянии Ang II индуцирует активацию ПТГрП, что может 
увеличивать экспрессию TGF- $\beta 1$ и р27Kip1. Эти результаты дают новое понимание потенциала защитных эффектов антагонистов Ang II в диабетической нефропатии, прокладывая путь для новых терапевтических тактик. Активация почечной системы ПТГрП/PTH1R представляет собой частое явление в нескольких экспериментальных нефропатиях. Утверждается, что Ang II является основным индуктором, ответственным за гиперэкспрессию ПТГрП как при острых повреждениях почек, так и при диабетической нефропатии, как медиатора повреждения почек (Ortega A. et al., 2005). В первом случае ПТГрП, по-видимому, способствует прогрессированию повреждения почек за счет увеличения выживаемости тубулоинтерстициальных клеток, способствуя воспалению и фиброгенезу, включая переход эпителия в мезенхиму. При диабетической нефропатии ПТГрП может способствовать почечной гипертрофии и протеинурии. В совокупности имеющиеся данные убедительно подтверждают значение ПТГрП как важного полипотентного фактора при патологии почек и дают новое представление о защитном действии антагонистов Ang II при различных нефропатиях, обозначая пути для новых терапевтических подходов.

Последующие исследования почечных эффектов ПТГрП, как фактора регулирующего функционирование этого органа, могут обеспечить новое понимание физиологии нормальной почки (Esbrit P. et al., 2001), а также роли этого протеина в развитии ее патологических состояний. Это позволит расширить поиск возможностей для создания инновационных, высокоэффективных методов диагностики и лечения заболеваний и повреждений почек, ассоциированных с нефротропными эффектами ПТГрП и выделить потенциал стратегий таргетирования ПТГрП в качестве терапевтической мишени.

\section{2. Мочеточники и паратгормон-родственный протеин}

Через 2 года после нефрэктомии с уретеровезикостомией выполненной в связи с обнаружением переходно-клеточного рака мочеточника у пациента был диагностирован рецидив рака мочеточника с метастазированием в прямую кишку и печень. При повторной госпитализации лабораторное обследование выявило существенно 
повышенные уровени сывороточного кальция (13,9 мг/дл), нефрогенного цАМФ и ПТГрП. Иммуногистохимическое исследование продемонстрировало экспрессию ПТГрП в опухолевых клетках, что позвололо интерпретировать гиперкальциемию, как эффект опосредованный ПТГрП, секретируемого опухолевой тканью. Ранее сообщалось о раке мочеточника, связанном с гуморальной гиперкальциемией злокачественных новообразований, однако этот случай считается первым, связанным с верифицированным повышением ПТГрП (Matsuoka S. et al., 1994).

\section{3. Мочевой пузырь и паратгормон-родственный протеин}

\subsection{1. Вдияние паратгормон родственного протеина на гладкомышечные структуры мочевого пузыря}

Существующие представления о роли паратгормон-родственного протеина в регуляции фукционального состояния мочевого пузыря базируются преимущественно на результатах немногочисленных экспериментальных исследований разных лет. Информация о причастности этого белка к формированию дисфункций мочевого пузыря представлена практически единичными сообщениями. В одном из первых экспериментальных исследований посвященных анализируемому вопросу Yamamoto M. et al. (1992) получили доказательства того, что синтез ПТГрП в ткани гладкой мускулатуры стенки мочевого пузыря индуцируется ее механическим растяжением. Результаты экспериментов с использованием мочевого пузыря крысы в качестве модели расширяемого полого органа свидетельствуют, что уровни мРНК ПТГрП изменяются в ответ на растяжение стенки мочевого пузыря в процессе его наполнения. В нормальных условиях уровни мРНК ПТГрП в мочевом пузыре коррелируют с объемом мочи, и соответственно со степенью растяжения мочевого пузыря.

Если мочевой пузырь in vivo поддерживался пустым, то уровень мРНК ПТГрП постепенно снижался, в то время как при наполнении вследствие накопления мочи, уровень мРНК ПТГрП резко возрастал. Когда растяжение ограничивалось только частью мочевого пузыря, увеличение мРНК ПТГрП наблюдалось только в растянутой его части. Это позволило авторам сделать заключение, что роль ПТГрП 
в контроле сократимости стенки мочевого пузыря обеспечивается по принципу отрицательной обратной связи.

Всесторонний анализ экспрессии генов в модели функции накопления и опорожнения мочевого пузыря in vivo имеет потенциальные преимущества перед моделью in vitro, поскольку при этом учитываются как прямые рефлекторные, так и косвенные факторы, влияющие на транскрипционные изменения в мочевом пузыре, и в том числе растяжение мышц, изменение иннервации, гипоксию и гипоперфузию. Использование этой модели позволило подтвердить факт индукции экспрессии гена ПТГрП растяжением мочевого пузыря (Yamamoto M. et al., 1992). Важным результатом данного исследования явилась констатация того, что рецепторы, с которыми взаимодействует ПТГрП, преимущественно локализованы в гладкой мускулатуре детрузора где происходит одновременно продукция ПТГрП, что указывает на возможность регуляторного воздействия этого протеина аутокринным и паракринным путем на гладкую мускулатуру.

Эти исследования продемонстрировали, что уротелий не является основной мишенью для ПТГрП, поскольку в нем присутствует небольшое количество PTH1R-рецепторов и уровень ПТГрП остается постоянно небольшим при наполнении мочевого пузыря. Авторы исследования заключили, что взаимодействие протеина ПТГрП с PTH1R-рецептором может индуцировать релаксацию гладкой мышцы детрузора в мочевом пузыре и эффекты ПТГрП реализуются через сигнальный путь аденилатциклаза-сАМФпротеинкиназа А. Другой вывод этого исследования состоит в том, что ПТГрП сильно подавляет спонтанное сокращение гладких мышц мочевого пузыря, проявляя лишь незначительное ингибирующее действие на холинергически-индуцированное сокращение мочевого пузыря. Иммуногистохимические исследования, проведенные в ткани растянутого мочевого пузыря, указывают на наличие иммунореактивности ПТГрП в клетках гладкой мускулатуры. Реактивность мочевого пузыря in vitro на экзогенный ПТГрП зависела от состояния мочевого пузыря in vivo на момент эксцизии. В мышечных полосках, полученных из опорожненного in vivo мочевого пузыря, ПТГрП-(1-34)-NH2 расслаблял сокращение детрузора, 
индуцированное карбахолом, дозозависимым образом, но не оказывал влияния на сокращение мышечных образцов из наполненного in vivo мочевого пузыря, которые имели высокую эндогенную экспрессию ПТГрП (Yamamoto M. et al., 1992).

Установлено, что экспрессия мРНК ПТГрП и рецептора с которым ПТГрП специфически связывается (PTH1R-рецептор) доминирует в гладкой мускулатуре мочевого пузыря где уровень мРНК ПТГрП был более чем в 6 раз, а мРНК РTH1R-рецептора в 4,4 раза выше чем в уротелии (Turner P.R. et al., 1998). В отличие от динамических изменений уровней ПТГрП, экспрессия транскрипта PTH1R-рецептора оставалась относительно стабильной при растяжении мочевого пузыря. Показано, что секреция ПТГрП, индуцируемая в мочевом пузыре вследствие его растяжения, препятствует спонтанному сокращению гладкой мускулатуры детрузора, имеющей PTH1R-рецептор, а также уменьшает амплитуду сокращения мочевого пузыря. Эти данные свидетельствуют о физиологическом значении взаимодействия ПТГрП с PTH1R-рецептором в регуляции функции мочевого пузыря (Daifotis A.G. et al., 1992; Nishikawa N. et al., 2013).

Подтверждено присутствие в мочевом пузыре ПТГрП-иммунореактивности, увеличивающейся в ответ на его растяжение (Steers W.D. et al., 1998). Гипотеза о том, что продукция ПТГрП может быть увеличена исключительно растяжением, а не другими возможными переменными in vivo была проверена путем растяжения клеток гладкой мускулатуры мочевого пузыря и анализа культуральной среды для этого белка. В ответ на механическое растяжение секреция ПТГрП увеличилась в культуре клеток гладких мышц. Иммунорадиометрический анализ показал максимальные показатели

секреции в течение первых восьми часов. Ингибитор синтеза белка циклогексимид ингибировал базальную и индуцированную растяжением секрецию ПТГрП. Констатировано, что повышенная секреция ПТГрП в ответ на растяжение гладких мышц является компонентом аутокринного действия, расслабляющего мочевой пузырь во время наполнения. Предполагается, что ПТГрП также может оказывать паракринное действие на сосуды, регулирующие кровоток во 
время наполнения мочевого пузыря, или может модулировать нейронную активность (Steers W.D. et al., 1998).

Нейрогуморальную модуляцию сократимости слизистой оболочки мускулатуры мочевого пузыря морских свинок в сопоставлении с мышечной недостаточностью детрузора продемонстрировали в недавней работе Lee K. et al. (2016). Мышечные структуры собственной пластинки слизистой оболочки располагались преимущественно параллельно с кровеносными сосудами. Хотя РTH1R-рецепторы экспрессировались как в детрузоре, так и в слизистой оболочке, экзогенный ПТГрП (1 нМ) подавлял спонтанные сокращения в детрузоре, но не в слизистой оболочке. Для ингибирования

сократимости слизистой оболочки потребовалась более высокая концентрация ПТГрП (10 нМ). Капсаицин (1 мкM) отменил спонтанные сокращения в слизистой оболочке, но имел возбуждающее действие на сократительную способность детрузора. Совместная локализация мускулатуры слизистой оболочки с субуротелиальными микроциркуляторными структурами стенки мочевого пузыря предполагает, что спонтанные сокращения слизистой оболочки могут функционировать, чтобы предотвратить растяжение микрососудов при раслаблении стенки мочевого пузыря во время фазы накопления. Вероятно, именно ПТГрП избирательно подавляет спонтанные сокращения в детрузоре, но не в слизистой оболочке. Таким образом, эндогенный ПТГрП может значительно увеличивать наполнение мочевого пузыря без связанной с растяжением деформации сосудистых структур слизистой оболочки (Lee K. et al., 2016).

Nishikawa N. etal. (2013) исследовали физиологическую роль ПТГрП в модели острого расширения мочевого пузыря у самок крыс. Растяжение мочевого пузыря, вызванное инфравезикулярной обструкцией, является часто встречающимся в урологической практике патофизиологическим состоянием, которое вызывает различные морфологические и функциональные изменения в мочевоом пузыре, включая ремоделирование матрикса, мышечную гипертрофию, декомпенсацию сократительной функции мочевого пузыря и его гиперактивность (Imamura M. et al., 2007; Imamura M. et al., 2009; Okutsu H. et al., 2011). Механическое растяжение гладкой мышцы 
(Adam R.M. et al., 2004; Yang R. et al., 2008) а также гипоксия с гипоперфузией (Okutsu H. et al., 2011; Saito M. et al., 2010) и другие стрессоры могут вызывать транскрипционные изменения, которые в конечном итоге приводят к миогенным изменениям в функции мочевого пузыря (Brading A.F., 1997).

В эксперименте на крысах доказано, что спонтанное сокращение нормального мочевого пузыря является очень локализованным асинхронным процессом (Hashitani H. et al., 2004), но оно становится более синхронизированным и имеет большую амплитуду после пересечения спинного мозга (Ikeda Y. et al., 2007) и обструкции мочеиспускательного канала (Drake M.J. et al., 2003). Такое спонтанное сокращение вызывает воспаление афферентного нерва в мочевых пузырях с гиперактивностью детрузора (McCarthy C.J. et al., 2009) и может лежать в основе аномального увеличения внутрипузырного давления (Meng E. et al., 2008). Ремоделирование мышц при острой или хронической обструкции мочеиспускательного канала часто связано с чрезмерной активностью детрузора при повышенной мышечной возбудимости и сократимости (Imamura M. et al., 2009; Okutsu H. et al., 2011).

ПТГрП может уравновешивать и уменьшать увеличенную сократимость мышц, чтобы избежать повреждения клеток, вызванного чрезмерным растяжением или метаболическим дисбалансом. Таким образом, ПТГрП является мощным эндогенным релаксантом сокращения мочевого пузыря, а аутокринный или паракринный механизм этого ПТГрП-индуцированного эффекта является физиологически релевантным путем, функционирующим в мочевом пузыре. Активацию взаимодействия ПТГрП с его специфическим рецептором PTH1R предлагается рассматривать как потенциальный терапевтический подход для лечения патологических состояний, связанных с чрезмерной активностью детрузора или обусловленных снижением сократительной функции развивающейся вследствие инфравезикальной обструкции (Nishikawa N. et al., 2013).

В экспериментах на новозеландских белых кроликах PerezMartinez F.C. et al. (2009) моделировали временную частичную обструкцию мочевого пузыря на 4-недельный срок с последующим устранением обструкции и исследованием продукции и локализации 
ПТГрП в различные сроки. Продукция и локализация ПТГрП были выявлены в мышцах и слизистой оболочке мочевого пузыря при помощи иммуногистохимичесих реакций с использованием ПТГрПспецифического антитела (Katazawa S. et al., 1992). В контрольной группе наблюдалась низкая экспрессия ПТГрП как в слизистой оболочке мочевого пузыря, так и в мышечных слоях. После 4-недельной обструкции у экспериментальных животных в мышцах и слизистой оболочке мочевого пузыря экспрессия ПТГрП была соответственно в 3,5 и в 2 раза выше, чем в контроле. Выраженное иммуногистохимическое окрашивание ПТГрП сохранялось в мышечном слое через 4 недели после снятия обструкции, но оно возвращалось к контрольному уровню через 8 недель после устранения обструкции. В слизистой оболочке, уровень ПТГрП возвращался к контрольному уровню через 4 недели. Это исследование показало, что ПТГрП увеличивается даже после временной обструкции мочеиспускательного канала и нормализуется после устранения инфравезикальной обструкции.

Таким образом существующая информация о взаимосвязи фукционального состояния мочевого пузыря и продукции в его структурах ПТГрП получена преимущественно в экспериментальных исследованиях. В единичных клинических исследованиях проводилось иммуногистохимическое выявление пептидных фрагментов ПТГрП в тканях нейропатического мочевого пузыря у пациентов с травмой спинного мозга. Показано, что в переходном эпителии нейрогенного мочевого пузыря выявляется повышенное положительное иммуногистохимическое окрашивание для ПТГрП (43-52) и, в меньшей степени для ПТГрП (127-138) по сравнению с уротелием здоровых добровольцев (Vaidyanathan S. et al., 1999). В другом исследовании иммуногистохимически выявляли присутствие ПТГрП в нормальной слизистой оболочке мочевого пузыря в контрольных случаях, в гиперпластическом переходном эпителии и при плоскоклеточной метаплазии в нейрогенном мочевом пузыре. Контрольная группа состояла из архивных биопсий, взятых при отсутствии патологии мочевыделительной системы. В контрольной группе переходный эпителий не показал иммунного окрашивания. Положительное иммуноокрашивание ПТГрП (1-34) наблюдалось в нейрогенных мочевых 
пузырях во всех биоптатах при нормальном строении переходного эпителия, в $85 \%$ биоптатов при гиперпластическом переходном эпителии и в $80 \%$ случаев при плоскоклеточной метаплазии уротелия. По мнению авторов это наблюдение открывает возможности для разработки инновационной терапии с использованием ПТГрП или его аналогов для коррекции нейрогенной дисфункции мочевого пузыря (Vaidyanathan S. et al., 2000).

Релаксация мышцы детрузора является фундаментальным условием нормального функционирования мочевого пузыря. Несостоятельность этого релаксационного механизма вызывает ухудшение состояния верхних мочевых путей в результате аномального повышения внутрипузырного давления (Ozkan B. et al., 2005). Такая патология обычно наблюдается в случаях с врожденными заболеваниями позвоночника или аномалиями развития мочевых путей, приводящими к инфравезикальной обструкции. Вышеприведенные данные литературы свидетельствуют, что ПТГрП является уникальным эндогенным релаксантом детрузора, который осуществляет свою функцию через PTH1R-рецепторы, локализованные в мышечной стенке мочевого пузыря. Предполагается, что подавление связывания ПТГрП с PTH1R-рецепторами может быть одним из элементов патогенеза заболеваний мочевого пузыря.

Экспрессия ПТГрП-рецепторов в биоптатах мочевых пузырей без патологии и в мочевых пузырях после аугментационной пластики была исследована в отделении урологии Токийского женского медицинского университета (Nishikawa N. et al., 2015). Авторы установили, что цитоплазма мышечных клеток детрузора и кровеносных сосудов в контрольной группе окрашивается положительно на PTH1R-рецепторы. Во всех аугментированных мочевых пузырях выявлено отрицательное окрашивание к PTH1R-рецепторам в гладкомышечных клетках детрузора. Однако в большинстве образцов после аугментации выявлялось положительное окрашивание в мышечной стенке кровеносных сосудов. Если экспрессия PTH1R-рецепторов незначительна, то такой мочевой пузырь может не реагировать на эндогенный ПТГрП, который функционирует как защитный релаксант против чрезмерного растяжения. Таким образом, изменение экспрессии 
PTH1R-рецепторов может быть одной из причин избыточной емкости мочевого пузыря (Nishikawa N. et al., 2015). Что касается функциональной роли оси ПТГрП-РТН1R-рецептор в мочевом пузыре, то не только уровень экспрессии ПТГрП, но и его рецептора вероятно в существенной мере влияют на функционирование и нормального и больного мочевого пузыря. Таким образом, нарушение взаимодействия ПТГрП с его специфическим рецептором может быть вовлечено в патофизиологические реакции мочевого пузыря (Nishikawa N. et al., 2015).

Вышеприведенная информация о взаимосвязи функционального состояния мочевого пузыря и ПТГрП представлена в немногочисленных публикациях, содержащих результаты экспериментальных и клинических исследований. По мнению большинства процитированных авторов эффекты этого белка обеспечиваются посредством паракринных механизмов. О системных влияниях ПТГрП на функционирование мочевого пузыря в литературе, доступной авторам этого раздела монографии, сведения отсутствуют. Роль ПТГрП в патогенезе нарушений сократительной функции мочевого пузыря проанализирована в недавнем обзоре (Медведев В.Л., Курзанов А.Н., 2018), в котором впервые выдвинуто предположение о том, что к числу причин, способствующих формированию функциональной недостаточности мочевого пузыря можно также отнести влияние на мышечные структуры детрузора хронически повышенного содержания ПТГрП, циркулирующего в кровотоке. Это предположение базируется на сопоставлении вышеописанных эффектов ПТГрП на функциональное состояние мочевого пузыря, продемонстрированных как в эксперименте, так и в немногочисленных клинических исследованиях, а также на данных о системных влияниях ПТГрП на гладкомышечные структуры других органов и тканей.

\subsection{2. Паратгормон-родственный протеин и рак мочевого пузыря}

Установлено, что клетки рака мочевого пузыря продуцируют ПТГрП. Chaudhary U.B. et al. (2004) опубликовали данные о случае переходно-клеточной карциномы мочевого пузыря с документированной гиперпродукцией ПТГрП. Повышенное содержание ПТГрП в кровотоке, как известно, может индуцировать развитие 
паранеопластического синдрома гиперкальциемии. Существующие данные позволили предположить, что ПТГрП явился причиной гуморальной гиперкальциемии злокачественных опухолей у пациентов с раком мочевого пузыря. (Yoshida T. et al., 1994; Maeda Y. et al., 1997). Высокий уровень сывороточного ПТГрП и гиперкальциемия были выявлены у пациента с раком мочевого пузыря примерно через 25 месяцев после цистэктомия и последующей химиотерапии. Инфузия диуретиков, кальцитонина и динатрий памидроната для лечения гиперкальциемии оказались малоэффективными (Akashi T. et al., 1999).В недавней публикации Ando T. et al. (2018) сообщили о случае высоко резистентной к существующей терапии тяжелой гиперкальциеми, связанной с метастазами в лимфатические узлы после радикальной цистэктомии при раке мочевого пузыря.

В научной литературе представлены очень интересные данные о случаях рака мочевого пузыря с одновременной продукцией ПТГрП и гранулоцитарного колониестимулирующего фактора (G-CSF), который стимулирует рост и дифференцировку нейтрофильных гранулоцитов, что приводит к выраженному лейкоцитозу без какой-либо инфекции. Лейкемоидные реакции и гиперкальциемия являются распространенными признаками малигнизации. Они запускаются аберрантной экспрессией G-CSF и ПТГрП, которые секретируются опухолевыми клетками. В одной трети случаев рака уротелия с паранеопластическими синдромами гиперкальциемия сосуществует с лейкемоидными реакциями, вызванными G-CSF (Turalic H. et al., 2006). Опухоли, приводящие к паранеопластическим синдромам, обычно имеют очень злокачественный фенотип и связаны с плохим прогнозом. Большинство опухолей, связанных с лейкоцитозом и гиперкальциемией, представляют собой плоскоклеточные карциномы, клетки которых продуцируют G-CSF и ПТГрП, возможно, из-за того, что оба эти фактора продуцируются кератиноцитами. G-CSF-индуцированный лейкоцитоз и ПТГрП-ассоциированная гиперкальциемия являются паранеопластическими синдромами, связанными с высокой степенью агрессивности опухоли и плохим клиническим исходом. (Hirasawa K. et al., 2002; Hoshi S. et al., 2018). Представляется вероятным, что и G-CSF, и ПТГрП были совместно экспрессированы 
в одних и тех же клетках. Допускается вероятность того, что один из этих биологически активных факторов может способствовать продукции другого (Ueno M. et al., 2000). Эти предположения получили убедительное подтверждение в создание клональной клеточной линии, продуцирующей гранулоцитарный колониестимулирующий фактор и ПТГрП. Цепная реакция с обратной транскрипционной полимеразой выявила присутствие мРНК G-CSF и ПТГрП в этой клеточной линии. У голых мышей, которым трансплантировали клетки этой линии, также были обнаружены лейкоцитоз и гиперкальциемия с высоким уровнем G-CSF и ПТГрП в сыворотке крови (Asahi Y. et al., 1996).

Поиск в базе данных MEDLINE показал, что за последние 20 лет было зарегистрировано семь случаев рака уротелия, продуцирующего ПТГрП и G-CSF. Одновременное производство как G-CSF, так и ПТГрП клетками рака мочевого пузыря зафиксировано в ссобщениях (Kamai T. et al., 1999; Ueno M. et al., 2000; McRae S.N. et al., 2001; Vaidyanathan S. et al., 2002). Tsuchiya F. et al. (2001) описали случай переходно-клеточной карциномы мочевого пузыря у пожилой пациентки лабораторное обследование которой показало выра-

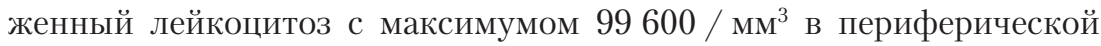
крови и высоким уровнем G-CSF 70 пг/мл в сыворотке (в норме: менее 9,8 пг/мл). Содержание ПТГрП в крови превышало соответствующий показатель нормы почти в 15 раз. Опухолевые клетки были положительными в отношении иммуногистохимического окрашивания как на G-CSF так и на ПТГрП.

Rink M. et al. (2009) сообщили о хорошо документированном случае сверхэкспрессии ПТГрП и G-CSF, при плохо дифференцированной карциноме мочевого пузыря высокой степени агрессивности с паранеопластическим повышением уровня G-CSF и ПТГрП и существенным увеличением уровня кальция и лейкоцитов в сыворотке крови. В работе Kato T. et al. (2016) представлены данные о наличии у 38-летней японской пациентки с раком мочевого пузыря одновременно трех паранеопластических синдромов: ПТГрП-индуцированной гиперкальциемии, лейкоцитоза, вызванного продукцией G-CSF и синдрома Труссо, который в литературе определяют как «синдром гиперкоагуляции, связанный с раком» или «тромбоэмболия, связанная 
со злокачественными новообразованиями» (Varki A., 2007; Bick R.L., 2003). Результаты лабораторных исследований выявили высокий уровень тромбоцитов и повышенный уровень фибриногена. Результаты других исследований системы коагуляции были в пределах нормы. Лабораторные данные также зафиксировали выраженный лейкоцитоз и гиперкальциемию, а также значительно повышенные уровни G-CSF и особенно ПТГрП в сыворотке крови. Иммуногистохимическое исследование образцов ткани инвазивного, слабодифференцированного уротелиального рака выявило положительное окрашивание на G-CSF, которое было очаговым или диффузно-положительным и рассеянную сильную иммунореактивность на ПТГрП. Это первый зарегистрированный случай одновременного формирования нескольких опаснейших паранопластических синдромов у пациентки с раком мочевого пузыря.

Самое последнее из зафиксированных в базе данных MEDLINE сообщений содержит информацию о раке мочевого пузыря, опухолевые клетки которого продуцировали бета-хорионический гонадотропин человека, антиген плоскоклеточной карциномы, гранулоцит-колониестимулирующий фактор и ПТГрП (Hoshi S. et al., 2018). 71-летняя пациентка перенесла радикальную цистэктомию по поводу мышечно-инвазивного рака уротелия. Вскоре после операции у больной появились лейкемоидная реакция и гиперкальциемия и были повышены сывороточные уровни гранулоцитарно-колониестимулирующего фактора, ПТГрП, и бета-хорионического гонадотропина человека, а также положительный результат на антиген сывороточного плоскоклеточного рака. Это первое сообщение о раке мочевого пузыря, который дал положительный результат на четыре опухолевых маркера. Полученные данные подтверждают идею о том, что слабодифференцированные карциномы мочевого пузыря могут эктопически секретировать множество белков, вызывая плейотропные паранеопластические синдромы.

Информация о взаимосвязи ПТГрП и онкопатологии мочевого пузыря, представленная в данном разделе главы, охватывает практически весь период исследования рассматриваемого вопроса и почти все существующие в мире публикации, которых очень немного. 
Анализ цитируемых работ позволяет в целом заключить, что гиперпродукция ПТГрП и ассоциированная с ней гиперкальциемия характерны для агрессивного фенотипа развития рака мочевого пузыря, свидетельствующими о высокой тяжести течения заболевания и связаны с плохим прогнозом у пациентов.

\section{Питература к главе 1}

1. Abbate M., Zoja C., Rottoli D., Corna D., Tomasoni S., Remuzzi G. Proximal tubular cells promote fibrogenesis by TGF-beta1-mediated induction of peritubular myofibroblasts. Kidney Int 2002; 61: 2066-77.

2. Abdulkader, R.C., Yuki, M.M., Paiva, A.C., \& Marcondes, M. (1988). Prolonged inhibition of angiotensin II attenuates glycerol-induced acute renal failure. Brazilian Journal of Medical and Biological Research, Vol. 21, № 2, pp. 233-239.

3. Adam R.M., Eaton S.H., Estrada C. et al. Mechanical stretch is a highly selective regulator of gene expression in human bladder smooth muscle cells. Physiol Genomics. 2004; 15; 20(1): 36-44.

4. Agouni, A.; Sourbier, C.; Danilin, S.; Rothhut, S.; Lindner, V.; Jacqmin, D.; Helwig, J.J.; Lang, H.; Massfelder, T. Parathyroid hormone-related protein induces cell survival in human renal cell carcinoma through the PI3K Akt pathway: evidence for a critical role for integrin-linked kinase and nuclear factor kappa B. Carcinogenesis 2007, 28, 1893-1901.

5. Akashi T., Muraishi Y., Mizuno I., Nagakawa O., Okumura A., Iwasaki M., Fuse H. Bladder cancer and penile cancer with high serum level of PTHrP: A report of two cases. Nishinihon Journal of Urology 1999; 61(5): 448-451.

6. Al Kalbani N., Frieling M., Teh J.C., Harvey E., Geary D.F. Idiopathic hypercalcemia in infants with renal dysplasia. Clin Nephrol. 2011; 75(5): 466-71.

7. Allison, E.T., Drucker, D.J. Parathyroid hormone-like peptide shares features with members of the early response gene family: Rapid induction by serum, growth factors, and cycloheximide. Cancer Res. 1992; 52: 3103-3109.

8. Allred, A.J., Chappell, M.C., Ferrario, C.M., \& Diz, D.I. (2000). Differential actions of renal ischemic injury on the intrarenal angiotensin system. American Journal of Physiology. Renal Physiology, Vol. 279, № 4, (October 2000), pp. F636-F645. 
9. Amizuka N., Lee H.S., Kwan M.Y., Arazani A., Warshawsky H., Hendy G.N., Ozawa H., White J.H., Goltzman D. Cell-specific expression of the parathyroid hormone (PTH)/PTH-related peptide receptor gene in kidney from kidney-specific and ubiquitous promoters. Endocrinology. 1997 138: 469-81.

10. Ando T., Akiyoshi Katagiri, Ryo Nakayama, et al. Hypercalcemia associated with lymph node metastasis following radical cystectomy for bladder cancer. IJU Case Reports. 2018, Vol. 1, № 1, p. 25.

11. Ardura J.A., Rayego-Mateos, S., Rámila D., Ortega-Ruiz, M., \& Esbrit P. (2010). Parathyroid hormone-related protein promotes epithelial-mesenchymal transition. Journal of the American Society of Nephrology. 2010; 21(2): 237-248.

12. Ardura, J.A., Berruguete, R., Rámila, D., Álvarez-Arroyo, V., Esbrit, P. (2008). Parathyroid hormone-related protein interacts with vascular endothelial growth factor to promote fibrogenesis in the obstructed mouse kidney. American Journal of Physiology. Renal Physiology, Vol. 295, № 2, (June 2008), pp. F415-F425.

13. Ardura, J.A., Sanz, A.B., Ortiz, A. et al. Parathyroid hormone-related protein protects renal tubuloepithelial cells from apoptosis by activating transcription factor Runx2. Kidney Int. 2013; 83: 825-834.

14. Asahi, Y., Kubonishi, I., Imamura, J. et al. Establishment of a clonal cell line producing granulocyte colony-stimulating factor and parathyroid hormone-related protein from a lung cancer patient with leukocytosis and hypercalcemia. Jpn. J. Cancer Res. 1996; 87: 451-458.

15. Atchison D.K., Westrick E., David L. Szandzik, Kevin L. Gordish, William H. Beierwaltes. Parathyroid hormone-related protein stimulates plasma renin activity via its anorexic effects on sodium chloride intake. American Journal of Physiology. Endocrinology and Metabolism. 2012; 303: 4: E457-463. 10.1152/ajpendo.00020.2012.

16. Aya K., Tanaka H., Ichinose Y., Kobayashi M., Seino Y. Expression of parathyroid hormone-related peptide messenger ribonucleic acid in developing kidney. Kidney Int. 1999; 55(5): 1696-1703.

17. Bagchus W.M., Jeunink M.F., Elema J.D. The mesangium in antiThy-1nephritis.Influx of macrophages, mesangial cell hypercellularity, andmacromolecular accumulation.Am J Pathol. 1990; 137: 215-223. 
18. Baker A.J., Mooney A., Hughes J., Lombardi D., Johnson R.J., Savill J. Mesangial cell apoptosis: the major mechanism for resolution ofglomerular hypercellularity in experimental mesangial proliferativenephritis. J Clin Invest. 1994; 94: 2105-2116.

19. Basnakian A.G., Kaushal, G.P., \& Shah, S.V. (2002). Apoptotic pathways of oxidative damage to renal tubular epithelial cells. Antioxidant \& Redox Signaling, Vol. 4, № 6, (2002), pp. 915-924.

20. Benigni, A. and Remuzzi, G. Glomerular protein trafficking and progression of renal disease to terminal uremia. Semin Nephrol. 1996; 16: 151-159.

21. Bick R.L. Cancer-associated thrombosis. N Engl J Med. 2003; 349:109-111. doi: 10.1056/NEJMp030086.

22. Bonventre, J.V. (2003). Dedifferentiation and proliferation of surviving epithelial cells in acute renal failure. Journal of the American Society of Nephrology, Vol. 14, № Suppl 1, (2003), pp. S55-S61.

23. Border W.A., Noble N.A. TGF-beta in kidney fibrosis: a target for gene therapy. Kidney Int 1997; 51: 1388-96.

24. Bosch R.J., Ortega A., Izquierdo A., I. Arribas, J. Bover, and P. Esbrit, A transgenic mouse model for studying the role of the parathyroid hormone-related protein system in renal injury // Journal of Biomedicine and Biotechnology, vol. 2011, Article ID 290874, 7 pages, 2011.

25. Bosch R.J., Arenas M.I., Romero M., Nuria Olea, Adriana Izquierdo, Arantxa Ortega, Esperanza Vélez, Jordi Bover, Juan C. Ardura,Esbrit P. (10th 2012). Parathyroid Hormone-Related Protein as a Mediator of Renal Damage: New Evidence from Experimental as well as Human Nephropathies, Chronic Kidney Disease and Renal Transplantation, Manisha Sahay, IntechOpen, DOI: 10.5772/25518.

26. Bosch R.J., Rojo-Linares P., Torrecillas-Casamayor G., IglesiasCruz M.C., Rodríguez-Puyol D. and Rodríguez-Puyol M. (1999) Effects of parathyroid hormone-related protein on human mesangial cells in culture. Am. J. Physiol.1999; 277, E990-E995.

27. Bosch R.J., Rodríguez-Puyol D., Bover J., Rodríguez-Puyol M. Parathyroid Hormone-Related Protein: Roles in the Glomerulus. Exp Nephrol 7(3): 212-216, 1999. DOI: 10.1159/000020604.

28. Böttinger E.P. TGF-beta in renal injury and disease. Semin. Nephrol. 2007; 27: 309-320. 
29. Bowden S.J., Emly J.F., Hughes S.V., Powell G., Ahmed A., Whittle M.J., Ratcliffe J.G., Ratcliffe W.A. Parathyroid hormone-related protein in human term placenta and membranes. J Endocrinol. 1994 Aug; 142(2): 217-24.

30. Brading A.F. A myogenic basis for the overactive bladder. Urology. 1997 Dec; 50(6A Suppl): 57-67; discussion 68-73.

31. Braun K., Atmanspacher F., Schreckenberg R., Grgic I., Schlüter K-D., Effect of free running wheel exercise on renal expression of parathyroid hormone receptor type 1 in spontaneously hypertensive rats, Physiological Reports. 2018; 6(17): e13842. doi.org/10.14814/ phy2.13842.

32. Burtis W.J., Wu T., Bunch C. et al. Identification of a novel 17,000-dalton parathyroid hormone-like adenylatecyclase-stimulating protein from a tumor associated with humoral hypercalcemia of malignancy. J Biol Chem. 1987; 262: 7151-7156.

33. Burton PB., Moniz C., Quirke P., Tzannatos C., Pickles A., Dixit M., Triffit JT., Jueppner H., Segre GV., Knight D.E. Parathyroid hormone-related peptide in the human fetal uro-genital tract. Mol. Cell. Endocrinol. 1990; 69: R13-R17.

34. Burton P.B.J., Moniz C., Quirke P., Malik A., Bui T.D., Jueppner H., Segre G.V., Knight D.E.: Parathyroid hormone-related peptide: Expression in fetal and neonatal development. J Pathol. 1992; 167: 291-296.

35. Burton, P.B.J., Moniz, C., Knight, E. Parathyroid hormone-related peptide can function as an autocrine growth factor in human renal cell carcinoma. Biochem Biophys Res Commun. 1990; 167: 1134-1138.

36. Campos R.V., Asa S.l., Drucker D.J. Immunocytochemical localization of parathyroid hormone-like peptide in the rat fetus. Cancer Res. 1991; 51: 6351-6357.

37. Canario A.V.M., Rotllant J., Fuentes J., Guerreiro P.M., Rita Teodosio H., Power D.M., Clark M.S. Novel bioactive parathyroid hormone and related peptides in teleost fish. FEBS Lett.2006, 580: 291-299.

38. Cardoso J.C., Felix R.C., Power D.M. Nematode and arthropod genomes provide new insights into the evolution of class 2 B1 GPCRs. PLoS One (2014) 9: e92220. doi:10.1371/journal.pone.0092220. 
39. Cebrián, A., García-Ocaña, A., Takane, K.K., Sipula, D., Stewart, A.F., \& Vasavada, R.C. (2002). Overexpression of parathyroid hormone-related protein inhibits pancreatic beta-cell death in vivo and in vitro. Diabetes, Vol. 51, № 10, (2002), pp. 3003-3013

40. Chaudhary U.B., Milling D.L., Bissada N.K. Transitional cell carcinoma of the bladder producing parathyroid hormone-related protein (PTHrP). Can J Urol 2004; 11(1): 2136-8.

41. Chevalier, R.L. Obstructive nephropathy: towards biomarker discovery and gene therapy. Nature Clinical Practice. Nephrology. 2006; 3(2): 157-168.

42. Clemens T.L., Cormier S., Eichinger A., Endlich K., FiaschiTaesch N., Evelyne Fischer, Peter A Friedman, Andrew C Karaplis, Thierry Massfelder, Jérôme Rossert, Klaus-Dieter Schlüter, Caroline Silve, Andrew F Stewart, Karen Takane, Jean-Jacques Helwig. Parathyroid hormone-related protein and its receptors: nuclear functions and roles in the renal and cardiovascular systems, the placental trophoblasts and the pancreatic islets. Br J Pharmacol. 2001 Nov; 134(6): 1113-1136. doi: 10.1038/sj.bjp.0704378.

43. Clement P.B., Young R.H., Scully R.E. Clinical syndromes associated with tumors of the female genital tract. Semin Diagn Pathol. 1991; 8(4): 204-233.

44. Cramer S.D., Peehl D.M., Edgar M.G., Wong S.T., Deftos L.J., Feldman D. Parathyroid hormone-related protein (PTHrP) is an epidermal growth factor-regulated secretory product of human prostatic epithelial cells // Prostate. 1996; 29: 20-29.

45. Cros M., Silve C., Graulet A-M., Morieux C., Ureña P., de Vernejoul M-C., Bouizar Z. Estrogen Stimulates PTHrP But Not PTH/PTHrP Receptor Gene Expression in the Kidney of Ovariectomized Rat. Journal of Cellular Biochemistry.1998; 70(1): 84-93.

46. Czykier, E., Zabel, M., \& Surdyk-Zasada, J. (2001). Immunolocalization of PTHrP in the European bison and pine vole testis and epididymis. Folia histochemica et cytobiologica, 39 2, 57-61.

47. Daifotis A.G., Weir E.C., Dreyer B.E., Broadus AE., Stretch-induced parathyroid.

48. Daifotis A.G., Weir E.C., Dreyer B.E., Broadus AE., Stretch-induced parathyroidhormone-related peptide gene expression in the rat uterus. J Biol Chem. 1992; 25; 267(33): 23455-8. 
49. Danilin, S.; Sourbier, C.; Thomas, L.; Rothhut, S.; Lindner, V.; Helwig, J.J.; Jacqmin, D.; Lang, H.; Massfelder, T. von Hippel-Lindau tumor suppressor gene-dependent mRNA stabilization of the survival factor parathyroid hormone-related protein in human renal cell carcinoma by the RNA-binding protein HuR. Carcinogenesis 2009, 30, 387-396.

50. De Miguel, F., García-Cañero, R., and Esbrit, P. Copurification of calcium transport-stimulating and DNA synthesis-stimulating agents with parathormone-like activity isolated from the hypercalcemic strain of the Walker 256 tumor. Eur J Cancer. 1991; 27: 1022-1026.

51. Drake M.J., Hedlund P., Harvey I.J. et al. Partial outlet obstruction enhances modular autonomous activity in the isolated rat bladder. $\mathrm{J}$ Urol. 2003; 170(1): 276-279.

52. Ebeling P.R., Adam W.R., Moseley J.M., Martin T.J. Actions of synthetic parathyroid hormone-related protein (1-34) on the isolated rat kidney..J Endocrinol. 1989 Jan; 120 (1): 45-50.

53. Eddy, A.A. Interstitial nephritis induced by protein-overload proteinuria. Am J Pathol. 1989; 135: 719-733.

54. Eddy, A.A., Giachelli, C.M. Renal expression of genes that promote interstitial inflammation and fibrosis in rats with protein-overload proteinuria. Kidney Int. 1995; 47: 1546-1557.

55. Egido J. Vasoactive hormones and renal sclerosis. Kidney International, Vol. 49, № 2, (1996), pp. 578-597.

56. Emly J.F., Gregory J., Bowden S.J., Ahmed A., Whittle M.J., Rushton D.I., Ratcliffe W.A. Immunohistochemical localization of parathyroid hormone-related protein (PTHrP) in human term placenta and membranes. Placenta. 1994; 15(6): 653-660.

57. Endlich K., Massfelder T., Helwing J.J., Steinhausen M. Vascular effects of parathyroid hormone and parathyroid hormone-related protein in the split hydronephrotic rat kidney. J. Physiol.(Lond) 1995; $483: 481-490$.

58. Endlich N., R. Nobiling, W. Kriz, K. Endlich, Expression and signaling of parathyroid hormone-related protein in cultured podocytes, Experimental Nephrology, vol. 9, № 6, pp. 436-443, 2001.

59. Esbrit P., Rámila D., Ardura J.A., Ortega A., Romero M., Bosch R.J.: Role of PTHrP in renal pathophysiology. In: Novel Aspects of PTHrP 
Physiopathology, edited by Luparello C, editor. New York, Nova Science Publishers, 2007: 95-113.

60. Esbrit P., Egido J. The emerging role of parathyroid hormonerelated protein as a renal regulating factor. Nephrol. Dial. Transplant. 2000; 15 (8): 1109-1111.

61. Esbrit P., Santos S., Ortega A., Fernández-Agulló T., Vélez E., Troya S. et al. (2001) Parathyroid hormone-related protein as a renal regulating factor. From vessels to glomeruli and tubular epithelium. Am. J. Nephrol. 2001 21(3), 179-184.

62. Esteban, V., Lorenzo, O., Rupérez, M. et al. Angiotensin II, via AT1 and AT2 receptors and NF-kappaB pathway, regulates the inflammatory response in unilateral ureteral obstruction. J Am Soc Nephrol. 2004; 15: 1514-1529.

63. Fan, J.M., Ng, Y.Y., Hill, P.A., Nikolic-Paterson, D.J., Mu, W., Atkins, R.C., \& Lan, H.Y. Transforming growth factor-beta regulates tubular epithelial-myofibroblast transdifferentiation in vitro. Kidney International, Vol. 56, № 4, (1999), pp. 1455-1467.

64. Feng C.C., Ding G.X., Song N.H., Li X., Wu Z., Jiang H.W., Ding Q. Paraneoplastic hormones: parathyroid hormone-related protein (PTHrP) and erythropoietin (EPO) are related to vascular endothelial growth factor (VEGF) expression in clear cell renal cell carcinoma. Tumour Biol. 2013 Dec; 34(6): 3471-6. doi: 10.1007/s13277-013-0924-7.

65. Ferguson J.E., Gorman J.V., Bruns D.E., Weir E.C., Burtis W.J., Martin T.J. and Bruns M.E.: Abundant expression of parathyroid hormone-related protein in human amnion and its association with labor. Proc Natl Acad Sci USA.1992; 89: 8384-8388.

66. Fiaschi-Taesch N., Endlich N., Massfelder T., Endlich K., Stewart A.F., Helwig J.J. 1998 Renovascular parathyroid hormone-related protein in spontaneously hypertensive rats: dilator or trophic factor? Kidney Int. 1998; Suppl 67: S207-210.

67. Fiaschi-Taesch, N.M., Santos, S., Reddy, V., Van Why, S.K., Philbrick, W.F., Ortega, A., Esbrit, P., Orloff, J.J., \& Garcia-Ocaña, A. Prevention of acute ischemic renal failure by targeted delivery of growth factors to the proximal tubule in transgenic mice: the efficacy of parathyroid hormone-related protein and hepatocyte growth factor. Journal of the American Society of Nephrology, Vol. 15, № 1, (2004), pp. 112-125. 
68. Flanagan J.A., Power D.M., Bendell L.A., Guerreiro P.M., Fuentes J., Clark M.S., Canario A.V., Danks J.A., Brown B.L., Ingleton P.M. Cloning of the cDNA for sea bream (Sparus aurata) parathyroid hormone-related protein. Gen Comp Endocrinol.2000, 118: 373-382.

69. Fritsch S., Lindner V., Welsch S., Massfelder T., Grima M., Rothhut S., Barthelmebs M., Helwig J.J. Intravenous delivery of PTH/PTHrP type 1 receptor cDNA to rats decreases heart rate, blood pressure, renal tone, renin angiotensin system, and stress-induced cardiovascular responses. J Am Soc Nephrol 15: 2588-2600, 2004

70. Funk J.L., Moser A.H., Strewler G.J., Feingold K.R., Grunfeld C. Parathyroid hormone-related protein is induced during lethal endotoxemia and contributes to endotoxin-induced mortality in rodents. Mol. Med. 1996; 2: 204-210.

71. Funk, J.L. (2001). A role for parathyroid hormone-related protein in the pathogenesis of inflammatory/autoimmune diseases. International Immunopharmacology, Vol. 1, № 6, (2001), pp. 1101-1121.

72. Galbraith, S.C., Van Why, S., Zager, R., Siegel, N., and Orloff, J.J. Parathyroid hormone-related protein (PTHrP) expression is upregulated in renal proximal tubule cells in response to in vitro tubular injury. (abstract) J Bone Miner Res. 1996; 11: S411.

73. Garcia-Ocana A., Galbraith S.C., Van Why S.K., Yang K., Golovyan L., Dann P, Zager R.A., Stewart A.F., Siegel N.J., Orloff J.J.: Expression and role of parathyroid hormone-related protein in human renal proximal tubule cells during recovery from ATP depletion. J Am Soc Nephrol 10: 238-244, 1999.

74. García-Ocaña A., Gómez-Casero E., Peñaranda C., Esbrit P. Parathyroid hormone-related protein increases DNA synthesis in proximal tubule cells by cyclic AMP- and protein kinase C-dependent pathways. Life Sci. 1998; 62(25): 2267-73.

75. García-Ocaña, A., De Miguel, F., Peñaranda, C., Albar, J.P., Sarasa, J.L., Esbrit, P. Parathyroid hormone-related protein is an autocrine modulator of rabbit proximal tubule cell growth. J Bone Miner Res. 1995; 10(12): 1875-1884.

76. García-Ocaña, A., Gómez-Casero, E., Peñaranda, C., Sarasa, J.L., \& Esbrit, P. (1998). Cyclosporine increases renal parathyroid 
hormone-related protein expression in vivo in the rat. Transplantation, Vol. 65, № 6, (1998), pp. 860-863.

77. Gómez-Garre, D., Largo, R., Soto, K., Tejera, N., and Egido, J. Overload proteinuria elicits nuclear factor ;B activation in tubular epithelial cells: Role of angiotensin II and endothelin-1. (abstract) J Am Soc Nephrol. 1998; 9: 400A.

78. Gómez-Garré, D., Largo, R., Tejera, N. et al. Activation of NFkappaB in tubular epithelial cells of rats with intense proteinuria: role of angiotensin II and endothelin-1. Hypertension. 2001; 37: 1171-1178.

79. Gore-Hyer, E., Shegogue, D., Markiewicz, M., Lo, S., Hazen-Martin, D., Greene, E.L., Grotendorst, G., \& Trojanowska, M. (2002). TGFbeta and CTGF have overlapping and distinct fibrogenic effects on human renal cells. American Journal of Physiology. Renal Physiology, Vol. 283, №4, (October 2002), pp. F707-F716.

80. Gotoh A., Kitazawa S., Mizuno Y. et al. Common expression of parathyroid hormone-related protein and no correlation of calcium level in renal cell carcinomas // Cancer. - 1993. - 71. - P. 2803-6.

81. Grände, M., Frazen, A., Karlsson, J.O., Ericson, L.E., Heldin N.E., \& Nilsson, M. Transforming growth factor-beta and epidermal growth factor synergistically stimulate epithelial to mesenchymal transition (EMT) through a MEK-dependent mechanism in primary cultured pig thyrocytes. Journal of Cell Science, Vol. 115, № Pt 22, (r 2002), pp. 4227-4236.

82. Grob F., Zambrano P., Ibarra X., Reyes M.L. Parathyroid hormone-independent hypercalcemia in an infant with renal dysplasia: possible role of PTHrP. J Pediatr Endocrinol Metab. 2013; 26(3-4): 365-7.

83. Gross M.L., Ritz E., Schoof A. et al., Comparison of renal morphology in the Streptozotocin and the SHR/N-cp models of diabetes, Laboratory Investigation, vol. 84, № 4, pp. 452-464, 2004.

84. Guenther, H.L., Hofstetter, W., Moseley, J.M., Gillespie, M.T., Suda, N., and Martin, T.J. Evidence for the synthesis of parathyroid hormone-related protein (PTHrP) by nontransformed clonal rat osteoblastic cells in vitro. Bone. 1995; 16: 341-347.

85. Guijarro C., Egido J. Transcription factor-kappa B (NF-kappa B) and renal disease. Kidney Int. 2001; 59: 415-424. 
86. Guillén C., Martínez, P., de Gortázar, A.R., Martínez, M.E., \& Esbrit, P. (2002). Both N- and C-terminal domains of parathyroid hormonerelated protein increase interleukin-6 by nuclear factor-kappa B activation in osteoblastic cells. Journal of Biological Chemistry, Vol. 277, № 31, (2002), pp. 28109-28117.

87. Guo Y., Zhang A., Ding Y., Wang Y., Yuan W. Genistein ameliorates parathyroid hormone-induced epithelial-to-mesenchymal transition and inhibits expression of connective tissue growth factor in human renal proximal tubular cells. Archives of Medical Science. 2013; 9(4): 724-730. doi:10.5114/aoms.2013.36929.

88. Hanada M., Feng.J, Hemmings BA.Structure, regulationandfunc-tionofPKB/AKT-amajortherapeutictarget. Biochim Biophys Acta. 2004; 1697: 3-16.

89. Harris, R.C., Martínez-Maldonado, M. (1995). Angiotensin IImediated renal injury. Mineral and Electrolyte Metabolism, Vol. 21, № 4-5, (1995), pp. 328-335.

90. Hashitani H., Brading A.F., Suzuki H. Correlation between spontaneous electrical.

91. Hashitani H., Brading A.F., Suzuki H. Correlation between spontaneous electrical, calcium and mechanical activity in detrusor smooth muscle of the guinea-pig bladder. Br J. Pharmacol. 2004; 141(1): 183-93.

92. Henderson, J.E., Amizuka, N., Warshawsky, H., Biasotto, D., Lanske, B.M., Goltzman, D., Karaplis, A.C. (1995). Nucleolar localization of parathyroid hormone-related peptide enhances survival of hondrocytes under conditions that promote apoptotic cell death. Molecular and Cell Biology, Vol. 15, № 8, (1995), pp. 4064-4075.

93. Hengst L., Reed S.I., Inhibitors of the Cip/Kip family, Current Topics in Microbiology and Immunology, vol. 227, pp. 25-41, 1997.

94. Hirasawa K., Kitamura T., Oka T., Matsushita H. Bladder tumor producing granulocyte colony-stimulating factor and parathyroid hormone related protein. J Urol 2002, 167: 2130. doi: 10.1016/S00225347(05)65104-X.

95. Hochane M., Raison D., Coquard C., Béraud C., Bethry A., Danilin S., Massfelder T., Barthelmebs M. Parathyroid hormone-related protein modulates inflammation in mouse mesangial cells and blunts 
apoptosis by enhancing COX-2 expression. Am J Physiol Cell Physiol. 2018.1; 314(2): C242-C253. doi: 10.1152/ajpcell.00018.2017.

96. Hochane M., Raison D., Coquard C., Béraud C., Danilin S., Bethry A., Massfelder T., Barthelmebs M.P. Parathyroid Hormone-Related Protein Contributes to Early Healing of Habu Snake Venom-Induced Glomerulonephritis in Mice. Am J Pathol. 2018; 188(4): 863-875. doi: 10.1016/j.ajpath.2017.12.012.

97. Hochane M., Raison D., Coquard C., Imhoff O., Massfelder T., Moulin B. et al. (2013) Parathyroid hormone-related protein is a mitogenic and a survival factor of mesangial cells from male mice: role of intracrine and paracrine pathways. Endocrinology 154, 853-864.

98. Höfle G., Gasser R.W., Buchfelder M., Fahlbusch R., Waldenberger P., Finkenstedt G. Elevated inferior petrosal sinus levels of PTHrP was reported in a patient with Cushing's disease. Clin Endocrinol (Oxf) 2001; 54: 555-7.

99. Holt E.H., Lu C., Dreyer B.E., Dannies P.S., Broadus A.E.: Regulation of parathyroid hormone-related peptide gene expression by estrogen in $\mathrm{GH} 4 \mathrm{C} 1$ rat pituitary cells has the pattern of a primary response gene. J Neurochem 62: 1239-1246, 1994.

100. Hongo, T., Kuofer, J., Enomoto, H., Sharifi, B., Giannella-Neto, D., Forester, J., Singer, F.R., Goltzman, D., Hendy, G.N., Pirola, C., Fagin, J.A., and Clemens, T.L. Abundant expression of parathyroid hormone-related protein in primary rat aortic smooth muscle cells accompanies serum-induced proliferation. J Clin Invest. 1991; 88: 1841-1847.

101. Horiuchi N., Caulfield M.P., Fisher J.E. et al. Similarity of synthetic peptide from human tumor to parathyroid hormone in vivo and in vitro. Science 1987; 238: 1566-1568.

102. Hoshi S., Numahata K., Morozumi K., Katumata Y., Kuromoto A., Takai Y., Hoshi K., Bilim V., Sasagawa I. Bladder cancer metastasis producing beta-human chorionic gonadotropin, squamous cell carcinoma antigen, granulocyte-colony stimulating factor, and parathyroid hormone-related protein, IJU Case Reports. 2018; 2(1): 47-50.

103. Hu C., Sun L., Xiao L., Han Y., Fu X., Xiong X. et al. (2015) Insights into the mechanisms involved in the expression and regulation of extracellular matrix proteins in diabetic nephropathy. Curr. Med. Chem.22, 2858-2870. 
104. Huang, H.C., Preisig P.A. (2000). G1 kinases and transforming growth factor-beta signaling are associated with a growth pattern switch in diabetes-induced renal growth. Kidney International, Vol. 58, № 1, (2000), pp. 162-172.

105. Humes H.D., Cieslinski D.A., Coimbra T.M., Messana .M., Galvao C.: Epidermal growth factor enhances renal tubule cell regeneration and repair and accelerates the recovery of renal function in postischemic acute renal failure. J Clin Invest 84: 1757-1761, 1989.

106. Humes, H.D., Lake, E.W., \& Liu, S. (1995). Renal tubule cell repair following acute renal injury. Mineral and Electrolyte Metabolism, Vol. 21, № 4-5, (1995), pp. 353-365.

107. Hwang J.I., Moon M.J., Park S., et al. Expansion of secretin-like $G$ protein-coupled receptors and their peptide ligands via local duplications before and after two rounds of whole-genome duplication. Mol Biol Evol. 2013; 30: 1119-30.

108. Ichikawa, I. and Harris, R.C. Angiotensin actions in the kidney: Renewed insight into the old hormone. Kidney Int. 1991; 40: 583-596.

109. Ikeda Y., Fry C., Hayashi F., et al. Role of gap junctions in spontaneous activity of the rat bladder. Am J Physiol Renal Physiol. 2007; 293(4): F1018-25.

110. Imamura M., Kanematsu A., Yamamoto S., et al. Basic fibroblast growth factor modulates proliferation and collagen expression in urinary bladder smooth muscle cells. Am. J Physiol Renal Physiol. 2007; 293(4): F1007-F1017.

111. Imamura M., Negoro H., Kanematsu A., et al. Basic fibroblast growth factor causes urinary bladder overactivity through gap junction generation in the smooth muscle. Am J Physiol Renal Physiol. 2009; 297(1): F46-54.

112. Ingleton P.M. Parathyroid hormone-related protein in lower vertebrates. Comparative Biochemistry and Physiology. Part B, Biochemistry \& Molecular Biology. 2002, 132(1): 87-95.

113. Ito Y., Aten J., Bende R.J., et al. Expression of connective tissue growth factor in human renal fibrosis. Kidney Int 1998; 53: 853-61.

114. Iwamura M., Wu G., Abrahamsson P.A. et al. Parathyroid hormone-related protein is expressed by prostatic neuroendocrine cells. Urology. 1994b; 43: 667-674. 
115. Iwamura M., Wu W., Muramoto M. et al. Parathyroid hormonerelated protein is an independent prognostic factor for renal cell carcinoma // Cancer. - 1999; 86(6): 1028-34.

116. Iwano M., Plieth D., Danoff T.M., et al. Evidence that fibroblasts derive from epithelium during tissue fibrosis. J Clin Invest 2002; 110: 341-50

117. Izquierdo A., López-Luna, P., Ortega, A., Romero, M., GutiérrezTarrés, M.A., Arribas, I., Esbrit P., Bosch, R.J. (2006). The parathyroid hormone-related protein system and diabetic nephropathy outcome in streptozotocin-induced diabetes. Kidney International, Vol. 69, № 12, (2006), pp. 2171-2178.

118. Jiang, B.B., Morimoto, S., Fukuo, S., Hirotani, A., Tamatani, M., Nakahashi, T., Nishibe, A., Niinobu, T., Hata, S., Chen, S.Y., and Ogihara, T. Parathyroid hormone-related protein inhibits endothelin-1 production. Hypertension. 1996; 27: 360-363.

119. Jobert, A.S., Fernandes, I., Turner, G., Coureau, C., Prie, D., Nissenson, R.A., Friedlander, G., Silve, C. (1996). Expression of alternatively spliced isoforms of the parathyroid hormone (PTH)/PTH-related peptide receptor messenger RNA in human kidney and bone cells. Molecular Endocrinology, Vol. 10, № 9, (1996), pp. 1066-1076.

120. Jones E.A., Shahed A., Shoskes D.A.: Modulation of apoptotic and inflammatory genes by bioflavonoids and angiotensin II inhibition in ureteral obstruction. Urology 56: 346-351, 2000.

121. Joun H., Lanske B., Karperien M., Qian F., Defize L., Abou-Samra A. Tissue-specific transcription start sites and alternative splicing of the parathyroid hormone (PTH)/PTH-related peptide (PTHrP) receptor gene: a new $\mathrm{PTH} / \mathrm{PTHr} \mathrm{P}$ receptor splice variant that lacks the signal peptide.Endocrinology. 1997; 138:1742-1749.

122. Kadin M.E., Cavaille-Coll M.W., Gertz R., J. Massagué, S. Cheifetz, D. George, Loss of receptors for transforming growth factor $\beta$ in human T-cell malignancies, Proceedings of the National Academy of Sciences of the United States of America, vol. 91, № 13, pp. 6002-6006, 1994.

123. Kalluri, R., Neilson E.G. (2003). Epithelial-mesenchymal transition and its implications for fibrosis. Journal of Clinical Investigation, Vol. 112, № 12, (December 2003), pp. 1776-1784. 
124. Kamai T., Arai G., Takagi K., Kamai T., Arai G., Takagi K.: Granulocyte colony-stimulating factor and parathyroid hormone related protein producing bladder cancer. J Urol. 1999, 161: 1565-1566. 10.1097/00005392-199905000-00044.

125. Kashihara N., Sugiyama H., Makino H. Mechanisms for induction ofapoptosis and glomerular disease. NephrolDialTransplant.1999; 14 Suppl 1:52-54.

126. Kato T., Yasuda K., Iida H., Watanabe A., Fujiuchi Y., Miwa S., Imura J., Komiya A. Trousseau's syndrome caused by bladder cancer producing granulocyte colony-stimulating factor and parathyroid hormonerelated protein: A case report. Oncol Lett. 2016 Nov; 12(5): 4214-4218. doi: 10.3892/ol.2016.5152.

127. Katsumata S.-I., Masuyama R., Uehara M., Suzuki K. 2004. Decreased mRNA expression of the PTH/PTHrP receptor and type II sodium-dependent phosphate transporter in the kidney of rats fed a high phosphorus diet accompanied with a decrease in serum calcium concentration. Biosci. Biotech. Biochem. 68: 2484- 2489.

128. Kaushal, G.P., Basnakian, A.G., \& Shah, S.V. (2004). Apoptotic pathways in ischemic acute renal failure. Kidney International, Vol. 66, № 2, (2004), pp. 500-506.

129. Kawane T., Saikatsu S., Akeno N., Abe M., Horiuchi N.. 1997. Starvation-induced increase in the parathyroid hormone/ PTH related protein receptor mRNA of bone and kidney in shamoperated and thyroparathyroidectomized rats. Eur. J. Endocrinol. 137: $273-280$.

130. Kitazawa S., Kitazawa R., Fukase M. et al. Immunohistochemical evaluationof parathyroid hormone-related protein (PTHrP) in the uterine cervix. Int. J Cancer. 1992; 50: 731-735.

131. Kodous N., Filler G., Sharma A.P., Van Hooren T.A. PTHrP-related Hypercalcaemia in Infancy and Congenital Anomalies of the Kidney and Urinary Tract (CAKUT). Canadian journal of kidney health and disease (2015).2:21 DOI 10.1186/s40697-015-0052-y.

132. Kolm V., Sauer U., Olgemooller B. and Schleicher E.D. (1996) High glucose-induced TGF- $\beta 1$ regulates mesangial production of heparan sulfate proteoglycan. Am. J. Physiol. 270, F812-F821. 
133. Kontogiannis, J., \& Burns, K.D. (1998). Role of AT1 angiotensin II receptors in renal ischemic injury. American Journal of Physiology. Renal Physiology, Vol. 274, № 1-Pt2, (1998), pp. F79-F90.

134. Kramann R., Schneider R.K. Parathyroid hormone-related protein and regulation of cell survival in the kidney. Kidney international. 2013; 83(5): 777-779.

135. Kriz, W., Grezt, N., \& Lemley, K.V. (1998). Progression of glomerular diseases: is the podocyte the culprit?. Kidney International, Vol. 54, № 3, (1998), pp. 687-697.

136. Kuwahara, M., Inoshita, S., Nakano, Y., Terada, Y., Takano, Y., and Sasaki, S. 2007. Expression of bone type $1 \mathrm{PTH}$ receptor in rats with chronic renal failure. Clin. Exp. Nephrol. 11: 34- 40.

137. Lang H., Endlich N., Lindner V., Endlich K., Massfelder T., Stewart A.F., Saussine C., Helwig J.J. Parathyroid hormone-related protein in rat penis: expression, localization, and effect on cavernosal pressure. Endocrinology. 1999 Sep; 140(9):4342-50.

138. Largo R., Gómez-Garre D., Santos S., Carlos Peñaranda, Blanco J., Esbrit P. et al. Renal expression of parathyroid hormone-related protein (PTHrP) and PTH/PTHrP receptor in a rat model of tubulointerstitial damage. Kidney International, 1999; Volume 55, Issue 1, 82-90.

139. Largo, R., Gómez-Garre, D., Soto, K., Marrón, B., and Egido, J. Angiotensin converting enzyme (ACE) is up-regulated in the proximal tubules of rats with protein-overload proteinuria. (abstract) J Am Soc Nephrol. 1997; 8: 501.

140. Law F., Bonjour J.P., Rizzoli R.: Transforming growth factor-beta: a down-regulator of the parathyroid hormone-related protein receptor in renal epithelial cells. Endocrinology 134: 2037-2043, 1994.

141. Law F., Rizzoli R., Bonjour J.P.: Transforming growth factor-beta modulates the parathyroid hormone-related protein-induced responses in renal epithelial cells. Endocrinology 133: 145-151, 1993.

142. Lee K., Mitsui R., Kajioka S. et al. Role of PTHrP and sensory nerve peptides in regulating the contractility of muscularis mucosae and detrusor smooth muscle in the guinea-pig bladder. The Journal of Urology. 2016; 196(4): 1287-1294. DOI: 10.1016/j.juro.2016.04.082.

143. Lee, F.T., Cao, Z., Long, D.M. et al. Interactions between angiotensin II and NF-kappaB-dependent pathways in modulating 
macrophage infiltration in experimental diabetic nephropathy. J Am Soc Nephrol. 2004; 15: 2139-2151.

144. Lee, K., Brown, D., Ureña, P., Ardaillou, N., Ardaillou, R., Deeds, J., and Segre, G.V. Localization of parathyroid hormone/parathyroid hormone-related peptide receptor mRNA in kidney. Am J Physiol. 1996; 270: F186-F191.

145. Lewis M.P., Norman J.T. Differential response of activated versus nonactivated renal fibroblasts to tubular epithelial cells: a model of initiation and progression of fibrosis? Exp Nephrol 6: 132-143, 1998.

146. Lieberthal, W., Levine, J.S. (1996). Mechanisms of apoptosis and its potential role in renal tubular epithelial cell injury. American Journal of Physiology. Renal Physiology Vol. 271, № 3 Pt2 (September 1996), pp. F477-F488.

147. Liu L., Qiu W., Wang H., et al. Sublytic C5b-9 complexes induceapoptosis of glomerular mesangial cells in rats with Thy-1 nephritisthrough role of interferon regulatory factor-1-dependent caspase 8activation. J Biol Chem. 2012; 287: 16410-16423.

148. Liu Y. Epithelial to mesenchymal transition in renal fibrogenesis: pathologic significance, molecular mechanism, and therapeutic intervention. Journal of the American Society of Nephrology. 2004; 15(1): 1-12.

149. Long, G.W., Misra, D.C., Juleff, R., Blossom, G., Czako, P.F., \& Glover, J.L. (1993). Protective effects of enalaprilat against postischemic renal failure. Journal of Surgical Research, Vol. 54, № 3, (1993), pp. 254-257.

150. López-Hernández F.J. and López-Novoa J.M. (2012) Role of TGF- $\beta$ in chronic kidney disease: an integration of tubular, glomerular and vascular effects. Cell Tissue Res. 347, 141-154.

151. Lorenzo O., Ruiz-Ortega, M., Esbrit, P., Rupérez, M., Ortega, A., Santos, S., Blanco, J., Ortega, L., \& Egido, J. Angiotensin II increases parathyroid hormone-related protein (PTHrP) and the type $1 \mathrm{PTH} / \mathrm{PTHrP}$ receptor in the kidney. Journal of the American Society of Nephrology.2002; 13(6): 1595-1607.

152. Luparello C. Regulator of Life/Death Decisions by Tumor Cells with Potential Clinical Applications. Cancers. 2011; 3(1): 396-407; doi:10.3390/cancers3010396.

153. MacIsaac, R.J., Horne, R.S.C., Caple, I.W., Martin, T.J., \& Wintour, E.M. (1993). Effects of thyroparathyroidectomy, parathyroid 
hormone, and PTHrP on kidneys of ovine fetuses. American Journal of Physiology - Endocrinology and Metabolism, 1993; 264(1): 37-44.

154. Maeda S., Sutliff R.l., Qian J., Lorenz J.N., Wang J., Tang H., Nakayama T., Weber C., Witte D., Strauch A.R., Paul R.J., Fagin J.A., Clemens T.L. Targeted overexpression of parathyroid hormone-related protein (PTHrP) to vascular smooth muscle in transgenic mice lowers blood pressure and alters vascular contractility. Endocrinology. 1999; $140: 1815-1825$.

155. Maeda Y., Nakazawa H., Yoshimura N., Okuda H., Oshima T., Ito F., Onitsuka S., Kihara T., Goya N., Toma H.: Bladder carcinoma presenting with hypercalcemia: a case report. Hinyokika Kiyo. 1997; 43: 137-140.

156. Manning B.D., Cantley L.C. AKT/PKBsignaling: navigatingdown-stream. Cell. 2007; 129: 1261-1274.

157. Marcinkowski, W., Zhang, G., Smogorzewski, M., and Massry, S.G. Elevation of $[\mathrm{Ca2+}$ of renal proximal tubular cells and downregulation of mRNA of PTH-PTHrP, V1a and AT1 receptors in kidney of diabetic rats. Kidney Int. 1997; 51: 1950-1955.

158. Martínez-Estrada, O.M., Cullerés, A., Soriano, F.X., Peinado, H., Bolós, V., Martínez, F.O., Reina, M., Cano, A., Fabre, M., \& Vilaró, S. (2006). The transcription factors Slug and Snail act as repressors of Claudin-1 expression in epithelial cells. Biochemical Journal, Vol. 394, № Pt2 (March 2006), pp. 449-457.

159. Martín-Ventura, J.L., Ortego, M., Esbrit, P., Hernández-Presa, M.A., Ortega, L., Egido, J. (2003). Possible role of parathyroid hormone-related protein as a proinflammatory cytokine in atherosclerosis. Stroke, Vol. 34, № 7, (2003), pp. 1783-1789.

160. Massfelder T, Taesch N., Fritsch S., Eichinger A., Barthelmebs M., Stewart A.F., Helwig J.J. Type 1 parathyroid hormone receptor expression level modulates renal tone and plasma renin activity in spontaneously hypertensive rat. J Am Soc Nephrol 13: 639-648, 2002.

161. Massfelder T., Parekh N., Endlich K., Saussine C., Steinhausen M. and Helwig J.J. (1996) Effect of intrarenally infused parathyroid hormone-related protein on renal blood flow and glomerular filtration rate in the anaesthetized rat. Br. J. Pharmacol. 1996a; 118, 1995-2000. 
162. Massfelder T., Taesch N., Endlich N., Eichinger A., Escande B., Endlich K., Barthelmebs M., Helwig J.J. Paradoxical actions of exogenous and endogenous parathyroid hormone-related protein on renal vascular smooth muscle cell proliferation: reversion in the SHR model of genetic hypertension. FASEB J. 2001; 15:707-718.

163. Massfelder T.; Lang, H.; Schordan, E.; Lindner, V.; Rothhut, S.; Welsch, S.; Simon-Assmann, P.; Barthelmebs, M.; Jacqmin, D.; Helwig, J.J. Parathyroid hormone-related protein is an essential growth factor for human clear cell renal carcinoma and a target for the von HippelLindau tumor suppressor gene. Cancer Res. 2004, 64, 180-188.

164. Massfelder, T., Saussine, C., Simeoni, U., Enanga, B., Judes, C., and Helwig, J.J. Evidence for adenylyl cyclase-dependent receptors for parathyroid hormone (PTH)-related protein in rabbit kidney glomeruli. Life Sci. 1993; 53: 875-881.

165. Massfelder, T., Stewart, A.F., Endlich, K., Soifer, N., Judes, C., and Helwig, J.J. Parathyroid hormone-related protein detection and interaction with $\mathrm{NO}$ and cyclic AMP in the renovascular system. Kidney Int. 1996b; 50: 1591-1603.

166. Matsumoto K., Nakamura T. (2001). Hepatocyte growth factor: renotropic role and potential therapeutics for renal diseases. Kidney Internacional, Vol. 59, № 6, (2001), pp. 2023-2038, ISSN 0085-2538.

167. Matsuoka S., Miura Y., Kachi T., et al. Humoral hypercalcemia of malignancyassociated with parathyroid hormone-related protein producing transitional cellcarcinoma of the ureter. Intern Med 1994; 33: 107-9.

168. McCarthy C.J., Zabbarova I.V., Brumovsky P.R. et al. Spontaneous contractionsevoke afferent nerve firing in mouse bladders with detrusor overactivity. J Urol. 2009; 181(3): 1459-66.

169. McCuaig K.A., Lee H.S., Clarke J.C., Assar H., Horsford J., White J.H. Parathyroid hormone/parathyroid hormone related peptide receptor gene transcripts are expressed from tissue-specific and ubiquitous promoters. Nucleic Acids Res. 1995 23(11): 1948-55.

170. McKay N.G., Khong T.F., Haites N.E. and Power D.A. (1993) The effect of transforming growth factor beta 1 on mesangial cell fibronectin synthesis: increased incorporation into the extracellular matrix and reduced pI but no effect on alternative splicing. Exp. Mol. Pathol. 59, 211-224. 
171. McRae S.N., Gilbert R., Deamant F.D., Reese J.H.: Poorly differentiated carcinoma of bladder producing granulocyte colony-stimulating factor and parathyroid hormone related protein. J Urol. 2001, 165: 527528. 10.1097/00005392-200102000-00049.

172. Meng E., Young J.S., Brading A.F. Spontaneous activity of mouse detrusor smoothmuscle and the effects of the urothelium. Neurourol Urodyn. 2008; 27(1): 79-87.

173. Merryman, J.I., Deville, J.W., Werkmeister, J.R., Capen, C.C., and Rosol, T.J. Effects of transforming growth factor-beta on parathyroid hormone-related protein production and ribonucleic acid expression by a squamous carcinoma cell line in vitro. Endocrinology. 1994; 134: 2424-2430.

174. Mezzano S.A., Ruiz-Ortega M., Egido J. Angiotensin II and renal fibrosis. Hypertension 2001; 38 (3 Pt 2): 635-638.

175. Mifsud, S.A., Allen, T.J., Bertram, J.F., Hulthen, U.L., Kelly, D.J., Cooper, M.E., WilkinsonBerka, J.L., Gilbert, R.E. (2001). Podocyte foot process broadening in experimental diabetic nephropathy: amelioration with renin-angiotensin blockade. Diabetologia, Vol. 44, №4, (July 2001), pp. 878-882.

176. Miller S.B., Martin D.R., Kissane J., Hammerman M.R.: Hepatocyte growth factor accelerates recovery from acute ischemic renal injury in rats.Am J Physiol.1994; 266: F129-F134.

177. Miller S.B., Martin D.R., Kissane J., Hammerman M.R.: IGF-I accelerates recovery from ischemic acute tubular necrosis in the rat. Proc Natl Acad Sci USA. 1992; 89: 11876-11880.

178. Morrissey J.J., Klahr S. Enalapril decreases nuclear factor kappa B activation in the kidney with ureteral obstruction. Kidney Int. 1997; 52: 926-933.

179. Moseley J.M., Kubota M., Diefenbach-Jagger H. et al. Parathyroid hormone-related protein purified from a human lung cancer cell line. PNAS 1987; 84: 5048-5052.

180. Moseley J.M., Hayman J.A., Danks J.A., Alcorn D., Grill V., Southby J., Horton M.A. Immunohistochemical detection of parathyroid hormone-related protein in human fetal epithelia. J. Clin.Endocrinol. Metab. 1991; 73: 478-484.

181. Muff R., Fischer J.A. Parathyroid hormone receptors in control of proximal tubule function. AnnuRev Physiol, 1992; 54: 67-79. 
182. Muller, G.A., Markovic-Lipkovski, J., Frank, J., \& Rodemann, H.P. The role of interstitial cells in the progression of renal diseases. Journal of the American Society of Nephrology.1992; 2 (10): S198-S205.

183. Murer H., Hernando N., Forster I. et al. Regulation of $\mathrm{Na} / \mathrm{Pi}$ transporter in the proximal tubule. Annu Rev Physiol 2003; 65: 531-542.

184. Musso, M.J., Barthelmebs, M., Imbs, J.L., Plante, M., Bollack, C., Helwig, J.J. (1989a). The vasodilator action of parathyroid hormone fragments on isolated perfused rat kidney. Naunyn-Schmiedeberg's Arch. Pharmacol. 1989a; 340: 246-251.

185. Musso, M.J., Plante, M., Judes, C., Barthelmebs, M., Helwig, J.J. Renal vasodilation and microvessel adenylate cyclase stimulation by synthetic parathyroid hormone-like protein fragments. Eur. J. Pharmacol. 1989b; 174: 139-151.

186. Nagataki S., Nakashima M., Akino K., et al. Parathyroid hormone-related peptide expression in endocrine tumors. Miner Electrolyte Metab 1995; 21: 148-51.

187. Nangaku M. Mechanisms of tubulointerstitial injury in the kidney: final common pathways to end-stage renal failure. Intern Med. 2004; 43: 9-17.

188. Nickols G.A., Nickols M.A., Helwig J.J. Binding of parathyroid hormone and parathyroid hormone-related protein to vascular smooth muscle of rabbit renal microvessels. Endocrinology. 1990; 126: 721-727.

189. Nishikawa N., Kanematsu A., Negoro H. et al. PTHrP Is Endogenous Relaxant forSpontaneous Smooth Muscle Contraction in Urinary Bladder of Female Rat. Endocrinology. 2013; 154 (6): 2058-2068.

190. Nishikawa N., Yago R., Yamazaki Y. et al. Expression of parathyroid hormone/parathyroid hormone-related peptide receptor 1 in normal and diseased bladder detrusor muscles:a clinico-pathological study. BMC Urol. 2015; 15(1): 2. DOI: 10.1186/1471-2490-15-2.191. Nishikawa Y., Wang M., Carr B.I. Changes in TGF-beta receptors of rat hepatocytes during primary culture and liver regeneration: increased expression of TGFbeta receptors associated with increased sensitivity to TGF-beta-mediated growth inhibition // Journal of Cellular Physiology. 1998; 176: 612-623.

192. Noda, M., Katoh, T., Takuwa, N., Kumada, M., Kurokawa, K., \& Takuwa, Y. (1994). Synergistic stimulation of parathyroid hormone-related 
peptide gene expression by mechanical stretch and angiotensin II in rat aortic smooth muscle cells. Journal of Biological Chemistry.1994; 269 (27): 17911-17917.

193. Noonan W.T., Qian J., Stuart W.D., Clemens T.L., Lorenz J.N. Altered renal hemodynamics in mice overexpressing the parathyroid hormone (PTH)/PTH-related peptide type 1 receptor in smooth muscle. Endocrinology.2003; 144: 4931-4938.

194. Okada H., Dannof T.M., Kalluri R., Neilson E.G. Early role of Fsp1 in epithelial-mesenchymal transformation. Am J Physiol Renal Physiol.1997; 273: F563-F574.

195. Okano K., Wu S., Huang X., Pirola C.J., Juppner H., Abou-Samra A.B., Segre G.V., Iwasaki K., Fagin J.A., Clemens T.L. Parathyroid hormone (PTH)/PTH-related protein (PTHrP) receptor and its messenger ribonucleic acid in rat aortic vascular smooth muscle cells and UMR osteoblast-like cells: cell-specific regulation by angiotensin-II and PTHrP. Endocrinology. 1994; 135: 1093-1099.

196. Okutsu H., Matsumoto S., Ohtake A. et al. Effect of tamsulosin on bladder bloodflow and bladder function in a rat model of bladder over distention/emptying induced bladder overactivity. J Urol. 2011; 186(6): 2470-7.

197. Ophascharoensuk V., Giachelli C.M., Gordon K. et al. Obstructive uropathy in the mouse: role of osteopontin in interstitial fibrosis and apoptosis. Kidney Int. 1999; 56: 571-580.

198. Orisio, S., Benigni, A., Bruzzi, I., Corna, D., Perico, N., Zoja, C., Benatti, L., and Remuzzi, G. Renal endothelin gene expression is increased in remnant kidney and correlates with disease progression.Kidney Int. 1993; 43: 354-358.

199. Ortega A., Romero M., Izquierdo A. Nuria Troyano Yolanda Arce Juan Antonio Ardura María Isabel Arenas Jordi Bover Pedro Esbrit Ricardo J. Bosch. Parathyroid hormone-related protein is a hypertrophy factor for human mesangial cells: Implications for diabetic nephropathy. J. Cell. Physiol.2012; 227: 1980-1987. https://doi.org/10.1002/jcp.22926.

200. Ortega, A., Rámila, D., Ardura, J.A., Esteban, V., Ruiz-Ortega, M., Barat, A., Gazapo, R., Bosch, R.J., \& Esbrit, P. Role of parathyroid hormone-related protein in tubulointerstitial apoptosis and fibrosis after 
folic acid-induced nephrotoxicity. Journal of the American Society of Nephrology, Vol. 17, №6, (2006), pp. 1594-1603.

201. Ortega, A., Rámila, D., Izquierdo, A., González, L., Barat, A., Gazapo, R., Bosch, R.J., Esbrit, P. Role of the renin-angiotensin system on the parathyroid hormonerelated protein overexpression induced by nephrotoxic acute renal failure in the rat. Journal of the American Society of Nephrology.2005; 16 (4): 939-949.

202. Ortiz, A., Lorz, C., Catalán, M.P., Danoff, T.M., Yamasaki, Y., Egido, J., Neilson, E.G. Expression of apoptosis regulatory proteins in tubular epithelium stressed in culture or following acute renal failure. Kidney International, Vol. 57, № 3, (2000), pp. 969-981.

203. Osterby R., Tapia J., Nyberg G., Tencer J., Willner J., Rippe B., Torffvit O. Renal structures in type 2 diabetic patients with elevated albumin excretion rate. Acta Pathologica Microbiologica et Immunologica Scandinavica.2001; 109 (11): 751-761.

204. Ott U. Aschoff A. Pocock J. et al. DNA fragmentation in chronic glomerulonephritis: an immunohistological analysis. NephronClinPract. 2007; 105: c18-28.

205. Ozkan B., Demirkesen O., Durak H. et al. Which factors predict upper urinary tract deterioration in overactive neurogenic bladder dysfunction? Urology, 2005; 66(1): 99-104. DOI.org/10.1016/j. urology.2005.02.009.

206. Pagtalunan, M.E., Miller, P.L., Jumping-Eagle, S., Nelson, R.G., Myers, B.D., Renke, H.G., Coplon, N.S., Sun, L., \& Meyer, T.W. (1997). Podocyte loss and progressive glomerular injury in type II diabetes. Journal of Clinical Investigation, Vol. 99, № 2, (January 1997), pp. 342-348.

207. Pantsulaia T. Role of TGF-beta in pathogenesis of diabetic nephropathy. Georgian Medical News.2006; 131(2): 13-18.

208. Perez-Martinez F.C., Juan Y.S., Lin W.Y. et al. Expression of parathyroid hormonerelated protein in the partially obstructed and reversed rabbit bladder. Int Urol Nephrol.2009; 41(3): 505-11.

209. Philbrick W.M., Wysolmerski J.J., Galbraith S., Holt E., Orloff J.J., Yang K.H., Vasavada R.C., Weir E.C., Broadus A.E., Stewart A.F. Defining the roles of parathyroid hormone-related protein in normal physiology. Physiol Rev. 1996; 76: 127-173. 
210. Pirola, C.J., Wang, H-M., Kamyar, A., Wu, S., Enomoto, H., Sharifi, B., Forrester, J.S., Clemens, T.L., Fagin, J.A. Angiotensin II regulates parathyroid hormone-related protein expression in cultured rat aortic smooth muscle cells through transcriptional and post-transcriptional mechanisms. J Biol Chem. 1993; 286: 1987-1994.

211. Poncelet A.C. and Schnaper H.W. (1998) Regulation of mesangial cell collagen turnover by transforming growth factor-beta1. Am. J. Physiol. 275, F458-F466.

212. Powers A.C., "Diabetes Mellitus," in Harrison's principles of Internal Medicine, D.L. Kasper, E. Braunwald, A.S. Fauci, S.L. Hauser, D.L. Longo, and J.L. Jamerson, Eds., pp. 2152-2180, McGRaw-Hill, New York, NY, USA, 16th edition, 2005.

213. Raison D., Coquard C., Hochane M., Jacques Steger, Thierry Massfelder, Bruno Moulin, Andrew C. Karaplis, Daniel Metzger, Pierre Chambon, Jean-Jacques Helwig, and Mariette Barthelmebs. Knockdown of parathyroid hormone related protein in smooth muscle cells alters renal hemodynamics but not blood pressure. Am J Physiol Renal Physiol.2013; 305(3): F333-F342, 2013. https://doi.org/10.1152/ajprenal.00503.2012.

214. Rámila D., Ardura, J.A., Esteban, V., Ortega, A., OrtegaRuiz, M., Bosch, R.J, Esbrit, P. (2008). Parathyroid hormone-related protein promotes inflammation in the kidney with an obstructed ureter. Kidney International. 2008; 73(7): 835-847.

215. Rees A.J. The role of infiltrating leukocytes in progressive renal disease: implications for therapy. Nature Clinical Practice. Nephrology. 2006; 2(7): 348-349.

216. Remuzzi, G., Bertani, T. (1998). Pathophysiology of progressive nephropathies. The New England Journal of Medicine, Vol. 339, № 20, (November 1998), pp. 1448-1456.

217. Remuzzi, G., Ruggenenti, P., and Benigni, A. Understanding the nature of renal disease progression.Kidney Int. 1997; 51: 2-15.

218. Rink M., Budäus L., Schäfer H., Friedrich M.G., Schlomm T., Regier M., Graefen M., Salomon G.Parathyroid Hormone-Related Protein and Granulocyte Colony-Stimulating Factor Overexpression in Poorly Differentiated Bladder Cancer Correlated with Decreasing Vigilance. Current Urology. 2009; 3(1):53-56. DOI: 10.1159/000189683. 
219. Ritz E., Rychlik I., Locatelli F., Halimi S., End-stage renal failure in type 2 diabetes: a medical catastrophe of worldwide dimensions // American Journal of Kidney Diseases, vol. 34, № 5, pp. 795-808, 1999.

220. Roca-Cusachs A., DiPette D.J., Nickols G.A. Regional and systemic hemodynamic effects of parathyroid hormone-related protein: preservation of cardiac function and coronary and renal flow with reduced blood pressure. J Pharmacol Exp Ther 256: 110-118, 1991.

221. Romero M., Ortega A., Olea N., Arenas M.I., Izquierdo A., Bover J., Esbrit P., Bosch R.J. Novel Role of Parathyroid Hormone-Related Protein in the Pathophysiology of the Diabetic Kidney: Evidence from Experimental and Human Diabetic Nephropathy. Journal of Diabetes Research. Volume 2013, Article ID 162846, 6 pages. http://dx.doi.org/10.1155/2013/162846.

222. Romero, M., Ortega, A., Izquierdo, A., López-Luna, P., \& Bosch, R.J. (2010). Parathyroid hormone-related protein induces hypertrophy in podocytes via TGF-beta (1) and p27 (Kip1): implications for diabetic nephropathy. Nephrology, Dialysis, Transplantation. 2010; Vol. 25, № 8, pp. 2447-2457.

223. Ruiz-Ortega, M., Egido, J. (1997). Angiotensin II modulates cell growth-related events and synthesis of matrix proteins in renal interstitial fibroblasts. Kidney International, Vol. 52, №6, (1997), pp. 1497-1510.

224. Ryan M.J., Johnson G., Kirk J., Fuerstenberg S.M., Zager R.A., Torok-Storb B.: HK-2: An immortalized proximal tubule epithelial cell line from normal adult human kidney. Kidney Int 45: 48-57, 1994.

225. Safirstein R., Price P.M., Saggi S.J., Harris R.C.: Changes in gene expression after temporary renal ischemia.Kidney Int37: 1515-1521,1990.

226. Saito M., Shimizu S., Kinoshita Y. et al. Bladder dysfunction after acute urinary retention in the rats: a novel over active bladder model. Mol Cell Biochem. 2010; 333(1-2): 109-14.

227. Santos, S., Bosch, R.J., Ortega, A., Largo, R., FernándezAgulló, T., Gazapo, R., Egido, J., Esbrit, P. (2001). Kidney International, Vol. 60, № 3, (September 2001), pp. 982-995.

228. Sato M., Muragaki Y., Saika S., Roberts A.B., Ooshima A. Targeted disruption of TGF-1/smad 3 signaling protects against renal tubulointerstitial fibrosis induced by unilateral ureteral obstruction. J Clin Invest 112:1486 -1494, 2003.

229. Saussine C., Judes C., Massfelder T., Musso M.J., Simeoni U., Hannedouche T., Helwig J.J. Stimulatory action of parathyroid hormone on renin 
secretion in vitro: a study using isolated rat kidney, isolated rabbit glomeruli and superfused dispersed rat juxtaglomerular cells. Clin Sci (Lond) 84: 11-19, 1993.

230. Saussine, C., Massfelder, T., Parnin, F., Judes, C., Simeoni, U., and Helwig, J.J. Renin stimulating properties of parathyroid hormone-related peptide in the isolated perfused rat kidney. Kidney Int. 1993; 44: 764-773.

231. Schordan E., Welsch S., Rothhut S., Rothhut S., Lambert A., Barthelmebs M., Helwig J.J., Massfelder T. 2004 Role of parathyroid hormone-related protein in the regulation of stretch-induced renal vascular smooth muscle cell proliferation. J Am Soc Nephrol 15:3016-25.

232. Simeoni, U., Massfelder, T., Saussine, C., Judes, C., Geisert, J., Helwig, J.J. (1994). Involvement of nitric oxide in the vasodilatory response to parathyroid hormone-related peptide in the isolated rabbit kidney. Clin. Sci., 86, 245-249.

233. Simonson M.S. Endothelins: Multifunctional renal peptides. Physiol Rev. 1993; 73: 375-411.

234. Soifer E.N., Van Why, S.K., Ganz, M.B., Kashgarian, M., Siegel, N.J., and Stewart, A.F. Expression of parathyroid hormone-related protein in the rat glomerulus and tubule during recovery from renal ischemia. J Clin Invest. 1993; 92: 2850-2857.

235. Sourbier C., Massfelder T. Parathyroid hormone-related protein in human renal cell carcinoma. Cancer Lett. 2006 28; 240(2):170-82.

236. Steers W.D., Broder S.R., Persson K. et al. Mechanical stretch increases secretion of parathyroid hormone-related protein by cultured bladder smooth muscle cells. J Urol. 1998; 160(3 Pt 1): 908-12.

237. Strewler G.J., Stem P.H., Jacobs J.W. et al. Parathyroid hormonelike protein from human renal carcinoma cells structural and functional homology with parathyroid hormone. J Clin Invest. - 1987; 80: 1803-1807.

238. Strutz F., Neilson E.G.: The role of lymphocytes in the progression of interstitial disease. Kidney Int Suppl 45: S106-S110, 1994.

239. Strutz F., Okada H., Lo C.W., et al. Identification and characterization of a fibroblast marker FSP1. J Cell Biol 1995; 130: 393-405.

240. Strutz, F., Müller, G.A. (2006). Renal fibrosis and the origin of the renal fibroblast. Nephrology, Dialysis, Transplantation, Vol. 21, № 12, (2006), pp. 368-3370.

241. Strutz, F., Neilson, E.G. New insights into mechanisms of fibrosis in immune renal injury.Springer Semin Immunopathol. 2003; 24: 459-476. 
242. Strutz, F., Zeisberg, M., Ziyadeh, F.N., Yang, C.Q., Kalluri, R., Muller, G.A., Neilson, E.G. (2002). Role of basic fibroblast growth factor-2 in epithelial-mesenchymal transformation. Kidney International, Vol. 61, № 5, (May 2002), pp. 1714-1728.

243. Sun J., Xu Y., Deng H., S. Sun, Z. Dai, Y. Sun, Involvement of osteopontin upregulation on mesangial cells growth and collagen synthesis induced by intermittent high glucose // Journal of Cellular Biochemistry, vol. 109, № 6, pp. 1210-1221, 2010.

244. Sutariya B., Jhonsa D. and Saraf M.N. (2016) TGF- $\beta$ : the connecting link between nephropathy and fibrosis. Immunopharmacol. Immunotoxicol. 38, 39-49.

245. Suzuki, Y., Ruiz-Ortega, M., Lorenzo, O. et al. Inflammation and angiotensin II. Int J Biochem Cell Biol. 2003; 35: 881-900.

246. Talon, I.; Lindner, V.; Sourbier, C.; Schordan, E.; Rothhut, S.; Barthelmebs, M.; Lang, H.; Helwig, J.J.; Massfelder, T. Antitumor effect of parathyroid hormone-related protein neutralizing antibody in human renal cell carcinoma in vitro and in vivo. Carcinogenesis 2006, 27, 73-83.

247. Toback F.G.: Regeneration after acute tubular necrosis. Kidney Int 41: 226-246, 1992.

248. Trizna, W., Edwards, R.M. (1991). Relaxation of renal arterioles by parathyroid hormone and parathyroid hormone-related protein. Pharmacology, 42, 91-96.

249. Tsuchiya F., Ikeda I., Kanda F., Fukuoka H. A case of bladder tumor producing granulocyte-colony stimulation factor and parathyroid hormone-related protein. Hinyokika Kiyo. 2001; 47(12): 873-6.

250. Tucci J. and Beck F. (1998) Expression of parathyroid hormonrelated protein $(\mathrm{PTHrP})$ and the $\mathrm{PTH} / \mathrm{PTHrP}$ receptor in the rat uterus during early pregnancy and following artificial deciduoma induction. $\mathrm{J}$ Reprod Fertil 112: 1-10.

251. Turalic, H., Deamant, F.D., Reese, J.H. Paraneoplastic production of granulocyte colony-stimulating factor in a bladder carcinoma. Scand. J. Urol. Nephrol. 2006; 40: 429- 32.

252. Turner P.R., Mefford S., Bambino T., Nissenson R.A. Transmembrane residues together with the amino terminus limit the response of the parathyroid hormone (PTH) 2 receptor to PTH-related peptide. J Biol Chem. 1998; 13; 273(7): 3830-7. 
253. Ueno M., Ban S., Ohigashi T., Nakanoma T., Nonaka S., Hirata R., Iida M., Deguchi N.: Simultaneous production of granulocyte colony-stimulating factor and parathyroid hormone-related protein in bladder cancer. Int J Urol. 2000, 7: 72-75. 10.1046/j.1442-2042.2000.00141.x.

254. Urena P., Kong X.F., Abou-Samra A.B., Juppner H., Kronenberg H.M., Potts J.T. Jr., Segre G.V. Parathyroid hormone (PTH)/PTHrelated peptide receptor messenger ribonucleic acids are widely distributed in rat tissues. Endocrinology. 1993; 133 :617-623.

255. Ureña, P., Kubrusly, M., Mannstadt, M., Hruby, M., Tan, M-M., Silve, C., Lacour, B., Abou-Samra, A-B., Segre, G.V., and Drüeke, T. The renal PTH/PTHrP receptor is down-regulated in rats with chronic renal failure. Kidney Int. 1994; 45: 605-611.

256. Vaidyanathan S., Mansour P., Ueno M., Yamasaki K., Wadhwa M., Soni B.M., Singh G., Hughes P.L., Watson I.D., Sett P.: Problems in early diagnosis of bladder cancer in a spinal cord injury patient: Report of a case of simultaneous production of granulocyte colony stimulating factor and parathyroid hormone-related protein by squamous cell carcinoma of urinary bladder. BMC Urology. 2002, 2: 8-10.1186/1471-2490-2-8.

257. Vaidyanathan S., McCreavy D.T., McDicken I.W. et al. Immunohistochemical study of parathyroid hormone-related protein in vesical transitional epithelium of patients with spinal cord injury. Spinal cord. 1999; 37(11): 760-764.

258. Vaidyanathan S., McDicken I.W., Mansour P. et al. Parathyroid hormone-related protein (1-34) and urothelialredifferentiation in the neuropathic urinary bladder. Spinal Cord. 2000; 38(9): 546-551.

259. Van Why S.K., Hildebrandt F., Ardito T., Mann A.S., Siegel N.J., Kashgarian M.: Induction and intracellular localization of HSP-72 after renal ischemia.Am J Physiol 263: F769-F775, 1992.

260. Varki A. Trousseau's syndrome: Multiple definitions and multiple mechanisms. Blood. 2007; 110:1723-1729. doi: 10.1182/blood-2006-10-053736.

261. Vasavada, R.C., García-Ocaña, A., Massfelder, T., Dann, P., and Stewart, A.F. Parathyroid hormone-related protein in the pancreatic islet and the vascular system. Recent Prog Horm Res. 1998; 53: 305-340.

262. Vielhauer, V., Anders, H.J., Mack, M. et al. Obstructive nephropathy in the mouse: progressive fibrosis correlates with tubulointerstitial 
chemokine expression and accumulation of CC chemokine receptor 2- and 5-positive leukocytes. J Am Soc Nephrol. 2001; 12: 1173-1187.

263. Wang, W., Han, E. Zborowska et al., "Reduced expression of transforming growth factor $\beta$ type I receptor contributes to the malignancy of human colon carcinoma cells," The Journal of Biological Chemistry, vol. 271, № 29, pp. 17366-17371, 1996.

264. Watson P.H., Westhusin, M.E.; and Watson, A.J., Expression of PTHrP and PTHR (PTH/PTHrP-r) mRNAs and polypeptides in bovine ovary and stimulation of bovine blastocyst development in vitro following PTHrP treatment during oocyte maturation. (2001). Obstetrics \& Gynaecology Publications. 61. https://ir.lib.uwo.ca/obsgynpub/61.

265. Watson, P.H., Fraher, L.J., Hendy, G.N., Chung, U.I., Kisiel, M., Natale, B.V., Hodsman, A.B. (2000). Nuclear localization of the type 1 $\mathrm{PTH} / \mathrm{PTHrP}$ receptor in rat tissues. Journal of Bone and Mineral Research, Vol. 15, № 6, (June 2000), pp. 1033-1044.

266. White, K.E., \& Bilous, R.W. (2000). Type 2 diabetic patients with nephropathy showstructural-functional relationships that are similar to type 1 disease. Journal of the American Society of Nephrology, Vol. 11, № 9, (2000), pp. 1667-1673).

267. Williams E.D., Leaver D.D., Danks J.A., Moseley J.M. and Martin T.J. (1994) Effect of parathyroid hormone-related protein (PTHrP) on the contractility of the myometrium and localisation of PTHrP in the uterus of pregnant rats. J Reprod Fertil 102: 209-214.

268. Winquist R.J., Baskin E.P., Vlasuk G.P. Synthetic tumor-derived human hypercalcemic factor exhibits parathyroid hormone-like vasorelaxation in renal arteries. Biochem. Biophys. Res. Commun. 1987; 149: 227-232.

269. Wolf G., Cell cycle regulation in diabetic nephropathy, Kidney Internationa, vol. 58, № 77, pp. S59-S66, 2000.

270. Wolf G., New insights into the pathophysiology of diabetic nephrophathy: from haemodynamics to molecular pathology, European Journal of Clinical Investigation, vol. 34, № 12, pp. 785-796, 2004.

271. Wolf G., Schroeder R., Ziyadeh F.N., F. Thaiss, G. Zahner, and R.A K. Stahl, High glucose stimulates expression of p27(Kip1) in cultured mouse mesangial cells: relationship to hypertrophy, American Journal of Physiology, vol. 273, №3, pp. F348-F356, 1997. 
272. Wolf, G., Ziyadeh, F.N. Molecular mechanisms of diabetic renal hypertrophy. Kidney International, Vol. 56, № 2, (1999), pp. 393-405.

273. Wolf, G., Schroeder, R., Thaiss, F., Ziyadeh, F.N., Helmchen, U., \& Stahl, R.A. (1998). Glomerular expression of p27Kip1 in diabetic $\mathrm{db} / \mathrm{db}$ mouse: role of hyperglycemia. Kidney International, Vol. 53, № 4, (1998), pp. 869-879.

274. Wolzt M., Schmetterer L., Dorner G., Zelger G., Entlicher J., Kapiotis S., Eichler H.G. Hemodynamic effects of parathyroid hormone-related peptide-(1-34) in humans. J. Clin.Endocrinol. Metab. 1997; 82: 2548-2551.

275. Wu S.Z., Yang S.J., Chen H.M., Peng F.F., Yu H., Krepinsky J.C., Zhang B.F. Dual roles of parathyroid hormone related protein in TGF- $\beta 1$ signaling and fibronectin up-regulation in mesangial cells. BiosciRep. 2017 Oct 27; 37(5). pii: BSR20171061. doi: 10.1042/BSR20171061.

276. Xu, Z.G., Yoo, T.H., Ryu, D.R., Cheon Park, H., Ha, S.K., Han, D.S., Adler, S.G., Natarajan, R., \& Kang, S.W. Angiotensin II receptor blocker inhibits p27Kip1 expression in glucose-stimulated podocytes and in diabetic glomeruli. Kidney International. 2005; 67 (3): 944-952.

277. Yamamoto M., Harm S.C., Grasser W.A., Thiede M.A. Parathyroid hormone-related protein in the rat urinary bladder: a smooth muscle relaxant produced locally in response to mechanical stretch. Proc Natl Acad Sci USA 1992; 89(12): 5326-5330.

278. Yang R., Amir J., Liu H., Chaqour B. Mechanical strain activates a program ofgenes functionally involved in paracrine signaling of angiogenesis. Physiol Genomics. 2008; 36(1): 1-14.

279. Yang T., Hassan S., Huang Y.G., Smart A.M., Briggs J.P., Schnermann J.B. Expression of PTHrP, PTH/PTHrP receptor, and $\mathrm{Ca}(2+)-$ sensing receptor mRNAs along the rat nephron. Am. J. Physiol. 1997; 272: F751-758.

280. Yates A.J.P., Gutierrez G.E., Smolens P., Travis P.S., Katz M.S., Aufdemorte T.B., Boyce B.F., Hymer T.K., Poser J.W., Mundy G.R. Effects of a synthetic peptide of a parathyroid hormone-related protein on calcium homeostasis, renal tubular calcium reabsorption, and bone metabolism in vivo and in vitro in rodents. J Clin Invest. 1988; 81: 932-938.

281. Yoshida T., Suzumiya J., Katakami H., Kimura N., Hisano S., Kikuchi M., Okumura M.: Hypercalcemia caused by PTH-rP associated 
with lung metastasis from urinary bladder carcinoma: an autopsied case. Intern Med. 1994; 33: 673-676.

282. Yuan H.T., Li X.Z., Pitera J.E., Long D.A., Woolf A.S.: Peritubular capillary loss after mouse acute nephrotoxicity correlates with down regulation of vascular endothelial growth factor-A and hypoxia-inducible factor-1alpha. Am J Pathol 163: 2289-2301, 2003.

283. Zhuang S., Yan Y., Han J., Schnellmann R.G. (2005). p38 kinasemediated transactivation of the epidermal growth factor receptor is required for dedifferentiation of renal epithelial cells after oxidant injury. Journal of Biological Chemistry. 2005; 280 (22): 21036-21042.

284. Zhuang, S., Dang, Y., \& Schnellmann, R.G. Requirement of the epidermal growth factor receptor in renal epithelial cell proliferation and migration. American Journal of Physiology. Renal Physiology. 2004; 287 (3): F365-F372.

285. Zoja, C., Morigi, M., Figliuzzi, M., Bruzzi, I., Oldroyd, S., Benigni, A., Ronco, P., and Remuzzi, G. Proximal tubular cell synthesis and secretion of endothelin-1 on challenge with albumin and other proteins. Am J Kidney Dis. 1995; 26: 934-941.

286. Zuk A., Bonventre J.V., Brown D., Matlin K.S.: Polarity, integrin and extracellular matrix dynamics in the post-ischemic rat kidney. Am J Physiol.1998; 275: C711-C731.

287. Медведев В.Л., Курзанов А.Н. Роль паратгормон-родственного протеина в патогенезе нарушений сократительной функции мочевого пузыря. Кубанский научный медицинский вестник. 2018; 25(2): 171-177.DOI: 10.25207/1608-6228-2018-25-2-171-177.

288. Семенов Н.Н., В.С. Домбровский, С.Л. Гуторов, Д.А. Филоненко, И.Н. Соколова, М.Р. Личиницер, Степанова У.В. Экспрессия паратироид-подобного протеина и его рецептора при раке почки. Российский биотерапевтический журнал. 2012; 11(4): 63-65.

289. Семенов Р.Р., Степанова Е.В., Личиницер М.Р. Значение экспрессии интегринов avß3 и avß5,паратиреоид-подобного гормона, рецепторов к птпг и остеопонтина в развитии метастазов в кости при раке молочной железы и почки. Российский биотерапевтический журнал. 2011; 10(4): 37-41. 


\section{Гдава 2. ПАРАТГОРМОН-РОДСТВЕННЫЙ ПРОТЕИН И ОРГАНЫ ЖЕНСКОЙ РЕПРОДУКТИВНОЙ СИСТЕМЫ}

\section{1. Паратгормон-родственный белок в тканях матки и плаценты}

ПТГрП экспрессируется и секретируется различными нормальными тканями, включая плаценту человека (Ferguson J.E. et al., 1998; Ferguson J.E. et al., 1992) и нормальный эндометрий (Hoshi S. et al., 2001). Экспрессия ПТГрП наблюдалась в железистых эпителиальных клетках, стромальных и гладкомышечных клетках эндометрия (Casey M.L. et al., 1993; Paspaliaris V. et al., 1992). мРНК рецептора была также обнаружена в нормальном эндометрии человека (Hoshi S. et al., 2001). Характер распределения ПТГрП в нормальном эндометрии предполагает, что этот протеин является секреторным продуктом клеток эндометрия человека хотя его точная фукция в эндометриальной ткани еще не вполне ясна. Индукция экспрессии ПТГрП механическим растяжением, сосудосуживающие эффекты вместе с его способностью расслаблять гладкие мышцы, указывают на аутокринную или паракринную роль в контроле реакций матки человека. Экспрессия ПТГрП в железистом эпителии эндометрия связана с менструальным циклом и более выражена в конце секреторной фазы. Значительно более высокая экспрессия ПТГрП в конце секреторной фазы может также отражать увеличение выделение трансформированного секреторного эндометрия и паракринную роль этого белка в функции и созревании эндометрия.

Mylonas I. et al. (2005) и Hoshi S. et al. (2001) исследовали зависящие от менструального цикла изменения в экспрессии ПТГрП и рецептора PTH1R в эндометрии человека с помощью иммуногистохимии и полимеразной цепной реакции с обратной транскрипцией. Иммуногистохимическая экспрессия ПТГрП наблюдалась в цитоплазме как эпителиальных, так и стромальных клеток. Более сильное окрашивание ПТГрП было обнаружено в железистых 
эпителиальных клетках, чем в стромальных клетках. Окрашивание в течение пролиферативной фазы было более сильным, чем в секреторной фазе. Рецептор PTH1R также присутствовал как в эпителиальных, так и в стромальных клетках эндометрия. Однако не было обнаружено различий в экспрессии рецептора между пролиферативной и секреторной фазами. Данные полимеразной цепной реакции с обратной транскрипцией показали, что экспрессия мРНК ПТГрП была выше во время пролиферативной фазы, чем в секреторной фазе, хотя различий в экспрессии мРНК рецептора PTH1R не наблюдалось. Полученные данные свидетельствуют о том, что пролиферация эндометрия может быть опосредована местным аутокринным и/или паракринным эффектом ПТГрП.

В культуре нормальных стромальных клеток эндометрия эстроген может увеличить уровни мРНК ПТГрП и продукцию белка ПТГрП (Casey M.L. et al., 1993). Экспрессия ПТГрП модулируется трансформирующим фактором роста - бета в нормальных стромальных клетках эндометрия (Casey M.L. et al., 1992). МРНК и белок ПТГрП были обнаружены в эпителии слизистой оболочки эндометрия, в просвете и железах эндометрия, а также в миометрии матки девственных крыс, которые предварительно получали в течение 2 дней бета-эстрадиол-17 (Paspaliaris V. et al., 1992).

Исследование распределения ПТГрП было выполнено в плаценте и мембранах человека с помощью иммуногистохимии с использованием антисывороток к ПТГрП (1-34) и (37-67). (Emly J.F. et al., 1994). ПТГрП был обнаружен в кубических эпителиальных клетках амниона и в цитотрофобластических клетках хориона и материнской децидуальной оболочки. В плаценте ПТГрП (1-34) был обнаружен в синцитиотрофобласте, тогда как активность ПТГрП (37-67) в основном присутствовала на границе кисти синцитиотрофобласта. Это исследование также выявило ПТГрП (37-67), связанное с сосудами плода в плацентарных ворсинках. Молекулярные и иммуноцитохимические исследования продемонстрировали, что ПТГрП экспрессируется крысиными децидуальными клетками и децидуомой. Экспрессия ПТГрП в децидуальных клетках происходит через 48 ч после экспрессии гена в эпителии матки (Beck F. et al., 1993). ПТГрП, был 
обнаружен в интралюминальной маточной жидкости у незрелых крыс, получавших эстрадиол. Поскольку мРНК, кодирующая ПТГрП, ранее была локализована на участках имплантации у беременных крыс, была исследована роль люминального ПТГрП во время беременности. Инфузия антагониста рецептора PTH1R [Asn10, Leu11] амида ПТГрП (7-34) в просвет матки во время беременности у крыс привела к чрезмерной децидуализации. Этот эффект также наблюдался после внутриматочной инфузии моноклонального антитела против ПТГрП. Эффект инфузии антагониста рецептора PTH1R зависел от успешной имплантации и ограничивался обработанным рогом. Снижение количества апоптотических децидуальных клеток в маточных рогах, инфузированных антагонистами, по сравнению с неинфузированными рогами было выявлено иммуногистохимически на 13-й день беременности, и это снижение, вероятно, способствует наблюдаемой «чрезмерной децидуализации». У псевдобеременных крыс вливание антагониста рецептора PTH1R в просвет матки приводило к увеличению массы матки в сыром весе инфузированного рога по сравнению с неинфузированным рогом, что указывает на прямое влияние на формирование децидуомы. Таким образом, активация рецептора PTH1R локально продуцируемым ПТГрП, по-видимому, имеет решающее значение для нормальной децидуализации и имплантации бластоцисты во время беременности крыс (Williams E.D. et al., 1998).

Изучение экспрессии ПТГрП и рецептора PTH1R в матке крысы на ранних сроках беременности и после искусственной индукции децидуомы,проведенное Tucci J., Beck F. (1998) позволило определить паттерны экспрессии ПТГрП и рецептора PTH1R в матке крысы на ранних стадиях нормальной беременности и после искусственной индукции децидуальной реакции. Установлено, что ген рецептора включается на ранних сроках беременности (через 1,5 дня после полового акта) в стромальных клетках эндометрия, которые окружают просвет. Эти клетки включают анти-мезометриальные субэпителиальные стромальные клетки. Этот паттерн продолжается до 5,0 дней после полового акта, когда ПТГрП включается в клетках просветного эпителия, которые выстилают имплантационную камеру. Стромальные клетки, лежащие в основе имплантационной камеры, 
затем подавляют транскрипцию гена рецептора и в течение 12 часов дифференцируются в децидуальные клетки. Аналогичная картина наблюдалась в матке, в которой побочная реакция была вызвана искусственно. Авторы исследования полагают возможным постулировать, что на ранних сроках беременности строма эндометрия инициирует транскрипцию гена для рецептора PTH1R и, таким образом, «подготавливается» для сигнала ПТГрП от клеток эпителия просвета. Через некоторое время после получения сигнала стромальные клетки эндометрия подавляют ген рецептора, и это, по-видимому, запускает терминальную дифференцировку стромальных клеток в децидуальные клетки. Эти результаты позволили предположить, что ПТГрП, действуя через рецептор PTH1R, играет роль в инициации децидуальной реакции во время ранней беременности, регулируя дифференцировку стромальных клеток эндометрия в децидуальные клетки.

Sherafat-Kazemzadeh R. et al. (2011) установили, что ПТГрП подавляет децидуализацию клеток фибробластов матки человека. Уровни мРНК ПТГрП заметно увеличивались в клетках культивируемых человеческих фибробластов матки во время децидуализации in vitro. Результаты этого исследования свидетельствуют, что ПТГрП блокирует индукцию децидуализации и ограничивает степень децидуализации после начала процесса дифференциации. Поскольку экспрессия ПТГрП заметно индуцируется в стромальных клетках матки во время децидуализации, а плацента продуцирует значительное количество ПТГрП, действие этого белка на децидуализацию, скорее всего, связано с аутокринным/паракринным механизмом. ПТГрП может частично действовать путем индукции каспазы 3 через внутренние и внешние апоптотические пути. Авторы этой работы допускают, что ПТГрП имеет действия в стромальных клетках матки в дополнение к регуляции децидуализации и апоптоза и полагают, что агонисты и антагонисты ПТГрП могут быть потенциальными полезными терапевтическими агентами для лечения нарушений децидуализации.

Используя экспериментальную клеточную модель линии клеток мышиного трофобласта, состоящую из четырех типов клеток трофобластного стебля. 
El-Hashash A.H. et al. (2005) исследовали роль ПТГрП в дифференцировке гигантских клеток трофобласта. Анализ влияния экзогенного ПТГрП на вторичные гигантские клетки трофобласта позволил зафиксировать, что эти клетки продуцировали ПТГрП и рецепторы PTH1R in vivo и in vitro. Гигантские клетки трофобласта, обработанные ПТГрП, уменьшали пролиферацию и уменьшали апоптоз, начиная со 2-го дня в культуре, и улучшали свойства дифференциации. Индукция образования гигантских клеток трофобласта с помощью ПТГрП коррелировала с понижающей регуляцией экспрессии циклина В1 и mSNA, но повышала регуляцию циклина D1. Полученные данные свидетельствуют о том, что ПТГрП играет важную роль в дифференциации вторичных гигантских клеток трофобласта во время плацентации. ПТГрП способствует дифференцировке гигантских клеток мышиного вторичного трофобласта посредством индукции эндоцикла, повышающей активность транскрипционных факторов, способствующих росту гигантских клеток, и подавлению других типов клеток трофобластов.

Целью исследований Ramirez M.M. et al. (1995) было определение изменений уровней содержания и локализации пептидных фрагментов ПТГрП в плаценте и эмбриональных мембранах, которые могли бы указывать на их биологическую активность и роль в течение гестационного периода и преждевременных родах. Иммунореактивные ПТГрП (1-34) и ПТГрП (67-86) выявлены в амниотических эпителиальных хорионических трофобластах, децидуальных клеткх и плацентарных синцитиотрофобластах. В эндотелиальной оболочке ворсистых капилляров показано присутствие ПТГрП (67-86), но не ПТГрП (1-34). Эти результаты, показывающие дифференциальную локализацию ПТГрП (1-34) и ПТГрП (67-86), предполагают специфическую обработку предшественника ПТГрП в плаценте человека. Более того, изменения в ПТГрП (1-34), но не ПТГрП (67-86), указывают на особую роль этого пептида в фукционировании матки в процессе родов.

В миометрии ПТГрП продуцируется в ответ на механическое растяжение, имеющее место в матке во время беременности (Thiede M.A. et al., 1990). Ferguson J.E. et al. (1992) получили 
данные характеризующие экспрессию ПТГрП в маточно-плацентарных тканях человека. мРНК ПТГрП была идентифицирована в человеческом амнионе, хорионе, плаценте, децидуальной оболочке и миометрии. Наибольшее присутствие мРНК ПТГрП наблюдали в амнионе (в 10-400 раз больше, чем в других тканях матки). Количество мРНК ПТГрП уменьшалось в амнионе (но не в других тканях) после начала родов. Биоактивность ПТГрП и иммунореактивный ПТГрП в амнионе тесно коррелируют с содержанием мРНК ПТГрП. Амниотическая жидкость содержала ПТГрП $21 \pm 6$ пмоль/л через 16 недель и $41 \pm 9$ пмоль/л через 38 недель гестации. Эти концентрации равнялись или превышали те, которые были обнаружены в плазме пациентов с гиперкальциемией, вторичной по отношению к ПТГрП.

После разрыва плодных мембран мРНК ПТГрП в амнионе уменьшалась на $78 \%$. Подобно мРНК ПТГрП, биоактивность этого белка и иммунореактивный ПТГрП в амнионе значительно снижались после разрыва мембран. Поскольку ПТГрП является мощным антагонистом сокращения мышечной мускулатуры, снижение ПТГрП после разрыва плодных мембран может играть ключевую роль в начале родов.

Результаты исследования количественного определения и сравнения распределения ПТГрП в тканях, полученных в течение периода после спонтанных родов или после кесарева сечения представлены в работе Bowden S.J. et al. (1994). У женщин без самопроизвольных родов в амнионе, покрывающем плаценту, была обнаружена иммунореактивность ПТГрП (1-86) и (37-67). У женщин, рожавших спонтанно, концентрация ПТГрП (1-86) в децидуальной оболочке, выстилающей полость матки, обратно коррелировала с интервалом между разрывом мембран и завершением родов. Концентрация ПТГрП (1-86) была ниже в плаценте, чем в хорионе и амнионе, а во всех тканях концентрации ПТГрП (1-34) и (37-67) были достоверно выше, чем ПТГрП (1-86). Концентрация ПТГрП (1-86) была высокой в амниотической жидкости в срочной гестации, хотя в плазме материнской и пуповинной крови его уровни были только незначительно увеличены. 
Curtis N.E. et al. (1997) изучили тканеспецифическую и временную экспрессию мРНК ПТГрП и иммунореактивного ПТГрП в человеческих гестационных тканях, а также определение влияние родов на экспрессию ПТГрП. Исследовали ткани у женщин, проходящих плановое кесарево сечение (до родов), кесарево сечение во время спонтанного начала родов и женщин со спонтанными родами и нормальными естественными их завершениями. В амнионе над плацентой, отраженном амнионе и в хориодецидуа, как относительная плотность мРНК ПТГрП, так и иммунореактивный белок были значительно увеличены в поздних сроках гестации по сравнению с преждевременными родами. Кроме того, как ПТГрП, так и его мРНК были значительно увеличены в амнионе над плацентой по сравнению с отраженным амнионом. Значительное повышение регуляции мРНК ПТГрП и белка в эмбриональных мембранах в доношенные сроки гестации по сравнению с недоношенными предполагает важную роль этого протеина в поздней человеческой беременности.

Во время человеческой беременности рецепторы PTH1R, продуцируются тканями матки, плаценты, эмбриональных мембран (амнион и хорион) и развивающихся плодов. ПТГрП альтернативный мРНК-сплайсинг приводит к расшифровке транскриптов, которые кодируют три изоформы ПТГрП и идентифицированы в амнионе. Утероплацентарная экспрессия ПТГрП является наибольшей в амнионе и резко возрастает во время поздней беременности. В последующем исследовании Curtis N.E. et al. (1998) определяли экспрессию мРНК рецептора PTH1R на досрочных и срочных гестациях и выявляли альтернативные образцы сплайсинга в плаценте, амнионе и хориодецидуа на досрочных и срочных гестациях. Экспрессия мРНК рецептора PTH1R не различалась между типами тканей и не изменялась с развитием беременности. Напротив, экспрессия ПТГрП в тех же тканях возрастала с увеличением сроков беременности и была значительно выше в амнионе, чем в плаценте и хориодецидуа. Таким образом, ПТГрП, хотя и продуцируется преимущественно в амнионе, может действовать в амнионе и других тканях, включая плаценту,хориодецидуа и миометрий. 


\section{2. Роль паратгормон-родственного белка в модудяции докадьного кровотока матки}

Было показано, что ПТГрП расширяет плацентарные кровеносные сосуды (Heffner L.J. et al., 1999). Наличие локальной системы ПТГрП/РТН1R в маточных артериях убедительно продемонстрировано в исследовании Meziani F. et al. (2008). Авторы в более ранней работе (Meziani F. et al., 2005) сообщали, что экзогенный ПТГрП (1-34) воздействует на гладкие мышцы сосудов через сАМР, способствуя расслаблению маточной артерии у небеременной крысы, тогда как тот же агонист индуцирует почти исключительно эндотелийзависимую релаксацию во время беременности, действуя через оксид азота и эндотелиальные гиперполяризующие факторы. Кроме того, было показано, что релаксация в ответ на ПТГрП (1-34) значительно снижается в маточной артерии у беременных крыс. Этот эффект по мнению авторов мог быть обусловлен, изменениями в сосудистой реактивности матки к ПТГрП связаными с изменением экспрессии рецептора PTH1R. Установлено,что во время развития беременности уменьшается экспресия мРНК рецептора PTH1R, но увеличивается продукция мРНК ПТГрП в маточных артериях. Система ПТГрП/РТН1R сосудистой системы матки адаптируется во время беременности обепечивая участие ПТГрП в регуляции локальной гемодинамики посредством вазорелаксации сосудистых структур, поддерживая адекватное кровоснабжение во время гестации (Mandsager N. et al., 1994). Исследование Meziani F. et al. (2008) было выполнено для лучшего понимания роли ПТГрП (1-34) в механизмах, участвующих в изменениях вазодилатации матки во время беременности. Основные выводы заключались в том, что экспрессия рецептора PTH1R была снижена, тогда как общее количество ПТГрП было увеличено в маточных артериях у беременных крыс. Это было связано с перераспределением системы ПТГрП и его рецептора в этих сосудах. Как белок рецептора, так и экспрессия пептида ПТГрП концентрировались в интимальном слое артерий у беременных крыс. Интересно, что сосудистая система матки адаптируется во время беременности с понижающей регуляцией PTH1R-рецептора и избыточной экспрессией ПТГрП. Перераспределение системы ПТГрП 
и PTH1R-рецептора в артериях матки во время беременности демонстрирует роль эндотелия в реакции ПТГрП в сосудах у беременных крыс. Действительно, экспрессия мРНК PTH1R-рецептора сильно снижается в эндотелиаль-ных маточных артериях у беременных крыс, а в медиальном слое этих сосудов иммуноокрашивание практически отсутствует, тогда как сильная экспрессия белка рецептора PTH1R встречается в эндотелии. Полученные результаты подчеркивают взаимодействие между ПТГрП и СОХ-2 в маточных артериях у беременных крыс. В совокупности эти результаты показывают, что ПТГрП можно рассматривать как один из факторов, регулирующих гемодинамику матки во время беременности, поскольку локальная продукция ПТГрП увеличивается в эндотелии. Чрезмерная экспрессия ПТГрП во время патологических состояний может быть вредным фактором, поскольку она может дополнительно увеличить выделение сосудистого 8-изо-PGF2 $\alpha$ и индуцировать локальный окислительный стресс. Полученные Meziani F. et al. (2008) результаты показывают, что ПТГрП участвует в регуляции локальной гемодинамики матки во время беременности.

\section{3. Вдияние паратгормон родственного белка на функционадьное состояние матки}

Shew R.L. et al. (1991) исследовали in vitro эффект фрагментов ПТГрП (1-34), (38-64) и (67-86) на ацетилхолин-стимулированное сокращение матки крыс. Кроме того, была исследована возможность влияния ПТГрП-(38-64) или (67-86) на релаксацию, вызванную ПТГрП-(1-34). Пептидный домен РТНrP (1-34) дозозависимо уменьшал величину стимулированного ацетилхолином сокращения матки. Фрагменты ПТГрП-(38-64), либо ПТГрП-(67-86) не влияли ни на сокращение матки, стимулированное ацетилхолином ни на релаксацию, вызванную ПТГрП-(1-34). Эти результаты показывают, что миорелаксантная активность ПТГрП связана с первыми $34 \mathrm{~N}$-концевыми аминокислотами.

Эффекты двух различных фрагментов ПТГрП на ацетилхолинстимулированные сокращения матки in vitro были изучены Barri M.E. et al. (1992). В то время как синтетический аналог человеческого 
ПТГрП (75-86 амид) не влиял на функциональное состояние матки, синтетический аналог домена ПТГрП (1-34) в тех же дозах ингибировал, сокращения мышц матки, предварительно стимулированных ацетилхолином.

Было показано, что фрагмент ПТГрП (3-34) не оказывает действия на стимулированные ацетилхолином сокращения миометрия. Также этот фрагмент в эквимолярной концентрации не смог нивелировать эффекты ПТГрП (1-34) на ацетилхолин-стимулированные сокращения матки. Однако 100-кратная избыточная концентрация ПТГрП (3-34) полностью отменила ингибирующее действие ПТГрП (1-34) на ацетилхолин-стимулированные сокращения матки. Эти результаты показывают, что ингибирующее действие ПТГрП (1-34) и ПТГрП (3-34) на сокращение матки зависит от целостности аминоконцевой области молекулы.

Экзогенный ПТГрП (1-34) ингибировал спонтанные и стимулированные электрическими воздействиями сокращения в изолированной матке от нециклирующих крыс. Исследование влияние эстрогена на чувствительность рога матки к ПТГрП показало, что предварительная обработка нециклирующих крыс эстрадиолом-17 бета повышает чувствительность матки к ПТГрП. Рога матки циклирующих крыс в проэструсе и эструсе показали более высокую чувствительность к ПТГрП (1-34) по сравнению с рогами матки, взятыми у крыс при метоэструсе и диэструсе. Это исследование предполагает, что эстрогенное усиление реакции миометрия на ПТГрП может действовать аутокринным и/или паракринным способом, чтобы модулировать подвижность и функцию матки (Paspaliaris V. et al., 1992).

Известно, что ген, кодирующий ПТГрП, регулируется гормональными стероидами, включая эстрогены, 1,25-дигидрокси витамин D и глюкокортикоиды. В то время как эстрогены увеличивает экспрессию гена ПТГрП, 1,25-дигидрокси витамин D и глюкокортикоиды ингибируют транскрипционную активность этого гена. Исследование стероидной регуляции экспрессии и эффектов ПТГрП в матке крысы показало, что введение эстрогенов повышает как уровни мРНК ПТГрП, так и чувствительность гладких мышц в матке овариэктомированных крыс к действию ПТГрП (1-34). Предварительная 
обработка дексаметазоном заметно уменьшала этот эффект эстрогенов. По сравнению с введением животным только эстрогена совместное действие 1,25 -дигидрокси витамина $\mathrm{D}$ и эстрогена увеличивало чувствительность матки к ПТГрП (1-34), в то время как предварительная обработка дексаметазоном и эстрогеном снижала этот ответ. Эти данные указывают на то, что в матке дексаметазон противодействует положительному влиянию эстрогенов на активность гена ПТГрП и дифференциально модулирует действие ПТГрП на тонус миометрия. Кроме того, повышение уровня кортизола в кровотоке в срок может служить как для снижения экспрессии ПТГрП в матке, так и локального действия ПТГрП на миометрий до родов, что способствует сокращению миометрия, связанному с родами (Paspaliaris V. et al., 1995).

Исследование роли ПТГрП в матке (оболочечной железе) птиц Thiede M.A. et al. (1991) позволило установить, что продукция ПТГрП в оболочечной железе в разное время цикла яйцекладки изменяется и уровни ПТГрП временно возрастают по мере того, как яйцо перемещается через яйцевод, постепенно возвращаясь к базальным уровням в течение 15-часового периода кальцификации. Связанные с циклом флуктуации уровней ПТГрП мРНК определяются серозной оболочкой и гладкомышечным слоем. Иммунореактивный ПТГрП локализуется в серозной мембране, а также в гладкомышечном слое серозных артериол, что указывает на то, что ПТГрП может модулировать активность гладких мышц сосудов. В подтверждение этой гипотезы было обнаружено, что синтетический куриный ПТГрП (1-34) расслабляет напряжение покоя изолированных кровеносных сосудов оболочечной железы дозозависимым образом. Вместе эти данные показывают, что экспрессия гена ПТГрП в птичьем яйцеводе регулируется во время цикла яйцекладки, и что ПТГрП может функционировать как аутокринный/паракринный модулятор активности гладкомышечных структур оболочечной железы. Вазорелаксантное свойство N-концевых фрагментов ПТГрП обеспечивает временное увеличение кровотока в оболочечной железе во время кальцификации яиц. 


\subsection{1. Паратгормон-родственный протеин и беременность}

В экспериментах in vitro человеческий ПТГрП (фрагмент 1-34) оказывал расслабляющее действие на ткань миометрия человека и крысы. В миометрии человека чувствительность к ПТГрП снижалась во время беременности и отменялась началом родов (Slattery M.M. et al., 2001). В исследованиях на изолированных полосках миометрия, полученных при кесаревой гистерэктомии беременных бабуинов в последней трети беременности было показано, что ПТГрП (100 нмоль/л), уменьшал как амплитуду, так и частоту сокращения мышечных структур ткани матки (Pitera A.E. et al., 1998). ПТГрП полностью нгибировал сократительный эффект высоких доз окситоцина в нижнем сегменте, корпусе и дне матки бабуина.

В исследованиях на беременных крысах Thiede M.A. et al. (1990) получили данные о том, что ген ПТГрП экспрессируется в миометрии крысы с максимальным пиком экспрессии мРНК ПТГрП, происходящим в течение 48 часов, непосредственно предшествующих рождению. Аналогичный пик в содержании пептида был обнаружен в тканевых экстрактах биологическими и иммунологическими анализами, но ПТРП не был обнаружен в периферическом кровообращении или в плазме крови из маточной вены на поздней стадии беременности. Гистохимически гибридизацией in situ мРНК ПТГрП была продемонстрирована как в продольном, так и в круговом слоях гладкой мускулатуры, но отсутствовала в эндометрии. Увеличение мРНК ПТГрП миометрия на поздней стадии беременности зависело от внутриутробного пребывания плода. В негравидальных рогах матки экспрессия мРНК ПТГрП миометрия была значительно уменьшена или отсутствовала. Эти данные показывают, что экспрессия гена ПТГрП в миометрии находится под контролем локального стимула и предполагают участие этого белка в паракринной или аутокринной регуляции матки в течение периода беременности. Возможно, что ПТГрП может участвовать в контроле ритмичности и/или силы сократительной активности миометрия в дородовой период.

Williams E.D. et al. (1994) исследовали влияние ПТГрП на сократимость сегментов матки, взятых у беременных крыс и локализацию ПТГрП в матке во время беременности. ПТГрП (1-34) оказывал 
сильное ингибирующее действие на спонтанные сокращения продольного слоя миометрия матки, взятого у крыс на 4-й день беременности. Эффект ПТГрП (1-34) на подвижность матки уменьшался по мере того, как беременность прогрессировала до 13 дня, после чего этот фрагмент белка не оказывал заметного влияния на сократимость матки. Напротив, ПТГрП (1-34) не влиял на сокращения круговой гладкой мускулатуры матки на любой стадии беременности. Фрагмент ПТГрП (50-69) не влиял на сократимость мышечного слоя миометрия. Присутствие ПТГрП в матке беременных крыс и его изменения в эндометрии и миометрия были разными в каждом слое. Эти данные свидетельствуют о том, что ПТГрП может иметь по меньшей мере две различные роли в матке: расслабляющее действие на продольные мышцы, которое зависит от гормонального состояния и эффекты связанные с эндометрием.

Выраженная стретч-зависимая экспрессия гена ПТГрП выявлена в матке крыс (Daifotis A.G. et al., 1992). Использование системы внутриматочных баллонов, позволила экспериментально воспроизвести механические эффекты присутствия эмбриона в матке. Увеличение мРНК ПТГрП в незанятом роге односторонне беременной крысы было выявлено так же быстро, как через 1 ч после инфузии баллона, и поддерживалось до 72 часов. Тот же ответ был обнаружен в рогах матки у девственных животных и воспроизведен тремя различными способами ее физического растяжения. Индуцированное баллоном растяжение также увеличивало экспрессию мРНК в мышечной системе in vitro. Механотрансдукция, по-видимому, в значительной степени, если не полностью, ответственна за преждевременный пик экспрессии мРНК ПТГрП в матке.

Гиперкальциемия, вызванная повышенной продукцией ПТГрП репродуктивной системой во время беременности может привести к серьезным осложнениям у плода и матери. Гиперкальциемия может развиться у беременных женщин из-за злокачественных опухолей, продуцирующих ПТГрП (гуморальная гиперкальциемия злокачественных новообразований). ПТГрП вырабатывается физиологически в тканях плода и матери. Плацента и молочные железы продуцируют ПТГрП, и поэтому уровни ПТГрП в сыворотке повышаются 
во время беременности и кормления грудью. Миометрий также может синтезировать ПТГрП, особенно при стимуляции эстрогенами (Bertelloni S. et al., 1994; Thiede M.A. et al., 1991). Чрезмерное производство ПТГрП плацентой, амнионом или молочными железами является редкой причиной гиперкальциемии во время беременности или кормления грудью (Sato K., 2008; Eller-Vainicher C. et al., 2012; Khosla S. et al., 1990).

Хотя незлокачественная гиперкальциемия обычно протекает умеренно описан случай, когда у 28-летней беременной женщины развился гиперкальциемический кризис после нормальных родов. В первый послеродовый день концентрация кальция и ПТГрП в сыворотке крови резко увеличились. После введения физиологического раствора и памидроната сывороточные уровни кальция и ПТГрП быстро нормализовались. Обширное обследование не выявило злокачественного поражения, что позволило автору (Sato K., 2008) предположить, что плацента могла быть источником чрезмерного количества ПТГрП и индуцировать гуморальную гиперкальциемию беременности. Во многом аналогичное наблюдение представили Eller-Vainicher C. et al. (2012). Биохимические исследования показали у женщины на 32-й неделе беременности вввыраженную гиперкальциемию с неопределяемым уровнем гормона околощитовидной железы и заметно повышенным уровнем ПТГрП. Лечение внутривенным введением жидкости не привело к снижению содержания кальция в сыворотке крови. Поэтому было выполнено кесарево сечение для родов. Уровни кальция в сыворотке быстро нормализовались после родов с неопределяемыми уровнями ПТГрП. Авторы пришли к выводу, что эта беременная пациентка страдала гиперкальциемией, ассоциированной с гиперпродукцией ПТГрП, предположительно плацентарного происхождения.

Одной из причин гиперкальциемии беременных может быть перепроизводство ПТГрП тканью молочных желез. Гестационная гигантомастия - это необычное состояние, характеризующееся ненормальным и чрезмерным ростом ткани молочной железы во время неосложненной беременности. Гестационная гигантомастия может сопровождаться гиперкальциемией, которая в некоторых случаях 
связана с повышенным уровнем ПТГрП в сыворотке крови (Khosla S. et al., 1990; Van Wingerden J.J., 2009). Предполагается, что источником ПТГрП в этих случаях является увеличение ткани молочной железы. (Van Heerden J.A., Gharib H., Jackson I.T., 1988; Lepre F. et al., 1993; Moazzami B. et al., 2016).

В недавней публикации был представлен материал, иллюстрирующий вышесказанное (Winter E.M., Appelman-Dijkstra N.M., 2017). У 32-летней женщины на 15-й неделе беременности зафиксировано обширное увеличение молочных желез и боли в животе из-за тяжелой гиперкальциемии, гиперкальциурии и подавленной продукции паратгормона. Гематологические и солидные злокачественные новообразования были исключены. Было установлено, что уровень ПТГрП увеличен в четыре-восемь раз, что является патологическим даже для периода беременности. ПТГрП, как известно, продуцируется в ткани молочной железы, а также в плацентарной ткани, в ответ на активацию рецептора пролактина. Пролактиновая гиперчувствительность тканей молочной железы может вызывать чрезмерную выработку ПТГрП во время беременности. Применение агониста дофаминовых рецепторов бромкриптина для уменьшения секреции пролактина привело к нормализации уровня кальция, а уровни ПТГрП стали необнаружимыми. Доношенный здоровый ребенок родился без нарушений гомеостаза кальция ни непосредственно после рождения, ни через 2 года после наблюдения. Псевдогиперпаратиреоз был вызван повышенной чувствительностью тканей молочной железы к пролактину, которую можно лечить медикаментозно, предотвращая экстренную мастэктомию.

Случай гестационной гигантомастии, зафиксированный у 33-летней женщины на 8-й неделе беременности, с последующим развитием на 13-й неделе выраженной гиперкальциемии описали Modarressi T., et al. (2018). Уровни ПТГ в сыворотке подавлялись, но циркулирующий ПТГрП повышался. Гиперкальциемия плохо реагировала на физиологический раствор, преднизон, кальцитонин и цинакальцет, что потребовало прерывания беременности на 20 неделе. Уровни кальция, ПТГ и ПТГрП в сыворотке крови 
нормализовались в течение 48 часов после прерывания беременности. Быстрое разрешение гиперкальциемии после прерывания беременности, несмотря на сохранившуюся гигантомастию, свидетельствует о возможой роли плаценты в избыточном производстве ПТГрП.

\section{4. Неоплазии матки ассоциированные с паратгормон родственным белком}

В систематическом обзоре Savvari P. et al. (2009) проанализировали 34 опубликованных случая различных гинекологических злокачественных новообразований, осложненных паранеопластической гиперкальциемией, вызванной продукцией ПТГрП. Из 34 зафиксированных случаев у 22 пациенток были диагносцированы новообразования яичников, у 6 злокачественные опухоли матки, у 3 - вульвы и еще у 3 - рак шейки матки. По данным гистологических исследований светлоклеточная карцинома была преобладающим типом опухоли, связанным с экспрессией ПТГрП, учитывая $38 \%$ всех случаев и $50 \%$ случаев злокачественных опухолей матки Значительная корреляция была обнаружена между сывороточным кальцием и уровнями ПТГрП. Лечение гиперкальциемии было успешным в большинстве случаев. У больных раком яичников с тяжелой гиперкальциемией и высокими уровнями ПТГрП в сыворотке выживаемость короче, чем у их пациентов с легкой гиперкальциемией или умеренно повышенными уровнями ПТГрП в сыворотке, но различия не были статистически значимыми.

Используя иммуногистохимическое выявление ПТГрП в эндометрии Mylonas I. et al. (2005) продемонстрировали присутствие этого протеина при гиперпластических и злокачественных изменениях ткани эндометрия. В аденоматозной гиперплазии зафиксировано интенсивное ПТГрП-позитивное иммуноокрашивание. Это может указывать на функциональную роль этого протеина в патогенезе трансформации эндометрия либо путем воздействия на клетки либо путем регулирования маточного кровотока. ПТГрП в наибольшей мере обнаружен в эдометрии при аденоматозной гиперплазия III степени, в то время как самое слабое иммуноокрашивание ткани на ПТГрП зафиксировано в эндометриоидной аденокарциноме. Поскольку 
аденоматозная гиперплазия III степени может рассматриваться как предшественник рака эндометрия, ПТГрП может быть маркером онкотрансформация клеток. Было зарегистрировано лишь несколько случаев карцином эндометрия. Takeuchi K. et al. (2016) сообщили о случае светлоклеточной аденокарциномы эндометрия с гиперкальциемией и продемонстрировали экспрессию ПТГрП в опухолевой ткани на клеточном уровне с помощью иммуногистохимии. Клинически в этом случае не было метастазов в кости и после хирургического удаления матки гиперкальциемия была нивелирована. Подавление секреции интактного паратгормона также подтверждает тот факт, что гиперкальциемия в этом случае опосредована гуморально вследствие секреции ПТГрП, поскольку уровень ПТГрП в сыворотке был повышен.

Иммуногистохимический анализ продемонстрировал экспрессию ПТГрП в $96 \%$ образцов ткани при плоскоклеточном раке шейки матки и более высокая иммунореактивность наблюдалась в случаях кератинизации клеток независимо от уровня кальция в сыворотке крови пациентов. Случаи инвазивных плоскоклеточных карцином с гиперкальциемией были высокоположительными для иммуновыявления ПТГрП и показали выраженное стромальное взаимодействие скиррозного типа. (Kitazawa S., Kitazawa R., Fukase M. et al., 1994). ПТГрП и мРНК ПТГрП наблюдались во всех исследованных образцах ткани опухолей шейки матки. Несмотря на высокую частоту экспрессии ПТГрП, рак шейки матки редко ассоциируется с гуморальной гиперкальциемией злокачественных новообразований, но аутокринные / паракринные эффекты ПТГрП могут иметь важное значение в росте и дифференцировке злокачественных клеток (Dunne F.P. et al., 1994).

Первое сообщение о случае серозной папиллярной карциномы эндометрия с паранеопластической гиперкальциемией, вызванной ПТГрП опубликовали Sachmechi I. et al. (1995). Kinugasa Y. et al. (2006) представили первый зарегистрированный случай ПТГрП индуцированной гиперкальциемии при эндометриоидной аденокарциноме матки. Еще один хорошо документированный случай эндометриоидной аденокарциномы описали Visnyei K. et al. (2011). Анализ 
крови выявил у пациентки повышеные уровни кальция и ПТГрП в сыворотке крови, сниженный уровень паратгормона и 1,25-дигидроксивитамина D. Исследование скелета не выявило признаков множественной миеломы, рентгенография грудной клетки и маммография были нормальными. Гистопатологические исследования подтвердили диагноз эндометриоидной карциномы. Эта комбинация весьма показательна для ассоциированной со злокачественным новообразованием ПТГрП-индуцированной гуморальной гиперкальциемии, поскольку другие потенциальные причины повышенного уровня кальция в сыворотке крови были исключены.

О первом зарегистрированном случае карциносаркомы тела матки, вызывающей ПТГрП-ассоциированную гуморальную гиперкальциемию злокачественных новообразований сообщили Takamatsu S. et al. (2014). Лабораторные тесты показали повышенный уровень кальция в сыворотке и повышенный уровень ПТГрП. Диагноз карциносаркомы, состоящей из плоскоклеточной карциномы в ее эпителиальном компоненте был подтвержден гистологическим исследованием. Необычный случай гуморальной гиперкальциемии у пациентки с светлоклеточным раком эндометрия был представлен в работе Richey D.S., Welch B.J. (2008) Диагностические исследования показали, что у пациентки был первичный гиперпаратиреоз из-за аденомы паращитовидных желез, а также увеличенное количество ПТГрП, вторичного по отношению к ее злокачественному новообразованию. Авторы утверждают, что это первый зарегистрированный случай одновременного выявления у пациентки с раком эндометрия сопутствующего первичного гиперпаратиреоза и гуморальной гиперкальциемией злокачественных новообразований индуцированной ПТГрП.

В недавнем сообщении Nehru V.M. et al. (2017) представили случай паранеопластической гиперкальциемии индуцированной ПТГрП у пациентки с опухолью матки высокой степени злокачественности. Лабораторные исследования продемонстрировали высокие уровни маркера СА125, сывороточного кальция и ПТГрП, пониженный уровень паратгормона и пониженный уровень 25-OH витамина D, что в целом соответствует картине гуморальной гиперкальциемии злокачественных новообразований. Mylonas I., Makovitzky J., Shabani N. 
et al. (2005) продемонстрировали присутствие ПТГрП в нормальной, гиперпластической и злокачественной ткани эндометрия посредством иммуногистохимического окрашивания антител к этому белку. Наибольшая экспрессия ПТГрП наблюдалась при аденоматозной гиперплазии III степени, предшественнике рака эндометрия. Стромальные и миометриальные клетки также показали экспрессию ПТГрП.

Weir E.C. et al. (1994) исследовали в сравнительном плане уровень зкспрессии мРНК ПТГрП в нормальном человеческом миометрии и в ткани миомы матки. Во всех проанализированных образцах выявлена продукция ПТГрП и в большинстве случаев экспрессия ПТГрП была выше в миомах, чем в нормальном миометрии. Культивированные фиброзные клетки также продуцировали более высокие уровни мРНК ПТГрП, чем соответствующие культивируемые нормальные клетки миометрия. В тканевых экстрактах и кондиционированной среде средняя концентрация ПТГрП была значительно выше при исследовании образцов миомы, по сравнению с обычным миометрием. Иммуногистохимическое окрашивание фиброзной ткани и ткани нормального миометрия было положительным для ПТГрП. ПТГрП-(1-34) индуцировал дозозависимое увеличение цАМФ в клетках миометрия in vitro. Эти данные свидетельствуют о том, что ПТГрП может иметь аутокринную/паракринную функцию в регуляции физиологии миометрия и может играть роль в регуляции роста или дифференциации миомы.

Высокий уровнь ПТГрП в сыворотке крови индуцирующий гиперкальциемию при доброкачественных неоплазиях матки встречается крайне редко. Доброкачественные опухоли матки, такие как лейомиома, также могут вызывать гуморальную гиперкальциемию, ассоциированную с высоким уровнем сывороточного ПТГрП и экспрессией этого протеина в ткани миомы (Ravakhah K. et al., 1999). Bilici A. et al. (2004) опубликовали результаты наблюдения пациентки с гуморальной гиперкальциемией, вторичной по отношению к лейомиоме матки, у которой после хирургического удаления новообразования с помощью гистерэктомии нормализовался уровень сывороточного кальция и повышенного уровня ПТГрП. Herring R., Laji K. (2008) представили второй случай доброкачественной 
лейомиомы матки секретирующей ПТГрП. Ассоциация высокого сывороточного уровня кальция и ПТГрП была подтверждена нормализацией уровня кальция после резекции опухоли.

Еще один документированный случай гуморальной гиперкальциемии, связанной с лейомиомой матки, секретирующей ПТГрП, подтверждает вышеприведенную информацию (Dagdelen S. et al., 2008). После хирургического удаления лейомиомы матки уровни сывороточного кальция и ПТГрП нормализовались. Диагноз гуморальной гиперкальциемии доброкачественности, вторичной по отношению к ПТГрП, подтвердился. Сообщено о 36-летней беременной женщине с миомой матки, у которой развился гиперкальциемический кризис в третьем триместре (Rahil A., Khan F.Y., 2012). Основываясь на лабораторных данных, возможным диагнозом была определена гуморальная гиперкальциемия доброкачественности (миома матки), вызванная значительным уровнем ПТГрП. Случай критической гиперкальциемии, связанной с большой лейомиомой был описан у 32-летней женщины на 33 неделе беременности. Послеродовая миомэктомия устранила гиперкальциемию, которая была вызвана ПТГрП, продуцируемым опухолью (Tarnawa E. et al., 2011).

Результаты интересного наблюдения опубликовали Rey E. et al. (2016). На 8-й неделе беременности была обнаружена фиброма матки у 26-летней женщины, которая на 14 неделе была госпитализирована с жалобами на тошноту, рвоту, запор, потерю веса и сильную артралгию в запястьях, руках, коленях и спине. Анализ крови показал повышенные уровни кальция и ПТГрП при очень сниженном сывороточном содержании паратгормона. Медикаментозная коррекция уровня сывороточного кальция была безрезультатна. Принимая во внимание постоянную гиперкальциемию и сохраняющиеся симптомы, заключили, что источником ПТГрП является плацента или фиброма, и после обсуждения с пациенткой было принято решение прервать беременность. После проведенного кюретажа и внутривенного введения памидроната уровни кальция и ПТГрП нормализовались через 2 дня. Гистопатологическое исследование плаценты показало трофобластические и стромальные клетки с сильной иммуногистохимической реактивностью в отношении ПТГрП. Через шесть недель после 
прерывания беременности была выполненания миомэктомия. Артралгия, которая сохранялась с момента прерывания беременности, исчезла в течение 24 часов. Иммуногистохимическое окрашивание на ПТГрП было положительным на более чем $50 \%$ клеток фибромы и показало сильную ядерную и умеренную цитоплазматическую позитивность. Было невозможно определить, был ли сайт максимальной секреции ПТГрП плацентой или фибромой. Таким образом это третий из представленных в литературе случаев гиперпродукции ПТГрП фибромиомой матки верифицированный гистологическими доказательствами того, что фибромы были источником секреции ПТГрП.

По мнению Garcha A.S. et al. (2013) при обнаружении у пациентов констелляции лабораторных данных, включающей повышенные уровни кальция при повышенном ПТГрП, подавленном паратгормоне и низком нормальном уровне витамина D даже в отсутствие выявления четкого очага секреции ПТГрП, лейомиому матки следует рассматривать как возможную причину гиперкальциемии, индуцированную гиперпродукцией ПТГрП, при отсутствии каких-либо других явных злокачественных новообразований. Таким образом, вышеприведенные данные литературы убедительно свидетельствуют о документированных фактах развития гуморальной гиперкальциемии, как при злокачественных опухолях, так и при доброкачественных новообразованиях репродуктивных органов. Гиперкальциемия при доброкачественных новообразованиях определена как синдром гуморальной гиперкальциемии доброкачественности (Knecht T.P. et al., 1996).

\section{5. Яичники и паратгормон родственный бедок}

\subsection{1. Экспрессия и физиологические эффекты паратгормон родственного белка в яичниках}

Экспрессия ПТГрП была продемонстрирована в яичнике развивающейся лягушки (Danks J.A. et. al., 1997) и в яичнике свиньи (Garmey J.C. et al., 2000). Как рецептор PTH1R так и его лиганд ПТГрП были идентифицированы в яичнике крысы (Urena P. et al., 1993; Joun H. et al., 1997). ПТГрП идентифицирован, как компонент фолликулярной жидкости яичника человека и продемонстрировано, что гранулезо-лютеиновые клетки были источником ПТГрП 
(Gutmann J.N. et. al., 1993). В исследовании, сообщающем о ядерной локализации PTH1R, показано, что транскрипты, кодирующие как PTH1R и ПТГрП, так и их полипептиды присутствовали в яичнике крысы (Watson P.H. et al., 2000a). Nowak R.A. et al. (1999) сообщили, что ПТГрП и трансформирующий фактор роста-бетта взаимодействуют, чтобы способствовать разрастанию мышиной бластоцисты, что рассматривается, как участие ПТГрП в роли важного регулятора событий раннего развития.

Watson P.H. et al. (2001) исследовали характер распределение мРНК и полипептидов ПТГрП и РТH1R в бычьем яичнике и влияние введения экзогенного ПТГрП во время созревание бычьих ооцитов in vitro на развития до стадии бластоцисты. Иммунореактивность ПТГрП и PTH1R была изучена в интактных срезах бычьей ткани яичника, чтобы оценить распределение этих полипептидов в бычьем яичнике. Результаты показали, что бычий яичник экспрессирует как мРНК, кодирующие ПТГрП и PTH1R, так и сами эти полипептиды. Рецепторы PTH1R были обнаружены в ооцитах всех фолликулярных стадий. мРНК, кодирующие ПТГрП, были обнаружены методами гибридизации in situ в ооцитах, и гранулезных клетках во всех фолликулах. Положительная иммунореактивность для мРНК PTH1R наблюдался в текальных слоях крупных фолликулов и в строме яичника. Ооциты всех фолликулярных стадий интенсивно иммуноокрашивались на ПТГрП. Рецептор PTH1R, был экспрессирован как в ооцитах, так и в гранулезных клеток бычьего яичника, предполагая, что ПТГрП может действовать как аутокринно, так и паракринно для регулирования развития бычьего фолликула. Добавление в бессывороточную среду для созревания ооцитов ПТГрП (1-141) приводило к зависимому от концентрации усилению развития оплодотворенных бычьих яиц до стадии бластоцисты in vitro. ПТГрП, по-видимому, может быть важным регулятором созревания ооцитов. Позитивное влияние ПТГрП во время созревания ооцитов при образовании бластоцисты возникло после стадии 6-8 клеток. Введение ПТГрП во время созревания ооцитов приводит к значительному увеличению пропорции 6-8 клеточных зигот, прогрессирующих до стадии бластоцисты. 


\subsection{2. Паратгормон родственный белок при раке яичников}

Последние данные литературы свидетельствуют, что приблизительно 5\% гинекологических злокачественных новообразований связаны с паранеопластической гиперкальциемией (Lim D., Oliva E., 2019). Наиболее частой причиной гуморальной гиперкальциемии злокачественных новообразований является ПТГрП, продуцируемый опухолевыми клетками (Stewart A.F. et al., 2005). Рак яичников является наиболее распространенным онкологическим заболеванием женских половых путей, ассоциированным с паранеопластическим синдромом гуморальной гиперкальциемии злокачественных новообразований, который в $80 \%$ наблюдений вызывается ПТГрП, продуцируемым опухолевой тканью (Piura B., 2008). Была обнаружена положительная связь между тяжестью гиперкальциемии и прогрессированием рака яичников. Связь между общими уровнями кальция в сыворотке крови и смертностью от рака яичников была исследована в Третьем национальном обзоре здоровья и питания, который показал, что риск смертельного рака яичников повышается на $52 \%$ на каждые 0,1 ммоль/л увеличения общего уровня кальция в сыворотке (Schwartz G.G., Skinner H.G., 2013).

Гиперкальциемия, развивающаяся вследствие гиперпродукции ПТГрП неопластическими тканями может возникать в связи со многими различными типами рака яичников. Fukunishi H., Yukimura N., Murata K. et al. (1994) провели иммуногистохимическое исследование экспрессии ПТГрП с использованием специфического антитела против ПТГрП в парафиновых срезах 28 различных опухолей яичников: 2 серозных цистаденом, 5 серозных цистаденокарцином, 2 слизистых цистаденом, 2 муцинозные цистаденокарцином, 4 эндометриоидных аденокарцином, 5 светлоклеточных аденокарцином, 1 дисгерминомы, 3 опухолей желточного мешка, 2 зрелых тератом и 2 незрелых тератом. Результаты показали положительное окрашивание в 4 из 5 серозных цистаденокарцином, 2 из 4 эндометриоидных аденокарцином, и во всех образцах светлоклеточных аденокарцином, опухолей желточного мешка и зрелых тератом. Иммуноокрашивание было отрицательным во всех гистологических препаратах при серозной цистаденоме, муцинозной цистаденоме, муцинозной 
цистаденокарциноме, дисгерминоме и незрелой тератоме. Экспрессия ПТГрП, по-видимому, зависит от гистологического типа злокачественности и распространена при светлоклеточной карциноме, серозной цистаденокарциноме и опухоли желточного мешка. Серозная цистаденокарцинома и светлоклеточная карцинома были основными гистологическими подтипами неоплазии яичников, показавшими положительный результат при иммуногистохимическом исследовании экспрессии ПТГрП (Kitazawa R. et al., 1994). Опубликованы данные о различных гистологических подтипах рака яичника ассоциированного с гиперкальцемией индуцированной ПТГрП. Среди злокачественных новообразований яичников светлоклеточная карцинома является наиболее часто ассоциированной с гиперкальциемией (Clement P.B. et al., 1991). Значительно меньше случаев гиперкальциемии, индуцируемых гиперпродукцией ПТГрП диагносцируется при мелкоклеточном, серозном, плоскоклеточном раке и дисгерминоме яичников (Savvari P. et al., 2009).

Развитие гиперкальциемии у пациентки с светлоклеточной карциномой яичника, продуцирующей ПТГрП зафиксировано (Fujino T. et al., 1992). Утверждается, что ПТГрП может быть основной причиной гиперкальциемии, как при первичной, так и при рецидивирующей светлоклеточной карциноме (Young R. et al., 1994). Светлоклеточная аденокарцинома яичника с гиперкальциемией, вызванной повышенным сывороточным содержанием ПТГрП была диагностирована до первичной операции. Лечение динатрия инкадронатом быстро нормализовало уровень кальция в сыворотке крови. Иммуногистохимическое исследование продемонстрировало экспрессию ПТГрП в первичной опухоли яичника. Нозерн-блот-анализ раковых клеток из опухоли яичника подтвердил присутствие мРНК ПТГрП. Таким образом на основе результатов иммуногистохимического и молекулярного анализов было доказано, что гуморальная гиперкальциемия злокачественных новообразований в этом случае обусловлена продуцированием ПТГрП в первичной опухоли яичника (Tsunematsu T. et al., 2000).

Более поздние данные подтверждают, что светлоклеточная карцинома является одним из наиболее распространенных гистологических подтипов опухоли яичника продуцирующего ПТГрП 
(Takagi H. et al., 2011; Lewin S. et al., 2012). Доказано, что светлоклеточный рак является доминирующим гистологическим подтипом, на который приходится $38 \%$ случаев гиперкальциемии, связанных с раком яичников. Дальнейшие исследования показали, что ПТГрП, по-видимому, способствует росту опухоли и метастазированию, что приводит к ее прогрессированию и плохому результату у пациентов (Takada T. et al., 2012; Savvari P. et al., 2009).

Hori M. et al. (2016) представили интересный случай, когда у пациентки с светлоклеточной карциномой предоперационные уровни опухолевых маркеров СА-19-9 и CA-125 были повышены до 270 Ед/мл и 3400 Ед/мл соответственно, но сывороточные уровни кальция и ПТГрП находились в пределах нормальных значений, хотя первичный образец опухоли был иммунопозитивен к ПТГрП. Через 17 лет после первоначальной операции у той же женщины была обнаружена внутрипочечная масса (4-5 см), и лабораторные исследования показали чрезвычайно повышенные сывороточные уровни кальция (14,1 мг/дл) и ПТГрП (21,4 пмоль/л; [в норме $<1,1$ пмоль/л]). Уровни опухолевых маркеров СА-19-9 и СА-125 оставались в пределах нормы. Таким образом у этой пациентки рецидив светлоклеточной карциномы начал продуцировать ПТГрП, вызывая гиперкальциемию и следовательно уровень кальция и ПТГрП в сыворотке могут быть потенциальными индикаторами рецидива, когда уровни опухолевых маркеров не являются стабильными и надежными (Takagi H. et al., 2011).

Kitazawa R. et al. (1997) также сообщили о случае, когда уровень кальция в сыворотке пациентки был повышен только при рецидиве рака, хотя уровни С-концевого домена ПТГрП в сыворотке крови и в моче были удивительно высокими. Иммуногистохимический анализ четко показал локализацию ПТГрП как в первичном, так и в метастатическом участках светлоклеточной карциномы яичника. Транскрипты ПТГрП в легочных метастатических сайтах были выявлены гибридизацией in situ и методом полимеразной цепной реакции с обратной транскрипцией (ОТ-ПЦР). ПТГрП был этиологическим фактором гуморальной гиперкальциемии злокачественных новообразований в этом случае. Поэтому предполагается, что гиперкальциемия 
могла возникнуть после того, как продукция ПТГрП превысила гомеостатический уровень во время терминальной стадии, хотя продукция ПТГрП продолжалась независимо от уровня кальция в сыворотке крови пациента.

Futagami M. et al. (2010) описали случай светлоклеточной карциномы яичника с гиперкальциемией и лейкоцитозом, предположительно возникающих в результате одновременной секреции опухолевой тканью ПТГрП и гранулоцитарного колониестимулирующего фактора (G-CSF), который является главным гемопоэтическим фактором роста, регулирующим гранулоцитопоэз. Это первое сообщение о раке яичника, одновременно продуцирующего ПТГрП и G-CSF, который был подтвержден анализом крови и иммуногистохимическим исследованием. В данном случае зафиксированы высокий лейкоцитоз, гиперкальциемия, повышенный уровень сывороточного ПТГрП и сывороточного G-CSF, которые лишь частично отвечали на медикаментозное лечение и быстро возвратились к нормальному уровню после удаления опухоли яичника. Кроме того, иммуногистохимическое исследование хирургического образца показало, что опухолевая ткань была положительной для ПТГрП, что позволило аргументировать развитие гиперкальциемии влиянием ПТГрП, продуцируемым опухолью яичника. Иммуногистохимическое окрашивание ткани опухоли было положительными и для G-CSF, что явилось свидетельством продукции G-CSF в опухоли и объяснило причину лейкоцитоза.

В недавнем сообщении Ma X. et al. (2018) представили два случая рака яичников связанных с гиперкальциемией, развитие которой обусловлено совершенно разными механизмами. Для выяснения механизма и дифференциальной диагностики были проведены поэтапные клинические и лабораторные исследования. Динамическая компьютерная томография и магнитно-резонансная томография показали двустороннюю как кистозную, так и солидную опухоль яичника. В первом случае лабораторные данные показали высокий уровень в сыворотке крови кальция, антигена СА-125 и 10-кратное превышение нормального показателя ПТГрП, а также выявили сниженное значение уровня паратгормона и гипофосфатемию. Гистопатологическое исследование выявило светлоклеточную аденокарциному 
с метастазированием в сальник. Иммуногистохимическое окрашивание ткани опухоли яичника было положительным для ПТГрП. Сканирование скелета однофотонной эмиссионной компьютерной томографией и сканирование околощитовидной железы не выявили признаков костного метастазирования или гиперплазии околощитовидной железы. Результаты исследования в данном случае указывают на то, что потенциальный механизм гиперкальциемии, связанной с раком яичников с высокой степенью вероятности обусловлен гиперпродукцией ПТГрП тканью опухоли.

Во втором случае ультразвуковое исследование показало увеличенную массу, неоднородность структуры, включающую крупные узловое и кистозное образования. Определен повышенный уровень сывороточного онкомаркера СА-125 и высокий уровень кальция в сыворотке крови. Дополнительные лабораторные данные показали низкий уровень фосфата в сыворотке, высокий уровень 1,25-дигидроксивитамина D $\left[1,25(\mathrm{OH})_{2} \mathrm{D}\right]$ и очень высокое содержание паратгормона в сыворотке. Сцинтиграфическое сканирование выявило поражение левой верхней околощитовидной железы с аномальной концентрацией меченого вещества, что свидетельствует о гиперплазии или аденоме околощитовидной железы. В послеоперационном периоде после левосторонней паратиреоидэктомии сывороточный кальций и паратгормон снизились до нормального уровня. Последующее хирургическое лечение включало полную гистерэктомию с двусторонней сальпингоофоректомией, оментэктомию, биопсию брюшины, тазовую и парааортальную лимфаденэктомию. Микроскопическое исследование показало серозную аденокарциному с метастазированием в сальник. После шести курсов химиотерапии паклитакселом и цисплатином пациентка наблюдалась в течение 18 месяцев без рецидивов. Сделан вывод, что во втором случае выявлена паратгормон-опосредованная гиперкальциемия на фоне аденокарциномы яичника, которая является еще одной распространенной причиной, помимо ПТГрП-индуцированной гуморальной гиперкальциемии злокачественных новообразований. Таким образом представленные в вышеприведенном исследовании пациенты показали сходные клинические проявления, но разные лабораторные 
и клинические результаты из-за различного механизма развития паранеопластических проявлений заболевания.

Экспрессия ПТГрП в яичниках была продемонстрирована также при мелкоклеточном раке яичников ассоциированным с гуморальной гиперкальциемией злокачественных новообразований, который определяют как «Мелкоклеточный рак гиперкальциемического типа», являющегося очень агрессивной опухолью (Eichhorn J.H. et al., 1992; Scully R.E., 1993). Эти опухоли обычно возникают у подростков и молодых женщин. Присутствие ПТГрП в образцах ткани мелкоклеточного рака яичников было изучено иммуногистохимически с использованием поликлонального антитела против синтетического пептида, соответствующего N-концевому домену ПТГрП (1-36). Иммунореактивность к ПТГрП была обнаружена в большинстве изученных образцов ткани мелкоклеточного рака яичников (Matias-Guiu X. et al., 1994).

Первый зарегистрированный случай гиперкальциемии ассоциированной с высоким сывороточным содержанием ПТГрП у пациентки со злокачественной опухолью яичника Бреннера, возникающей в результате зрелой кистозной тератомы, представили Honigberg M.C. et al. (2012). После гистерэктомии с двусторонней сальпингоофоэктомией содержание ПТГрП снизилось до неопределяемого уровня, а кальций нормализовался. Piura B. et al. (2008) сообщили о случае ювенильной гранулезноклеточной опухоли - редкого новообразования яичников, которые обычно встречаются у детей и молодых женщин, связанном с гиперкальциемией. Поскольку уровень паратгормона был в сыворотке был подавлен, а гиперкальциемия не рецидивировала после резекции опухоли, сделан вывод, что гиперкальциемия была вызвана ПТГрП, продуцируемым опухолью.

Хорошо документированный случай плоскоклеточной карциномы, возникающей из зрелой кистозной тератомы яичника, осложненной гиперкальциемией у пациента с высоким уровнем ПТГрП и иммуногистохимическими свидетельствами экспрессии этого белка, опухолевыми клетками представлен в сообщении Takeuchi K. et al. (2000). Плоскоклеточный рак, возникающий из зрелой кистозной тератомы, сам по себе является редким диагнозом, не говоря уже о описании ассоциированной гиперкальциемии, несмотря на то, что 
нормальные кератиноциты продуцируют белок, связанный с паратиреоидным гормоном. В приведенном случае клетки карциномы продуцировали ПТГрП уже в первичной опухоли, хотя уровни кальция в сыворотке крови не были значительно высокими во время операции. Поэтому предполагается, что гиперкальциемия могла возникнуть после того, как продукция ПТГрП преодолела гомеостатический уровень во время терминальной стадии.

Дисгерминомы яичников, которые составляют две трети злокачественных новообразований яичников у детей, являются одним из наиболее распространенных видов рака яичников, связанных с гиперкальциемией обычно индуцируемой синтезом опухолевыми клетками ПТГрП или 1,25-дигидроксивитамина D (1,25 (OH) 2) (Wald A. et al., 2009; Matthew R. et al., 2006; Fleischhacker D.S., Young R.H., 1994; Masahito H. et al., 2008). О случае дисгерминомы яичника с гиперкальциемией и повышенным уровнем ПТГрП в сыворотке крови сообщили (Inoue H. et al., 1995). Незамужняя 18-летняя женщина после хирургического удаления опухоли прошла шесть курсов комбинированной химиотерапии, состоящей из блеомицина, этопозида и цисплатина и не имела признаков рецидива приблизительно через 30 месяцев после завершение химиотерапии.

\section{6. Рак вульвы ассоциированный с паратгормон родственным протеином}

Первый документально подтвержденный случай массивной плоскоклеточной эпителиомы вульвы, осложненной гуморальной гиперкальциемией злокачественных новообразований с высокими концентрациями ПТГрП в сыворотке и иммуногистохимическим подтверждением продукции ПТГрП опухолевыми клетками описан Bilenchi R. et al. (2005).

\section{Дитература к главе 2}

1. Amizuka N., Lee H.S., Kwan M.Y., Arazani A., Warshawsky H., Hendy G.N., Ozawa H., White J.H. and Goltzman D. (1997) Cell-specific expression of the parathyroid hormone $(\mathrm{PTH}) / \mathrm{PTH}-$ related peptide receptor gene in kidney from kidney-specific and ubiquitous promoters. Endocrinology 138: 469-481. 
2. Barri M.E., Abbas S.K., Care A.D. The effects in the rat of two fragments of parathyroid hormone-related protein on uterine contractions in situ. Exp Physiol. 1992; 77(3): 481-90.

3. Beck F., Tucci J., Senior P.V. Expression of parathyroid hormonerelated proteinmRNA by uterine tissues and extraembryonic membranes during gestation in rats. J Reprod Fertil. 1993; 99: 343-352.

4. Bertelloni S., Baroncelli G.I., Pelletti A., Battini R., Saggese G. Parathyroid hormone-related protein in healthy pregnant women. Calcif. Tissue Int. 1994; 54: 195-197.

5. Bilenchi R., Poggiali S., Pisani C., Santopietro R., Miracco C., Vatti R., Lucani B., Andreassi A., Gonnelli S. Malignant hypercalcemia in vulvar cancer. Minerva Ginecol. 2005 Oct; 57(5): 569-74.

6. Bilici A., Doventas A., Karadag B., Hekim N., Tezcan V. Hypercalcemia associated with a uterine leiomyoma: a case report and review of the literature. Gynecol Oncol. 2004 Apr; 93(1): 269-71.

7. Bowden S.J., Emly J.F., Hughes S.V., Powell G., Ahmed A., Whittle M.J., Ratcliffe J.G., Ratcliffe W.A. Parathyroid hormone-related protein in human term placenta and membranes. J Endocrinol. 1994 Aug; 142(2): 217-24.

8. Casey M.L., Mibe M., Erk A., MacDonald P.C: Transforming growth factor-beta 1 stimulation of parathyroid hormonerelated protein expression in human uterine cells in culture:mRNA levels and protein secretion. J Clin Endocrinol Metab 74: 950-952, 1992.

9. Casey M.L., Mibe M. and MacDonald P.C.: Regulation of parathyroid hormone-related protein gene expression in human endometrial stromal cells in culture. J Clin Endocrinol Metab 77: 188-194, 1993.

10. Clement P.B., Young R.H., Scully R.E. Clinical syndromes associated with tumors of the female genital tract. Semin Diagn Pathol. 1991; 8(4): 204-233.

11. Curtis N.E., Ho P.W., King R.G., Farrugia W., Moses E.K., Gillespie M.T., Moseley J.M., Rice G.E., Wlodek M.E. The expression of parathyroid hormone-related protein mRNA and immunoreactive protein in human amnion and choriodecidua is increased at term compared with preterm gestation. J Endocrinol. 1997; 154 (1): 103-112.

12. Curtis N.E., King R. G., Moseley J.M., Ho P.W., Rice G.E., Wlodek M.E. Intrauterine expression of parathyroid hormone-related protein in normal and preeclamptic pregnancies.Placenta 1998; 19: 595-601. 
13. Dagdelen S., Kalan I., Gurlek A. Humoral hypercalcemia of benignancy secondary to parathyroid hormone-related protein secreting uterine leiomyoma. Am J Med Sci. 2008 May; 335(5): 407-8. doi: 10.1097/ MAJ.0b013e3181520125.

14. Daifotis A.G., Weir E.C., Dreyer B.E., Broadus A.E., Stretchinduced parathyroid hormone-related peptide gene expression in the rat uterus. J Biol Chem. 1992 Nov 25; 267(33): 23455-8.

15. Danks J.A., McHale J.C., Martin T.J. and Ingleton P.M. (1997) Parathyroid hormone-related protein in tissues of the emerging frog (Rana temporaria): immunohistochemistry and in situ hybridisation. J Anat 190 (Pt 2): 229-238.

16. Dunne F.P., Rollason T., Ratcliffe W.A., Marshall T., Heath D.A. Parathyroid hormone-related protein gene expression in invasive cervical tumors. Cancer. 1994; 74(1): 83-9.

17. Eichhorn J.H., Bell D.A., Young R.H., Swymer C.M., Flotte T.J., Preffer R.I., Scully R.E. DNA content and proliferative activity in ovarian small cell carcinomas of the hypercalcemic type. Implications for diagnosis, prognosis, and histogenesis. Am J Clin Pathol. 1992; 98: 579-86.

18. El-Hashash A.H., Esbrit P., Kimber S.J. PTHrP promotes murine secondary trophoblast giant cell differentiation through induction of endocycle, upregulation of giant-cellpromoting transcription factors and suppression of other trophoblast cell types. Differentiation.2005; 73, Issue 4: 154-174. DOI:10,1111/j.1432-0436.2005.00013.x.

19. Eller-Vainicher C., Ossola M.W., Beck-Peccoz P., Chiodini I. PTHrP-associated hypercalcemia of pregnancy resolved after delivery: a case report. Eur J Endocrinol. 2012; 166(4):753-756. doi: 10.1530/ EJE-11-1050.

20. Emly J.F., Gregory J., Bowden S.J., Ahmed A., Whittle M.J., Rushton D.I., Ratcliffe W.A. Immunohistochemical localization of parathyroid hormone-related protein (PTHrP) in human term placenta and membranes. Placenta. 1994; 15(6): 653-660.

21. Ferguson J.E., Gorman J.V., Bruns D.E., Weir E.C., Burtis W.J., Martin T.J. and Bruns M.E.: Abundant expression of parathyroid hormone-related protein in human amnion and its association with labor. Proc Natl Acad Sci USA. 1992; 89: 8384-8388. 
22. Ferguson J.E., Seaner R.M., Bruns D.E., Iezzoni J.C. and Bruns M.E.: Expression and specific immunolocalization of the human parathyroid hormone/parathyroid hormone-related protein receptor in the uteroplacental unit. Am J Obstet Gynecol 179: 321-329, 1998.

23. Fleischhacker D.S., Young R.H. Dysgerminoma of the Ovary Associated with Hypercalcemia. Gynecologic Oncology,1994; Volume 52, Issue 1, 87 - 90.

24. Fujino T., Watanabe T., Yamaguchi K., Nagasaki K., Onishi E., Iwamoto I., Dozono H., Nagata Y.The development of hypercalcemia in a patient with an ovarian tumor producing parathyroid hormone-related protein. Cancer. 1992 Dec 15; 70(12): 2845-50.

25. Fukunishi H., Yukimura N., Murata K., Gotoh A., Kitazawa R., Kitazawa S. Immunohistochemical study on the expression of parathyroid hormone-related protein in ovarian tumors. J Bone Miner Metab (1994) 12(Suppl 1): S153-155. https://doi.org/10.1007/BF02375694.

26. Futagami M., Yokoyama Y., Wakui M., Taniguchi R., Higuchi T., Mizunuma H. A Case of Ovarian Clear Cell Carcinoma Simultaneously Producing Parathyroid Hormone-related Protein and Granulocyte Colony-Stimulating Factor. World J Oncol. 2010 Jun; 1(3): 138-141. doi: 10.4021/wjon2010.06.214w.

27. Garcha A.S., Gumaste P., Cherian S., and Khanna A. 2013. Hypercalcemia: an unusual manifestation of uterine leiomyoma. Case Reports in Medicine. Vol. 2013, Article ID 815252, 2 pages.http://dx.doi. org/10.1155/2013/815252.

28. Garmey J.C., Schnorr J.A., Bruns M.E., Bruns D.E., Seaner R.M., Ferguson J.E., Jayes F.C.L., Aquirre C., and Veldhuis J.D. (2000) Expression of parathyroid hormone-related peptide (PTH-rp) and its receptor in the procine ovary: regulation by transforming growth factor- and possible paracrine effects of granulose cell PTH-rp secretion on theca cells. Biol Reprod 62: 334-339.

29. Gutmann J.N., Burtis W.J., Dreyer B.E., Andrade-Gordon P., Penzias A.S., Polan M.L. and Insogna K.L. (1993) Human granulosa-luteal cells secrete parathyroid hormone-related protein in vivo and in vitro. J Clin Endocrinol \& Metab 76: 1314-1318.

30. Heffner L.J., Kumari M. and Benoit L.A.: Secretion of the vasoactive peptides, endothelin, and parathyroid hormonerelated peptide, by 
decidual explants from pregnancies complicated by intrauterine growth restriction. J Soc Gynecol Investig 6: 273-277, 1999.

31. Herring R., and Laji K. Humoral hypercalcaemia of benignancy. A case report. QJM: An International Journal of Medicine.2008; 101(4): 329-30.DOI: 10.1093/qjmed/hcn010.

32. Honigberg M.C., Bradford L.S., Prabhakar A.M., Hariri L.P., Goodman A. Hypercalcemia Associated with a Malignant Brenner Tumor Arising from a Mature Cystic Teratoma. Case Rep Oncol. 2012 Sep-Dec; 5(3): 592-600. doi: 10.1159/000345294.

33. Hori M., Takagi I., Matsunami K., Ichigo S., Imai A. Ectopic Hormone Production from Ovarian Tumor: A Review. Open Journal of Obstetrics and Gynecology.2016; 06(04): 252-258.

34. Hoshi S., Morimoto T., Saito H., Ichizuka K., Matsuoka R., Yanaihara A., Suzuki M., Yanaihara T. and Okai T.: PTHrP and PTH/PTHrP receptor expressions in human endometrium. Endocr J 48: 219-225, 2001.

35. Inoue H., Kikuchi Y., Hirata J., Wada S., Seki K. and Nagata I. (1995) Dysgerminoma of the ovary with hypercalcemia associated with elevated parathyroid hormone-related protein. Jap J Clin Oncol. 25: 113-117.

36. Joun H., Lanske B., Karperien M., Qian F., Defize L. and AbouSamra A. (1997) Tissue-specific transcription start sites and alternative splicing of the parathyroid hormone (PTH)/PTH-related peptide (PTHrP) receptor gene: a new PTH/PTHrP receptor splice variant that lacks the signal peptide. Endocrinology 138: 1742-1749.

37. Khosla, S., Van Heerden, J.A., Gharib, H., Jackson, I.T., Danks, J., Hayman, J.A., \& Martin, T.J. (1990). Parathyroid hormone-related protein and hypercalcemia secondary to massive mammary hyperplasia. New England Journal of Medicine, 322(16), 1157.

38. Kinugasa Y., Morishige K., Kamiura S., Tsukamoto Y., Saji F. Parathyroid hormone-related protein-secreting uterine endometrioid adenocarcinoma. Japanese Journal of Clinical Oncology. 2006; 36(2): 113-5. DOI: 10.1093/jjco/hyi215.

39. Kitazawa R., Kitazawa S., Fukunishi, H. et al. Clinicopathological relevance of parathyroid hormone-related protein in various types of cancer tissues. J Bone Miner Metab. 1994; 12(1): S145. https://doi. org/10.1007/BF02375693. 
40. Kitazawa S., Kitazawa R., Fukase M. et al. Immunohistochemical evaluation of parathyroid hormone-related protein (PTHrP) in the uterine cervix. Int. J Cancer. 1992; 50: 731-735.

41. Kitazawa, R., Kitazawa, S., Matui, T. and Maeda, S. (1997) In situ Detection of Parathyroid Hormone-Related Protein in Ovarian Clear Cell Carcinoma. Human Pathology, 28, 379-382. http://dx.doi. org/10.1016/S0046-8177(97)90139-8.

42. Knecht T.P., Behling C.A., Burton D.W., Glass C.K., Deftos L.J. The Humoral Hypercalcemia of Benignancy: A Newly Appreciated Syndrome, Amer. J. of Clinical Pathology. 1996; 105 (4): 487-492. https:// doi.org/10.1093/ajcp/105.4.487.

43. Lepre F., Grill V., Ho P.W., Martin T.J. Hypercalcemia in pregnancy and lactation associated with parathyroid hormone-related protein. $\mathrm{N}$ Engl J Med. 1993; 328(9): 666-7.

44. Lewin S., Dezube D., Guddati A.K., Mittal K., Muggia F., Klein P. Paraneoplastic hypercalcemia in clear cell ovarian adenocarcinoma. Ecancermedicalscience. 2012; 6: 271. doi: 10.3332/ecancer.2012.271.

45. Lim D., Oliva E., Gynecological Neoplasms associated with Paraneoplastic Hypercalcemia, Seminars in Diagnostic Pathology, 10.1053/j. semdp.2019.01.003, (2019).

46. Ma X., Wang Y., Zhang X., Dong M., Yang W., Xue F. Ovarian cancer presenting with hypercalcemia: two cases with similar manifestations but different mechanisms. Cancer Biol Med. 2018 May; 15(2): 182187. doi: 10.20892/j.issn.2095-3941.2018.0009.

47. Mandsager N., Brewer A., and Myatt L. (1994). Vasodilator effects of parathyroid hormone, parathyroid hormone-related protein, and calcitonin gene-related peptide in the human fetal-placental circulation. J. Soc. Gynecol. Investig. 67: 1263-1269.

48. Masahito H., Hara F., Tomishige H., Nishida Y., Kato T., Okumura N., Hashimoto T., Kato R. (2008) 1,25-dihydroxyvitamin d-mediated hypercalcemia in ovarian dysgerminoma. Pediatric Hematology and Oncology, 25:1, 73-78, DOI: 10.1080/08880010701774033.

49. Matia-Guiu X., Prat J., Young R.H., Capen C.C., Rosol T.J., Delellis D.A., Scully R.E. (1994) Human parthyroid hormone-related protein in ovarian small cell carcinoma. An immunohistochemical study. Cancer 73:1878-1881. 
50. Matthew R., O. Christopher, and S. Philippa, Severe malignancyassociated hypercalcemia in dysgerminoma, Pediatric Blood \& Cancer, vol. 47, № 5, pp. 621-623, 2006.

51. Meziani F., Tesse A., Welsch S., Kremer H., Mariette Barthelmebs, Ramaroson Andriantsitohaina, Francis Schneider, Alexis Gairard. Expression and Biological Activity of Parathyroid Hormone-Related Peptide in Pregnant Rat Uterine Artery: Any Role for 8-Iso-Prostaglandin F2 $\alpha$ ?, Endocrinology 2008; 149(2): 626-633.

52. Meziani F., Van Overloop B., Schneider F., Gairard A. Parathyroid hormonerelated protein-induced relaxation of rat uterine arteries: influence of the endothelium during gestation. J Soc Gynecol Investig. 2005; 12: 14-19.

53. Moazzami B., Chaichian S., Farahvash M.R., Taheri S., Ahmadi S.A., Mokhtari M., Sheibani K.A. Rare Case of Gestational Gigantomastia with Hypercalcemia: The Challenges of Management and Follow up. J Reprod Infertil. 2016 Oct-Dec; 17(4): 243-246.

54. Modarressi T., Levine M.A., Tchou J., Khan A.N. Gestational Gigantomastia Complicated by PTHrP-Mediated Hypercalcemia. The Journal of Clinical Endocrinology \& Metabolism.2018: 103(9): 31243130. https://doi.org/10.1210/jc.2018-01181.

55. Mylonas I., Makovitzky J., Shabani N,, Richter D-U., Jeschke U., Briese V. Friese K. Parathyroid hormone-related peptide (PTH-rp) in normal, hyperplastic and malignant endometrial tissue: An immunohistochemical analysis. Anticancer Res. 2005; 25: 1633-1638.

56. Nehru V.M., Garcia G., Ding J., Kong F., Dai Q. Humoral Hypercalcemia in Uterine Cancers: A Case Report and Literature Review. Am J Case Rep. 2017; 18: 22-25. doi: 10.12659/AJCR.900088.

57. Nowak R.A., Haimovici F., Biggers J.D., and Erbach G.T. (1999) Transforming growth factor- stimulates mouse blastocyst outgrowth through a mechanism involving parathyroid hormone-related protein. Biol Reprod 60: 85-93.

58. Paspaliaris V., Petersen D.N., Thiede M.A. Steroid regulation of parathyroid hormone-related protein expression and action in the rat uterus. J Steroid Biochem Mol Biol. 1995; 53(1-6): 259-65.

59. Paspaliaris V., Vargas S.J., Gillespie M.T., Williams E.D., Danks J.A., Moseley J.M., Story M.E., Pennefather J.N., Leaver D.D., Martin T.J. 
Oestrogen enhancement of the myometrial response to exogenous parathyroid hormone-related protein (PTHrP), and tissue localization of endogenous PTHrP and its mRNA in the virgin rat uterus. J Endocrinol. 1992; 134(3): 415-425.

60. Pitera A.E., Smith G.C., Wentworth R.A., Nathanielsz P.W. Parathyroid hormonerelated peptide (1 to 34) inhibits in vitro oxytocin-stimulated activity of pregnant baboon myometrium. Am J Obstet Gynecol. 1998; 179(2): 492-6.

61. Piura B. Hypercalcemia in malignancies of the female genital tract. Harefuah. 2008 Mar; 147(3): 229-34, 277.

62. Piura B., Wiznitzer A., Shaco-Levy R. Juvenile granulosa cell tumor of the ovary associated with hypercalcemia. Arch Gynecol Obstet. 2008 Mar; 277(3): 257-62.

63. Rahil A., and Khan F.Y. 2012. Humoral hypercalcemic crisis in a pregnant woman with uterine leiomyoma. J. Emerg. Trauma Shock 5:87-89.

64. Ramirez M.M., Fraher L.J., Goltzman D., Hendy G.N., Matthews S.G., Sangha R., Challis J.R. Immunoreactive parathyroid hormone-related protein: its association with preterm labor. European Journal of Obstetrics, Gynecology, and Reproductive Biology. 1995, 63(1): 21-26. DOI: 10.1016/0301-2115(95)98586-S.

65. Ravakhah K., Gover A., Mukunda B.N. Humoral Hypercalcemia Associated with a Uterine Fibroid. Ann Intern Med. 1999; 130: 702. doi: 10.7326/0003-4819-130-8-199904200-00011.

66. Rey E., Jacob C-E., Koolian M., Morin F. Hypercalcemia in pregnancy - a multifaceted challenge: case reports and literature review. Clin Case Rep. 2016; 4(10): 1001-1008. doi: 10.1002/ccr3.646.

67. Richey D.S., Welch B.J. Concurrent primary hyperparathyroidism and humoral hypercalcemia of malignancy in a patient with clear cell endometrial cancer. South Med J. 2008 Dec; 101(12): 1266-8. doi: 10.1097/SMJ.0b013e318181d59d.

68. Sachmechi, I., Kalra, J., Molho, L. and Chawla, K. (1995) Paraneoplastic Hypercarcemia Associated with Uterine Pa-pillary Serous Carcinoma. Gynecologic Oncology, 58, 378-382. http://dx.doi.org/10.1006/gyno.1995.1246.

69. Sato K. Hypercalcemia during pregnancy, puerperium, and lactation: review and a case report of hypercalcemic crisis after delivery due 
to excessive production of PTH-related protein (PTHrP) without malignancy (humoral hypercalcemia of pregnancy). Endocr. J. 2008; 55: 959-966.

70. Savvari P., Peitsidis P., Alevizaki M., Dimopoulos M., Antsaklis A. and Papadimitriou C. Paraneoplastic Humorally Mediated Hypercalcemia Induced by Parathyroid Hormone-Related Protein in Gynecologic Malignancies: A Systematic Review. Onkologie. 2009; 32: 517-523. doi. org/10.1159/000226209.

71. Schwartz G.G., Skinner H.G. Prospective studies of total and ionized serum calcium in relation to incident and fatal ovarian cancer. Gynecol Oncol. 2013;129:169-72).

72. Scully R.E. Small cell carcinoma of hypercalcemic type. Int J Gynecol Pathol. 1993;12:148-52. doi: 10.1097/00004347-199304000-00010.

73. Sherafat-Kazemzadeh R., Schroeder J.K., Kessler C.A., Handwerger S. Parathyroid Hormone-Like Hormone (PTHLH) Represses Decidualization of Human Uterine Fibroblast Cells by an Autocrine/Paracrine Mechanism. J Clin Endocrinol Metab. 2011; 96(2): 509-514.

74. Shew R.L., Yee J.A., Kliewer D.B. et al. Parathyroid hormonerelated protein inhibits stimulated uterine contraction in vitro. J Bone Miner Res. 1991 Sep; 6(9): 955-9.

75. Slattery M.M., O'leary M.J., Morrison J.J. Effect of parathyroid hormone-related peptide on human and rat myometrial contractility in vitro. Am J Obstet Gynecol. 2001; 184(4): 625-9.

76. Stewart A.F. Clinical practice. Hypercalcemia associated with cancer. N Engl J Med. 2005; 352(4): 373-379. doi: 10.1056/NEJMcp042806.

77. Takada T., Iwase H., Iitsuka C., Nomura H., Skamaoto K., Omatsu K., Takeshima N., Takizawa K. Adjuvant chemotherapy for stage I clear cell carcinoma of the ovary: an analysis of fully staged patients. Int $\mathrm{J}$ Gynecol Cancer. 2012; 22: 573-8. doi: 10.1097/IGC.0b013e31823fd413.

78. Takagi, H., Matsunami, K., Ichigo, S., Hamada, T., Murase, T., Ikeda, T. and Imai, A. (2011) Ovarian Clear Cell Carcinoma Changing to Produce Parathyroid Hormone-Related Protein with the Recurrence. Journal of Gynecologic Surgery, 27, 277-279. http://dx.doi.org/10.1089/ gyn.2010.0066. 
79. Takamatsu S., Matsumura N., Baba T., Mandai M., Mikami Y., Konishi I. Humoral hypercalcemia caused by uterine corpus carcinosarcoma consisting of squamous cell carcinoma in its epithelial component. J Obstet Gynaecol Res. 2014 Jan; 40(1): 263-7. doi: 10.1111/jog.12136.

80. Takeuchi K., Murata K., Funaki K., Kitazawa S., Kitazawa R. Immunohistochemical detection of parathyroid hormone-related protein in a squamous cell carcinoma arising from mature cystic teratoma causing humoral hypercalcemia of malignancy. Gynecol Oncol. 2000 Dec; 79(3): 504-7.

81. Takeuchi K., Shirakuni A., Yoshida A., Takeda A. and Sugimoto M. Hypercalcemia Due to Parathyroid Hormone-Related Protein Induced by Primary Endometrial Clear Cell Adenocarcinoma: Case Report. Open Journal of Obstetrics and Gynecology, 2016; 6: 521-524. http:// dx.doi.org/10.4236/ojog.2016.69066.

82. Tarnawa E., Sullivan S., Underwood P., Richardson M., Spruill L. Severe hypercalcemia associated with uterine leiomyoma in pregnancy. Obstet Gynecol. 2011 Feb; 117(2 Pt 2): 473-6. doi: 10.1097/ AOG.0b013e3181fd29ae.

83. Thiede M.A., Harm S.C., Hasson D.M., and Gardner R.M. In vivo regulation of parathyroid hormone-related peptide messenger ribonucleic acid in the rat uterus by 17 beta-estradiol. Endocrinology. 1991; 128: 2317-2323.

84. Thiede M.A., Daifotis A.G., Weir E.C., Brines M.L., Burtis W.J., Ikeda K., Dreyer B.E., Garfield R.E., Broadus A.E. Intrauterine occupancy controls expression of the parathyroid hormone-related peptide gene in preterm rat myometrium. Proc Natl Acad Sci U S A 1990; 87: 6969-6973.

85. Thiede M.A., Harm S.C., McKee R.L. et al. Expression of the parathyroid hormone-related protein gene in the avian oviduct: potential role as a local modulator of vascular smooth muscle tension and shell gland motility during the egg-laying cycle. Endocrinology.1991; 129(4): 1958-66.

86. Tsunematsu, T., T. Saito, H. Iguchi, T. Fukuda, and N. Tsukamoto. Hypercalcemia due to parathyroid hormone-related protein produced by 
primary ovarian clear cell adenocarcinoma: case report. Gynecol Oncol 2000. 76: 218-222.

87. Tucci J., Beck F. Expression of parathyroid hormone-related protein (PTHrP) and the PTH/PTHrP receptor in the rat uterus during early pregnancy and following artificial deciduoma induction. J Reprod Fertil. 1998; 112(1): 1-10.

88. Urena P., Kong S.-F., Abou-Samra A.-B., Juppner H., Kronenberg H.M., Potts Jr. J.T. and Segre G.V. (1993) Parathyroid hormone (PTH)/PTH-related peptide receptor messenger ribonucleic acids are widely distributed in rat tissues. Endocrinology 133: 617-623.

89. Van Heerden J.A., Gharib H., Jackson I.T. Pseudohyperparathyroidism secondary to gigantic mammary hypertrophy. Arch Surg. 1988; 123(1): 80-2.

90. Van Wingerden J.J. Gigantomastia--definition and association with hypercalcaemia. J Plast Reconstr Aesthet Surg. 2009; 62(1): 112-4; doi: 10.1016/j.bjps.2008.06.019.

91. Visnyei K., Shahrokni S., Hashmi S., Orell J., Wild D.M.G. A case of groans, moans and stones with malignant undertones: Endometrioid carcinoma-associated hypercalcemia. Oncology letters. 2011; 3(11): 335337. doi.org/10.3892/ol.2011.475.

92. Wald A., Narasimhan S., Nieves-Arriba L., Waggoner S. Prolonged Hypercalcemia Following Resection of Dysgerminoma: A Case Report. Obstetrics and Gynecology International. Volume 2009, Article ID 956935, 3 pages http://dx.doi.org/10.1155/2009/956935.

93. Watson P.H., Westhusin, M.E.; and Watson, A.J. Expression of PTHrP and PTHR (PTH/PTHrP-r) mRNAs and polypeptides in bovine ovary and stimulation of bovine blastocyst development in vitro following PTHrP treatment during oocyte maturation. (2001). Obstetrics \& Gynaecology Publications. 61. https://ir.lib.uwo.ca/obsgynpub/61.

94. Watson P.H., Fraher L.J., Hendy G.N., Chung U.-I., Kisiel M., Natale B.V. and Hodsman A.B. (2000a) Nuclear localization of the type $1 \mathrm{PTH} / \mathrm{PTHrP}$ receptor in rat tissues. J Bone Min Res 15 (6): 1033-1044.

95. Watson P.H., Fraher L.J., Natale B.V., Kisiel M., Hendy G.N. and Hodsman A.B. (2000b) Nuclear localization of the type $1 \mathrm{PTH} /$ 
PTHrP receptor in MC3T3-E1 cells: association with the cell cycle. Bone 26 (3): 221-225.

96. Weir E.C., D.L. Goad, A.G. Daifotis, W.J. Burtis, B.E. Dreyer, and R.A. Nowak, Relative overexpression of the parathyroid hormone-related protein gene in human leiomyomas, Journal of Clinical Endocrinology and Metabolism, vol. 78, № 3, pp. 784-789, 1994.

97. Williams E.D., Leaver D.D., Danks J.A. et al. Effect of parathyroid hormone-related protein (PTHrP) on the contractility of the myometrium and localization of PTHrP in the uterus of pregnant rats. Journal of reproduction and fertility. 1994; 102(1) 209-14.

98. Williams E.D., Major B.J., Martin T.J., Moseley J.M., Leaver D.D. Effect of antagonism of the parathyroid hormone (PTH)/PTHrelated protein receptor on decidualization in rat uterus. J Reprod Fertil. 1998; 112(1):59-67.

99. Winter E.M., Appelman-Dijkstra N.M. Parathyroid HormoneRelated Protein-Induced Hypercalcemia of Pregnancy Successfully Reversed by a Dopamine Agonist. J Clin Endocrinol Metab. 2017; 102(12): 4417-4420. doi: 10.1210/jc.2017-01617.

100. Yang T., Hassan S., Huang Y.G., Smart A.M., Briggs J.P. and Schnermann J.B. (1997) Expression of PTHrP, PTH/PTHrP receptor, and $\mathrm{Ca}(2+)$-sensing receptor $\mathrm{mRNAs}$ along the rat nephron. Amer $\mathrm{J}$ Physiol 272:F751-F758.

101. Young, R., Oliva, E. and Scully, R. (1994) Small Cell Carcinoma of the Ovary, Hypercalcemic Type. A Clinicopathological Analysis of 150 Cases. American Journal of Surgical Pathology, 18, 1102-1116. http:// dx.doi.org/10.1097/00000478-199411000-00004. 


\section{Гдава 3. ПАРАТГОРМОН РОДСТВЕННЫЙ БЕЛОК И ОРГАНЫ МУЖСКОЙ РЕПРОДУКТИВНОЙ СИСТЕМЫ}

\subsection{1. Паратгормон родственный бедок в нормальной ткани простаты}

3.1. Предстательная железа и паратгормон родственный белок

Все три первоначальные изоформы ПТГрП, образующиеся за счет альтернативного сплайсинга генов человека, присутствуют в нормальной ткани простаты, (Wu G.1. et al., 1998). Все изоформы ПТГрП обнаружены в нормальной ткани предстательной железы дифференциальной ПЦР-РВ. Дальнейший анализ с использованием в гибридизации экзон-специфических зондов показал, что все три изоформы ПТГрП присутствовали в нейроэндокринных клетках предстательной железы в которых они и продуцируются (Iwamura M. et al., 1994b; Wu G. et al., 1998). ПТГрП может выступать в роли паракринного, аутокринного и интракринного фактора, регулирущего рост и дифференциацию клеток предстательной железы (Asadi F., Kukreja S., 2005).

Методом ферментного коньюгирования с использованием моноклональных антител против $\mathrm{N}$-терминального фрагмента (1-34) ПТГрП продемонстрировано присутствие этого белка в цитозоле эпителиальных клеток нормальной ткани простаты (Iwamura M. et al., 1994b). Было установлено, что локализация и продукция ПТГрП в простатических нейроэндокринных клетках может являться эндокринно-паракринным фактором, участвующим в росте и дифференциации ткани простаты (Asadi F., Kukreja S., 2005). 3peлые формы ПТГрП могут оказать свое модулирующее воздействие на простатические эпителиальные клетки, а также участвовать в гомеостатической регуляции семенной жидкости человека (Iwamura M. et al., 1994b; Iwamura M. et al., 1994a). ПТГрП вырабатывается в эпителиальных клетках нормальной простаты (Cramer S. et al., 1996), из которых возможно развитие рака простаты. 


\subsection{2. Существующие факты и представдения о взаимосвязи паратгормон-родственного протеина и рака предстательной железы}

В данном разделе главы представлена информация об участии паратгормон-родственном белка в патофизиологических и патобиохимических процессах, связанных с развитием онкопатологии предстательной железы и по основным аспектам взаимосвязи ПТГрП и рака предстательной железы (РПЖ). Основное внимание уделено влиянию паратгормон-родственного белка на эффекты, которые являются ключевыми в развитии рака в естественных условиях, участию паратгормон-родственного белка в модулировании фенотипических проявлений онкотрансформации ткани простаты, а также в формировании локальных и организменных реакций в ответ на лечение рака предстательной железы.

Уникальные особенности ПТГрП привлекли внимание многих исследователей к проблеме взаимосвязи этого белка и рака предстательной железы. Содержание ПТГрП в крови возрастает при раке простаты. По данным многих исследователей высокий уровень ПТГрП связан с прогрессированием онкологических заболеваний и повышенным риском скелетных событий (Kremer R., Li J. et al., 2011). Среди факторов, ответственных за развитие рака простаты все большее значение отводится ПТГрП, который впервые был обнаружен в качестве этиопатогенетического компонента онкоиндуцированной злокачественной гиперкальциемии (Suva L.J. et al., 1987; Boras-Granic K., Wysolmerski J.J., 2012), а позже был также обозначен как фактор, ответственный за регуляцию многих клеточных функций, критически важных для роста опухоли, ангиогенеза и метастазирования (Rahim F. et al., 2014; Guntur A.R. et al., 2015).

ПТГрП был иммуногистохимически идентифицирован в ткани рака простаты у пациентов с клинически локализованным заболеванием (Iwamura M. et al., 1993) и обнаруживался в более высоких уровнях в интраэпителиальной неоплазии простаты, чем в нормальном эпителии простаты (Iwamura M. et al., 1995), а также находился в более высоких уровнях в раке простаты, чем при доброкачественной гиперплазии (Asadi F. et al., 1996). Показано, что образование 
ПТГрП в клетках РПЖ существенно выше в клетках с низкодифференцированным раком по сравнению с высокодифференцированной опухолью простаты (Iwamura M. et al., 1995). ПТГрП является одним из продуктов, секретируемых простатическими нейтроэндокринными клетками, а его повышенная экспрессия в предстательной железе человека является проявлением регуляции ненормальных ростовых процессов.

ПТГрП секретируется клетками трех изученных злокачественных простатических клеточных линий человека (PC3, DU-145 и LNCaP). Самый высокий уровень ПТГрП выявлен в РС3 линии, которая образует костные метастазы. Увеличение пролиферации клеток РС3 и DU-145 может быть вызвано добавлением синтетического ПТГрП к клеточным культурам, что рассматривается как доказательство того, что ПТГрП может быть существенным фактором в аутокринной регуляции роста опухоли простаты (Iwamura M. et al., 1994). ПТГрП в естественных условиях усиливает рост рака простаты, повышает жизнеспособность клеток опухоли, их миграцию и метастазирование, активируя экспрессию проинвазивного интегрина аб $\beta 4$ с использованием транскрипционных путей и на посттрансляционном уровне (Bhatia V. et al., 2013). ПТГрП ингибирует активность каспаз 3 и 7, что ослабляет протеолиз пептида этими энзимами и уменьшает эффект торможения каспазами апоптоза и миграции опухолевых клеток. Это свидетельствует о взаимосвязи между ПТГрП, интегрином аб $\beta 4$, активностью каспаз и выживаемостью и миграцией клеток рака простаты (Bhatia V. et al., 2013). Установлено, что ПТГрП может способствовать процессу эпителиально-мезенхимальной трансформации, активизируя инвазию и рост рака простаты не только путем содействия резорбции костной ткани, но и выступая в качестве важного фенотипического регулятора степени агрессивности опухоли (Ongkeko W.M. et al., 2014). Сверхэкспрессия интерлейкина-6, а также ПТГрП вовлечены в прогрессирование рака простаты и костных метастазов. Установлено, что ПТГрП может быть посредником эффектов интерлейкина-6 на остеобластные клетки. Интерлейкин-6 индуцирует секрецию ПТГрП в клетках рака простаты и участвует во взаимодействии опухоли с мезенхимальными стволовыми клетками 
костного мозга, что является существенным фактором в прогрессировании РПЖ (Asadi F., 2014). Доказательство того, что ПТГрП является не только критическим медиатором опухолевой прогрессии при раке предстательной железы, но и промотором эпителиальномезенхимальной трансформации предполагает еще более значимую роль пептида в прогрессировании рака, чем считалось ранее, так как способность регулировать эпителиально-мезенхимальную трансформацию подразумевает потенциальную возможность регулировать инвазию, метастазирование, адгезивность клеток опухоли, ангиогенез, а также свойства стволовых клеток при раке простаты (Yilmaz M., Christofor G., 2009; Asadi F. et al., 1996; Mani S.A. et al., 2008; Kang Y., Massagué J., 2004; Ardura J.A. et al., 2010).

В экспериментах на модели рака простаты человека мышам вводили клетки РПЖ, трансфицированные различными изоформами ПТГрП в сравнении с опытами, в которых вводили нетрансфицированные клетки опухоли. Внутрикостное введение трасфицированных клеток приводило к бо́льшей прогрессии опухоли, что рассматривается как прямое экспериментальное доказательство того, что экспрессия ПТГрП способствует прогрессированию метастазов рака простаты (Deftos L.J. et al., 2005). В экспериментальном исследовании показано, что 1,25-дигидровитамин Д3 подавляет мРНК ПТГрП и уровни белка в клетках рака простаты человека. Это рассматривается как механизм ингибирования экспрессии ПТГрП в ткани РПЖ и как потенциальная возможность направленной нейтрализации участия ПТГрП в развитии и прогрессировании опухоли и тенденции к ее метастазированию. Продемонстрировано регулирование экспрессии гена ПТГрП с помощью витамина D с использованием клеточной линии рака простаты человека РС-3 в качестве модельной системы. Витамин D оказывает защитное действие против рака предстательной железы через его антипролиферативное действие. Установлено, что мРНК ПТГрП и секретируемые уровни белка регулируются 1,25-дигидроксивитамином D (3) с помощью транскрипционного механизма. Показано, что экспрессия гена ПТГрП повышается также посредством механизма транскрипции эпидермальным фактором роста (EGF), который обычно секретируется клетками рака предстательной 
железы. 1,25 (OH) (2) D (3) отменил EGF-индуцированную регуляцию ПТГрП как на уровне мРНК, так и на уровне белка. Поскольку ПТГрП усиливает рост клеток рака предстательной железы, это исследование демонстрирует важность поддержания адекватных уровней 1,25 (ОH) (2) D (3) (Tovar Sepulveda V.A., Falzon M., 2002).

Было показано, что по мере прогрессирования РПЖ экспрессия ПТГрП увеличивается при одновременном уменьшении экспрессии белка, ингибирующего дифференцировку остеобластов (DKK-1). Известно, что DKK-1 является ключевым регулятором костного ремоделирования как в физиологических условиях, так и при патологических состояниях, и, что блокирование этого фактора может ингибировать как стимуляцию остеокластогенеза так и ингибирование остеобластов. Эти факты явились основанием для гипотезы о том, что ПТГрП может быть негативным регулятором экспрессии DKK-1 в клетках РПЖ и это способствует активации внутриклеточного сигнального пути Wnt, регулирующего дифференцировку клеток и развитие злокачественных опухолей. Реализация эффектов взаимодействия ПТГрП и Wnt сигнальных путей происходит путем ингибирования экспрессий DKK-1 через C-jun-опосредованное торможение активации бетта-катенина промотора DKK-1 при РПЖ (Zhang H. et al., 2014).

Показано, что ПТГрП, присутствующий в повышенных количествах в микроокружении очагов рака предстательной железы, является критическим фактором сенсибилизации смежных ноцицептивных эфферентов участвующих в реализации механизмов хронической боли, связанной с онкологическим процессом (Mickle A.D. et al., 2015).

\subsubsection{1. Антиапоптозный эффект паратгормон-родственного белка при раке предстательной железы}

Установлено, что концерогенез предстательной железы характеризуется увеличением секреции ПТГрП, который вызывает антиапоптозный эффект в ткани опухоли ( Da Silva J. et al., 2009). Описан эффект угнетения экспрессии ПТГрП клетками рака простаты под влиянием аденовируса Е1А, что уменьшало выживаемость клеток вследствие сенсибилизации к апоптозу (Asadi F.K. et al., 2010). 
ПТГрП-индуцируемый антиапоптозный эффект зафиксирован в исследовании на линии клеток РПЖ человека (Bhatia V. et al., 2013).

Известно, что отделение клетки от взаимодействующего с ней матрикса может привести к гибели клетки в результате запрограммированной смерти клетки в результате утраты нормального взаимодействия с матриксом (Frisch S.M., Screaton R.A., 2001; Chiarugi P., Giannoni E., 2008). Опухолевые клетки активируются к апоптозу, когда они теряют принадлежность к их внеклеточному матриксу. Особым биологическим свойством ПТГрП является его интракринное действие, обусловленное локализацией пептида в ядре клеток. Установлено, что ядерная локализация ПТГрП играет решающую роль в регуляции экспрессии генов и, в частности, проапоптотического гена TNF, что предотвращает аноикис (специфический тип апаптоза «по умолчанию») клеток рака простаты с нарушенным взаимодействием с тканевым матриксом (Park S.I., McCauley L.K., 2012). Обход anoikis в метастатическом процессе имеет важное значение для успешной колонизации опухолевых клеток рака предстательной железы в отдаленных органах (Sakamoto S., Kyprianou N., 2010). ПТГрП-опосредованная защита клеток РПЖ от апоптоза может иметь место при воздействии различных индукторов апоптоза (например, химиотерапии).

Показано, что у пациентов с распространенным РПЖ уровни сывороточного интерлейкина-6 и ПТГрП значительно увеличены. Интерлейкин-6 вызывает в клетках РПЖ экспрессию ПТГрП и это повышает устойчивость клеток опухоли к апоптозу. Блокировка интерлейкина-6 приводит к подавлению продукции ПТГрП и активации апоптоза клеток РПЖ. Таким образом, ингибиторы интерлейкина-6 могут подавлять экспрессию ПТГрП и активировать апоптоз в клетках андрогенрезистентного РПЖ (Asadi F., 2014).

\subsubsection{2. Роль паратгормон-родственного белка в метастазировании рака предстательной железы}

ПТГрП продуцируется практически во всех типах опухолей, которые метастазируются в кости и многочисленные исследования показали корреляцию между экспрессией ПТГрП и скелетной локализации опухолей. В дополнение к функционированию в качестве 
эндокринного фактора этот плейотропный белок опосредует свои действия локально на опухолевые и стромальные клетки паракринным, аутокриннымм и интракринным механизмами. ПТГрП стал ключевым фактором скелетных осложнений, связанных с метастазированием опухолей в кости (Wright L.E., Guise T.A., 2014). Эффекты ПТГрП в костной ткани реализуются через его взаимодействие c рецептором PTH1R на остеобластах. ПТГрП также регулирует пролиферацию остеобластов, участвует в ремоделировании кости в ходе которого происходит высвобождение TGF $\beta$ и кальция. Оба эти фактора влияют на рост опухолевых клеток и способствуют продолжению проидукции ПТГрП. ПТГрП также обладает остеоанаболическими свойствами, и может быть частично ответственным за реакции остеобластического типа при раке предстательной железы (Liao J., McCauley L.K., 2006).

РПЖ остается одной из основных причин смерти мужчин от онкологических заболеваний, что во многом связано с его выраженными свойствами к метастазированию (Weilbaecher K.N. et al., 2011). Одной из основных причин заболеваемости и смертности при раке предстательной железы является метастатическая болезнь костей. РПЖ находится в уникальном положени из-за его сильной склонности к метастазированию в кости (Dougherty K.M. et al., 1999). Более 70 \% пациентов с РПЖ имеют на поздней стадии заболевания костные метастазы, что существенно снижает качество жизни (Roodman G.D., 2004; Mundy G.R., 2002). В отличие от других видов рака, первоначальное метастазирование клеток РПЖ почти строго ограничено костью и часто является единственным местом дистального распространения даже на поздних стадиях заболевания (Cheville J.C. et al., 2002). Наиболее частыми местами метастазов являются кости таза и позвоночника (Sweeney C.J. et al., 2015; Aparicio A.M. et al., 2016).

Часто метастазы в кости растут быстрее, чем первичные опухоли или другие метастатические поражения. Это объясняется взаимодействием между раком предстательной железы и костными клетками (Tzelepi V. et al., 2012; Mu P. et al., 2017) и, вероятно, отражает наличие факторов, которые либо способствуют росту клеток, либо ингибируют гибель клеток. Когда клетки опухоли предстательной 
железы проникают в скелет, происходит разрушительный цикл грубого повреждения кости и роста опухоли, после чего лечебная терапия больше не возможна, и паллиативное лечение становится единственным вариантом. Поэтому понимание механизма, с помощью которого клетки РПЖ существуют и развиваются в костной среде и разработка эффективных методов для предотвращения или лечения метастазов РПЖ в кости, имеет решающее значение для увеличения выживаемости пациентов.

Поражение скелета при РПЖ является сложным процессом, в котором костная ткань обеспечивает благоприятную среду для роста опухоли. РПЖ метастазирует в кости неслучайным образом, и многочисленные доказательства подтверждают концепцию о том, что колонизация кости опухолью является активным процессом, включающим взаимную стимуляцию между клетками РПЖ и клеточными элементами в костной матрице (Logothetis C.J., Lin S.H., 2005; Nelson W.G. et al., 2003).

Клетки рака простаты имеют склонность продуцировать молекулы, которые, как правило секретируют остеобласты, в том числе остеокальцин (Huang W.C. et al., 2005; Ou Y.C. et al., 2003), остеонектин (Thomas R. et al., 2000), остеопонтина (Carlinfante G. et al., 2003; Khodavirdi A.C. et al., 2006), костный сиалопротеин (Huang W.C. et al., 2005; Khodavirdi A.C. et al., 2006), рецепторный активатор ядерного фактора-кВ-лиганда и остеопротегерин (Roato I. et al., 2005). Это явление, называемое остеомимичностью, было впервые описано Koeneman K.S. et al. (1999), который предположил, что оно способствует преимущественному росту клеток рака предстательной железы в кости.

Общепризнанно, что метастазы в кости при раке предстательной железы являются архетипическим примером конкретной ситуации «семени и почвы», возникающей в результате взаимодействия между опухолевыми клетками и микросредой кости (Fidler I.J., 2003). После того, как клетки РПЖ достигают кости, взаимодействие между опухолевыми клетками и резидентными клетками в костном мозге имеет важное значение для создания «плодородной» среды поддерживающей способности метастатических клеток РПЖ избежать 
апоптоза и оптимизировать их выживание (Kingsley L.A. et al., 2007; Bussard K.M. et al., 2008). Клетки рака простаты и микросреда костной ткани взаимодействуют друг с другом в процессе прогрессии скелетного метастазирования (Gleave M.E. et al., 1992; Gleave M. et al., 1991). Костные метастазы РПЖ часто растут более быстрыми темпами, чем первичная опухоль или метастазы другой локализации, что определяется наличием факторов, которые способствуют росту или ингибируют гибель клеток опухоли. Метастазы РПЖ преимущественно локализуются в регионах с высоким уровнем метаболизма костной ткани (Schneider A. et al., 2005; Roodman G.D., 2004) в богатых остеобластами зонах кости (Wang N. et al., 2014). Физический контакт между клетками рака предстательной железы и остеобластами в кости разрушает структуру кости и развивает цикл взаимно усиленного роста клетками рака предстательной железы и остеобластами. В экспериментах Kimura Y. et al. (2017) продемонстрировали, что остеобласты, которые были культивированы с клетками MDA$\mathrm{PCa}-2 \mathrm{~b}$, увеличивали количество обоих типов клеток и увеличивали экспрессию щелочной фосфатазы. Более того, в присутствии клеток рака предстательной железы остеобласты не выровнялись по коллагеновой матрице нормальным образом, а скорее демонстрировали неорганизованную структуру. Эта результирующая анизотропия костной матрицы может усилить метастазы рака предстательной железы.

Клетки РПЖ способны к высокой степени адгезии и локализации в участках костной ткани с активным ремоделированием, которое, по меньшей мере, частично, регулируется с участием ПТГрП (Mak I.W., 2013). Совместная экспрессия ПТГрП и его рецептора была установлена при первичном раке простаты и при его метастазировании в кости (Bryden A.A. et al., 2002). Сообщалось об увеличенной экспрессии рецептора ПТГрП в костных метастазах рака предстательной железы по сравнению с первичными опухолями, что указывает на потенциальную роль рецептор-опосредованных механизмов в формировании скелетных метастазов (Iddon J. et al., 2000). ПТГрП активизирует различные митогенные пути, и в том числе способствовует эпителиально-мезенхимальному переходу, в раковых стволовых клетках, что стимулирует костное 
метастазирование опухоли (Ongkeko W.M. et al., 2014). Молекулярные механизмы метастазирования РПЖ сложны, включают ряд последовательных событий и взаимосвязанных факторов. Несмотря на интенсивные исследования, молекулярные механизмы, лежащие в основе метастазирования, все еще остаются недостаточно изученными (Clarke N,W., 2009).

Метастатическая колонизация отдаленных органов требует распространения опухолевых клеток обладающих способностями к выживанию в кровеносном русле, вторжению во внеклеточный матрикс, и адаптации к новой среде (Rahim F. et al., 2014), которые опосредованы многочисленными факторами опухолевого происхождения. В связи с этим, клетки рака простаты продуцируют многочисленные костные модулирующие цитокины, включая ПТГрП, остеопротегерин, лиганд рецептора активатора ядерного фактора-kB (RANKL), и другие (Deftos L.J. et al., 2005). RANKL и ПТГрП известны как ключевые факторы остеокластогенеза в кости, и они играют ключевую роль в метастазировании костей многих видов рака (Liao J., McCauley L.K., 2006; Keller E.T., 2002; Kitazawa S., Kitazawa R., 2002; Roodman G.D., 2001; Mundy G.R., 2007).

B метастазировании РПЖ существенная роль принадлежит балансу этих цитокинов, а также инсулиноподобного фактора роста, макрофагального колониестимулирующего фактора и ряда других биологически активных молекул. Сдвиг их равновесия в определенной мере может быть связан с изменением секреции эпителиоцитами простаты сериновой протеазы - простатического специфического антигена. Этот энзим может осуществлять протеолиз ПТГрП, а также расщеплять инсулиноподобный связывающий белок, что приводит к повышению уровня инсулиноподобного фактора роста-1 (Iwamura M. et al., 1996; Cohen P. et al., 1994). В экспериментах с использованием линии клеток рака простаты PC3 показано, что ПТГрП способствует выживанию клеток рака ПЖ путем активации сигнализации инсулиноподобного фактора роста (IGF-I). Селективный ингибитор IGF-I почти полностью блокировал выживание клеток рака простаты РС3 в присутствии доцетаксела (Da Silva J.O. et al., 2013). 
Физические факторы внутри кости, такие как гипоксия, низкий уровень $\mathrm{pH}$ и внеклеточный $\mathrm{Ca} 2+$, активируют сигнальные пути в клетках рака предстательной железы, что приводит к дополнительному высвобождению факторов, которые на животных моделях, повышают выживаемость и рост в кости (Kingsley L.A. et al., 2007). Более того, эти факторы активируют экспрессию стимулирующих факторов остеобластов клетками рака предстательной железы, включая фактор роста эндотелия сосудов (VEGF), тромбоцитарный фактор роста, костный морфогенный белок-2, инсулиноподобный фактор роста-1 и эндотелин-1 (Wan X. et al., 2014; Logothetis C.J., Lin S-H., 2005; Fizazi K. et al., 2003). Значение микросреды костной ткани в регионах скелета, имеющих метастазы рака простаты, становится все более очевидным, поскольку данных, свидетельствующих о существовании значительных изменений нормального ремоделирования кости у больных РПЖ становится все больше. В норме процессы формирования костной ткани остеобластами и резорбции старых костных структур остеокластами взаимосвязаны во времени и в пространстве последовательностью событий, определяющих процесс ремоделирования костной ткани. При наличии в костных структурах метастазов РПЖ в зоне костной ткани, примыкающей к очагу неопластического процесса, нарушается нормальная регуляция процессов образования костной ткани и ее резорбции (Zafeirakis A., 2010).

Для того, чтобы создать пространство для своего роста, клетки РПЖ стимулируют резорбцию костной ткани остеокластами. Активация передачи сигналов NF-кB повышает экспрессию остеолитических факторов (таких как RANKL, ПТГрП) в клетках РПЖ. Повышенный уровень этих факторов приводит к прямому или косвенному воздействию на дифференцировку остеокластов, чтобы способствовать остеокластогенезу и резорбции кости. RANKL реагирует на сигнализацию NF-кB в остеокласте путем прямого связывания с его рецептором RANK, для стимуляции дифференциации остеокластов, в то время как ПТГрП регулирует RANKL в остеобластах. Увеличение RANKL будет способствовать дальнейшему развитию остеокластогенеза путем содействия дифференциации остеокластов. Таким 
образом, остеокластическая резорбция кости, вызванная остеолитическими факторами, полученными из раковых клеток, обеспечивает достаточную микросреду для выживания и роста клеток РПЖ как при остеолитическом, так и остеобластном вариантах формирования костного метастаза (Jin R. et al., 2013).

Цитокин RANKL является одним из ключевых активаторов остеокластов, в то время как остеопротегерин (OPG) представляет собой рецептор, конкурирующий с RANK за RANKL, и поэтому является ингибитором остеокластогенеза. RANK/RANKL/OPG сигнальный путь является важнейшим регуляторным механизмом определяющим дифференцировку и активацию остеокластов в процессе ремоделирования костной ткани как в физиологических условиях так и при патологических процессах ассоциированных с опухолевым ростом и развитием метастазов (Baud'huin M. et al., 2007), включая метастазы в кости РПЖ (Theoleyre S. et al., 2004); Hofbauer L.C. et al., 2001).

Известно, что в процессе дифференциации остеокластов важную функцию выполняет ПТГрП. Помимо увеличения экспрессии RANKL в остеобласте, ПТГрП также регулирует пролиферацию и дифференцировку остеобластов в зависимости от времени и дозы (Liao J. et al., 2008; Hildreth B.E. III et al., 2010). Установлено, что активация универсального фактора транскрипции NF-kB (RANKL), контролирующего апоптоз и клеточный цикл, коррелирует с прогрессированием рака простаты и способствует метастазированию опухоли, влияя на миграцию клеток опухоли и ангиогенез. Посредством косвенных воздействий ПТГрП поддерживает остеокластогенез путем регуляции RANKL в остеобластах (Liao J., McCauley L.K., 2006). Повышенная экспрессия ПТГрП, индуцированная активацией передачи сигналов NF-кB в клетках РПЖ, может способствовать индуцированию дифференциации остеокластов, тем самым обеспечивая достаточные микроэкологические сигналы (то есть, повышенную растворимость факторов роста, связанных с костной матрицей), чтобы способствовать прикреплению и росту в кости клеток РПЖ. Активация передачи сигналов RANKL увеличивает экспрессию генов, связанных с остеокластогенезом, в клетках РПЖ. Клетки РПЖ, 
способные расти в кости, имеют более высокую активность NF-кB и активируют передачу сигналов RANKL, которые регулируют связанные с остеокластогенезом гены в клетках РПЖ, потенциально усиливая их способность прикрепляться и расти в костой микросреде. Активация передачи сигналов NF-кB в клетках РПЖ увеличивает дифференцировку остеокластов, которая обеспечивает достаточную микросреду, чтобы обеспечить выживаемость, рост и патологическое ремоделирование костной ткани при формировании костного метастаза. Инактивация NF-кB сигнализации ингибирует образование и рост в костной среде как остеолитических, так и остеобластных/ остеокластических смешанных опухолей РПЖ (Jin R. et al., 2013).

Показано, что клетки РПЖ продуцируютют несколько факторов, которые регулируют остеокластогенез, включая ПТГрП, макрофагальный колониестимулирующий фактор, члены суперсемейства трансформирующего фактора роста $\beta$ и активатор плазминогена урокиназного типа (uPA-плазмин), что приводит к активации матричных металлопротеиназ, в частности ММР-2 и ММР-9, а также интерлейкина-1 и интерлейкина-6 (Msaouel P. et al., 2008). Установлено, что повышение регуляции остеокластогенеза в микроокружении кости является необходимым предварительным условием для способности раковых клеток успешно колонизировать кости как при остеолитическом, так и при остеобластном костном метастазе (Mundy G.R., 2002; Roodman G.D., 2004). Хотя показано, что многие факторы, секретируемые клетками РПЖ, регулируют остеокластогенез и настоятельно указывают на важную роль остеокластов в успешном формировании метастазов РПЖ в кости, выявление первичного пути, который регулирует экспрессию остеокластогенного гена ответственного за способность клеток РПЖ прикрепляться и расти в костной среде остается неясной.

Остеопротегерин уменьшает онкоиндуцированное разрушение кости. Было предположено, что OPG, вырабатываемый клетками костного метастаза РПЖ, вызывает локальное снижение уровня RANKL, формируя более крутой градиент RANKL от опухоли к костной ткани, что приводит к более быстрой резорбции и росту опухолей. Эта гипотеза была проверена с помощью математической 
модели на основе системы нелинейных дифференциальных уравнений, описывающих пространственную динамику OPG, RANKL, ПТГрП, остеокластов, массы опухоли и костной массы. Показано, что экспрессия опухолью ПТГрП, индуцирующего RANKL, имеет важное значение для правильной ориентации градиента RANKL. Мета-анализ продукции OPG, RANKL и ПТГрП в клетках нормальный простаты, клетках рака железы и в ткани ее метастазов продемонстрировал увеличение экспрессии OPG, но не RANKL, в метастазах рака предстательной железы, а также положительную корреляцию между OPG и ПТГрП в метастазах рака предстательной железы (Ryser M.D. et al., 2012).

Скелетные метастазы рака простаты характеризуются как увеличением скорости резорбции кости, так и интенсивности формирования костной ткани взамен разрушенной. Интенсивный характер костного метаболизма с избыточной резорбцией костной ткани является архетипической чертой большинства, если не всех, костных метастазов (Roodman G.D., 2004). Известно, что костные метастазы РПЖ отличаются от костных метастазов других видов рака выраженной минерализацией ткани опухоли. Механизмы этого до настоящего времени недостаточно понятны и это обуславливает их активное изучение. Предполагается, что избыточная минерализация ткани костных метастазов связана с анаболическими эффектами прерывистого воздействия ПТГрП.

В отличие от метастазов при раке легких или молочной железы, которым присущи остеолитические повреждения, костные метастазы при РПЖ является преимущественно бластными, хотя они также содержат остеорезорбтивный компонент (Morris M.J., Scher H.I., 2003). Успешная колонизация кости клетками РПЖ требует как остеолитических, так и остеобластических процессов. Это происходит частично из-за того, что клетки РПЖ способны продуцировать факторы роста, которые могут влиять как на остеобласты, так и на остеокласты, что приводит к образованию остеобластических костей и чрезмерной резорбции кости (Mundy G.R., 2002); Roodman G.D., 2004). В то время как роль остеобластов в метастазировании РПЖ хорошо известна, некоторые результаты указывают на важную роль функции 
остеокластов при успешном формировании костных метастазов (Inoue H. et al., 2005; Mori K. et al., 2007; Whang P.G. et al., 2005; Zhang J. et al., 2003; Zhang J. et al., 2001). Когда клетки РПЖ первоначально колонизируют кость, считается, что они сначала вызывают остеокластогенез (Yonou H. et al., 2004) и последующую резорбцию кости. Гистоморфометрические данные свидетельствуют о том, что остеобластические метастазы формируются в трабекулярной кости в местах предыдущей резорбции остеокластов и такая резорбция необходима для последующего образования остеобластической кости (Bradley D.A. et al., 2007). Эти данные свидетельствуют о том, что РПЖ индуцирует формирование кости путем общего увеличения ремоделирования кости. Кроме того, остеокластическая резорбция кости способствует большинству скелетных осложнений или связанных с скелетом событий (таких как перелом и боль) у пациентов с метастазами в кости. Кроме того, остеокластическая резорбция кости также способствует образованию опухолей в скелете. Поэтому предполагается, что остеокластогенез, индуцированный клетками РПЖ, является ранним событием метастазирования костей и является их необходимым предварительным условием. При РПЖ в значительной части наблюдений рентгенологически фиксируется склерозирование участков пораженной кости, формирующееся на фоне относительного превалирования процессов остеогенеза над процессами костной резорбции (Seibel M.J., 2005). Остеобластные метастазы при РПЖ происходят на участках предшествующей остеорезорбции остеокластами и характеризуются слабой, плохо организованной структурой кости, способствующей возникновению переломов различных костных элементов скелета, которые нередко обусловлены снижением минерализации костной ткани на фоне андрогендепривационной терапии (Deftos L.J. et al., 2005; Rabbani S.A. et al., 1999; Preston D.M. et al., 2002).

Продукция ПТГрП коррелирует с прогрессированием костных метастазов РПЖ, что связанно с влиянием этого белка на микроокружение метастазов и, в том числе, на остеобласты. При введении под кожу бестимусным мышам выскоэкспрессивных клеток рака простаты наблюдали образование опухолей бо́льших размеров 
по сравнению с размерами опухолей, сформировавшихся у мышей, которым вводили клетки РПЖ с меньшей способностью к экспрессии ПТГрП. Введение ПТГрП в костную ткань совместно с опухолевым имплантом вызвало значительное увеличение костной массы, прилегающей к очагам опухоли с гиперэкспрессией ПТГрП (Liao J. et al., 2008).

Этими же исследователями установлено, что ПТГрП вызывает усиленную пролиферацию стромальных клеток костного мозга и раннюю дифференциацию остеобластов. ПТГрП оказывал проангиогенный эффект косвенно, поскольку ангиогенез усиливался только в присутствии стромальных клеток костного мозга. Полученные данные позволили сделать вывод, что ПТГрП - ключевой посредник взаимодействия между клетками костных метастазов РПЖ, клеточными элементами собственно костной ткани и пулом сигнальных биомолекул различной природы (Liao J. et al., 2008).

В иммуногистохимических исследованиях экспрессии ПТГрП в биоптатах ткани костных метастазов у больных РПЖ, не получавших лечения, установлена разная степень выраженности продукции ПТГрП в разных образцах, не связанная со степенью дифференциации клеток опухоли (Bryden A.A. et al., 2002). Известно, что ПТГрП играет важную роль в молекулярных механизмах костного местазирования рака предстательной железы (Clarke N,W. et al., 2009). ПТГрП может активировать локальный остеолизис в участках кости, прилегающих к костным метастазам, что создает благоприятные условия для их развития и таким образом ПТГрП участвует в аутокринной регуляции роста опухоли. Наиболее выражена взаимосвязь инвазивного фенотипа опухоли и развития костного метастазирования с присутствием изоформы ПТГрП (1-139). ПТГрП является эффектором ростового фактора (TGF- $\beta 1)$, участвующеего в развитии и прогрессировании остеолитических костных метастазов. Этот ростовой фактор, проникая в костную ткань, индуцирует образование ПТГрП в опухолевых клетках. Затем этот белок стимулирует разорбцию костной ткани, что повышает потенциал развития костных метастазов.

Установлено, что в клетках РПЖ и в ткани костных метастазов имеет место усиленная экспрессия конституитивно активированной рецепторной тирозинкиназы DDR2, участвующей в регуляции 
клеточной дифференцировки, ремоделировании внеклеточного матрикса, клеточной миграции и дифференциации, что способствует активации инвазии клеток РПЖ. Сверхэкспрессия DDR2 в клетках РПЖ приводит к заметному ускорению дифференциации остеокластов и активации резорбции костной ткани, в то время как нокдаун DDR2 вызвал вызывал противоположные эффекты. Доказано в эксперименах на животных, что DDR2 способствует остеолитическому метастазированию регулируя экспрессию,секрецию и активацию промотора ПТГрП посредством модулирования фактора транскрипции RUNX2. Таким образом, DDR2 участвует в TGF- $\beta$-опосредованной активации остеокластов и резорбции костной ткани и играет существенную роль в метастазировании рака простаты (Yan Z. et al., 2014). ПТГрП участвует в различных сложных путях внутриклеточной и трансмембранный передачи сигналов в опухоли (Alokail M.S., 2007). ПТГрП стимулирует остеокластопосредованную резорбцию кости. Матричные металлопротеиназы (ММР-2,-3,-7,-9) могут осуществлять процессинг ПТГрП 1-36 на отдельные пептиды (ПТГрП 1-17; ПТГрП 18-26 и ПТГрП 27-36). ММР-индуцированные пептиды обладают разными биологическими свойствами и влиянием на остеобласты и остеокласты. Установлено выраженное влияние ПТГрП 1-17 и ПТГрП 1-36 на стимулирование дифференцировки остеобластов invitro. Однако in vivo ПТГрП 1-36 индуцировал четкий остеолитический эффект, который не наблюдался у ПТГрП 1-17. Эти данные позволили полагать, что ММР играют существенную роль в регуляции остеолитически-остеогенной реакции при метастатическом РПЖ (Frieling J.S. et al., 2015).

\subsubsection{3. Паратгормон-родственный белок и развитие андрогенрезистентности рака предстательной железы}

Рецидивы РПЖ после терапевтического лечения, как правило, связаны с развитием андрогенрезистентности опухолевых клеток и повышением их устойчивости к апоптозу и химиотерапевтическим воздействиям. Фармпрепараты, нацеленные на рецептор андрогенов, изначально эффективны, но большинство опухолей в конечном итоге становятся андрогенрезистентными. Mu et al. (2017) обнаружили, 
что клетки рака предстательной железы избегают эффектов андрогендепривационной терапии через изменение идентичности линии. Функциональная потеря опухолевых супрессоров ТP53 и RB1 способствовала сдвигу от эпителиальных клеток,зависимых от рецепторов андрогенов к независимым от таких рецепторов базальноподобным клеткам. В смежной работе Ku et al. (2017) обнаружили, что метастазы рака предстательной железы, переключение линий и лекарственная устойчивость были обусловлены комбинированной потерей тех же опухолевых супрессоров и сопровождались повышенной экспрессией эпигенетического регулятора Ezh2. Ингибиторы Ezh2 отменили переключение линии и восстановили чувствительность к андрогендепривацирнной терапии в экспериментальных моделях. Несколько механизмов связаны с появлением резистентности к лечению, включая агрессивные варианты рака предстательной железы, которые возникают в результате мутаций в нескольких генах супрессоров опухолей (Aparicio A.M. et al., 2016; Tzelepi V. et al., 2012; Grasso C.S. et al., 2012). Кроме того, истощение андрогенов вызывает гены, участвующие в эпителиально-мезенхимальном переходе, который играет роль в прогрессировании рака и метастазировании (Logothetis C.J. et al., 2013). Существующие данные литературы свидетельствуют о ключевой роли сигнального пути NF-кB в контроле за инициированием и прогрессированием рака человека (Karin M., 2006; Inoue J. et al., 2007; Pacifico F., Leonardi A., 2006). Переизбыток NF-кB в ядре клеток РПЖ, по-видимому, коррелирует с хеморезистентностью РПЖ, поздней стадией, рецидивом ПСА и метастатическим распространением опухоли (Lessard L. et al., 2005; Domingo-Domenech J. et al., 2005, 2006; Ross J.S. et al., 2004; 27 Setlur S.R. et al., 2007). Сообщалось, что активация передачи сигналов NF-кB способствует развитию андрогенрезистентнго РПЖ (Jin R.J. et al., 2008). В культуре клеток рака простаты ПТГрП при низких уровнях андрогенов способствует росту андрогензависимых клеток опухоли. Показано, что клетки нейроэндокринного РПЖ через экспрессию продукции ПТГрП могут влиять на сигнальный путь p38/MАРК/hsp27 вызывая в соседних клетках опухоли увеличение активности рецепторов андрогенов, что опосредует повышение резистентности опухоли к химиотерапии доцетакселом (Cui Y. et al., 2016). 
Перекрестные помехи между опухолевыми клетками и остеобластами, которые приводят к росту метастазов, облегчаются растворимыми факторами и физическим контактом между разными типами клеток (Kimura Y. et al., 2017; Kingsley L.A. et al., 2007). Взаимодействие между эпителием и стромальными клетками при раке предстательной железы может объяснять развитие резистентности и уникальные закономерности распространения опухоли. Недавние экспериментальные результаты показали, что подмножество видов рака, ассоциировалось с конкретными профилями экспрессии генов, включая антиапоптотические гены и те, которые способствуют распространению опухоли (Eiro N. et al., 2017; Navone N.M. et al., 2000).

ПТГрП индуцирует развитие резистентности к химиотерапии ингибируя апоптоз посредством угнетения продукции проапоптических факторов, включая Вах и PUMA при одновременной активации секреции противоапоптотичеких факторов Bcl-2 и $\mathrm{Bcl}-\mathrm{XL}$ (Gagiannis S. et al., 2009). Показано, что повышенная продукция интерлейкина-6, связанная с увеличенным образованием ПТГрП, существенно активирует прогрессирование РПЖ и образование костных метастазов опухоли (Asadi F. et al., 2014). Взаимодействие между клетками костного мозга имеет решающее значение в развитии андрогенрезистентности и костного метастазирования. Сывороточный уровень интерлейкина-6 существенно повышен у больных с метастатическим или андрогенрезистентным РПЖ и это является плохим прогностическим признаком. Показано, что ПТГрП является медиатором интерлейкина-6 и его рецептора (IL-6 SR) во время остеогенеза. Установлено, что увеличение коэкспрессии интерлейкина-6 и ПТГрП является надежным маркером диагностики биохимического рецидива РПЖ (Asadi F. et al., 2014).

В отличие от многих других опухолей, метастазы в кости гормонрезистентного рака предстательной железы фенотипически остеобластные, а не остеолитические. Причастны как аутокринные, так и паракринные факторы среди различных типов клеток, создавая порочный круг, который стимулирует метастатический рост (Dayyani F. et al., 2011). Матричные металлопротеиназы, хемокиновый рецептор-4, фактор роста эндотелия сосудов и фактор роста кортикальной 
ткани облегчают выживание опухолевых клеток в микроокружении кости. Факторы стимулирования остеокластов, такие как ПТГрП, трансформирующий фактор роста- $\beta$ и IL-11, также могут быть высвобождены, стимулируя костные клетки и вызывая дополнительные факторы, способствующие росту рака предстательной железы (Kingsley L.A. et al., 2007; Fournier P.G.J. et al., 2015).

Описан новый механизм обеспечения пролиферативных возможностей клеток рака простаты, индуцируемый ПТГрП ( Da Silva J. et al., 2009). Показано, что во время формирования андрогенрезистентного РПЖ клетки рака простаты продолжают продуцировать рецептор анрогенов и это свидетельствует о том, что рецептор андрогенов является критически важным фактором для пролиферации клеток рака простаты. Экспрессия рецептора андрогенов играет важную роль в развитии гормонрефрактерности РПЖ (Scher H.I., Sawyers C.L., 2005; Zegarra-Moro O.L. et al., 2002). Увеличение пула рецепторов андрогенов является необходимым и достаточным фактором, чтобы индуцировать трансформацию гормоночувствительных клеток опухоли в гормонрезистентные (Chen C.D. et al., 2004). Увеличение андрогенной рецепции обеспечивает андрогенную сигнализацию в условиях низкого содержания лиганда. Показано, что увеличение концентрации рецепторов андрогенов в клетках рака простаты способствует росту и выживанию опухоли простаты при низких уровнях андрогенов (Chen C.D. et al., 2004). Общей чертой наиболее агрессивных форм РПЖ является увеличение популяции в ткани простаты клеток с нейроэндокринными характеристиками, которые продуцируют паракринные факторы, обеспечивающие новый механизм регуляции андрогенных рецепторов на поздних стадиях заболевания. Нейроэндокринные клетки наиболее распространены в ткани гормонрезистентных форм РПЖ, в которых они обнаружены в 30-100\% наблюдений (Hirano D. et al., 2004; Jiborn T. et al., 1998).

Некоторые виды рака уклоняются от целенаправленной терапии с помощью механизма, известного как пластичность линии, при котором опухолевые клетки приобретают фенотипические характеристики клеточной линии, выживание которых больше не зависит 
от лекарственной мишени. Mu P. et al. (2017) использовали in vitro и in vivo модели рака предстательной железы человека, чтобы показать, что эти опухоли могут вызывать резистентность к антиандрогенному лекарственному препарату энзалутамиду фенотипическим сдвигом от эпителиальных клеток зависимых от андрогенных рецепторов к базальноподобным клеткам независимых от рецептора андрогенов. Эта пластичность линии связана с потерей функции генаТР53, кодирующего белок р53, который является транскрипционным фактором, регулирующим клеточный цикл и выполняющим функцию супрессора образования злокачественных опухолей, а также белка RB1 - супрессора опухоли при некоторых тяжелых формах рака одной из функций которог является предотвращение прогрессии чрезмерного роста клеток путём ингибирования клеточного цикла. Пластичность линии опосредуется повышенной экспрессией фактора транскрипции SOX2 и может быть отменена путем восстановления функций ТР53 и RB1 или путем ингибирования продукции SOX2. Таким образом, мутации в генах супрессоров опухолей могут создавать состояние повышенной клеточной пластичности, которое способствует процессу развития андрогенрезистентности через переключение линий.

Андрогенрезистентный рак предстательной железы, может демонстрировать вариант гистологии с измененной экспрессией маркера линии, предполагая, что пластичность линии способствует развитию резистентности к фармпрепаратам. Не совсем понятны механизмы, лежащие в основе пластичности рака простаты. Пластичность линии можетстимулировать прогрессирование рака предстательной железы, позволяя адаптироваться к избирательному давлению, наблюдаемому во время метастазирования и анлрогендепривационной терапии. Ku S.Y. et al. (2017) в экспериментах с использованием модели рака предстательной железы мыши продемонстрировали, что потеря RB1 облегчает пластичность линии и метастазирование аденокарциномы предстательной железы, инициированную мутацией гена PTEN,который часто бывает мутирован при различных типах злокачественных опухолей. Дополнительная потеря ТР53 вызывает резистентность к антиандрогенной терапии. 
Профилирование экспрессии генов показывает, что опухоли мышей напоминают нейроэндокринные варианты рака предстательной железы человека; как мыши, так и опухоли человека, которые демонстрируют повышенную экспрессию эпигенетических факторов перепрограммирования, таких как Ezh2 и Sox2. RB1 и TP53 подавляют эпигенетические факторы перепрограммирования, такие как Ezh2 и Sox2, которые важны для генерации индуцированных плюрипотентных стволовых клеток. Представленные данные подтверждают, что потери RB1 и TP53 при раке предстательной железы депрессируют эти же факторы, создавая эпигенетическую среду, подобную стволовым клеткам, разрешающую пластичность линии. Таким образом RB1и TP53 взаимодействуют для подавления пластичности рака простаты, метастазов и антиандрогенной резистентности. Клинически значимые ингибиторы Ezh2 восстанавливают экспрессию рецептора андрогена и чувствительность к антиандрогенной терапии. Эпигенетическая модуляция может изменить или задержать трансформацию линии, увеличивая продолжительность клинически выгодных ответов на андрогендепривационную терапию.

Низкая пролиферативная активность нейроэндокринных клеток повышает их резистентность к воздействию химиотерпии, лучевой и гормональной терапии (Hvamstad T. et al., 2003). Нейроэндокринные клетки продуцируют сигнальные факторы, обеспечивающие рост и выживание окружающих опухолевых клеток, а также способствующие прогрессированию гормонрефактерных форм рака (Bonkhoff H. et al., 1991; Noordzij M.A. et al., 1996). Показано, что ПТГрП, продуцируемый нейроэндокринными клетками, сигнализацией, опосредованной через рецептор эпидермального фактора роста формирует фенотип прогрессирующего рака предстательной железы за счет повышения стабильности белковой структуры рецептора андрогенов путем ингибирования протеосомнозависимой деградации рецептора, имеющей место в физиологических условиях (Da Silva J. et al., 2009). Это обеспечивает накопление рецепторов андрогенов в клетках рака простаты, способствуя тем самым росту опухоли в условиях низкого содержания андрогенов и развитию гормонрефрактерных форм заболевания. Решающее значение для ПТГрП индуцированной регуляции 
андрогенной рецепции имеет активация рецептора эпидермального фактора роста.

В современной клинической медицине исследование ПТГрП у больных находит все большее применение для дифференциальной диагностики первичного гиперпаратиреоидизма и гиперкальциемий, связанных со злокачественными новообразованиями, а также для мониторинга эффективности печения и прогнозирования состояния больных с различными онкологическими заболеваниями и в том числе при раке предстательной железы (Otieno B.A. et al., 2016). Ведется активный поиск возможностей использования ПТГрП, а также его пептидных фрагментов в качестве мишени для специфической иммунотерапии различных видов онкопатологии, включая РПЖ (Arima Y. et al., 2005; Yao A. et al., 2005).

Результаты анализа информации, представленной в данном разделе главы, а также в предшествующих наших обзорах (Курзанов А.Н. и соавт., 2016; Медведев В.Л. и соавт., 2017) позволяют утверждать, что в настоящее время ПТГрП рассматривается как один из ключевых регуляторов физиологических и патологических процессов в предстательной железе и полагать, что результаты научных исследований этого уникального протеина будут конвертированы в медицинские технологии и фармпрепараты, которые найдут эффективное применение в таргетной терапии рака предстательной железы.

\section{2. Участие паратгормон-родственного протеина в фукционировании и онкотрансформации яичек (семенников)}

\subsection{1. Физиодогические эффекты паратгормон-родственного протеина в семенниках}

Исследователями медицинского университета Белостока с использованием иммуногистохимических методов изучена локализации ПТГрП в семенниках самцов европейского зубра и сосновой полевки. Иммунореактивность ПТГрП наблюдалась в сперматогенных клетках семенных канальцев европейского зубра и сосновой полевки, причем наиболее сильная реакция наблюдалась у сперматозоидов яичка сосновой полевки. Экспрессия ПТГрП в гладкой мускулатуре сосудов придатка и яичка выявлена у обоих видов животных, а также 
в эндотелиальных клетках придатка зубра. ПТГрП также экспрессировался в гладких мышцах эпидидимального протока у европейского бизона и сосновой полевки. Присутствие ПТГрП в эндотелии сосудов и гладких мышцах яичка и придатка яичка по мнению авторов связано с регуляцией тонуса сосудистых мышц, что влияет на кровоток в сосудах. Предполагается, что экспрессия ПТГрП зависит от ряда местных факторов, а сам этот протеин способствует пролиферации и дифференцировке сперматогенных клеток.(Czykier E., Zabel M., Surdyk-Zasada J., 2001). Представленные результаты были дополнены данными последующего исследования локализации ПТГрП в препубертатном и пубертатном семенниках европейского бизона. Иммунореактивность ПТГрП наблюдалась в зародышевых клетках яичка как у препубертатных, так и у пубертатных животных. У телят ПТГрП был обнаружен в зародышевых клетках в семенных канальцах без просвета. Реакция была сильной и регулярно распределялась в цитоплазме. У взрослых животных реакция в сперматогенных клетках бала дифференцированной. Некоторые клетки были сильно и диффузно окрашены, другие проявляли более слабую реакцию зернистого рисунка. Клетки Сертоли и клетки Лейдига были ПТГрП-отрицательными у телят и взрослых животных (Czykier E., Zabel M., Surdyk-Zasada J., 2002). В той же лаборатории выполнено сравнительное исследование (Czykier E., Zabel M., Surdyk-Zasada J., 2003) экспрессии ПТГрП в эпидидимисах взрослых европейских бизонов и 12- и 5-месячных телят. Наибольшая экспрессия ПТГрП наблюдалась у взрослых животных в мышечных клетках и эндотелии крупных сосудов, а также в мышечных клетках эпидидимального протока. У однолетних телят реакция была слабее, чем у взрослых быков, и была самой слабой у 5-месячных телят. Однако в небольших сосудах взрослых животных, в сосудистых клетках и клетках гладких мышц придатков реакция на ПТГрП была значительно более слабой у однолетних телят и отрицательной у 5-месячных телят. Аналогичная следовая реакция наблюдалась в мышечных клетках эпидидимального протока у 5 и 12-месячных телят. Настоящее исследование показало, что экспрессия ПТГрП в клетках гладких мышц сосудов и вне сосудов и в эндотелиальных клетках придатков семенников у зубров коррелирует с возрастом животного и размером органа. 


\subsection{2. Паратгормон-родственный протеин-ассоциированные новообразования в семенниках}

Ассоциация семиномы и злокачественной гиперкальциемии встречается крайне редко. Менее десяти случаев задокументировали эту исключительную связь. Во всех предыдущих отчетах ПТГрП не измерялся. Rodríguez-Gutiérrez R. et al. (2014) представили первый зарегистрированный случай злокачественной гиперкальциемии у пациента с семиномой, связанной с паранеопластической секрецией ПТГрП и 1,25-дигидроксивитамина D. В данном случае диагноз чистой семиномы был хорошо документирован. Результат гистопатологического исследования соответствовал семиноме. Уровень исходного сывороточного кальция был повышен, уровень мочевого кальция, фосфора и 25-гидроксивитамина D был в норме, паратгормон не определялся, а кальцитриол и ПТГрП были повышены. После одного курса успешной химиотерапии уровни кальция, ПТГрП и 1,25-дигидроксивитамина D вернулись к нормальным значениям.

В 2004 году был опубликован отчет о первом случае опухоли половых клеток с гиперкальциемией, вызванной биохимически подтвержденным высоким содержанием сывороточного ПТГрП и второй случай внегонадной несеминоматозной опухоли половых клеток (Sorscher S., 2004). В случае о котором сообщалось было установлено, что ПТГрП повышен, а паратгормон подавлен, как и следовало ожидать, когда ПТГрП является причиной гиперкальциемии. Названные лабораторные данные нормализовались после проведенной химиотерапии.

\section{3. Участие паратгормон-родственного протеина в фукционировании и неопластических поражениях подового чдена \\ 3.3.1. Физиологические эффекты паратгормон-родственного белка в пенисе}

В почках, мочевом пузыре, матке, а также в сердце и сосудах, механическое растяжение и эффекты вазоконстрикторов, таких как ангиотензин II или эндотелин, являются мощными регуляторами увеличения экспрессии ПТГрП (Philbrick W.M. et al., 1996; Massfelder T. et al., 1996). Активация регуляторных эффектов ПТГрП рассматривается в качестве адаптивного механизма для повышения соответствия 
сосудистой стенки просветному заполнению, системному или локальному артериальному давлению. Путем экстраполяции из вышеприведенной информации оказалось возможным предположить, что ПТГрП может быть одним из многочисленных факторов, вовлеченных в контроль тонуса гладкой мускулатуры пещеристых тел. Экспрессию, локализацию и влияние ПТГрП на кавернозное давление в половом члене крысы изучили Lang H. et al. (1999). Иммуногистохимические исследования с использованием специфических антител показали картину распределения иммунореактивности ПТГрП в основных структурно-функциональных компонентах пениса крысы, включая сосудистую сеть, кавернозные гладкие мышцы и нервы полового члена. ПТГрП был обнаружен на протяжении всего сосудистого русла пениса крысы, включая глубокую артерию полового члена, дорсальные вены, кавернозные артериолы и вены и субальбугинальное венозное сплетение, в гладкомышечных структурах кавернозных тел и трабекулярных фибробластах. Сильное иммуноокрашивание на ПТГрП было также обнаружено в пучках дорсальных нервов. ПТГрП-ммунореактивность была выявлена в спинном, кавернозном и субальбугинальном нервных пучках. Небольшие нервные пучки, показывающие иммунореактивность к ПТГрП были обнаружены рядом с кавернозными сосудами и гладкими мышцами. Авторы предположили, что ПТГрП может принадлежать к семейству нейропептидов с функциональной ролью в качестве нейромедиатора или модулятора нейротрансмиссии при эрекции полового члена крысы.

Находки иммунопозитивных структур в пенисе крысы побудили авторов к исследованию эффектов внутрикавернозных инъекций ПТГрП и способности N-концевого домена этого протеина модулировать тонус кавернозных тел в естественных условиях. Способность ПТГрП-(1-36), проявлять миорелаксантные свойства при взаимодействии с рецептором PTH1R в сосудистой, а также в экстравазальной гладкой мускулатуре хорошо изучена (Philbrick W.M. et al., 1996; Massfelder T., Helwig J.J., 1999; Schlüter K.-D., 1999). Установлено, что ПТГрП может заметно изменять эректильную реакцию на интракавернозное введение папаверина. Максимальный потенцирующий эффект был достигнут при дозе ПТГрП всего 30 пмоль при 
значении интракавернозного давления близком к значению среднего артериального давления. Чистый эффект одновременного введения папаверина и ПТГрП оказался в 3,3 раза выше, чем сумма показателей изменения интракавернозного давления, вызванного каждым препаратом по отдельности. С физиологической точки зрения полученные результаты убедительно свидетельствуют о том, что ПТГрП может участвовать в релаксации гладкой мускулатуры кавернозных тел. Точный механизм взаимодействия между папаверином и ПТГрП на интракавернозное давление в настоящее время неясен. Таким образом, иммуногистохимическая локализация ПТГрП во всех анатомических компонентах эректильного аппарата, вместе с его выраженным потенцирующим действием на папаверин-индуцированную кавернозную релаксацию позволяет предположить, что ПТГрП участвует в контроле тонуса гладкой мускулатуры кавернозных тел. Вместе эти наблюдения убедительно свидетельствуют о том, что ПТГрП может действовать как фактор аутокринной/паракринной релаксации кавернозно-сосудистой системы, способствуя модуляции внутрикавернозного давления. Точную роль ПТГрП в нормальной физиологии полового члена и его потенциальный терапевтический эффект еще предстоит установить.

\subsection{2. Паратгормон-родственный белок и рак подового чдена}

Неопластические поражения полового члена встречаются редко. На эти новообразования приходится менее 1\% всех случаев рака у мужчин (Gomella L., Grasso M., 1994; Muneer A., Sangar V., 2016). Полагают, что рак полового члена, вероятно, является наиболее распространенным среди других злокачественных заболеваний мочеполовой системы в гериатрической популяции (Griffin J., Mirza M., 2014). Плоскоклеточный рак составляет более $95 \%$ от диагносцируемых случаев рака полового члена. Клинические синдромы неметастатических системных эффектов, возникающие у пациентов со злокачественными заболеваниями (паранеопластические синдромы), часто ассоциируются с плоскоклеточный раком. Гиперкальциемия, как паранеопластическое проявление, является причиной более $20 \%$ 
осложнений, связанных с раком, и до 50 \% пациентов, у которых она присутствует, умерают в течение 30 дней с момента постановки диагноза. Гиперкальциемия, связанная со злокачественными новообразованиями органов мочеполовой системы индуцируется ПТГрП, продуцируемым раковыми клетками.

Появились доказательства ассоциации гиперкальциемии и плоскоклеточного рака полового члена. В научной литературе выявлены немногочисленные описания гиперкальциемии в сочетании с первичным раком полового члена (Glenn J.F., 1995; Dexeus F.H. et al., 1991; Videtic G.M. et al., 1997; Ayyathurai R. et al., 2007; Gandhi S.J., Rabadiya B., 2017). Отчет о случаях Glenn J.F. (1995) особенно интересен в описании гиперкальциемии при ранней стадии заболевания, предполагая логическую вероятность развития гуморальной гиперкальциемии злокачественного новообразования, связанную с продукцией ПТГрП, как и при других плоскоклеточных раковых заболеваниях (Henderson J.E. et al., 1990).

О случае прогрессирующей карциномы полового члена ассоциированного с повышенным почти в 10 раз уровнем ПТГрП в крови и одновременно с гиперкальциемией сообщили Dorfinger K. et al. (1999). Akashi T. et al. (2002) представили результаты исследований, выполненных у пациента с гистологически подтвержденным случаем плоскоклеточного рака полового члена. Иммуногистохимически установлена локализация ПТГрП в ткани рака полового члена. Лабораторные данные выявили гиперкальциемию и повышенное содержание ПТГрП в сыворотке крови.

О случае тяжелой гиперкальциемией, вторичной к эктопической секреции ПТГрП из плоскоклеточного рака полового члена сообщили Rogelio Trejo-Rosales R. et al. (2014). Лабораторные тесты выявили y данного пациента тяжелую гиперкальциемию и повышение уровня ПТГрП. Диагноз верифицирован исследованием биопсийного материала. Зафиксировано также редкое сочетание паранеопластических признаков при плоскоклеточном раке полового члена, включающем изменение психического статуса пациента наряду с гиперкальциемией и лейкоцитозом (Doraiswamy V.A. et al., 2010), которые все разрешились после удаления опухоли. 
Недавно Barcia R.E. et al. (2018) представили историю болезни пациента с прогрессирующим раком полового члена без предшествующей вирусной папилломы человека и метастазов в кости, но с тяжелой гиперкальциемией. При количественной полимеразной цепной реакции авторы наблюдали высокий уровень РНК ПТГрП в метастатической кожной ткани. Это первый зарегистрированный случай в Аргентине гиперкальциемии, вызванной ПТГрП-индуцируемым раковым новообразованием полового члена человека. Кроме того, связь ПТГрП и этого заболевания выявляемая с помощью количественной полимеразной цепной реакции позволила рассматривать эту молекулярную технику как новый инструмент для диагностики у пациентов с с раком полового члена.

\section{Дитература к главе 3}

1. Akashi T., Fuse H., Muraishi Y., et al. Parathyroid hormone related protein producing penile cancer. J Urol. 2002; 167: 249. doi.org/10.1016/ S0022-5347(05)65428-6.

2. Alokail M.S. Molecular signalling of PTHrP in tumor. In Novel Aspects of PTHrP Physiopathology; Luparello C. Ed.; Nova Science Publishers: New York, NY, USA, 2007; pp. 191-233.

3. Aparicio A.M., Shen L., Tapia E.L.N., Lu J-F., et al. Combined tumor suppressor defects characterize clinically defined aggressive variant prostate cancers. Clinical Cancer Research. 2016; 22(6): 1520-1530. doi: 10.1158/1078-0432.CCR-15-1259.

4. Ardura J.A., Rayego-Mateos S., Ramila D.et al. Parathyroid hormone-related protein promotes epithelial-mesenchymal transition // J Am Soc Nephrol 2010; 21: 237-248.

5. Arima Y., Matsueda S., Yano H. et al. Parathyroid hormone-related protein as a common target molecule in specific immunotherapy for a wide variety of tumor types // Int. J. Oncol. 2005; 27:981-988.

6. Asadi F., Faraj M., Sharifi R. et al. Enhanced expression of parathyroid hormone-related protein in prostate cancer as compared with benign prostatic hyperplasia // Human Pathology. 1996. 12(27): 1319-1323.

7. Asadi F., Kukreja S. PTHrP expression in prostate cancer // Review: Crit. Rev.Euk.Gene Exp. 2005; 15(1): 28-42. 
8. Asadi F., Swanson B., Zariffard R., Kukreja S. Increased Coexpression of Interleukin-6 and Parathyroid Hormone-related Peptide:A Potential Therapeutic Target and/or a Prognostic Marker for Prostate // Cancer. LOI for Portes IOM.July 2014.

9. Asadi F.K.; Kukreja S.C.; Boyer, B. et al. E1A oncogene expression inhibits PTHrP P3 promoter activity and sensitizes human prostate cancer cells to TNF-induced apoptosis // Int. Urol. Nephrol. 2010; 42: 971-978.

10. Ayyathurai R., Webb D.B., Susan Rowland, Stephenson T.P., Andrew J. Thomas Humoral Hypercalcemia of Penile Carcinoma. Urology 2007; 69(1): 184.e9-10. DOI: 10.1016/j.urology.2006.10.012.

11. Barcia R.E., Martín M.J., de la Hoz A.P., de Los Ángeles Juárez M., Gentili C. Case Report: Penile Squamous Cell Carcinoma Associated With Severe Hypercalcemia and High Levels of Parathyroid Hormonerelated Peptide Expressed in Metastatic Skin Tissue. Urology. 2018; 120:e11-e12. doi: 10.1016/j.urology.2018.07.019.

12. Baud'huin M., Duplomb L., RuizVelasco C. et al. Key roles of the OPG-RANK-RANKL system in bone oncology // Expert Rev Anticancer Ther 2007; 7 (2): 221-32.

13. Bhatia V., Mula R.V., Falzon M. Parathyroid hormone-related protein regulates integrin $\alpha 6$ and $\beta 4$ levels via transcriptional and posttranslational pathways // Exp Cell Res. 2013; 319(10):1419-30.

14. Bonkhoff H., Wernert N., Dhom G., Remberger K. Relation of endocrine-paracrine cells to cell proliferation in normal, hyperplastic, and neoplastic human prostate // Prostate. 1991; 19: 91-8.

15. Boras-Granic K., Wysolmerski J.J. PTHrP and breast cancer: more than hypercalcemia and bone metastases // Breast Cancer Research 2012; 14:307.

16. Bradley D.A., Hussain M., Dipaola R.S., Kantoff P. Bone directed therapies for prostate cancer. J Urol. 2007; 178: S42-S48.

17. Bryden A.A, Islam S., Freemont A.J. et al. Parathyroid hormonerelated peptide: expression in prostate cancer bone metastases // Prostate Cancer Prostatic Dis. 2002; 5(1): 59-62.

18. Bryden A.A., Hoyland J.A., Freemont A.J. et al. Parathyroid hormone related peptide and receptor expression in paired primary prostate cancer and bone metastases // British journal of cancer 2002. 86: 322-325. 
19. Burtis W.J., Wu T., Bunch C. et al. Identification of a novel 17,000-dalton parathyroid hor-mone-like adenylatecyclase-stimulating protein from a tumor associated with humoral hyper-calcemia of malignancy. J Biol Chem.1987; 262: 7151-7156.

20. Bussard K.M., Gay C.V., Mastro A.M. The bone microenvironment in metastasis; what is special about bone? Cancer Metastasis Rev. 2008 27: 41-55.

21. Carlinfante G., Vassiliou D., Svensson O., Wendel M., Heinegard D., Andersson G. Differential expression of osteopontin and bone sialoprotein in bone metastasis of breast and prostate carcinoma. Clin Exp Metastasis. 2003; 20: 437-44.

22. Chen C.D., Welsbie D.S., Tran C. et al. Molecular determinants of resistance to antiandrogen therapy. Nat Med. 2004; 10: 33-9.

23. Cheville J.C., Tindall D., Boelter C., Jenkins R., Lohse C.M., et al. Metastatic prostate carcinoma to bone: clinical and pathologic features associated with cancer-specific survival. Cancer. 2002; 95: 1028-1036.

24. Chiarugi P., Giannoni E. Anoikis: a necessary death program for anchorage-dependent cells // Biochemical pharmacology. 2008. 76(11), 1352-1364.

25. Clarke N.W., Hart C.A., Brown M.D. Molecular mechanisms of metastasis in prostate cancer // Asian Journal of Andrology. - 2009; 11: 57-67.

26. Cohen P., Peehl D.M., Graves H.C., Rosenfeld R.G. Biological effects of prostate specific antigen as an insulin-like growth factor binding protein-3 protease // J Endocrinol 1994; 142: 407-15.

27. Cramer S.D., Peehl D.M., Edgar M.G., Wong S.T., Deftos L.J., Feldman D. Parathyroid hormone-related protein (PTHrP) is an epidermal growth factor-regulated secretory product of human prostatic epithelial cells // Prostate. 1996; 29: 20-29.

28. Cui Y., Sun Y., Hu S. et al. Neuroendocrine prostate cancer (NEPCa) increased the neighboring PCachemoresistance via altering the PTHrP/p38/Hsp27/androgen receptor (AR)/p21 signals // Oncogene. $2016 \mathrm{Jul} 04$.

29. Czykier E., Zabel M., Surdyk-Zasada J. (2002). Immunolocalization of PTHrP in prepubertal and pubertal testis of European bison. Folia histochemica et cytobiologica, 40 4, 373-5. 
30. Czykier, E., Zabel, M., \& Surdyk-Zasada, J. (2001). Immunolocalization of PTHrP in the European bison and pine vole testis and epididymis. Folia histochemica et cytobiologica, 39 2, 57-61

31. Czykier, E., Zabel, M., \& Surdyk-Zasada, J. (2003). Comparison of PTHrP expression in the epididymis of juvenile and adult European bisons. Folia histochemica et cytobiologica, 41 3, 149-54.

32. Da Silva J., Gioeli D., Weber M.J., Parsons S.J. The neuroendocrine-derived peptide parathyroid hormone-related protein promotes prostate cancer cell growth by stabilizing the androgen receptor // Cancer Res. 2009; 69(18): 7402-7411.

33. Da Silva J.O., Amorino G.P., Casarez E.V. et al. Neuroendocrinederived peptides promote prostate cancer cell survival through activation of IGF-1R signaling // Prostate. 2013; 73(8): 801-12.

34. Dayyani F., Gallick G.E., Logothetis C.J., Corn P.G. Novel therapies for metastatic castrate-resistant prostate cancer. JNCI Journal of the National Cancer Institute. 2011; 103(22): 1665-1675. doi: 10.1093/jnci/djr362.

35. Deftos L.J., Barken I., Burton D.W. et al. Direct evidence that PTHrP expression promotes prostate cancer progression in bone // Biochem Biophys Res Commun 2005; 327: 468-472.

36. Dexeus F.H., Legothetis C.J., Sella A., Amato R., Kilbourn R., Fitz K., Striegel A.: Combination chemotherapy with methotrexate and cis-platinum for advanced squamous cell carcinoma of the male geni-tal tract. J Urol 146: 1284-1287, 1991.

37. Domingo-Domenech J., Mellado B., Ferrer B., Truan D., Codony-Servat J., et al. Activation of nuclear factor-kappaB in human prostate carcinogenesis and association to biochemical relapse. Br J Cancer. 2005; 93: 1285-1294.

38. Domingo-Domenech J., Oliva C., Rovira A., Codony-Servat J., Bosch M., et al. Interleukin 6, a nuclear factor-kappaB target, predicts resistance to docetaxel in hormone-independent prostate cancer and nuclear factor-kappaB inhibition by PS-1145 enhances docetaxel antitumor activity. Clin Cancer Res. 2006; 12: 5578-5586.

39. Doraiswamy V.A., Biboa J., Obafemi A., Goldschmid M. Leukocytosis and Hypercalcemia: A Rare Combination of Paraneoplastic Features in Squamous Cell Penile Cancer. Southern medical journal. 2010; 103(5): 474-476. DOI: 10.1097/SMJ.0b013e3181d7b802. 
40. Dorfinger K., Maier U., Base W. Parathyroid hormone related protein and carcinoma of the penis: paraneoplastic hypercalcemia. J Urol. 1999 May; 161(5): 1570.

41. Dougherty K.M., Blomme E.A., Koh A.J. et al. Parathyroid hormone-related protein as a growth regulator of prostate carcinoma // Cancer Res 1999; 59(23): 6015-22.

42. Eiro N., Fernandez-Gomez J., Sacristán R., Fernandez-Garcia B., et al. Stromal factors involved in human prostate cancer development, progression and castration resistance. Journal of Cancer Research and Clinical Oncology. 2017; 143(2): 351-359. doi: 10.1007/s00432-016-2284-3.

43. Fidler I.J. The pathogenesis of cancer metastasis: the 'seed and soil’ hypothesis revisited. Nature Reviews. Cancer. 2003; 3(6): 453-458. doi: $10.1038 / \mathrm{nrc1098.}$

44. Fizazi K., Yang J., Peleg S., Sikes C.R., et al. Prostate cancer cellsosteoblast interaction shifts expression of growth/survival-related genes in prostate cancer and reduces expression of osteoprotegerin in osteoblasts. Clinical Cancer Research. 2003; 9(7): 2587-2597.

45. Fournier P.G.J., Juárez P., Jiang G., Clines G.A., et al. The TGF$\mathrm{b} 2$; signaling regulator PMEPA1 suppresses prostate cancer metastases to bone. Cancer Cell. 2015; 27(6): 809-821. doi: 10.1016/j.ccell.2015.04.009.

46. Frieling J.S., Shay G., Lynch C.C. MMP processing of bone metastatic prostate cancer-derived PTHrP yields novel osteogenic peptides. [abstract]. In: Proceedings of the 106th Annual Meeting of the American Association for Cancer Research; 2015 Apr 18-22; Philadelphia (PA): AACR; Cancer Res 2015; 75 (15 Suppl):Abstract nr 2386.

47. Frisch S.M., Screaton R.A. Anoikis mechanisms // Current Opinion in Cell Biology 2001; 13 (5): 555-62.

48. Gagiannis S., Muller M., Uhlemann S. et al. Parathyroid hormone-related protein confers chemoresistance by blocking apoptosis signaling via death receptors and mitochondria// Int J Cancer. 2009;125(7):1551-7.

49. Gandhi S.J., Rabadiya B. Extensive Visceral Calcification Demonstrated on 99mTc-MDP Bone Scan in Patient with Carcinoma Penis and Hypercalcemia of Malignancy. Indian J Nucl Med. 2017; 32(2): 150-152. doi: 10.4103/0972-3919.202251. 
50. Gleave M.E., Hsieh J.T., von Eschenbach A.C., Chung L.W.K. Prostate and bone fibroblasts induce human prostate cancer growth in vivo: implications for bidirectional tumor-stromal cell interaction in prostate carcinoma growth and metastasis // J. Urol. 1992; 147: 1151-1159.

51. Gleave M., Hsieh J.T., Gao C. et al. Acceleration of human prostate cancer growth in vivo by factors produced by prostate and bone fibroblasts // Cancer Res., 1991; 51: 3753-3761.

52. Glenn J.F.: Hypercalcemia and urologic malignancies. Urol 45:139-141, 1995.

53. Gomella L., Grasso M.: Malignancies of the penis. In: Cameron R.B.: Practical Oncology. Norwalk: Appleton \& Lange, 1994, pp. 339-343.

54. Grasso C.S., Wu Y-M., Robinson D.R., Cao X., et al. The mutational landscape of lethal castration-resistant prostate cancer. Nature. 2012; 487(7406): 239-243. doi: 10.1038/nature11125.

55. Griffin J., Mirza M. Penis, Testis, Urethra, and Other Genitourinary Malignancies. 2014. DOI: 10.1007/978-1-4614-9047-0_20. Geriatric Urology (pp.325-343.

56. Guerreiro P.M, Renfro J.L, Power D.M, Canario A.V.M. The parathyroid hormone family of peptides: structure, tissue distribution, regulation, and potential functional roles in calcium and phosphate balance in fish //Am J Physiol Regul Integr Comp Physiol. 2007, 292 (2): R679-R696.

57. Guise T., Mundy G.R. Physiological and pathological roles of parathyroid hormone-related peptide // Curr Opinions Nephrol Hyperten. 1996; 5: 307-315.

58. Guntur A.R., Doucette C.R., Rosen C.J. PTHrp comes full circle in cancer biology // BoneKEy Reports (2015) 4, Article number: 621 (2015).

59. Henderson J.E., Shusik C., Kremer R., Rabbani S.A., Hendy G.N., Goltzman D.: Circulating concentrations of parathyroid hormone-like peptide in malignancy and in hyperpara-thyroidism. J BoneMiner Res 5: 1990, pp. 105-113.

60. Hildreth B.E. III, Werbeck J.L., Thudi N.K., Deng X., et al. PTHrP 1-141 and 1-86 increase in vitro bone formation. J Surg Res. 2010; 162: e9-17. 
61. Hirano D., Okada Y., Minei S. et al. Neuroendocrine differentiation in hormone refractory prostate cancer following androgen deprivation therapy // Eur Urol. 2004; 45: 586-92.

62. Hofbauer L.C., Neubauer A., Heufelder A.E. Receptor activator of nuclear factor-kappaB ligand and osteoprotegerin: potential implications for the pathogenesis and treatment of malignant bone diseases. Cancer. 2001; 92: 460-470.

63. Huang W.C., Xie Z., Konaka H., Sodek J., Zhau H.E., Chung L.W. Human osteocalcin and bone sialoprotein mediating osteomimicry of prostate cancer cells: role of cAMP-dependent protein kinase A signaling pathway. Cancer Res. 2005; 65: 2303-13.

64. Hvamstad T., Jordal A., Hekmat N. et al. Neuroendocrine serum tumour markers in hormone-resistant prostate cancer // Eur Urol. 2003; 44: 215-21.

65. Iddon J., Bundred N.J., Hoyland J. et al. Expression of parathyroid hormone-related protein and its receptor in bone metastases from prostate cancer // The Journal of pathology. 2000; 191: 170-174.

66. Inoue H., Nishimura K., Oka D., et al. Prostate cancer mediates osteoclastogenesis through two different pathways. Cancer Lett. 2005; 223: $121-128$.

67. Iwamura M. et al. Parathyroid hormone related protein: a potential autocrine growth regulator in human prostate cancer cell lines // Urology 1994; 43: 675-679.

68. Iwamura M., Abrahamsson P.A., Schoen S. et al. Immunoreactive parathyroid hormone-related protein is present in human seminal plasma and is of prostate origin // J. Androl., 1994a; 15: 410-414.

69. Iwamura M., di Sant'Agnese P.A., Wu G. et al. Immunohistochemical localization of parathyroid hormone-related protein in human prostate cancer // Cancer Research. 1993; 53: 1724-1726.

70. Iwamura M., Gershagen S., Lapets O. et al. Immunohistochemical localization of parathyroid hormone-related protein in prostatic intraepithelial neoplasia // Hum. Pathol, 1995; 26: 797-801.

71. Iwamura M., Hellman J., Cockett A.T. et al. Alteration of the hormonal bioactivity of arathyroid hormone-related protein (PTHrP) as a result of limited proteolysis by prostate-specific antigen // Urology 1996; 48: 317-25. 
72. Iwamura M., Wu G., Abrahamsson P.A. et al. Parathyroid hormone-related protein is expressed by prostatic neuroendocrine cells. Urology. 1994b; 43: 667-674.

73. Jiborn T., Bjartell A., Abrahamsson P.A. Neuroendocrine differentiation in prostatic carcinoma during hormonal treatment// Urology 1998; 51: 585-9.

74. Jin R., Sterling J.A., Edwards J.R. et al. Activation of NF-kappa B signaling promotes growth of prostate cancer cells in bone // PLoS One. 2013; 8(4): e 60983.

75. Jin R.J., Lho Y., Connelly L., Wang Y-Q., Yu X., et al. The Nuclear Factor kappa B Pathway Controls Progression of Prostate Cancer to Androgen Independent Growth. Cancer Res 2008; 68: 6762-6769.

76. Kang Y., Massagué J. Epithelial-Mesenchymal Transitions: Twist in Development and Metastasis. Cell. 2004; 118: 277-279.

77. Keller E.T. The role of osteoclastic activity in prostate cancer skeletal metastases. Drugs Today (Barc). 2002; 38: 91-102.

78. Khodavirdi A.C., Song Z., Yang S., et al. Increased expression of osteopontin contributes to the progression of prostate cancer. Cancer Res. 2006; 66: 883-8.

79. Kimura Y., Matsugaki A., Sekita A., Nakano T. Alteration of osteoblast arrangement via direct attack by cancer cells: new insights into bone metastasis. Scientific Reports. 2017; 7: 44824. doi: 10.1038/srep44824.

80. Kingsley L.A., Fournier P.G., Chirgwin J.M., Guise T.A. Molecular biology of bone metastasis. Mol Cancer Ther. 2007; 6: 2609-2617.

81. Kitazawa S., Kitazawa R. RANK ligand is a prerequisite for cancer-associated osteolytic lesions. J Pathol. 2002; 198: 228-236.

82. Kitazawa R., Kitazawa, S., Fukunishi, H. et al. J Bone Miner Metab (1994) 12 (Suppl 1): S145. https://doi.org/10.1007/BF02375693.

83. Koeneman K.S., Yeung F., Chung L.W.K. Osteomimetic properties of prostate cancer cells: a hypothesis supporting the predilection of prostate cancer metastasis and growth in the bone environment. Prostate. 1999; 39: 246-61.

84. Kremer R., Li J., Camirand A., Karaplis A.C. Parathyroid hormone related protein (PTHrP) in tumor progression // Adv Exp Med Biol. 2011; 720: 145-60. 
85. Kronenberg H.M. PTHrP and skeletal development. Ann. N.Y. Acad. Sci. 2006; 1068: 1-13.

86. Ku S.Y., Rosario S., Wang Y. et al. Rb1 and Trp53 cooperate to suppress prostate cancer lineage plasticity, metastasis, and antiandrogen resistance. Science 2017; 355(6320): 78-83.DOI: 10.1126 / science.aah4199.

87. Lang H., Endlich N., Lindner V., Endlich K., Massfelder T., Stewart A.F., Saussine C., Helwig J.J. Parathyroid hormone-related protein in rat penis: expression, localization, and effect on cavernosal pressure. Endocrinology. 1999 Sep;140(9): 4342-50.

88. Lessard L., Begin L.R., Gleave M.E., Mes-Masson A.M., Saad F. Nuclear localisation of nuclear factor-kappaB transcription factors in prostate cancer: an immunohistochemical study. Br J Cancer. 2005; 93: 1019-1023.

89. Liao J., Li X., Koh A.J., Berry J. E. et al. Tumor expressed PTHrP facilitates prostate cancer-induced osteoblastic lesions // Int J Cancer. 2008; 123(10): 2267-78.

90. Liao J., McCauley L.K. Skeletal metastasis: Established and emerging roles of parathyroid hormone related protein (PTHrP). Cancer and Metastasis Reviews. 2006; 25(4): 559-571.

91. Logothetis C.J., Gallick G.E., Maity S.N., et al. Molecular classification of prostate cancer progression: foundation for marker-driven treatment of prostate cancer. Cancer Discovery. 2013; 3(8): 849-861. doi: 10.1158/2159-8290.CD-12-0460.

92. Logothetis C.J., Lin S.H. Osteoblasts in prostate cancer metastasis to bone. Nat Rev Cancer. 2005; 5: 21-28.

93. Luparello C. Parathyroid Hormone-Related Protein (PTHrP): A Key Regulator of Life/Death Decisions by Tumor Cells with Potential Clinical Applications // Cancers. 2011; 3: 396-407.

94. Mak I.W., Turcotte R.E., Ghert M. Parathyroid hormone-related protein (PTHrP) modulates adhesion, migration and invasion in bone tumor cells. Bone. 2013; 55(1): 198-207.

95. Mani S.A., Guo W., Liao M.J. et al. The epithelial-mesenchymal transition generates cells with properties of stem cells // Cell. 2008; 133: 704-715.

96. Martin T.J. Parathyroid Hormone-Related Protein, Its Regulation of Cartilage and Bone Development, and Role in Treating Bone Diseases // Physiological Reviews, 2016; 96 (3): 831-871. 
97. Massfelder T., Helwig J.J., Stewart A.F. 1996 Parathyroid hormone-related protein as a cardiovascular regulatory peptide. Endocrinology. 1996; 137:3151-3153.

98. Massfelder T., Helwig J.J. Parathyroid hormone-related protein in cardiovascular development and blood pressure regulation. Endocrinology. 1999; 140: 1507-1510.

99. McCauley L.K., Martin T.J. Twenty-five years of PTHrP progress: From cancer hormone to multifunctional cytokine // J Bone Miner Res. 2012; 27:1231-1239.

100. Mickle A.D., Shepherd A.J., Loo L. et al. Induction of thermal and mechanical hypersensitivity by parathyroid hormone-related peptide through upregulation of TRPV1 function and trafficking // Pain 2015; 156: $1620-1636$.

101. Mori K., Le Goff B., Charrier C. et al. DU145 human prostate cancer cells express functional receptor activator of NFkappaB: new insights in the prostate cancer bone metastasis process. Bone. 2007; 40: 981-990.

102. Morris M.J., Scher H.I. Clinical Approaches to Osseous Metastases in Prostate Cancer // The Oncologist. 2003; (8): 161-173.

103. Moseley J.M., Kubota M., Diefenbach-Jagger H. et al. Parathyroid hormone-related protein purified from a human lung cancer cell line // PNAS 1987; 84: 5048-5052.

104. Msaouel P., Pissimissis N., Halapas A., Koutsilieris M. Mechanisms of bone metastasis in prostate cancer: clinical implications. Best Pract Res Clin Endocrinol Metab. 2008; 22: 341-355.

105. Mu P., Zhang Z, Benelli M, et al. SOX2 promotes lineage plasticity and antiandrogen resistance in TP53- and RB1-deficient prostate cancer. Science (New York, N.Y.) 2017; 355 (6320): 84-88.

106. Mundy G.R. Osteoporosis and inflammation. Nutr Rev. 2007; 65: S147-S151.

107. Mundy G.R. Metastasis to bone: causes, consequences and therapeutic opportunities. Nat Rev Cancer. 2002; 2:584-593.

108. Muneer A., Sangar V. (2016) Management of Locally Advanced and Metastatic Penile Cancer. In: Muneer A., Horenblas S. (eds) Textbook of Penile Cancer. Springer, Cham. doi.org/10.1007/ 978-3-319-33220-8_11. 
109. Navone N.M., Rodriguez-Vargas M.D.C., Benedict W.F., et al. TabBO: a model reflecting common molecular features of androgen-independent prostate cancer. Clinical Cancer Research. 2000; 6(3):1190-1197.

110. Nelson W.G., De Marzo A.M., Isaacs W.B. Prostate cancer. N Engl J Med. 2003; 349: 366-381.

111. Noordzij M.A., van Weerden W.M., de Ridder C.M et al.Neuroendocrine differentiation in human prostatic tumor models // Am J Pathol 1996; 149: 859-71.

112. Ongkeko W.M., Burton D., Kiang A. et al. Parathyroid Hormone Related-Protein Promotes Epithelial-to-Mesenchymal Transition in Prostate Cancer // PLoS ONE. 2014; 9(1): e85803.

113. Otieno B.A., Krause C.E., Jones A.L. et al. Cancer Diagnostics via Ultrasensitive Multiplexed Detection of Parathyroid HormoneRelated Peptides with a Microfluidic Immunoarray// Anal Chem. 2016;88(18):9269-75.

114. Ou Y.C., Chen J.T., Yang C.R., Ko J.L., Hsieh Y.S., Kao C. Expression of osteocalcin in prostate cancer before and after hormonal therapy. Anticancer Res. 2003; 23:3807-11.

115. Pacifico F., Leonardi A. NF-kappaB in solid tumors. Biochem Pharmacol. 2006; 72: 1142-1152.

116. Park S.I. McCauley L.K. Nuclear localization of parathyroid hormone-related peptide confers resistance to anoikis in prostate cancer cells // Endocr Relat Cancer, 2012; 19: 243-254.

117. Philbrick W.M., Wysolmerski J.J., Galbraith S., Holt E., Orloff J.J., Yang K.H., Vasvada R.C., Weir E.C., Broadus A.E., Stewart A.F. (1996) Defining the roles of parathyroid hormone-related protein in normal physiology. Physiol Rev. 1996; 76: 127-173.

118. Pinheiro P.L.C., Cardoso J.C.R., Gomes A.S. et al. Gene structure, transcripts and calciotropic effects of the PTH family of peptides in Xenopus and chicken // BMCEvol Biol.2010;10:373-379.

119. Preston D.M., Torréns J.I., Harding P. et al. Androgen deprivation in men with prostate cancer is associated with an increased rate of bone loss // Prostate Cancer and Prostatic Diseases. 2002; 5, 304-310.

120. Rabbani S.A., Gladu J., Harakidas P. et al. Over-production of parathyroid hormone-related peptide results in increased osteolytic 
skeletal metastasis by prostate cancer cells in vivo // Int J Cancer. 1999; 80: $257-264$.

121. Rahim F., Hajizamani S., Mortaz E. et al. Molecular Regulation of Bone Marrow Metastasis in Prostate and Breast Cancer // Bone Marrow Research. Volume 2014 (2014), Article ID 405920, 12 rages http:// dx.doi.org/10.1155/2014/405920.

122. Roato I., Grano M., Brunetti G., et al. Mechanisms of spontaneous osteoclastogenesis in cancer with bone involvement. FASEB J. 2005; 19: 228-30.

123. Rodríguez-Gutiérrez, R., Zapata-Rivera, M.A., QuintanillaFlores, D.L., Camara-Lemarroy C.R., Lavalle-Gonzalez F.J., GonzálezGonzález J.G., Villarreal-Pérez J.Z. 1,25-dihydroxyvitamin D and PTHrP mediated malignant hypercalcemia in a seminoma.BMC Endocr Disord (2014) 14: 32. https://doi.org/10.1186/1472-6823-14-32.

124. Rogelio Trejo-Rosales, Maria J. Nevarez-Barragan, Mercedes G. Rosas-Jurado, Ivan Perez-Diaz, Ana Paula Piana Bezaury. Rare association between penile squamous cell carcinoma and parathyroid related peptide (PTH-rP) secretion. Arq Bras Endocrinol Metab. 2014; 58(6): 646-9.

125. Roodman G.D. Biology of osteoclast activation in cancer. J Clin Oncol. 2001; 19: 3562-3571.

126. Roodman G.D. Mechanisms of bone metastasis // N Engl J Med. 2004; 350: 1655-1664.

127. Ross J.S., Kallakury B.V., Sheehan C.E., Fisher H.A., Kaufman R.P., et al. Expression of nuclear factor-kappa B and I kappa B alpha proteins in prostatic adenocarcinomas: correlation of nuclear factor-kappa B immunoreactivity with disease recurrence. Clin Cancer Res. 2004; 10: $2466-2472$.

128. Rouffet J., Barlet J.P. Parathyroid hormone-related peptide (PTHrP) and bone metabolism // Arch Physiol Biochem. 1995; 103: 3-13.

129. Ryser M.D., Qu Y., Komarova S.V. Osteoprotegerin in bone metastases: mathematical solution to the puzzle // PLoS Comput Biol. 2012; 8(10): e1002703.

130. Sakamoto S., Kyprianou N. Targeting anoikis resistancein prostate cancer metastasis // Molecular Aspects of Medicine. 2010; 31: 205-214. 
131. Scher H.I., Sawyers C.L. Biology of progressive, castration-resistant prostate cancer: directed therapies targeting the androgen-receptor signaling axis // J Clin Oncol 2005; 23: 8253-61.

132. Schlüter K.-D. PTH and PTHrP: similar structures but different functions. Physiology.1999; 14(6): 243-249

133. Schneider A., Kalikin L.M., Mattos A.C. et al. Bone turnover mediates preferential localization of prostate cancer in the skeleton // Endocrinology. 2005; 146: 1727-1736.

134. Seibel M.J. Clinical use of markers of bone turnover in metastatic bone disease // Nature Clinical Practice Oncology. 2005; 2, 504-517.

135. Setlur S.R., Royce T.E., Sboner A., Mosquera J.M., Demichelis.F, et al. Integrative microarray analysis of pathways dysregulated in metastatic prostate cancer. Cancer Res. 2007; 67: 10296-10303.

136. Sorscher S.: Elevated parathyroid hormone-related peptide in a patient with an extragonadal germ-cell tumour and hypercalcemia. Can J Surg. 2004, 47 (2): 144).

137. Strewler G.J., Stem P.H., Jacobs J.W. et al. Parathyroid hormonelike protein from human renal carcinoma cells structural and functional homology with parathyroid hormone // J Clin Invest.-1987; 80: 1803-1807.

138. Suva L.J., Winslow G.A., Wettenhall R.E. et al. A parathyroid hormone-related protein implicated in malignant hypercalcemia: cloning and expression // Science. 1987; 237: 893-896.

139. Sweeney C.J., Chen Y.-H., Carducci M., Liu G., Jarrard D.F., Eisenberger M., et al. Chemohormonal therapy in metastatic hormone-sensitive prostate cancer. New England Journal of Medicine. 2015; 373(8): 737-746. doi: 10.1056/NEJMoa1503747.

140. Theoleyre S., Wittrant Y., Tat S.K. et al. The molecular triad OPG/RANK/RANKL: involvement in the orchestration of pathophysiological bone remodeling. Cytokine Growth Factor Rev. 2004; 15: 457-475.

141. Thomas R., True L.D., Bassuk J.A., Lange P.H., Vessella R.L. Differential expression of osteonectin/SPARC during human prostate cancer progression. Clin Cancer Res. 2000; 6: 1140-9.

142. Tovar Sepulveda V.A., Falzon M. Regulation of PTH-related protein gene expression by vitamin D in PC-3 prostate cancer cells. Mol. Cell. Endocrinol. 2002; 190: 115-24. 
143. Tzelepi V., Zhang J., Lu J-F., Kleb B., Wu G., Wan X., et al. Modeling a lethal prostate cancer variant with small-cell carcinoma features. Clinical Cancer Research. 2012; 18(3): 666-677. doi: 10.1158/ 1078-0432.CCR-11-1867.

144. Videtic, G.M., Ago, C.T., Winquist, E.W. Hypercalcemia and carcinoma of the penis. Med Pediatr Oncol. 1997; 29: 576-577.

145. Wan X., Corn PG., Yang J., Palanisamy N., et al. Prostate cancer cell-stromal cell crosstalk via FGFR1 mediates antitumor activity of dovitinib in bone metastases. Science Translational Medicine. 2014; 6(252): 252ra122-252ra122. doi: 10.1126/scitranslmed.3009332.

146. Wang N., Docherty F.E., Brown H.K., Reeves K.J., et al. Prostate cancer cells preferentially home to osteoblast-rich areas in the early stages of bone metastasis: evidence from in vivo models. Journal of Bone and Mineral Research. 2014; 29(12): 2688-2696. doi: 10.1002/jbmr.2300

147. Weilbaecher K.N., Guise T.A., McCauley L.K. Cancer to bone: a fatal attraction. Nature Reviews // Cancer 2011; 11, 411-425.

148. Whang P.G., Schwarz E.M., Gamradt S.C., et al. The effects of RANK blockade and osteoclast depletion in a model of pure osteoblastic prostate cancer metastasis in bone. J Orthop Res. 2005; 23: 1475-1483.

149. Whitfield, J.F. Parathyroid hormone-related protein (PTHrP): an ancient string of cytokines with many known and still unknown functions. In Novel Aspects of PTHrP Physiopathology; Luparello, C., Ed.; Nova Science Publishers: New York, NY, USA, 2007; pp. 1-25.

150. Wright L.E., Guise, T.A. The Role of PTHrP in Skeletal Metastases and Hypercalcemia of Malignancy Clinic Rev Bone Miner Metab. 2014; 12:119.https://doi.org/10.1007/s12018-014-9160-y

151. Wu G.1., Iwamura M., di Sant'Agnese P.A. et al. Characterization of the cell-specific expres-sion of parathyroid hormone-related protein in normal and neoplastic prostate tissue // Urology. 1998; 51(5A Suppl): 110-120.

152. Wysolmerski J.J. Parathyroid hormone-related protein: An update // Clin.Endocrinol. Metab. 2012; 97: 2947-2956.

153. Wysolmerski J.J., Stewart A.F. The physiology of parathyroid hormone-related protein: An emerging role as a developmental factor // Annu Rev Physiol. 1998; 40: 431-460. 
154. Yan Z, Jin S., Wei Z. et al. Discoidin domain receptor 2 facilitates prostate cancer bone metastasis via regulating parathyroid hormone-related protein // Biochim Biophys Acta. 2014; 1842(9): 1350-63.

155. Yao A., Harada M., Matsueda S.et al. New epitope peptides derived from parathyroid hormone-related protein which have the capacity to induce prostate cancer-reactive cytotoxic T lymphocytes in HLA-A2+ prostate cancer patients // Prostate.2005; 62: 233-242.

156. Yilmaz M., Christofori G. EMT, the cytoskeleton, and cancer cell invasion // Cancer Metastasis Rev.2009; 28: 15-33.

157. Yonou H., Ochiai A., Goya M. et al. Intraosseous growth of human prostate cancer in implanted adult human bone: relationship of prostate cancer cells to osteoclasts in osteoblastic metastatic lesions. Prostate. 2004; 58: 406-413.

158. Zafeirakis A. Collagenous and non-collagenous biochemical markers of bone metastases from prostate cancer // HIPPOKRATIA. 2010, 14, 3: 164-169.

159. Zegarra-Moro O.L., Schmidt L.J., Huang H., Tindall D.J. Disruption of androgen receptor function inhibits proliferation of androgenrefractory prostate cancer cells // Cancer Res. 2002; 62: 1008-13.

160. Zhang H., Yu C., Dai J., et al. Parathyroid hormone-related protein inhibits DKK1 expression through c-Jun-mediated inhibition of $\beta$-catenin activation of the DKK1 promoter in prostate cancer // Oncogene. 2014; 33(19): 2464-77.

161. Zhang J., Dai J., Qi Y., et al. Osteoprotegerin inhibits prostate cancer-induced osteoclastogenesis and prevents prostate tumor growth in the bone. J Clin Invest. 2001; 107: 1235-1244.

162. Zhang J., Dai J., Yao Z., Lu Y., Dougall W., et al. Soluble receptor activator of nuclear factor kappaB Fc diminishes prostate cancer progression in bone. Cancer Res. 2003; 63: 7883-7890.

163. Курзанов А.Н., Быков И.М., Ледванов М.Ю. Паратиреоидный гормон-родственный белок - современные представления о структуpe, биохимических характеристиках и физиологической роли в организме // Современные проблемы науки и образования. - 2016. - № 6; URL: https://www.science-education.ru/ru/article/view?id=25543.

164. Медведев В.Л. Стрыгина Е.А., Курзанов А.Н. Паратиреоидный гормон-родственный белок и рак предстательной железы. Кубанский научный медицинский вестник. 2017; 162(1): 145-154. 


\section{ЗАКЛЮЧЕНИЕ}

Проведенный анализ литературы позволяет констатировать, что вопросы связанные с оценкой роли ПТГрП в развитии, фукционировании и возникновении различных заболеваний органов мочеполовой системы не могут считаться решенными. Это определяет необходимость продолжения и интенсификации разноплановых исследований участия ПТГрП в формировании морфофункционального статуса органов мочевыделительной и репродуктивной систем как при их номальном состоянии, так и при развитии патологических состояний. 


\section{СОКРАЩЕНИЯ И УСЯОВНЫЕ ОБОЗНАЧЕНИЯ}

Ang II - ангиотензин II.

ARF (acute renal failure) - острая почечная недостаточность.

Bax - PUMA - проапоптические факторы.

$\mathrm{Bcl}-\mathrm{XL}$ - противоапоптотический фактор.

BMP-2 - костный морфогенный белок 2.

BSA (bovine serum albumin) - бычий сывороточный альбумин.

CCL5 (C-C motif ligand 5) - цитокин, относится к группе CCхемокинов ( $\beta$-хемокинов), является наиболее мощным фактором хемотаксиса моноцитов в организме млекопитающих.

CDK-2 - циклинзависимая киназа-2.

Cyclin E - белок, относящийся к высококонсервативному семейству циклинов, функционирует в качестве регулирующей субъединицы CDK2-киназы способствуя временной координации митотических событий клеточного цикла путем фосфорилирования многочисленных белков.

COX-2 - фермент, участвующий в синтезе простагландинов, простациклинов и тромбоксанов. Экспрессируется макрофагами, синовиоцитами, фибробластами, гладкой сосудистой мускулатурой, хондроцитами и эндотелиальными клетками после индуцирования их цитокинами или факторами роста.

DDR2 (Discoidin Domain Receptor Tyrosine Kinase 2) - мембранный белок, фермент из надсемейства рецепторных тирозинкиназ, функционирует как поверхностный рецептор фибриллярного коллагена, регулирует клеточную дифференцировку, ремоделирование внеклеточного матрикса, клеточную миграцию и пролиферацию, необходим для нормального развития костной ткани.

DKK-1 (dickkopf-related protein 1) - белок, ингибирующий дифференцировку остеобластов, участвует в эмбриональном развитии, ингибируя сигнальный путь Wnt посредством снижения $\beta$-катенина.

DN (diabetic nephropathy) - диабетическая нефропатия.

ECM (extracellular matrix) - внеклеточный матрикс.

EGF (epidermal growth factor) - эпидермальный фактор роста.

EGFR (epidermal growth factor receptor) - рецептора эпидермального фактора роста. 
EMT (epithelial-mesenchymal transition) - эпителиально-мезенхимальный переход.

ERK (extracellular signal-regulated kinase) - киназа, регулируемая внеклеточными сигналами.

FN - фибронектин.

G-CSF (granulocyte-colony stimulating factor) - гранулоцитарный колониестимулирующий фактор.

G-ПCP - G-протеин-сопряженные рецепторы, (G-protein-coupled receptors, GPCRs), составляющие большое семейство трансмембранных рецепторов.

HG (high glucose) - высокое содержание глюкозы.

HIF- $1 \alpha$, HIF- $2 \alpha$ - гипоксически-индуцируемые факторы- $1 \alpha$ и $-2 \alpha$.

ICAM-1 (Inter-Cellular Adhesion Molecule 1) - молекула клеточной адгезии, присутствующая в низкой концентрации на мембранах лейкоцитов и эндотелиальных клеток.

IGF-I - инсулиноподобный фактор роста I.

IL-1 $\beta$ - интерлейкин-1 $\beta$.

IL-6 - интерлейкин-6.

I-TAC (CXCL11) (Interferon-inducible T-cell alpha chemoattractant) - цитокин, принадлежащий к семейству хемокинов CXC, который также называют интерферон-индуцируемым альфа-хемоаттрактантом Т-клеток, воздействует на клетки-мишени, взаимодействуя с рецептором хемокинов клеточной поверхности CXCR3.

L-NAME (L-Nitro-Arginine Methyl Ester) - L-нитроаргининметиловый эфир.

MAРК - митоген-активированные протеинкиназы.

MC (mesangial cells) - мезенгиальные клетки.

MCP-1 (monocyte chemoattractant protein 1) - моноцитарный хемоаттрактантный белок-1.

MIP-2 (Macrophage Inflammatory Proteins) - макрофагальный белок воспаления, один из представителей суперсемейства малых цитокинов, регулирующих иммунно-воспалительные реакцииЦитокин, является хемотаксическим для нейтрофилов.

NF-кB (nuclear factor кB) - ядерный фактор «каппа-би» - универсальный фактор транскрипции, контролирующий экспрессию генов, которые отвечают за процессы воспаления, иммунного ответа, апоптоза, клеточного цикла и пролиферацию клеток. 
ON (obstructive nephropathy) - обструктивная нефропатия.

OPG - остеопротегерин, представляет собой рецептор, конкурирующий с RANK за RANKL.

P27 - ингибитор фермента, который регулирует клеточный цикл путем ингибирования циклин-зависимой киназы-2 (CDK2).

p27Kip1 - ключевой компонент передачи ингибиторных сигналов, индуцируемых связыванием TGF-b со своими рецепторами.

p53 (белок р53) - транскрипционный фактор, регулирующий клеточный цикл. Увеличение синтеза белка р53 ведет к индукции синтеза внутриклеточного белка р21 - ингибитора циклин-зависимой киназы 1А.

PC3, DU-145 и LNCaP - культивируемые человеческие простатические клеточные линии.

PI3К - фосфоинозитид-3-киназа.

PTC (proximal tubule cells) - клетки проксимальных канальцев.

PTH1R - рецептор лигандов семейства паратиреоидного гормона первого типа.

RANK - рецептор-активатор ядерного траскрипционного факто-

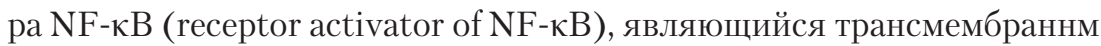
белком I типа.

RANK/RANKL/OPG - сигнальный путь является важнейшим регуляторным ме-ханизмом определяющим дифференцировку и активацию остеокластов в процессе ремоделирования костной ткани.

RANKL - лиганд рецептора активатора ядерного фактора-kB (Receptor activator of nuclear factor kappa-B ligand) - мембранный белок, цитокин семейства факторов некроза опухоли, играющий важную роль в метаболизме костной ткани, являясь одним из ключевых активаторов остеокластов.

RANTES (Regulated on Activation, Normal T-cell Expressed and Secreted) - хемокин, выделяемый Т-клетками при активации, хемоаттрактант для моноцитов и Т-клеток фенотипа CD4/CD45RO.

RCC (renal cell carcinoma) - почечноклеточная карцинома.

RUNX2 - фактор транскрипции.

SMAD - семейство структурно сходных белков, являющихся основными сигнальными трансдукторамими для рецепторов суперсемейства трансформирующего фактора роста бета (TGF-B), которые критически важны для регуляции развития и роста клеток. 
SOX2 - транскрипционный фактор, который контролирует экспрессию ряда генов, участвующих в эмбриональном развитии, критически важен для раннего эмбриогенеза и плюрипотентности эмбриональных стволовых клеток.

TARC (thymus and activation regulated chemokine) - тимус и peгулируемый активацией хемокин представляет собой CC-хемокин, который в основном экспрессируется в тимусе, индуцирует хемотаксис в Т-клетках, взаимодействует главным образом с рецептором CCR4 и в меньшей степени с рецептором CCR8.

TGF- $\beta 1$, TGF- $\beta 3$ - трансформирующие факторы роста- $\beta$.

TNF- $\alpha-$ фактор некроза опухоли- $\alpha$.

TP53 - ген, кодирующий белок р53.

VEGF (vascular endothelial growth factor) - фактор роста эндотелия сосудов VEGFR2 (receptors for vascular endothelial growth factor) - рецептор сосудистого эндотелиального фактора роста.

Wnt-сигнальный путь - один из важнейших внутриклеточных сигнальных путей, регулирующий эмбриогенез, дифференцировку клеток и развитие раковых опухолей.

$\alpha$-SMA ( $\alpha$-smooth muscle actin) - гладкомышечный $\alpha$-актин, является изоформой актина, которая преобладает в клетках гладких мышц сосудов и играет важную роль в фиброгенезе.

ГТС - гладкомышечная ткань сосудов.

ЕТ-1 - эндотелин-1.

MМР-2, -3,-7,-9, - матричные металлопротеиназы -2, -3,-7,-9.

мРНК - матричная рибонуклеиновая кислота - РНК, содержащая информацию о первичной структуре (аминокислотной последовательности) белков.

ОТ-ПЦР - полимеразная цепная реакция с обратной транскрипцией. ПТГ - паратиреоидный гормон.

ПТГрП - паратиреоидный гормон родственный протеин.

ПЦР-PB (RT-PCR) - полимеразная цепная реакция в реальном времени.

РПЖ - рак предстательной железы.

ФК - фолиевая кислота.

ХБП - хроническая болезнь почек.

ЦОГ-2 - циклооксигеназа 2. 
Медведев Владимир Леонидович

Ледванов Михаил Юрьевич

Курзанов Анатолий Николаевич

Быков Илья Михайлович

\title{
РОЛЬ ПАРАТГОРМОН-РОДСТВЕННОГО ПРОТЕИНА В РАЗВИТИИ, ФУНКЦИОНИРОВАНИИ И ПАТОЛОГИИ МОЧЕВЫДЕЛИТЕЛЬНОЙ И РЕПРОДУКТИВНОЙ СИСТЕМ
}

\author{
Монография
}

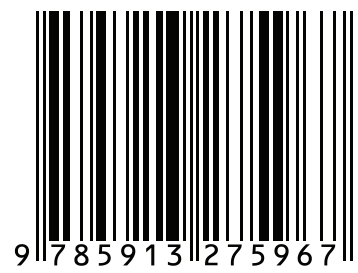

Технический редактор Кулакова Г.А.

Подписано в печать 24.09.2019

Бумага офсетная.

Гарнитура PeterburgC

Формат $60 \times 901 / 16$

Печать трафаретная. Печ. л. 12.

Тираж 500 экз. Заказ № 023-19.

Отпечатано в типографии ИД «Академия Естествознания», 440026, г. Пенза, ул. Лермонтова, 3 